JUAN RICARDO CRUZ-MOREIRA

\title{
INDUSTRIAL UPGRADING NAS CADEIAS PRODUTIVAS GLOBAIS: REFLEXÕES A PARTIR DAS INDÚSTRIAS TÊXTIL E DO VESTUÁRIO DE HONDURAS E DO BRASIL
}

Tese apresentada à Escola Politécnica da

Universidade de São Paulo para a obtenção do título de Doutor em Engenharia 


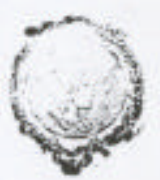

UNIVERSIDADE DE SÃO PAULO ESCOLA POLITÉCNICA

TERMO DE JULGAMENTO

$\mathrm{DE}$

\section{DEFESA DE TESE DE DOUTORADO}

Aos 31 dias do mês de julho de 2003, às 09:00 horas, no Departamento de Engenharia de Produçào da Escola Politécnica da Universidade de São Paulo, presente a Comissão Julgadora, Integrada pelos Senhores Professores Doutores Afonso Carlos Correa Eleury, orientador do candidato, Joåo Eduardo de Morais Pinto Furtado, Nadya Araújo Guimarães, João Amato Neto e Renato de Castro Garcia, iniciou-se a Defesa de Tese de Doutoramento do (a)Sr(a) JUAN RICARDO CRUZ-MOREIRA

Título da Tese: "INDUSTRIAL UPGRADING NAS CADEIAS PRODUTIVAS GLOBATS: REFLEXÕES A PARTIR DAS INDÚSTRIAS TÊXTIL E DO VESTUÁRIO DE HONDURAS E DO BRASIL"

Concluída a arguilção, procedeu-se ao julgamento na forma regulamentar, tendo a Comissão Julgadora considerado (a) candidato $(a)$ :

Prof. Dr. Afonso Carios Correa Fleury.........................( apnovedo ) Prof. Dr. Joāo Eduardo de Morais Pinto Furtado......( AP COJAD $D$ ) Prof ${ }^{\circ}$. Dr ${ }^{a}$. Nadya Araújo Guimarōes

Prof. Dr. João Amato Neto. ( $\triangle$ Priwape )

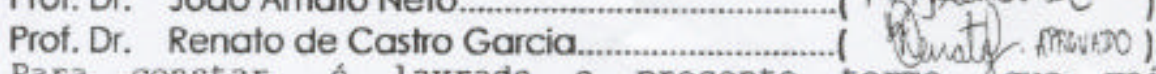
Para constar, é lavrado o presente termo, que vai assinado pela Comissão Julgadoră e pela Secretária de Pós-Graduaçåo.

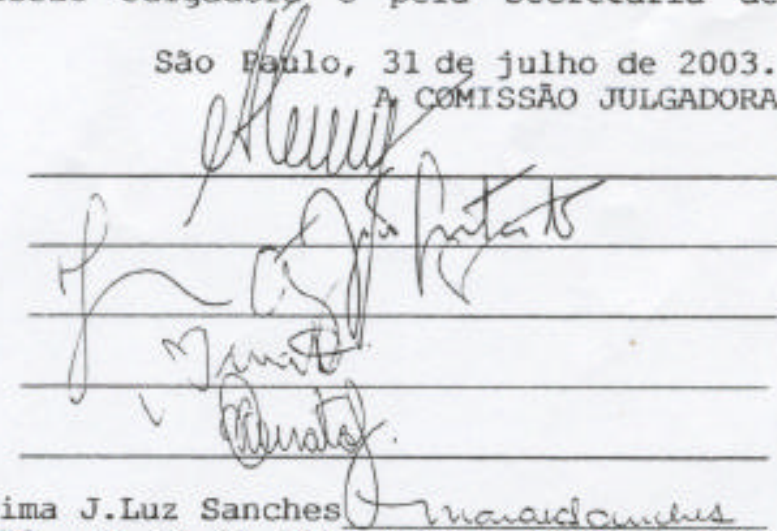

Secretária:Mara Fátima J.Luz Sanches Z wavacicunches Obs.: Resolução 4476 , de 17.09.1997 Altera dispositivos
do Regimento Geral da USP Art.109 - Imediatamente após o encerramento da argúiçâo da dissertação ou da tese cada examinador expressará seu julgamento en sessão secreta, considerando o candidato aprovado ou reprovado.

Homologado pela c.P.G. em reuniăo realizada $\frac{10.03}{23}$. 
JUAN RICARDO CRUZ-MOREIRA

\section{INDUSTRIAL UPGRADING NAS CADEIAS PRODUTIVAS GLOBAIS: REFLEXÕES A PARTIR DAS INDÚSTRIAS TÊXTIL E DO VESTUÁRIO DE HONDURAS E DO BRASIL}

Tese apresentada à Escola Politécnica da Universidade de São Paulo para a obtenção do título de Doutor em Engenharia

Área de Concentração: Engenharia de Produção

Orientador:

Prof. Dr. Afonso Carlos Correa Fleury 


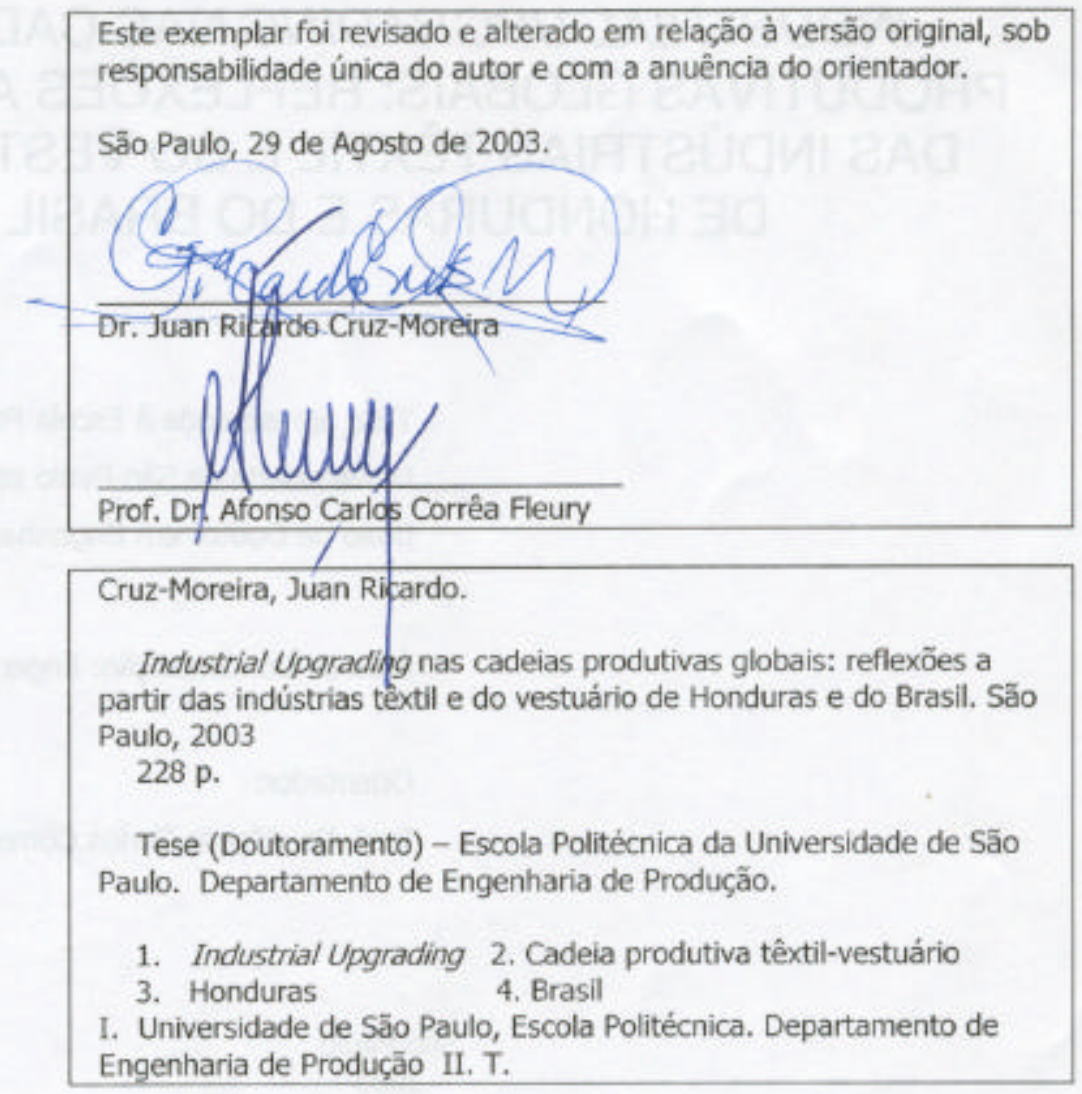




\section{Dedicatória}

\section{0 começo ...}

A Ricardo, M arta e Alicia, meus pais

A J uan e M aria meus avôs

In memoriam 


\section{Agradecimentos}

\section{...de uma longa viagem.}

E sta tese é o botim de uma longa viagem, indo de "Tegus" para "San Pedro" vi crescer, no lu gar dos canaviais, os edifícios das "maquilas" de roupas, parecia que o progresso e o emprego chegavam, quis saber se a moda hondurenha seria exportada. Que significavam todos aqueles empreendimentos para $H$ onduras e para os hondurenhos? Q uis saber mais e vim para $0 \mathrm{~B}$ rasil tentar entender... hoje quero agradecer aos companheiros (as) desta travessia:

A o professor A fonso $\mathrm{F}$ leury, da decolagem ao pouso final, obrigado por ajudar a decifrar os mapas, a aprumar 0 rumo e mirar 0 alvo, agradeço pelo estímulo, pelas oportunidades e pelas portas abertas, e pela amizade.

N o do D epartamento de E ngenharia de P rodução da U SP, vários (as) nos acompanharam em partes ou em todo o trajeto, gostaria de agradecer aos professores A mato e R enato pelas leituras, pelas discussões e pelas el ucubrações, às professoras $M$ arly, $M$ árcia e Selma, aos prof essores $L$ aerte, Shimizu, Plonsky, I srael, R eynaldo, M ario, M auro, H ugo, F ernando, R oberto e F austo, aos outros quepartilharam seu conhecimento e suas inquietudes acadêmicas. À s funcionárias (os) do D E P, a todas, mas especialmente à Olívia, à $D$ ona $A$ na eà $D$ ona Olga; ao pessoal da biblioteca da P rodução, em particular à $V$ era e ao $P$ ablo, na $V$ anzolini à Cristina, à $M$ ary eà $L$ ucilene, e no corredor à I da, à $M$ aria eà Priscila. A o 0 snir, à Cris e às meninas do Xerox pela sua colaboração, pelo estímulo e pela amizade.

Às minhas caríssimas e aos meus caros companheiros de aventura: Simone, A na, N eida, Thaise, Carmen, Sussana, M ar ta, Gabriela,M aria E lena, A lexandra, Carla, A ngélica, R osa, I eda, Sandra, à $M$ iss $B$ rasil , a D avi, Pledson, $M$ arvio, aos três Sergios, ao J orge e aos adidos Cris e Pí (o chinês), a todos os demais que partilharam as alegrias e desventuras desta travessia.

A lém de entender as CPTV s, a U SP me permitiu atuar, e sinto-me orgulhoso de ter participado do inicio do movimento de economia solidária; ao professor Paul Singer, aos (as) colegas das I TCP se especialmente às pessoas das cooperativas: Cooperbrilha, U nião Sul, Sete E los, O lho V ivo, Coopercaj, I tacooperarte, obrigado.

H ouve varias escalas até a chegada a este porto, na minha pequena escala em M ontreal, merci R egina et J ean $\mathrm{F}$ rançois. 
U ma grande eimportantíssima escala se fez no Socioolgy $D$ epartment na $D$ uke U niversty, obrigado ao professor $G$ ary $G$ ereffi, pelo convite para o estágio, pela partilha de suas idéias, pela participação em seus cursos e conferências e pelos contatos propiciados. A os professores e Tiryakian e Spenner, pelas atenções. A Theresa, Claudette, L isa, R ob e B ob, pelo apoio administrativo e de infraestrutura.

Ao Center for $L$ atin A merican and Caribbean Studies at D uke $U$ niversity, ao The Consortium in $\mathrm{L}$ atin A merican Studies at the $\mathrm{U}$ niversity of $\mathrm{N}$ orth Carolina at Chapel $\mathrm{Hill}$ and $\mathrm{D}$ uke $\mathrm{U}$ niversity $\mathrm{e}$ ao The Carolina and D uke W orking Group on "B razilian Culture: Contacts \& I ntertexts, pela acolhida.e a oportunidade de partilhar 0 meu trabalho, especialmente aos P rof.J ohn F rench, ao D r.Clements, à N altalie, J ulie, Bill e Sharon.

$\mathrm{N}$ a International H ouse a Lisa, Tom, B rian, também à $M$ ridu, e a todos (as)

N o T extile D eparment da N CSU, devo agradecer ao Prof. K ilduff e ao D r Grady pelo seu tempo e informações.

E aos outros amigos (as) viajantes que passavam por lá, N gamlamai, D eepa, e B innur, U Irich, L ee Cheng e I unus,. A os amigos (a) de H OL A, To all of you thanks a lot.

H ouve um breve retorno ao ponto de partida, em $H$ onduras. $O$ brigado à J ulieta, à $D$ ra. F rede e à $L$ ic. $M$ azier, a L icda. A rmida e especialemnte à M arta pelos contatos, aos Srs: N orman Garcia, J acobo $K$ attan, J esus Canahuati, M ario M artín, pelo seu tempo einformações, assim como a todos os executivos e funcionários da A H M A, F undação $F$ riedrich, $F$ undaci ón Covelo e das empresas e instituições que me forneceram informações, de forma especial à FID E e ao pessoal de sua excelente biblioteca. A J annette, $\mathrm{N}$ ana, $\mathrm{N}$ ury e $\mathrm{M}$ arbel pelo seu indispensável apoio na pesquisa de campo em H onduras, M uchas Gracias a todos y todas.

É jus agradecer aos patrocinadores deste percorrido: ao P ovo B rasileiro pelos estudos de doutorado na U SP e pela bolsa do CN P q, ao D epartamento de E ngenharia de Produção da U SP eà F undação $\checkmark$ anzolini, pelo apoio para os congressos e para o estágio na D uke, à D uK eU niverisity pela acolhida e toda sua infra-estrutura.

Q uando se chega ao final da viagem, vemos que entre todos acima nomeados muitos vão acompanhar nos em futuras caminhadas, M ônica, M arina \& Co. M abelita e suas meninas, E duardo, Regina e Sueli, eles vão comigo para outras viagens.

A os mais importantes que já faz em parte da minha caminhada desde sempre, meus irmãos (as) e suas famílias: O scar, Candy, A ndréa e 0 scarin, R osa, E duardo e A licia, M artha, D avid e Cátia, a Rapha.

A gradecimento imenso e infinito a Carlos el sabela e, ao K evin, por todo seu incondicional apoio e carinho.

\section{J uan Ricardo}

P.S.: À s minhas revisoras lingüísticas: Carmen, A dri e às R eginas (português), M ônica (I nglês) e Gabriela (espanhol) 


\section{Resumo}

O estudo apresenta uma análise sobre as trajetórias de Progressão Industrial em empresas/setores produtivos de países em desenvolvimento que participam de cadeias globais de formação de valor. Para isto são estudadas as cadeias produtivas do complexo têxtil-vestuário em Honduras e no Brasil. A análise usa as abordagens de Cadeias de Formação de Valor - Global Commodity Chains, assim como os modelos de Industrial Upgrading e a tipologia de Modernização Industrial. Estas abordagens julgaram-se complementares para a construção do referencial teórico do estudo.

Em Honduras a pesquisa focalizou o caso das empresas maquiladoras de roupa, no Brasil estudaram-se as cadeias lideradas por empresas brasileiras que atuam no mercado nacional e internacional. "Estudos de Casos Múltiplos" foi a metodologia escolhida para a realização da pesquisa de campo, em função da necessidade de estudar casos complexos em contextos diferenciados.

A reflexão final conclui que há diversos caminhos de inserção nas cadeias produtivas globais para as empresas dos países em desenvolvimento. Os avanços em termos Progressão Industrial para as empresas que participam dessas cadeias são limitados não só por aspectos tecnológicos ou de habilidades da força de trabalho local se não também pelas regulamentações do comércio internacional. Os acordos preferenciais e as barreiras comerciais são fundamentais para determinar as relações entre as empresas líderes e as subcontratadas, assim como a estrutura e a governance das cadeias produtivas globais. Mas também conclui-se que é possível uma inserção no mercado internacional menos dependente das empresas dos países centrais, que é através de cadeias lideradas por empresas dos países em desenvolvimento, utilizando para isso estratégias de inovação tecnológica, de gestão e em design e investimentos na valorização de marcas, atividades que geram maior valor agregado e permitem sua apropriação. 


\section{Resumen}

Este estudio presenta el análisis de las trayectorias de Avance Industrial en empresas y sectores productivos de países en desarrollo que participan de cadenas globales de formación de valor, para el cual se estudian las cadenas productivas del complejo industrial textil-vestido en Honduras e en Brasil. Para la construcción del marco teórico se utilizan los modelos de Cadenas de Formación de Valor - Global Commodity Chains, de Industrial Upgrading y la topología de Modernización Industrial.

En Honduras se investigaron las empresas maquiladoras de ropa y en Brasil las cadenas lideradas por empresas brasileñas que actúan en el mercado nacional y en el internacional. Se escogió la metodología de "Estudios de Casos Múltiples" para realizar la investigación de campo, debido a la necesidad de analizar casos complejos en diferentes contextos.

Se concluye finalmente que hay diversos caminos para la participación de las empresas de los países en desarrollo en cadenas productivas globales y que los avances en términos de Avance Industrial para estas empresas son limitados, no solo por aspectos tecnológicos o por la falta de habilidades de la fuerza laboral local, sino además por las leyes del comercio internacional. Los tratados de preferenciales y las barreras comerciales son determinantes fundamentales de las relaciones entre las empresas líderes y las subcontratadas, de la composición y de la estructura de poder en dichas cadenas productivas globales. Pero se concluye además, que hay posibilidades de participar en el mercado internacional de forma menos dependiente de las empresas de los países desarrollados y que esto puede ser alcanzado en cadenas productivas lideradas por empresas de los países en desarrollo, si estas implementan estrategias de innovación tecnológica y de gestión, con inversión en diseño y en la valorización de marcas originales pues son estas, pues son estas las actividades que generan mayor valor agregado y posibilitan su apropiación 


\section{Abstract}

The thesis is an analysis about the ways of the industrial upgrade in productive companies/sectors of developing countries which are included in global value chains.

It was selected the productive chains of the textile/apparel sector in Honduras and Brazil. The analysis uses the approaches of global value chains and global commodity as well as the patterns (models?) of industrial upgrading and the typology of industrial modernization. These approaches were considered important to the theoretical references of the study. In Honduras, the research focus was on the dressing "maquilas". In Brazil the focus was on those chains leaded by Brazilian companies acting both in the national and international market. It was chosen the multiple study case methodology to the field research due to the complexity of the cases in different environments.

It was concluded that there are several ways for a developing country company to be inserted in the productive global chains.

It is limited the development in terms of industrial upgrading for those companies which participate in these chains, not only by technological and manpower aspects but by the international commerce regulatory framework.

The commercial barriers and the preferential agreements are fundamental to determine the relations between the leading companies and the sub-contracted ones as well as the structure and the governance of the global productive chains.

Otherwise, the study shows that by using strategies as: technological and management innovation; design and investments in the valuation of trademarks, the companies from developing countries can get international markets because these strategies aggregate more value and facilitate their appropriation. 


\section{SUMÁRIO}

Lista de Tabelas

Lista de Figuras

Lista de Abreviaturas e Siglas

Resumo

Resumen

Abstract

\section{CAPITULO 1}

1. INTRODUÇÃO E OBJETIVOS .............................................................. 1

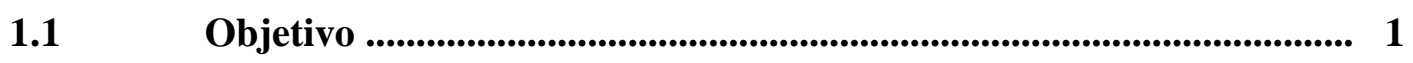

1.2 Contextualização ........................................................................... 2

1.2.1 O proces so de globalização produtiva ………...................................... 2

1.2.2 Foco e abordagem deste estudo ...................................................... 5

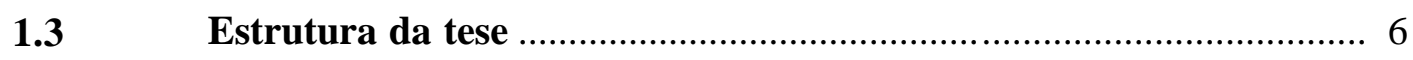

\section{CAPITULO 2}

2. AS INDÚSTRIAS TÊXTIL E DO VESTUÁRIO COMO CAMPO

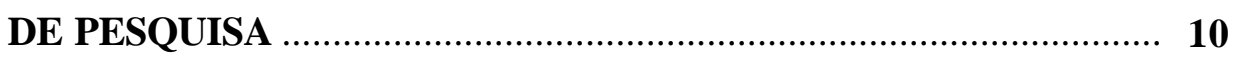

2.1 Por que as industrias têxtil e do vestuário são importantes para o estudo das cadeias produtivas globais? .......................................... $\quad 10$

2.1.1 A produção de roupas no mundo ...................................................... 12

2.1.2 Empresas emblemáticas da "nova" indústria do vestuário ..................... 17

2.2 A indústria do vestuário em Honduras, estratégias de industrialização e de geração de emprego baseadas na exportação.. 19

2.2.1 Maquilas e integração da produção entre as Américas do Norte e Central e o Caribe 
2.2.1.1 Evolução das maquilas no México e na América Central ...................... 25

2.2.2 A trajetória das maquiladoras hondurenhas ........................................ 34

2.2.2.1 A indústria do vestuário: motor da maquila em Honduras .................... 38

2.2.2.2 Quais são os produtos fabricados e qual o mercado da Indústria Hondurenha de Maquila de Roupas - IHMR? ..................................... 43

2.2.2.3 Valor agregado das exportações da Indústria Hondurenha de Maquila de Roupas - IHMR ....................................................................... 50

2.2.2.4 Produtividade, emprego e salários na Indústria Hondurenha de Maquila de Roupas - IHMR .................................................................. 51

2.2.2.5 Situação da mulher trabalhadora nas maquilas hondurenhas ................ 54

2.2.2.6 Ambiente institucional da Indústria Hondurenha de Maquila de Roupas

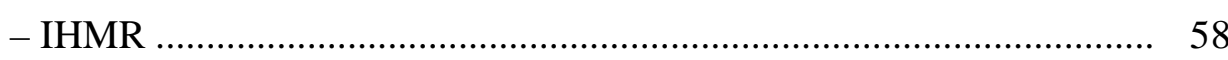

2.2.3 Problemática da Progressão Industrial na Indústria Hondurenha de Maquila de Roupas - IHMR ...................................................... 62

2.3 As cadeias de produção têxtil-vestuário brasileiras .......................... 63

2.3.1 Processo de formação da indústria do vestuário no Brasil ..................... 65

2.3.2 A década de 1990 e a abertura de mercado..........................................69 69

2.3.3 A participação da cadeia têxtil-vestuário na indústria nacional

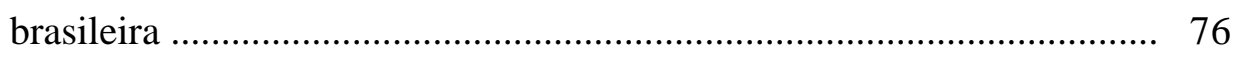

2.3.4 A participação dos têxteis e vestuário brasileiros no Mundo .................. 78

2.3.5 Estrutura empresarial das cadeias têxtil-vestuário brasileiras ................ 83

2.3.5.1 O elo das produtoras de fibras e as firmas integrada s à montante ........... 84

2.3.5.2 O elo do meio: empresas produtoras de tecidos e de roupas ................... 88

2.3.5.3 O elo da Comercialização ................................................................. 89

2.3.5.4 Empresas estrangeiras no Brasil .......................................................... 90

2.3.5.5 Ambiente Institucional das Cadeias Produtivas Têxtil-Vestuário CPTV Brasileiras ...................................................................... 92

2.3.5.6 Estratégias para Progressão Industrial e competitividade nas Cadeias Produtiva Têxtil-Vestuário - CPTV brasileiras. 


\section{CAPITULO 3}

3. AS ABORDAGENS DE CADEIAS DE VALOR E

TRAJETÓRIAS DE PROGRESSÃO INDUSTRIAL ......................... 95

G.1 Globalização produtiva .................................................................. 95

3.1.1 Relocalização internacional da produção............................................. 96

3.1.2 Subcontratação e Manufatura Triangular Asiática .................................. 98

3.2 Cadeias Globais de Formação de Valor ............................................ 102

3.2.1 Antecedentes ............................................................................. 102

3.2.2 Cadeias Globais de Produção - Global Commodity Chains - GCC ........ 104

3.2.3 As variáveis do modelo de Global Commodity Chains - GCC .............. 109

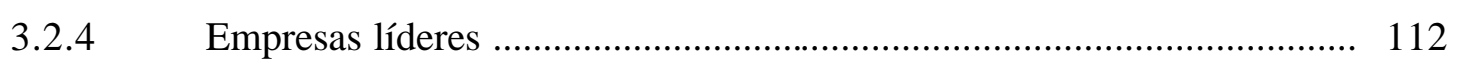

3.2.5 Governance nas cadeias lideradas pelos compradores ......................... 113

3.2.5.1 Produtores com Marca (Branded Manufacturers) ................................. 114

3.2.5.2 Varejistas (Retailers) ...................................................................... 114

3.2.5.3 Comercializadores com Marca (Marketers) ......................................... 115

3.3 Progressão Industrial (Industrial Upgrading) e Modernização

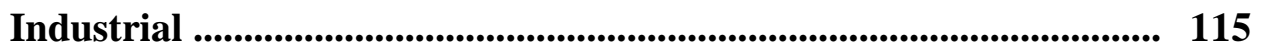

3.3.1 O conceito de Progressão Industrial ................................................... 116

3.3.2 Progressão Industrial segundo Humphrey et Schmitz ........................... 117

3.3.3 Progressão Industrial e seqüência de Modernização Industrial segundo Gereffi, fundamentada nas trajetórias de empresas dos Tigres Asiáticos 119

3.3.4 Progressão Industrial e Modernização Industrial, proposições de compatibilização de Kaplinsky et Morris .............................................. 126

3.3.5 Uma avaliação crítica da capacidade dos modelos apresentados ........... 127

3.3.5.1 Trajetórias das empresas lideres dos países desenvolvidos nas Cadeias Produtivas Têxtil-Vestuário - CPTV globais ....................................... 133

3.3.5.1.1 Trajetória das empresas Produtoras com Marca ..................................... 133

3.3.5.1.2 Trajetória das empresas Varejistas .................................................. 135

3.3.5.1.3 Trajetória das empresas Comercializadoras com Marca ........................ 137 
3.3.5.2 Trajetórias das empresas dos países de recente industrialização na Ásia e no Caribe

3.3.5.2.1 Trajetórias das empresas asiáticas ........................................................ 139

3.3.5.2.2 Trajetórias das empresas Mexicanas e de países da Bacia do Caribe ..... 141

A proposição de um novo modelo .............................................................. 146

As perguntas da pesquisa .............................................................. 148

\section{CAPITULO 4}

4. A PESQUISA DE CAMPO - METODOLOGIA …..................... 149

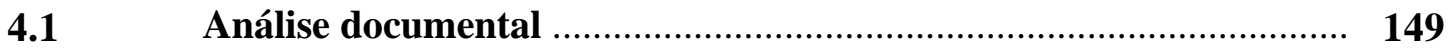

4.2 $O$ método da pesquisa de campo em função das perguntas do

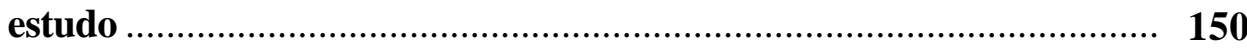

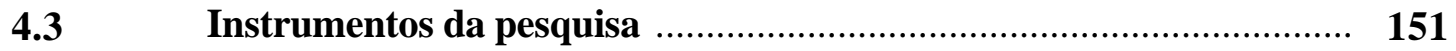

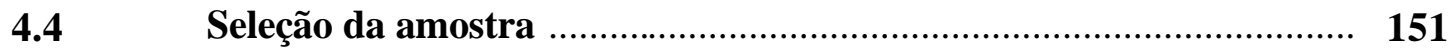

4.4.1 Amostra e realização da pesquisa em Honduras .................................... 152

4.4.2 A pesquisa de campo e resultados no Brasil ........................................ 155

\section{CAPÍtULO 5}

5. RESULTADOS DA PESQUISA DE CAMPO E ANÁLISE DOS CASOS .................................................................................. 157

5.1 Análise das trajetórias das empresas hondurenhas sob a abordagem de Progressão Industrial ................................................... 158

5.1.1 Trajetórias das empresas maquiladoras em Honduras .......................... 158

5.1.1.1 As trajetórias das maquiladoras de capital nacional ............................. 158

5.1.1.2 Trajetórias das maquiladoras de capital estrangeiro .............................. 163

5.1.2 Empresas atuando no mercado nacional hondurenho ............................. 164

5.1.2.1 Empresas nacionais Produtoras com Marca ................................................ 164

5.1.2.2 As empresas de confecção do setor informal hondurenho ...................... 165

5.1.2.3 Investimento das empresas nacionais na maquila hondurenha .............. 167

5.1.2.4 Varejo de roupas em Honduras ............................................................ 168 
5.1.3 Competências Progressão Industrial na Indústria Hondurenha de Maquiladora de Roupas - IHMR

5.2 Análise das empresas e cadeias produtivas têxtil-vestuárioo CPTV brasileiras ................................................................................................. 171

5.2.1 CPTV brasileiras e empresas líderes de acordo ao modelo de Global Commodity Chains - GCC

5.2.1.1 As empresas Produtoras com Marca nas CPTV brasileiras ................... 171

5.2.1.2 Cadeias produtivas lideradas pelas Comercializadoras com Marca ........ 174

5.2.1.3 O varejo de roupas no Brasil .......................................................... 175

5.2.2 Trajetórias das empresas brasileiras sob a abordagem de Progressão Industrial

5.2.2.1 Empresas produtoras de vestuário 178

5.2.2.2 Trajetória das empresas Comercializadoras com Marca ....................... 182

5.2.2.3 Trajetória dos Varejistas ................................................................ 183

5.2.3 Aprendizado e ganho de competências no processo de Progressão Industrial das Cadeias de Produção Têxtil-Vestuário - CPTV brasileiras

5.3 Comparação, analise e conclusões a respeito das Cadeias Produtivas Têxtil-Vestuário - CPTV em ambos os países

5.3.1 Produtos, mercado e investimento internacional das empresas hondurenhas e brasileiras

5.3.2 Estrutura e governance das cadeias em que estão inseridas as maquiladoras hondurenhas e as empresas brasileiras

5.3.3 Considerações em relação ao progresso industrial das empresas hondurenhas e brasileiras nas Cadeias Produtivas Têxtil-VestuárioCPTV

5.3.4 Síntese das Trajetórias de Progressão Industrial das empresas das CPTV de Honduras e do Brasil

5.4 Modelo revisitado nas Cadeias Produtivas Têxtil-Vestuário

5.4.1 As trajetórias de Modernização Industrial e de Progressão Industrial baseadas nos casos analisados 


\section{CAPITULO 6}

6. CONSIDERAÇÕES FINAIS E CONCLUSÕES

6.1 Síntese do trabalho desenvolvido e conclusões ................................ 207

6.2 Modelo genérico _............................................................................... 212

6.3 Limitações do estudo _...................................................................... 213

6.4 Possibilidades de generalização para outras cadeias e proposta de estudos complementares no futuro

REFERÊNCIAS BIBLIOGRÁFICAS

\section{APÊNDICES}

A.1 Questionário aplicado no Brasil

A.2 Questionário aplicado em Honduras 


\section{LISTA DE TABELAS}

Tabela 2.1 - Participação e variação percentual das exportações ao mercado dos países industrializados, 1985-1998 (Países selecionados)

Tabela 2.2 - Tipos de maquiladoras por regime de preferências tarifárias em EUA e por atividades realizadas 28

Tabela 2.3 - Investimento internacional na maquila centro-americana por número e \% de empresas /país de origem (1996)

Tabela 2.4 - América Central e México, perdas e ganhos de acordo com a participação constante de mercado nos 20 primeiros itens de confecção importados pelos Estados Unidos, 1992-1995 (em milhões de US\$ dólares) 33

Tabela 2.5 - Principais incentivos por Regime de Exportação.

Tabela 2.6 - Origem do capital das empresas maquiladoras em Honduras (1994, 1997, 2000, 2001, participação \% e Variação)

Tabela 2.7 - Investimento dos Países Asiáticos na IHMR por número de empresas 42

Tabela 2.8 - Produtos fabricados na IHMR 44

Tabela 2.9 - Diversidade de produtos ou de serviços diretamente ligada ao processo produtivo, por empresas agrupadas segundo país de origem do capital na IHMR (2000/2001) 45

Tabela 2.10- Produtos por país de origem das empresas maquiladoras em Honduras (2000-2001) 46

Tabela 2.11- Exportações de têxteis e vestuário hondurenhos a Estados Unidos, (1983-2001) 49

Tabela 2.12- Exportações da IHMR a Estados Unidos (1994-2001) 49

Tabela 2.13- Balanço comercial têxtil e de vestuário hondurenho (US\$ milhões) 
Tabela 2.14- Evolução do valor agregado da maquila gerado no país

(US\$ milhões/ ano)

Tabela 2.15- Emprego gerado pela maquila na década de 1990

(No. de pessoas)

Tabela 2.16- Evolução dos salários nas maquilas de roupa hondurenhas (US\$/ano)

Tabela 2.17- Produção das empresas maquiladoras sob os regimes de ZIP e

ZOLI em Honduras 1990 - 2000 p/

(Em milhões de Lempiras à época).

Tabela 2.18- Distribuição por gênero na maquila hondurenha ............................ 54

Tabela 2.19- Requerimentos Trabalhistas na IHMR ............................................. 58

Tabela 2.20- Setores predominantes nas ZIP e ZOLI (2000) …............................ 59

Tabela 2.21- Evolução da participação das regiões na produção da cadeia têxtil-vestuário no Brasil (1990 a 2000)

Tabela 2.22- Produção e importação de máquinas têxteis no Brasil (milhões de dólares) ................................................................... 75

Tabe la 2.23- Estrutura empresarial da CPTV brasileira ..................................... 77

Tabela 2.24- Participação percentual da CPTV e sus principais elos no total das cadeias produtivas brasileiras

Tabela 2.25- Distribuição do número de estabelecimentos, número médio de empregados e remuneração media na cadeia têxtil/confecções brasileira em 2001 78

Tabela 226- Participação brasileira no mercado de têxteis e de confecções 79

Tabela 2.27- Importações e exportações do têxtil-vestuário brasileiro detalhado por segmentos $(1990$ e 1998) .......................................... 80

Tabela 2.28- Importações da cadeia têxtil-vestuário brasileira (2001 e 2002) ....... 82

Tabela 2.29_ Exportações da cadeia têxtil-vestuário (2001 e 2002) ...................... 82

Tabela 2.30- Balança comercial na CPTV brasileira 2001-2002 (US\$1000 FOB) 83

Tabela 2.31- Produção de fibras têxteis no Brasil, 1985/2000 (mil ton) ................ 86 
Tabela 4.1- Distribuição das empresas constituintes da amostra em Honduras ... 153

Tabela 4.2- Classificação das empresas da amostra em Honduras de acordo às categorias de Modernização Industrial ............................................ 154

Tabela 4.3- Distribuição das empresas constituintes da amostra no Brasil .......... 155

Tabela 4.4 Classificação das empresas da amostra no Brasil, de acordo às categorias de Modernização Industrial ......................................... 156 


\section{LISTA DE FIGURAS}

Figura 1 - Distribuição geográfica das operações das cadeias produtivas têxtil-vestuário estudadas.

Figura $2.1-\quad$ Cadeia produtiva têxtil-vestuário 13

Figura 3.1 - Produção triangular 101

Figura 3.2 - Cadeias lideradas pelos produtores (Producer Driven Chains) ....... 107

Figura 3.3 - Cadeias lideradas pelos compradores (Buyer Driven Chains) ......... 108

Figura 3.4 - Trajetórias de Modernização Industrial das empresas dos Tigres Asiáticos 125

Figura 3.5 - Comparação entre Trajetórias de Progressão Industrial e estágios de Modernização Industrial das empresas dos países de industrialização recente 126

Figura 3.6 - Atividades características das empresas nas diferentes posições da Tipologia de Modernização Industrial 128

Figura 3.7 - Posicionamento de empresas de pa íses selecionados em algumas cadeias de formação de valor típicas da indústria do vestuário

Figura 3.8 - Posições na tipologia de Modernização Industrial das empresas dos países desenvolvidos, líderes nas CPTV

Figura 3.9 - Trajetórias de Modernização Industrial das empresas dos países de industrialização recente; posições alcançadas e perspectivas de acordo a países ou regiões

Figura 3.10 - Trajetória das empresas globais Produtoras com Marca 134

Figura 3.11 - Trajetória das empresas globais Varejistas com Marca 136

Figura 3.12 - Trajetória das empresas globais Comercializadoras com Marca ..... 138

Figura 3.13 - Trajetória das empresas dos NICs Asiáticos ................................... 140

Figura 3.14 - Trajetória das empresas maquiladoras mexicanas ......................... 143 
Figura 3.15 - Trajetória das empresas maquiladoras dos países da IBC

Figura 3.16 - Trajetórias de Progressão Industrial e Modernização Industrial ...... 148

Figura 5.1 - Empresa fornecedora de pacote comple to inclusive design ........... 160

Figura 5.2 - Empresa fornecedora de tecidos e de vestuário - pacote completo . 162

Figura 5.3 - $\quad$ Empresa maquiladora iniciante ...................................................... 162

Figura 5.4 - Empresa Asiática fornecedora de tecidos e de vestuário - pacote completo ............................................................................ 163

Figura 5.5 - Empresas nacionais produtoras com Marca .................................. 165

Figura 5.6 - Microempresas do setor informal que florescem em torno da

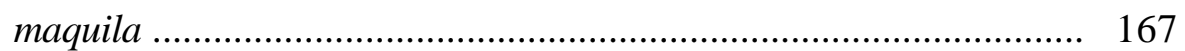

Figura 5.7 - Trasbordamentos de capital nacional para a maquila ..................... 168

Figura 5.8 - Composição do varejo interno hondurenho .................................... 169

Figura 5.9 - Competências das maquiladoras hondurenhas no início da década de 1980 e início do Séc. XXI ....................................................... 170

Figura 5.10 - Produtoras de vestuário com Marca integradas verticalmente ....... 178

Figura 5.11 - Produtores de vestuário com Marca ................................................... 179

Figura 5.12- Fornecedores de vestuário ODM atacadistas ................................. 180

Figura 5.13- Produtoras de vestuário ODM ..................................................... 180

Figura 5.14 - Comercializadoras com Marca …................................................... 183

Figura 5.15 - Varejistas com Marca ................................................................... 184

Figura 5.16 - Grandes Varejistas ............................................................... 184

Figura 5.17 - Varejistas com Marca com estratégias de serviços financeiros ....... 186

Figura 5.18 - Competências das empresas brasileiras coletivamente antes e depois da reestruturação produtiva da década de 1990 ..................... 186

Figura 5.19 - Síntese das Trajetórias de Modernização Industrial das empresas de Honduras e Brasil ................................................................... 199

Figura 5.20 - Novo modelo de Trajetórias de Industrial Upgrading e Modernização Industrial

Figura 6.1 - Trajetórias de Progressão Industrial e Modelos de Relações Interempresariais nas Cadeias Produtivas Globais 


\section{LISTA DE ABREVIATURAS E SIGLAS}

\begin{tabular}{|c|c|}
\hline ABIMAQ & - Associação Brasileira da Indústria de Maquinas e Equipamentos \\
\hline ABIT & - Associação Brasileira da Indústria Têxtil e de Confecção \\
\hline \multirow[t]{2}{*}{ ABRAFAS } & - Associação Brasileira de Produtores de Fibras Artificiais e \\
\hline & Sintéticas \\
\hline ABRAVEST & - Associação Brasileira do Vestuário \\
\hline $\mathrm{AC}$ & - América Central \\
\hline AFIPOL & - Associação Brasileira dos Produtores de Fibras Poliolefínicas \\
\hline \multirow[t]{2}{*}{ AHMA } & - Asociación Hondurenha de Maquiladores - Apparel Honduran \\
\hline & Manufacturers Association \\
\hline $\mathrm{AMF}$ & - Acordo Multifibras \\
\hline ASEAN & - Association of Southeast Asian Nations \\
\hline ATC & - Acordo dos Têxteis e Vestuário - Agreement of Textiles \& Clothing \\
\hline $\mathrm{B} 2 \mathrm{~B}$ & - Business-to-Business \\
\hline $\mathrm{BCH}$ & - Banco Central de Honduras \\
\hline BDC & - Buyer Driven Chain \\
\hline BNDES & - Banco Nacional de Desenvolvimento Econômico e Social (Brasil) \\
\hline BR-N & - Brandnamed Retailers - Nacionais \\
\hline $\mathrm{C} \& \mathrm{D}$ & - Competências em Comercialização e Distribuição próprias \\
\hline $\mathrm{CAD} / \mathrm{CAM}$ & - Computer Aided Design/Computer Aided Manufacturing \\
\hline $\mathrm{CCA}$ & - Corte, Costura e Acabamento \\
\hline $\mathrm{CDC}$ & - Crédito Direto ao Consumidor \\
\hline \multirow[t]{2}{*}{ CETIQT } & - Centro de Tecnologia para a Indústria Química e Têxtil do \\
\hline & SENAI-RJ \\
\hline CETVEST & - Centros de Tecnologia Têxtil e de Vestuário do SENAI-SP \\
\hline CGPV & - Cadeias Globais de Produção de Vestuário \\
\hline CONAB & - Companhia Nacional de Abastecimento \\
\hline CPTV & - Cadeia Produtiva Têxtil Vestuário \\
\hline CUT & - Central Única dos Trabalhadores \\
\hline EDI & - Electronic Data Interchange \\
\hline
\end{tabular}




\begin{tabular}{|c|c|}
\hline EN & - Empresas Nacionais \\
\hline ENP & - Empresa Nacional Portuaria \\
\hline EU & - European Union \\
\hline EUA & - Estados Unidos da América \\
\hline FEI & - Faculdade de Engenharia Industrial \\
\hline FIDE & - Fundación para la Inversión y Desarrollo de las Exportaciones \\
\hline FMI & - Fundo Monetário Internacional \\
\hline GB & - Global Buyers \\
\hline GCC & - Global Commodity Chains \\
\hline GEXPRONT & - Gremial de Exportadores de Productos no Tradicionales \\
\hline GS & - Global Supplier \\
\hline GVC & - Global Value Chains \\
\hline HD & - Hawaiian Dreams \\
\hline IBC & - Iniciativa para a Bacia do Caribe \\
\hline IBGE & - Instituto Brasileiro de Geografia e Estatística \\
\hline IBQP-PR & - Instituto Brasileiro de Qualidade e Produtividade no Paraná \\
\hline IDS & - Institute for Development Studies \\
\hline IED & - Investimento Externo Direto \\
\hline IEMI & - Instituto de Estudos e Marketing Industrial \\
\hline IHMR & - Indústria Hondurenha de Maquila de Roupas \\
\hline IHSS & - Instituto Hondureño de Seguridad Social \\
\hline IME & - Industria Maquiladora de Exportación \\
\hline INFOP & - Instituto Nacional de Formación Profesional \\
\hline IR & - Imposto sobre a Renda \\
\hline ISI & - Industrialização por Substituição de Importações \\
\hline IT & - Information Technology \\
\hline ITCP & - Incubadora Tecnológica de Cooperativas Populares \\
\hline ITMF & - International Textile Manufacturers Federation \\
\hline JIT & - Just-in-Time \\
\hline MBA & - Master in Business Administration \\
\hline MDO & - Mão-de-Obra \\
\hline
\end{tabular}




\begin{tabular}{|c|c|}
\hline MEC & - Ministério da Educação e do Desporto \\
\hline \multicolumn{2}{|c|}{ MERCOMUN - Mercado Comum Centroamericano } \\
\hline MERCOSUL & - Mercado Comum do Cone Sul \\
\hline $\mathrm{MNC}$ & - Multinational Companies \\
\hline NAFTA & - North American Free Trade Agreement \\
\hline NIC & - New Industrialized Countries \\
\hline NIE & - Newly Industrialized Economies \\
\hline OBM & - Original Brand Name Manufacturing / Own Brand Manufacturers \\
\hline OCDE & - Organization for Economic Cooperation and Development \\
\hline ODM & - Original Design Manufacturing \\
\hline OEA & - Original Equipment Assembly \\
\hline OEM & - Original Equipment Manufacturer \\
\hline OIT & - Organização Internacional do Trabalho \\
\hline OMC & - Organização Mundial do Comércio \\
\hline ONG & - Organização não Governamental \\
\hline ONU & - Organização das Nações Unidas \\
\hline $\mathrm{P} \& \mathrm{D}$ & - Pesquisa e Desenvolvimento \\
\hline PDC & - Producer Driven Chains \\
\hline PIB & - Produto Interno Bruto \\
\hline PIME & - Pequena e Média Empresa \\
\hline POY & - Partly Oriented Yarns \\
\hline PROCOMER & - Promotora del Comercio Exterior (Costa Rica) \\
\hline RAIS & - Relação Anual de Informações Sociais \\
\hline RIT & - Regimen de Importación Temporaria \\
\hline $\mathrm{SAC}$ & - Sistema Arancelario Centroamericano \\
\hline $\mathrm{SCM}$ & - Supply Chain Management \\
\hline SECEX & - Secretaria de Comércio Exterior \\
\hline SENAI & - Serviço Nacional de Aprendizagem Industrial \\
\hline SGP & - Sistema Geral de Preferências \\
\hline SPFW & - São Paulo Fashion Week \\
\hline TI & - Tecnologia da Informação \\
\hline
\end{tabular}


TNC - Transnational Companies

USAID - - US Agency for International Development

USITC - US International Trade Commission

ZIP - Zonas Industriales de Procesamiento para la Exportación

ZOLI - Zona Libre

ZPE - Zona Processadora para a Exportação 


\section{CAPÍTULO 1}

\section{INTRODUÇÃO E OBJETIVOS}

\subsection{Objetivo}

O objetivo deste estudo é analisar como ocorre o processo de Progressão Industrial em empresas/setores produtivos que participam de cadeias globais de formação de valor.

A análise parte de um estudo sobre as cadeias produtivas do complexo têxtil-vestuário, setores considerados tradicionais, mas que nos últimos tempos têm trilhado processos de reestruturação produtiva tanto no interior das empresas como no contexto internacional, levando à formação de cadeias globais de produção ou formação de valor.

A abordagem de Industrial Upgrading se fundamenta no estudo das trajetórias das empresas líderes de países que realizaram sua reestruturação industrial com estratégias de exportação, como foi o caso dos mais conhecidos NICs Asiáticos.

Em português, utilizar-se-á o termo "Progressão Industrial" para traduzir Industrial Upgrading, considerando-o adequado para definir os estágios e trajetórias que percorrem as empresas atuantes nas cadeias de formação de valor, por ser um conceito que expressa as idéias de progresso, avanço e desenvolvimento industrial relacionadas a esse processo. 
Ao analisar os casos de Honduras e Brasil, cujas empresas se inserem posteriormente nas cadeias de produção globais, trilhando trajetórias diferentes das empresas asiáticas, pretende-se discutir se é possível e quais são os graus ou estágios de Progressão Industrial que estas empresas podem alcançar.

O estudo das cadeias produtivas das indústrias têxtil e de vestuário pode gerar insumos para a análise da inserção e posicionamento de empresas de outros setores industriais em países em desenvolvimento.

Esta questão de relevância acadêmica é também importante no atual contexto em que se retomam as discussões sobre Políticas Industriais e de Desenvolvimento Social e Econômico.

\subsection{Contextualização}

\subsubsection{O processo de globalização produtiva}

Segundo Bauman (1996), no final da cécada de 90, o mundo entrou na sua terceira etapa do processo de globalização. Esta etapa levoua uma nova distribuição internacional da produção, do trabalho e também da comercialização globais.

A primeira etapa teria sido a da globalização financeira iniciada nos anos 70 , com a desregulamentação dos mercados financeiros, sendo potencializada pelo avanço das tecnologias da informação.

O segundo momento foi o da globalização comercial, intensificado nos anos 80 pela redução das barreiras nacionais ao comé rcio internacional e pelos novos equipamentos e tecnologias de transporte., o que fundamentalmente implica a passagem de um regime de "mercado vendedor" para o de "mercado comprador". Na medida em que o mercado 
tornou-se comprador, quem passou a "ditar as regras" foram os clientes e consumidores. As empresas passaram a "orientar-se para o cliente" e o movimento da qualidade emergiu como um dos balizadores do desenvolvimento empresarial (Fleury et Fleury, 2000).

O novo regime de mercado, a globalização produtiva e a chegada de uma economia baseada em conhecimento levam as empresas a buscar novas formas de organização e gestão da produção.

Inicialmente as empresas dos países industrializados transferem plantas produtivas não só para outras regiões - muitas vezes dentro dos limites nacionais, mas também, e principalmente, para países em desenvolvimento - em busca de seus mercados e também de vantagens comparativas, como recursos naturais ou custos do trabalho.

Alguns dos países em desenvolvimento utilizam estratégias de Desenvolvimento Econômico, baseadas na estratégia de Industrialização por Substituição de Importações ISI e estimulam os Investimentos Externos Diretos - IED. Essas estratégias e investimentos coincidiram com as estratégias de internacionalização das grandes empresas dos países industrializados que se materializaram com a implantação de plantas produtivas subsidiárias, pela subcontratação de operações e/ou a aquisição de insumos ou componentes em outros países.

Os países asiáticos utilizaram estratégias de industrialização direcionadas para a exportação, ao mesmo tempo em que aumentava o poder aquisitivo dos consumidores nos países industrializados.

A transformação dos processos de produção na fábrica desenvolvidos pela Toyota para a eliminação de tempo e desperdícios e para fazer a produção mais flexível e eficiente, como o uso do Kanban, que paulatinamente levou ao desenvolvimento do Just-In-Time - JIT, faz parte desta revolução. No momento em que houve a necessidade de se 
organizar como cadeia de suprimentos, surgiu imperativamente o aperfeiçoamento dos métodos aprendidos e a implantação do JIT externo.

Watanabe $(1971,1978)$ descreve a importância dos processos de descentralização e subcontratação no Japão e em outros países asiáticos nos processos de industrialização. A subcontratação de parte da produção dos bens completos ou de parte dos processos ou insumos de produção constituiu uma das primeiras ações coletivas de grupos de empresas incentivadas pelos governos locais, regionais e nacionais, assim como por grupos de empresas.

Essa estratégia possibilitou o aprendizado industrial, a aquisição de tecnologia e o knowhow de gestão, e proporcionou também o conhecimento de mercados necessários para a inserção dos produtos japoneses no comércio internacional.

A partir daí e das demais inovações asiáticas, conceitos como gestão da cadeia de fornecedores, Supply Chain Managemen - SCM e logística, cadeias de produção e comercialização, cadeias de agregação de valor, competências essenciais e eficiência coletiva, começam a se definir.

Nesse marco conceitual, a formação de cadeias produtivas pode ser analisada através de diversas abordagens conceituais ou modelos: a primeira tem raízes no modelo japonês dos keiretsu. A organização vertical e centralizada dos Keiretsu (Fleury et Fleury, 1995, Amato, 1993.), além de permitir o desenvolvimento de capacidades para a inserção internacional das suas empresas constituintes, representa um exemplo das "aglomerações locais", denominados como Clusters nos Estados Unidos e como Distritos Industriais na Itália (Amato 1993, Porter 1990, Piore et Sabel, 1984).

Tanto as redes e cadeias produtivas globais como os agrupamentos regionais ou locais de empresas baseiam sua forma de produção na gestão eficiente de cadeias de fornecedores. Estas redes de suprimento compreendem cadeias, através das quais bens e 
serviços fluem das fontes originais aos consumidores finais (Harland, 1996). Fleury et Fleury (2002) chamam-nas de redes inter organizacionais e consistem de "entidades interconectadas, cujo propósito primário é a obtenção, uso e transformação de recursos para prover pacotes de bens e serviços".

\subsubsection{Foco e abordagem deste estudo}

Este estudo utiliza, para descrever e modelar o objeto de estudo, a abordagem de Cadeias de Formação de Valor, metodologia originalmente desenvolvida e consolidada como Global Commodity Chains - GCC, assim:

"Uma cadeia global de produção consiste em elos ou operações que compreendem pontos pivotais nos processos de produção, fornecimento de matérias primas, produção e exportação; cruzando todo o espectro de atividades da economia mundial. Cada elo é por si mesmo uma rede conectada a outros elos, responsáveis por atividades correlatas. Tais redes de exportação são de importância crescente no sistema de manufatura global contemporâneo" (Appelbaum et Gereffi, 1994).

A idéia central neste modelo é que as cadeias produtivas têm estruturas de comando (governance) nas quais uma ou mais empresas coordenam atividades econômicas geograficamente dspersas (Figura 1). A racionalidade econômica na cadeia produtiva vem do fato de que a(s) empresa(s) que comanda(m) a cadeia busca(m) dominar as atividades que são estratégicas e que agregam mais valor (Fleury et Fleury, 2000).

Essa metodologia de análise é apropriada na atual conjuntura, na qual países em desenvolvimento abandonam as estratégias de substituição de importações e promovem grande reestruturação industrial e produtiva para sua inserção global, tentando muitas vezes emular o sucesso do modelo asiático de desenvolvimento econômico e social, baseado no incentivo das exportações. 
Numa economia cada vez mais dirigida pelo mercado - que exige qualidade, variedade, rapidez e preços baixos - o conhecimento, a capacidade de aprendizagem e de inovação, a eficiência coletiva e a integração de cadeias produtivas são aspectos importantes que este modelo permite analisar.

\subsection{Estrutura da tese}

Depois da introdução geral precedente, a tese segue a seguinte estrutura:

No capítulo 2, apresenta-se a evolução recente e as principais transformações ocorridas nas Indústrias Têxtil e do Vestuário, os avanços tecnológicos, assim como a reestruturação e as novas configurações. Apresentam-se também os fatores de competitividade que regulam o mercado global e que influenciam a estrutura das cadeias produtivas e das empresas nelas participantes.

Aprofundam-se, ainda, aspectos recentes da conjuntura de ambas as indústrias nos países selecionados. Destaca-se a influência da regulamentação internacional do comércio de produtos têxteis e de vestuário, fazendo ênfase final nos diferentes regimes de maquila utilizados pela Indústria Hondurenha de Maquila de Roupas - IHMR, além de se descrever a restruturação do setor no Brasil.

No capítulo 3, apresentam-se os modelos e conceitos básicos que fundamentam teoricamente o estudo e faz-se uma revisão na literatura sobre redes inter empresariais e cadeias produtivas. Os conceitos adotados são o de Global Commodity Chains - GCC (Gereffi, 1994, 2000) e Global Value Chains - GVC (Gereffi, 2001, Fleury et Fleury 2002) utilizados como referência para modelar as cadeias de produção de vestuário nas quais as empresas do Brasil e de Honduras estão inseridas.

Ainda no capítulo 3, os conceitos de Progressão Industrial (Humphrey et Schmitz, 2000; 
Kaplinsky et Morris, 2001) e a tipologia de Modernização Industrial são apresentados como ferramentas para a análise, já que esses conceitos permitem desenhar a trajetória de aperfeiçoamento, melhoria e avanço que as empresas percorreram no caso dos NICs Asiáticos, exemplos de trajetórias de empresas asiáticas, do México e de países da Bacia do Caribe são modelados.

Ambos os conceitos e as experiências modeladas se combinam para construir o referencial teórico do estudo, formular as perguntas e elaborar a hipótese que se procurou validar neste estudo, as quais se enunciam no final do capítulo.

No capítulo 4, descreve-se e justifica-se a metodologia aplicada na pesquisa de campo e a sua escolha. Apresenta-se o conceito de estudo de casos múltiplos com base nos quais se faz uma recolocação da pergunta da pesquisa.

A seleção da amostra é justificada e detalhada neste capítulo, no qual se apresentam os instrumentos de pesquisa e os procedimentos metodológicos executados para a coleta de informações pr imárias e secundárias.

No capítulo 5, analisa-se primeiramente a trajetória das maquiladoras hondurenhas; elaboram-se modelos de acordo com o marco teórico apresentado anteriormente, mostrando seu posicionamento nas cadeias e o avanço obtido ou não.

Na segunda parte do capítulo 5, analisa-se a trajetória recente das empresas brasileiras da indústria do vestuário, durante o processo de reestruturação da década de 1990 e as estratégias coletivas para a competitividade internacional.

No final desse capítulo, realiza-se a análise comparativa entre as trajetórias das empresas dos dois países, enquanto que as suas possibilidades de sucesso são sugeridas nas conclusões. 
As conclusões, apresentadas no capítulo seis, sintetizam a contribuição teórica deste estudo e as possibilidades de generalização para outras cadeias, setores e países, assim como as limitações do estudo e possíveis desdobramentos ou estudos complementares no futuro. 


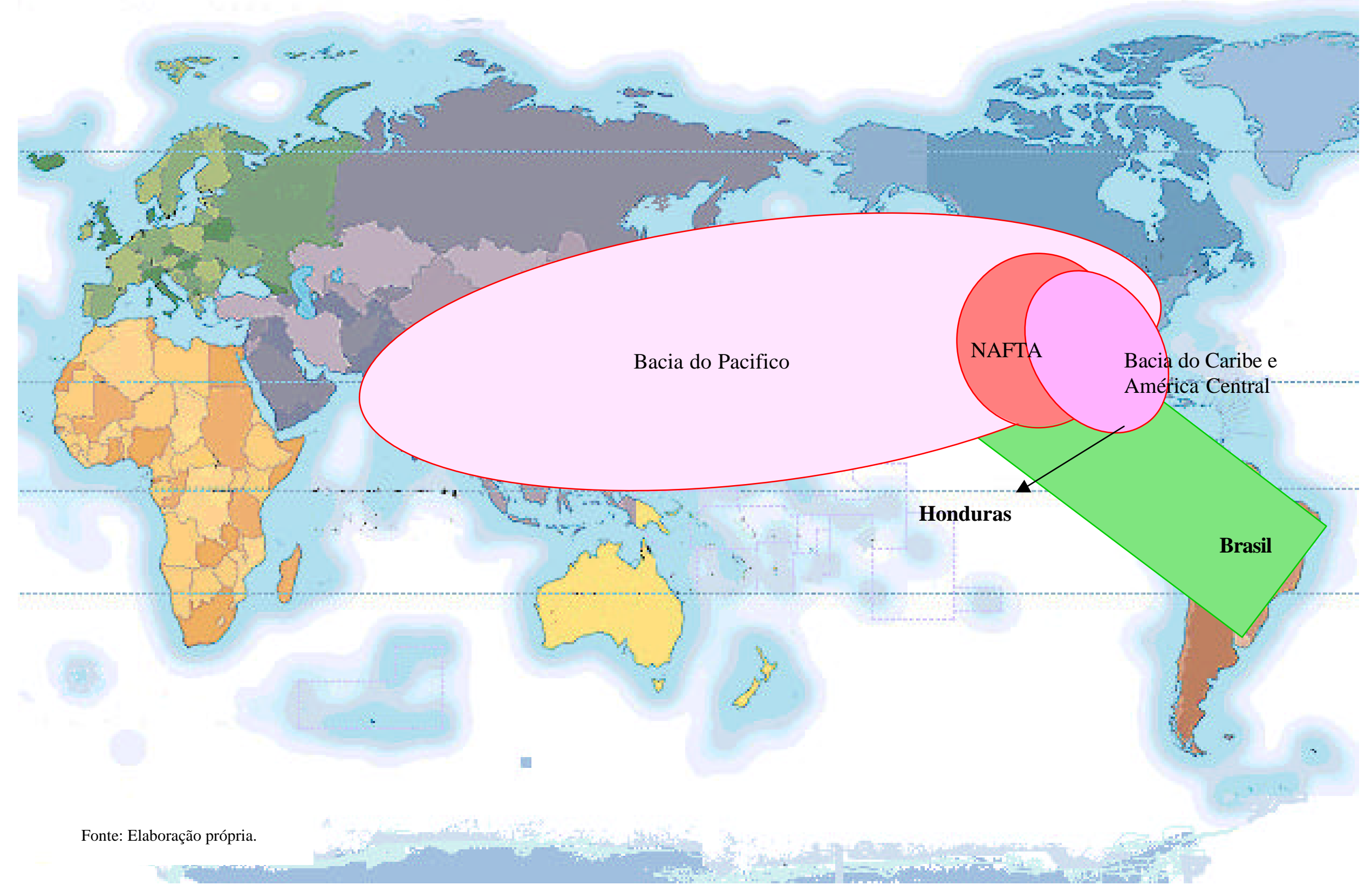




\section{CAPÍTULO 2}

\section{AS INDÚSTRIAS TÊXTIL E DO VESTUÁRIO \\ COMO CAMPO DE PESQUISA}

\subsection{Porque as indústrias têxtil e de vestuário são importantes para o estudo das cadeias produtivas globais?}

As primeiras indústrias a adquirirem dimensão global foram as do setores têxtil e do vestuário. São estas, igualmente, as mais geograficamente dispersas, tanto entre países desenvolvidos quanto naqueles em desenvolvimento. Para Dicken (1998), estas indústrias são muito complexas, pois contém elementos organizacionais novíssimos, bem como também antigos; sofrem constantes e rápidas mudanças, inclusive em sua geografia. De acordo com este autor, as transformações em ambas as indústrias, exemplificam muitas das questões da economia mundial atual, particularmente as tensas relações comerciais entre países desenvolvidos e em vias de desenvolvimento. São as indústrias na economia mundial com mais restrições especiais no comércio internacional através do Acordo dos Têxteis e da Confecção - ATC.

Para Kilduff et Priestland (2001), as mudanças estruturais da economia internacional têm como pilares básicos do desenvolvimento industrial os setores têxtil e do vestuário, 
ambos encontram-se bem próximos da vanguarda deste processo e continuarão a dinamizar o cenário internacional.

A fragmentação das etapas do seu processo produtivo permite, ao mesmo tempo, a dispersão geográfica e a mobilidade das atividades produtivas. Possibilita, ainda, a divisão do trabalho e dos lucros em forma desigual. A existência de etapas da produção intensivas em mão-de-obra - MDO e o baixo custo do posto de trabalho na etapa de costura (que continua basicamente constituído por um operador e uma máquina de costura) favorece a geração de emprego e, por isso, muitos governos nacionais vêem estas indústrias como estratégicas para o seu desenvolvimento industrial.

Para empresas e governos de países em desenvolvimento é importante entender as dinâmicas do comércio internacional de têxteis e vestuário, pois isto pode auxiliar a entender ou prever futuros cenários no âmbito de outras indústrias.

No meio acadêmico dos países em desenvolvimento, o estudo de casos das cadeias têxtil-vestuário pode contribuir na elaboração de um referencial teórico e empírico para abordar outros setores de importância para a economia e o desenvolvimento industrial.

Tanto em Honduras quanto no Brasil, este setor é de grande importância e, na última década, tem sofrido transformações consideráveis, seja em âmbito interno ou relacionado ao cenário externo, que afetam a sua participação nos mercados internacionais e vice-versa.

Apresenta-se, a seguir, uma breve panorâmica destas indústrias no mundo e de sua evolução recente em ambos os países. 


\subsubsection{A produção de roupas no mundo}

Vestir-se é uma das necessidades básicas do ser humano e, como tal, está presente em todos os momentos históricos do seu desenvolvimento. Foi assim desde os tempos do comércio da rota da seda, que levava às Índias Orientais e à China, dos famosos linhos do Egito e dos brocados europeus. A indústria têxtil desempenhou um papel importante quando ocorreu a mecanização dos teares, provocando a primeira revolução industrial.

A cadeia produtiva têxtil-vestuário é constituída tradicionalmente por grandes setores industriais (fig.2.1): a indústria química provedora de fibras feitas pelo homem (usualmente chamadas fibras manufaturadas ou fibras químicas) e insumos para tinturaria e acabamento; a indústria agropecuária fornecedora de fibras naturais, tanto vegetais como animais e a indústria têxtil, que usualmente inclui a fiação, transformando as matérias primas em tecidos para a indústria da confecção, que por sua vez os transforma em vestimenta para serem oferecidas ao consumidor final por diferentes canais de comercialização.

No comércio mundial de têxteis e vestuário os artigos variam desde os mais luxuosos, de marca reconhecida, passando por artigos padrão de produção em massa até aqueles que são vendidos como commodities, inclusive as pseudo-commodities. Fleury, Fleury, CruzMoreira et al(2001) definem assim as commodities:

"As commodities podem ser definidas ao longo de toda a cadeia produtiva têxtil, desde as fibras básicas, os filamentos parcialmente orientados e os mono ou multi filamentos, como produtos de baixa diferenciação, cuja tecnologia de fabricação é de domínio universal, produzidos em grande escala e com preços dependentes da oferta global (e portanto sujeitos a dumping devido à sobre-oferta do momento). 


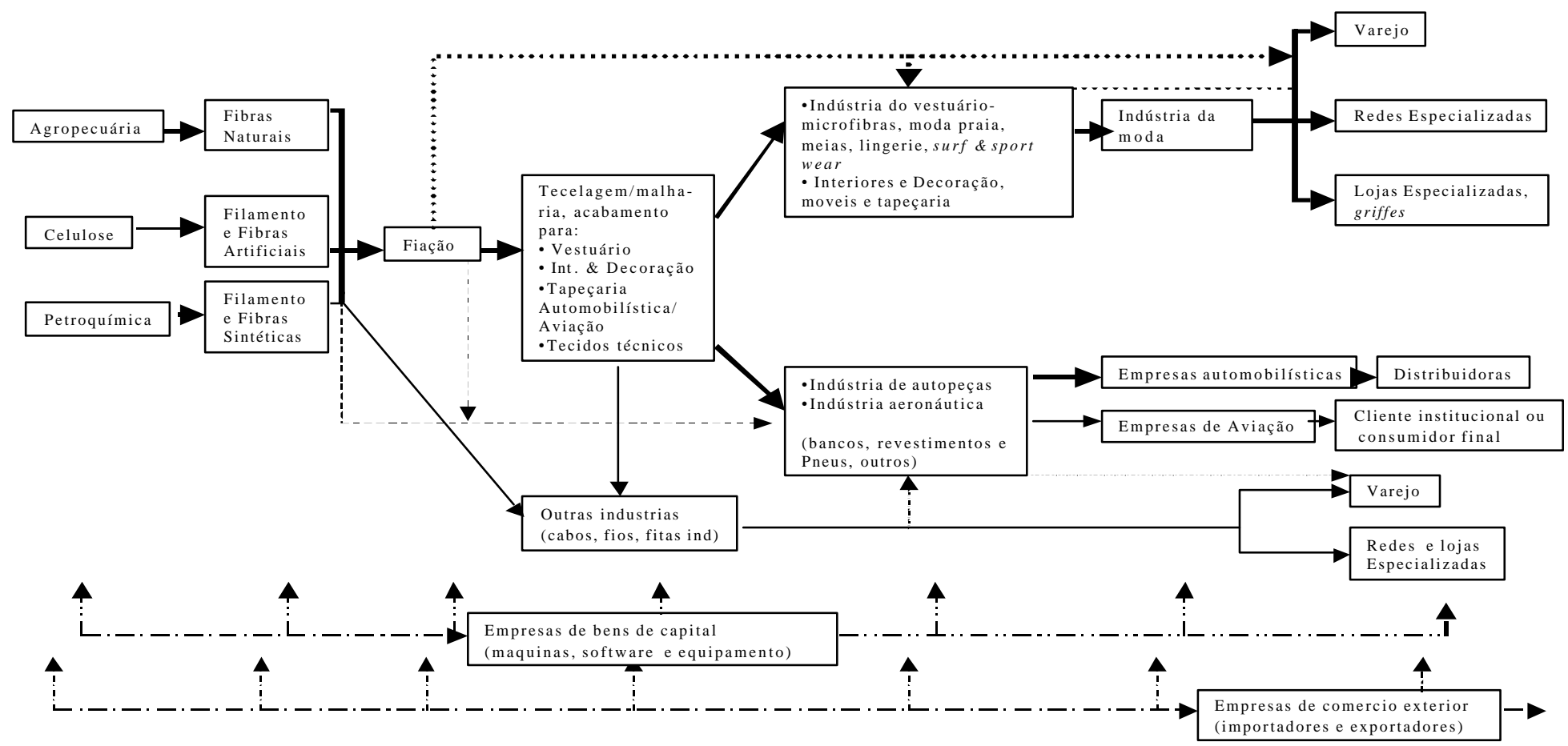


No âmbito dos tecidos podemos considerar como commodities os tecidos básicos, de produção em grande escala e com poucas características diferenciadoras. Quanto ao vestuário, camisetas, meias, lingerie e jeans são exemplos dos produtos que podem ser considerados commodities, exceto quando eles têm maior valor agregado, seja por características diferenciadoras do tecido ou design, resultando, por exemplo, em produtos com melhor desempenho para o uso destinado. No mesmo segmento diferenciam-se, também, os produtos de marca, as chamadas "griffes", cujo apelo é tanto pela qualidade quanto pelo aspecto intangível de status social associado a esses produtos.

As pseudocommodities da indústria química seriam caracterizadas pela diferenciação, ou seja, elas são produzidas "sob demanda" mas em bateladas ("batches") de acordo com o tamanho do pedido, enquanto as especialidades seriam produtos de alta diferenciação e baixa escala de produção em plantas dedicadas. Em geral estes são produtos que incorporam grandes desenvolvimentos de tecnologia e são defendidos por patentes, enquanto os primeiros não são." (Fleury, Fleury, Cruz-Moreira et al, 2000.p.11)

Somente no início da década de 1980 os avanços tecnológicos propiciados pelo uso da microeletrônica vão marcar profundas transforma ções no setor industrial e na economia, devido à produtividade alcançada na fabricação de tecidos, representando a primeira mudança significativa no processo de produção de vestuário desde e durante os 50 anos anteriores (Hoffman, 1985).

$\mathrm{Na}$ fase de montagem, apesar das máquinas de controle numérico e algumas inovações da robótica, os avanços mais significativos continuam limitados às etapas de prémontagem com o desenvolvimento de sistemas de design e de corte, auxiliados por CAD/CAM. Porém, na costura, até hoje a unidade básica de produção é constituída por uma máquina de costura e um operador (basicamente igual nas grandes empresas 
industriais e na produção artesanal caseira), e, por isso, esta é ainda uma etapa intensiva em mão-de-obra - MDO.

As rápidas transformações estruturais nos países desenvolvidos, a flexibilização da produção, a liberalização do comércio internacional e a descontinuidade das etapas produtivas permitiram uma rápida segmentação da produção no complexo têxtilvestuário.

No mapa do comércio de têxteis e vestuário destacam-se três grandes centros de consumo: Estados Unidos, União Européia e Japão, entre os países desenvolvidos. Já os fornecedores estão menos concentrados, mas podem agrupar-se em regiões de países que suprem as demandas dos grandes mercados, entre os quais estão: o México e países da América Central e do Caribe, que respondem por grande parte do mercado americano; a Europa Central e Oriental e alguns países africanos que fornecem para a União Européia; e os competitivos países do Norte, Sul e Sudeste da Ásia, competindo no globo inteiro. Entre os países asiáticos, merece destaque a temida China, que ameaça tomar o mercado de todos a partir de 2005.

Para Kilduff et Priestland (2001), as competências essenciais da indústria têxtil estão relacionadas com a escala da indústria: a produtividade, o design e a capacitação técnica. As debilidades chave estão relacionadas à produção inflexível e ao ambiente conservador, concentrados mais no volume e na produtividade e menos na criatividade e no serviço.

Por isso, as empresas dos países industrializados têm investido em crescimento tecnológico. Como exemplo, o desenvolvimento de fibras de alta tecnologia como o "kéblar" (uma das marcas da empresa americana Dupont), que pertence ao tipo de fibras de carbono das "aramidas" e são utilizadas em aplicações de alta resistência como coletes anti-balas e os cabos de conexão dos trajes espaciais. Outras fibras de alta tecnologia como o "nómex" e o "zylon" são resistentes às altas temperaturas e, 
portanto, ideais para roupas de bombeiros e de corredores de Fórmula 1 (Newman, 2003).

O Comando Militar de Investigações Biológicas e Químicas dos Estados Unidos, em Nantick, MA, desenvolve materiais para vestimentas e albergues do pessoal militar. Entre os seus projetos estão um hangar portátil sustentado por vigas que são tubos de tecido cheios de ar e também roupas de camuflagem que façam invisíveis os "guerreiros do futuro" (Newman, 2003). Estes e outros produtos serão, eventualmente, adaptados a usos mais comerciais como roupas e equipamentos médicos e desportivos e também para a indumentária comum, aumentando o seu conforto e conferindo competitividade a quem ofereça produtos com maior qualidade e inovação.

As empresas, ademais, investem em mudanças na estrutura organizacional e na cadeia produtiva, tais como enxugamento, descentralização e deslocamento da produção para a obtenção de custos baixos nos países em desenvolvimento; flexibilidade de produção e capacidade de resposta rápida, implementando inovações na cadeia de fornecimento por meio de tecnologias de informação - TI e transporte.

Este desenvolvimento tecnológico tem contribuído para consolidar os conceitos de operações globais e de Outsoursign ou ainda GlobalSourcing como práticas necessárias das empresas globais, que precisam buscar os melhores recursos e entrelaçá-los a uma rede rápida e com boa relação custo-benefício, independentemente de localização. Os fornecedores devem ser administrados de forma que sejam neutralizados os problemas causados pela distância, diferenças de horários, práticas comerciais, impostos e outros impedimentos para o eficiente fluxo de materiais e informações. As novas tecnologias permitem realizar as entregas exatamente como se estivessem na porta ao lado.

Assim, as empresas que dirigem a produção e lidam com o desafio de seduzir o consumidor final têm de utilizar eficientes canais de comercialização. Para isso existem as modernas tecnologias de informação e comunicação, gestão da logística e da 
distribuição, intensivamente o design, o marketing e a publicidade, e a da gestão da marca.

As marcas tanto dos produtores como dos varejistas ou das empresa líderes (mesmo que produtoras de insumos) são bens intangíveis, que junto às habilidades da gestão da cade ia de fornecedores podem agregar maior valor e lucros que outras estratégias como, por exemplo, a de preços baixos (Bovet et Martha, 2001).

Por último: as roupas também não são mais como na época da primeira revolução industrial, assim como a sociedade nã o está definida em poucos grupos de indivíduos como os nobres, o clero, ricos e pobres. As roupas da realeza eram feitas até com fios de ouro e pérolas, por artífices e costureiros reais. A plebe também elaborava de forma artesanal suas próprias roupas com tecidos simples.

Hoje não se pode classificar os consumidores e seus respectivos nichos de mercado somente pelo poder aquisitivo. As tendências de moda e o poder das marcas determinam o que a maioria deve vestir. Além disso, numa sociedade cada vez mais democrática, as diversas "tribos" têm cada uma estilos de vida diferentes e a indumentária particular faz parte de sua linguagem e formas de expressão. Algumas destas tribos são globais, outras continuam restritas a países ou a autênticos grupos étnicos que preservam suas vestimentas tradicionais.

\subsubsection{Empresas emblemáticas da "nova" indústria do vestuário}

Algumas empresas fizeram e fazem história nas indústrias têxtil e de vestuário: as norte-americanas Levi Strauss \& Co. e The Gap têm internacionalizado sua produção e comercialização. A primeira foi, inicialmente, uma empresa produtora que cresceu no mercado dos Estados Unidos e, depois, como multinacional, implantou subsidiárias em vários países, inclusive no Brasil. 
A The Gap iniciou-se como varejista vendendo produtos de outras marcas como a Levi's, criando depois a sua própria marca. Suas linhas e coleções de roupas próprias são também produzidas por outras empresas subcontratadas, principalmente no exterior.

A empresa italiana Benetton é um ícone na indústria do vestuário. Utilizando sistemas eletrônicos de intercâmbio de dados (Electronic Data Interchange - EDI), a empresa revolucionou a gestão de estoques, o planejamento da produção e o marketing na cadeia de produção de roupas. Esta empresa é um dos modelos de sucesso e liderança nas redes de cooperação de pequenas empresas nos "distritos industriais" italianos.

Empresas como a Nike já nasceram globais e nunca fabricaram uma peça. Suas competências são o design, a gestão da cadeia de suprimentos e o marketing, fundamentado no patrocínio dos mais famosos times esportivos do planeta, em quase todos os esportes.

A Toyota, empresa japonesa que desenvolveu o Just-In-Time - JIT, revolucionando a organização produtiva, e que antes de fabricar automóveis produzia teares, ajudou a novíssima empresa espanhola Zara a desenhar sua cadeia de suprimentos. A empresa tem conseguido superar as marcas de ciclo de produto da Benetton que foi a primeira a oferecer seis coleções por ano. A Zara é uma das cadeias de vestuário mais bem sucedidas e de maior crescimento atual na Europa, oferecendo a cada semana duas entregas de novos produtos aos seus fidelíssimos clientes. Esta marca recentemente abriu loja em São Paulo.

À montante temos, por exemplo, a Dupont que, em 1935 lançou o náilon e que já foi líder em produção e ainda hoje o é em inovação, grande parte da sua governance radica no valor de suas marcas como o da famosa Lycra.

As novas vedetes são os "infomediários" (Gereffi, 2001), como os portais de negócios como "Intentia", onde começam a realizar-se transações B2B, como leilões para o 
outsourging global, não somente de matérias primas como de produtos completos realizados sob a modalidade de full-package.

A seguir, será apresentada a evolução das indústrias têxteis e de vestuário dos países escolhidos, com o intuito de delinear as suas trajetórias de inserção nas atuais Cadeias Produtivas Têxteis-Vestuário - CPTV.

2.2

\title{
A indústria do vestuário em Honduras, estratégias de industrialização e de geração de emprego baseadas na exportação
}

\subsubsection{Maquilas e integração da produção entre as Américas do Norte e Central e o Caribe}

\begin{abstract}
“A palavra 'maquila' é de origem árabe e denomina a porção de grão, farinha ou azeite que cobrava o moedor pelo processo de moer o grão. Faz referência a uma atividade produtiva na qual o "produtor" não é o dono de uma ou de várias das matérias primas usadas no processo. A produção se realizava por conta e risco alheio, e cobra-se uma comissão fixa pelo trabalho. Na atualidade, por causa da globalização, a palavra maquila é usada para referir-se a atividades que não necessariamente coincidem com o uso original. Freqüentemente o termo é utilizado no sentido jurídico: maquila é tudo o que a legislação ou regime tarifário assim o considere." (CEPAL, 1998 p. 3-4)
\end{abstract}

Há muito em comum entre as trajetórias das empresas hondurenhas e as dos demais países da América Central e, em menor grau, às dos países do Caribe, destacando-se entre estes a República Dominicana. O México também tem um papel importante como um dos principais competidores que obteve maiores vantagens desde o início do Tratado Norte-americano de Livre Comércio - NAFTA. 
Talvez o papel mais relevante corresponda aos Estados Unidos, que detêm o principal mercado e utilizam leis de acesso preferencial para produtos de países da Bacia do Caribe, com acordos bi e multilaterais. Esses mecanismos funcionam como ajuda para o desenvolvimento dos países vizinhos e como estratégias de proteção para sua própria indústria, principalmente no caso dos têxteis e do vestuário, setor que nos ocupa.

Nos anos oitenta começou-se a notar o auge da Indústria Maquiladora de Exportação da América Central, quando a indústria estadunidense afrontou a maior concorrência dos produtos asiáticos, além de ocorrer uma mudança no gosto dos consumidores e um crescente dinamismo dos centros de distribuição do varejo. Diante dessa situação, o setor reagiu aplicando novas tecnologias no início do processo produtivo e transferindo, em maior medida, as atividades intensivas em MDO para o México, a América Central e o Caribe.

A relocalização veio acompanhada de sistemas de resposta rápida ${ }^{1}$, enlaçando produtores com provedores de insumos e com distribuidores, reduzindo o tempo para o processamento dos pedidos, de meses para alguns dias. A pesquisa realizada pela Comissão Econômica para América Latina e o Caribe - CEPAL destaca que, no início, as empresas americanas tiveram problemas com prazos de entrega e qualidade, mas logo foram resolvidos.

Estes são elementos necessários para entender o contexto em que evolui a indústria maquiladora hondurenha nas últimas décadas do século 20. Ilustra-se então, a seguir, o

\footnotetext{
${ }^{1}$ No caso centro -americano, além do fornecimento Just-In-Time - JIT e da eliminação dos estoques nas empresa americanas, há outra implicação adicional que se refere à "produção de pacote completo". O pacote completo na confecção repassa para o subcontratado todos os detalhes da produção, o que representa mais que uma mera soma de atividades. É necessário saber onde encontra-se disponível, de maneira imediata, o tecido requerido, suas restrições de qualidade, seu preço, os meios para transportá-lo rapidamente até a confecção. Requer alianças estratégicas bem constituídas, um forte domínio da informática, e principalmente, contatos internacionais. Um forte empresário hondurenho, proprietário de várias maquiladoras e de uma zona franca (Jacobo Kattán), comentou que a batalha dos próximos anos se daria no campo da resposta rápida (Gitli,1997).
} 
panorama centro-americano, para depois analisar a trajetória das empresas maquiladoras de roupas.

No final dos anos setenta, as atividades industriais na América Central restringiam-se ao seu mercado interno e ao centro-americano, dada a alta rentabilidade permitida pela proteção elevada e pelos amplos subsídios favoráveis à produção local (Gitli, 1997). Ainda no início dos anos oitenta, as exportações centro-americanas seguiam altamente concentradas em alguns setores agropecuários - café, banana, carne, açúcar - , apesar de sua estrutura produtiva encontrar-se bastante diversificada, representando o produto industrial 23,75\% do PIB total em 1980 (Gitli, 1997).

No período de 1985 a 1996 a situação começa a mudar. Enquanto a participação das exportações da América Latina para países da Organização para Cooperação e Desenvolvimento Econômico - OCDE tem se mantido estável, a participação dos países da América Central tem aumentado consideravelmente, de 0,20\% em 1990 para 0,35\% em 1998 (Dussel, 2001) $^{2}$. A tabela 2.1 ilustra as tendências exportadoras gerais dos países centro-americanos e de seus principiais competidores de 1985 a 1998.

${ }^{2}$ De acordo com a CEPAL (1998), os países da América Central, o México e a República Dominicana elevaram de forma significativa sua participação no comércio internacional, registrando taxas de crescimento similares a de países do sudeste asiático, ultrapassado-os em alguns casos. Devido ao fato de que, muitas vezes, as exportações das maquilas não se registram nos dados de exportações gerais das nações, os autores utilizaram dados de importação dos países receptores.

Entre 1990 e 1995, os países da região aumentaram sua participação nas exportações aos mercados dos países da OCDE. El Salvador apresentou um crescimento de $88,7 \%$, ficando em segundo lugar, somente atrás da China; Honduras aumentou suas exportações em 55\% - o mesmo valor do que a Tailândia; as exportações de Guatemala, México e República Dominicana cresceram 40\% - valor similar ao de Singapura, e Costa Rica teve o menor crescimento, 32,5\%, mas ainda assim considerável (CEPAL, 1998). 
Tabela 2.1- $\quad$ Participação e variação percentual das exportações no mercado dos países industrializados, 1985-1998 (Países selecionados)

\begin{tabular}{|l|r|r|r|r|r|}
\hline & & & & & \\
& $\mathbf{1 9 8 5}$ & $\mathbf{1 9 9 0}$ & $\mathbf{1 9 9 6}$ & \multicolumn{1}{|c|}{$\begin{array}{l}\text { Variação \% } \\
\mathbf{1 9 8 5}-1998\end{array}$} \\
\hline Países industrializados & 62,13 & 66,53 & 62,93 & 62,84 & $\mathbf{1 , 1}$ \\
\hline Estados Unidos & 10,47 & 10,29 & 10,61 & 10,92 & $\mathbf{4 , 3}$ \\
\hline América Latina & 5,73 & 4,57 & 5,32 & 5,70 & $\mathbf{- 0 , 5}$ \\
\hline Argentina & 0,31 & 0,27 & 0,23 & 0,22 & $\mathbf{- 2 9 , 0}$ \\
\hline Brasil & $\mathbf{1 , 3 4}$ & $\mathbf{1 , 0 2}$ & $\mathbf{0 , 8 3}$ & $\mathbf{0 , 8 3}$ & $\mathbf{- 3 8 , 1}$ \\
\hline México & 1,77 & 1,52 & 2,42 & 2,81 & $\mathbf{5 8 , 8}$ \\
\hline Mercado comum Centro-americano & 0,26 & 0,20 & 0,31 & 0,35 & $\mathbf{3 4 , 6}$ \\
\hline Costa Rica & 0,07 & 0,08 & 0,10 & 0,12 & $\mathbf{7 1 , 4}$ \\
\hline El Salvador & 0,05 & 0,02 & 0,05 & 0,05 & $\mathbf{0 , 0}$ \\
\hline Guatemala & 0,06 & 0,05 & 0,07 & 0,08 & $\mathbf{3 3 , 3}$ \\
\hline Honduras & $\mathbf{0 , 0 6}$ & $\mathbf{0 , 0 4}$ & $\mathbf{0 , 0 7}$ & $\mathbf{0 , 0 9}$ & $\mathbf{5 0 , 0}$ \\
\hline Nicarágua & 0,02 & 0,01 & 0,02 & 0,02 & $\mathbf{0 , 0}$ \\
\hline República Dominicana & 0,09 & 0,09 & 0,12 & 0,14 & $\mathbf{5 5 , 6}$ \\
\hline República da Coréia & 1,47 & 1,81 & 1,71 & 1,64 & $\mathbf{1 1 , 6}$ \\
\hline China & $\mathbf{1 , 0 2}$ & $\mathbf{1 , 8 5}$ & $\mathbf{4 , 0 1}$ & $\mathbf{4 , 4 6}$ & $\mathbf{3 3 7 , 3}$ \\
\hline Taiwan & 1,91 & 2,08 & 1,96 & 1,96 & $\mathbf{2 , 6}$ \\
\hline
\end{tabular}

Fonte: Variação \% calculada a partir de outros dados do CAN 2000 (CEPAL) In Dussel 2001.

A América Central apresentou uma taxa média anual de crescimento das exportações para os Estados Unidos de 17,3\%, entre 1990 e 1999, superior à taxa de crescimento das importações totais deste país, duplicando sua participação de 0,55 a 1,1\% (Dusell, 2001).

De acordo com o relatório da $\mathrm{CEPAL}^{3}$, os países da América Central e a China apresentam um padrão similar de mudança estrutural, indo na direção das indústrias de manufaturas maduras. O México e os países do Sudeste Asiático conseguem progredir em direção às manufaturas novas.

\footnotetext{
3 Na comparação feita por Fajnzylber (1991) 1978 a 1988, entres 51 países, somente o México tinha aumentado sua participação e, junto com a República Dominicana, estavam classificados na categoria 1 do grupo dos ganhadores (cada grupo de "ganadores" e "perdedores" foram subdivididos ainda em três categorias hierárquicas). A CEPAL (1998) aplicou novamente a metodologia aos mesmos países e no período de 1990 a 1995 os ganhadores da primeira categoria foram: China, El Salvador, Guatemala, Honduras, Malásia, México, República Dominicana, Singapura e Tailândia. Utilizando a mesma metodologia foi feita a mesma análise para o mercado de América Latina, os ganhadores (desta vez subdivididos somente em 4 categorias os grupos de ganhadores e perdedores) são: Indonésia, Grécia, Singapura, Tailândia, Filipinas, Honduras e Malásia, o que indica uma competitividade mundial, segundo o relatório (CEPAL, 1998- pp. 6-12).
} 
No caso da América $\mathrm{Central}^{4}$, as exportações da IME têm como carro-chefe as exportações de vestuário para os Estados $\operatorname{Unidos}^{5}$ (80\% em 1995), para onde se dirigiram, na década passada, 90\% da produção da IME. Estes países exportaram juntos, para os Estados Unidos, US\$ 2 bilhões em 1990, representando uma participação de $9 \%$. Em 1995 exportaram US\$ 7,4 bilhões, alcançando uma participação muito próxima aos $19 \%$ (CEPAL, 1998).

Ao comparar-se o crescimento das exportações de vestuário das maquilas da América Central (tomando a região como uma unidade) e do México para os Estados Unidos, estes eram similares em 1990. No período de 1991 a 1993, houve uma grande expansão nas exportações centro-americanas de vestuário, que ultrapassaram o México. Com o NAFTA (1994) e com a desvalorização cambial, o México ultrapassou novamente a América Central em 1996. No entanto, o ganho do México não é somente sobre a participação dos países da América Central, mas também sobre a participação dos países asiáticos (Gitli, 1997).

A IME na América Central começou a consolidar-se aproximadamente na metade da década de 1980 como conseqüência de fatores internos e externos. Entre eles destacamse: o estancamento e o esgotamento do modelo de industrialização pela substituição de importações ISI, no âmbito interno; e a redefinição da divisão internacional do trabalho, no âmbito externo, segundo o estudo da CEPAL (1998), ressaltando três acontecimentos para o crescimento da atividade maquiladora:

\footnotetext{
${ }^{4}$ De acordo com Dussel (2001, p. 18), que utilizou o programa CAN e a metodologia de Fajnsylber, os países da América Central parecem ter posicionado vantajosamente suas exportações à OCDE - com "estrelas nascentes" e atividades em "retirada", que representam 37,49\% e 27,38\% das exportações totais, respectivamente- particularmente El Salvador e Honduras.

${ }^{5}$ As importações industriais representam $63 \%$ das importações totais dos Estados Unidos procedentes da América Central, incluindo o valor final dos produtos da maquila (e não somente o valor adicionado aos insumos importados pelos Estados Unidos). Os produtos de vestuário representaram, entre 50\% e 80\% dos produtos industriais do total das importações em 1995. Muitos destes produtos são reexportados pelos EUA, porém os maquiladores desconhecem seu destino final (CEPAL, 1998).
} 
- A estratégia de industrialização baseada nas exportações não tradicionais ${ }^{6}$ para o mercado externo à região centro-americana e o restabelecimento das atividades e o ajuste dos padrões macroeconômicos regionais. Também por causa da crise do início dos anos 80, as políticas públicas voltaram-se para a modernização do marco legal e institucional, procurando diminuir o viés anti-exportador do modelo anterior.

- A cooperação internacional, principalmente a estadunidense, foi orientada a fortalecer as exportações de manufaturas como mecanismo de inserção dos países da América Central no comércio mundial. A América Central tomou certa prioridade nas políticas estadunidenses de desenvolvimento depois da Revolução Sandinista ${ }^{7}$ e da chegada ao poder dos Republicanos, que outorgaram mais fundos para projetos de desenvolvimento e facilidades de acesso preferencial para produtos manufaturados na América Central e no Caribe.

- A reestruturação da indústria manufatureira estadunidense, particularmente a indústria da confecção, cuja situação foi agravada pela concorrência dos asiáticos, encontrou nos baixos custos de MDO e proximidade geográfica uma oportunidade para concorrer com os asiáticos ${ }^{8}$.

\footnotetext{
${ }^{6}$ Entenda-se exportações “não tradicionais” dos países da região para os EUA, o que incluí alguns produtos agrícolas novos, assim como os da aqüicultura e marino cultura, e seus derivados já processados como produtos alimentícios.

${ }^{7}$ Segundo Gitli (1997), o forte crescimento da maquila em Honduras está claramente associado ao fim da guerra em Nicarágua.

${ }^{8}$ Sobre a importância da maquila na nova divisão do trabalho e sua relação entre relocalização e competitividade, a Comissão de Comércio Internacional dos Estados Unidos - USITC, justificou-a assim:

"Uma quantidade de empresas estadunidenses recorrem à montagem no exterior para reduzir os custos da manufatura a fim de manter a competitividade frente aos seus principais rivais, tanto estrangeiros como domésticos. Preservando a participação no mercado dos Estados Unidos e melhorando a competitividade por preço das exportações estadunidenses, ao beneficiar-se da montagem a baixo custo, as companhias são capazes de reter altos níveis de produção e emprego dentro do país, que de outra forma não seriam possíveis" (USITC 1996:1-1 apud Gitli, 1997.-p.8).
} 
Gitli (1997) acrescenta que, na segunda metade da década de 1980, há dois elementos que incidem fortemente no crescimento industrial:

- A reativação do mercado regional, associada ao advento da paz, primeiro na Nicarágua, logo depois em El Salvador e mais recentemente na Guatemala. O mercado centro-americano se dinamiza não somente por impulsos da demanda, mas porque durante esses anos foram reestruturadas todas as instituições e suas políticas econômicas, incluindo a tarifa externa comum em torno de uma abertura comercial maior dos países entre $\mathrm{si}^{9}$, e tendo o regionalismo aberto como novo eixo estratégico.

- Em segundo lugar, os anos noventa foram de forte crescimento da maquila, cuja participação se quadruplicou no caso de El Salvador e triplicou no caso da Guatemala e Honduras. Ela surge com força na Nicarágua e continua sua ascensão na Costa Rica, país que apresenta um estancamento a partir de 1996.

\subsubsection{Evolução das maquilas no México e na América Central}

A transformação do modelo de industrialização e a escolha da exportação por meio de maquilas não foram somente reações aos incentivos externos na América Central Nestes países, considerou-se importante acolher e desenvolver uma indústria maquiladora baseada no trabalho manual intensivo, como é o caso das confecções. Esta seria uma condição prévia e, em certa medida, preparatória para uma segunda fase de empresas maquiladoras caracterizadas pela incorporação de tecnologias novas, pela

\footnotetext{
${ }^{9}$ Exceto Honduras, os países da América Central apresentam uma tendência clara para o aumento da participação nas exportações intra-regionais, do qual poderia esperar-se um impulso para a manufatura (nos últimos anos Nicarágua impôs tarifas de 35\% para as importações de Honduras, país que finalmente ganho a disputa na OMC).
} 
adição de maior valor agregado e pela vinculação aos setores produtivos nacionais (CEPAL, 1998) ${ }^{10}$.

A tabela 2.2 apresenta uma síntese da classificação feita por Carrillo et Hualde (1997) para as maquiladoras mexicanas. Esta classificação foi considerada apropriada pela CEPAL (1998) para o caso das empresas maquiladoras da América Central, apesar de, neste caso, não encontrarem ou julgarem nenhuma empresa com as características da terceira geração ${ }^{11}$.

A CEPAL então propõe uma análise da evolução das maquilas, utilizando para isto também a classificação das maquilas de acordo com o esquema de tarifas de acesso ao mercado estadunidense de produtos têxteis e de vestuário, já que este é o principal e quase único mercado de destino das exportações da América Central no caso das indústrias têxtil e de vestuário.

O programa de preferências introduzido pelo governo dos Estados Unidos em 1963, conhecido como ingresso aduaneiro "806.30" e "807.00" passou a pertencer ao capítulo 9802.00.60 (que se refere a artigos de metal) e 9802.00.80 (que abarca quase todas as demais atividades), com o estabelecimento do sistema harmonizado para a designação e codificação de produtos.

\footnotetext{
${ }^{10}$ Algumas das empresas centro-americanas tomaram a decisão de "maquilar" para empresas americanas, para suprir a carência de sistemas de inovação e desenvolvimento, e poder, assim, transferir as novas técnicas de produção para suas linhas de produção dirigidas ao mercado local (CEPAL, 1998). Ademais, a produção de artigos de marcas internacionais valoriza suas marcas próprias, agrega prestígio para atrair novos clientes e os custos fixos de produção diminuem devido ao incremento dos volumes de produção.
}

Para isto, e como conseqüência, a organização do trabalho evoluiu na direção das práticas modernas de gestão, da contabilidade ao controle de qualidade, à diminuição de níveis hierárquicos, etc.

${ }^{11} \mathrm{O}$ estudo da CEPAL considera que numa comparação com as categorias das maquilas mexicanas, a maioria das maquiladoras centro-americanas estariam na categoria da segunda geração, à exceção de algumas da Costa Rica, talvez por terem sido as primeiras na década de 1970, época em que o investimento internacional era nesse tipo de empresas.

A pesquisa da CEPAL foi realizada em 60 empresas dos países analisados México, Costa Rica, El Salvador, Guatemala e Honduras. 
Na prática, os clientes americanos utilizam usualmente os termos 806, 807, 809, Corte, Costura e Acabamento - CCA e o Pacote Completo. Assim, as maquiladoras centroamericanas podem ser classificadas nos tipos apresentados na tabela 2.2.

É freqüente que as empresas do grupo $\mathrm{C}$ e as de pacotes completos operem duas linhas de produção: uma para o mercado nacional e outra para o mercado de exportação. No caso de Honduras, em nossa pesquisa, todas as grandes empresas priorizavam a exportação alegando que o mercado interno é inexpressivo. A empresa de capital taiwanês oferece seus serviços também para clientes nacionais, embora o alvo principal sejam as outras maquilas de exportação.

Na pesquisa de campo da CEPAL foram encontradas empresas de pacote completo em El Salvador, Guatemala e Honduras, embora predomine em ambos os países as empresas do tipo A e B. Em El Salvador e Guatemala isto se explica pelo relativo desenvolvimento de tecidos industriais previamente ao auge das maquilas Em Honduras, a causa provável que estimula as empresas a transferir os processos produtivos complexos e intensivos em MDO foi o baixo custo desta.

As empresas estrangeiras indicaram como principais causas de subcontratação da produção na América Central a redução de custos (proporcionado pela disponibilidade abundante de MDO com remuneração baixa) e a proximidade do mercado estadunidense. 
Tabela 2.2 - Tipos de maquiladoras por regime de preferências tarifárias nos EUA

e por atividades $r$ ealizadas

\begin{tabular}{|c|c|c|}
\hline $\begin{array}{l}\text { Tipos de } \\
\text { empresas }\end{array}$ & Características & $\begin{array}{l}\text { Tipologia de } \\
\text { Modernização } \\
\text { Industrial }\end{array}$ \\
\hline $\begin{array}{l}\text { Maquiladoras } \\
\text { tipo A } \\
(\mathbf{8 0 7 - A , 8 0 7 )}\end{array}$ & $\begin{array}{l}\text { Confecção-acabamento-embalagem: Esta categoria tipifica as } \\
\text { maquiladoras que montam os tecidos cortados nos Estados Unidos, } \\
\text { utilizando todos os acessórios (botões, etiquetas, fios, material para } \\
\text { embalagem, etc) provenientes deste país. A terminologia 807-A indica } \\
\text { que os tecidos são americanos e a } 807 \text { que os tecidos foram importados } \\
\text { pelos Estados Unidos. }\end{array}$ & \multirow{3}{*}{$\begin{array}{c}\text { OEA } \\
\text { (Original } \\
\text { Equipment } \\
\text { Assembly) }\end{array}$} \\
\hline $\begin{array}{l}\text { Maquiladoras } \\
\text { tipo B } \\
(806,809)\end{array}$ & $\begin{array}{l}\text { Corte-confeccão-acabamento-embalagem: Estas empresas trabalham } \\
\text { principalmente sob as categorias } 806 \text { e } 809 \text {, devem contar com } \\
\text { tecnologia para corte e secagem o que inclui sistemas para padronagem e } \\
\text { riscado, facilidades físicas para estoque, tingimento e corte dos tecidos, } \\
\text { pessoal capacitado nessas funções e em sistemas administrativos e de } \\
\text { controle da produção que permita a eficiência e o controle de } \\
\text { desperdícios para o controle alfandegário, também é necessária } \\
\text { tecnologia e facilidades físicas para a classificação e numeração das } \\
\text { partes. Tudo indica que nestas maquilas o produto tem maior valor } \\
\text { agregado do que nas do tipo A. Os produtos que ingressam sob a } \\
\text { categoria } 809 \text { devem ser produzidas com tecidos exclusivamente } \\
\text { americanos e os da categoria } 806 \text { podem ter os tecidos produzidos no } \\
\text { país da maquila ou em qualquer outro. (Assim a categoria } 806 \text { estaria } \\
\text { próxima da classificação OEM) }\end{array}$ & \\
\hline $\begin{array}{l}\text { Maquiladoras } \\
\text { tipoC }\end{array}$ & $\begin{array}{l}\text { Corte-manufatura-acessórios: As empresas maquiladoras devem fornecer } \\
\text { os aces sórios e a embalagem. Além de contar com as competências das } \\
\text { empresas na categoria } 806 \text {, devem ser capazes de manejar } \\
\text { financeiramente o capital de trabalho para o suprimento dos insumos. O } \\
\text { cliente somente fornece os tecidos, padronagem e o desenho básico das } \\
\text { roupas. }\end{array}$ & \\
\hline $\begin{array}{l}\text { As empresas } \\
\text { provedoras de } \\
\text { pacote } \\
\text { completo }\end{array}$ & $\begin{array}{l}\text { Esta categoria independe do regime de acesso ao mercado norte- } \\
\text { americano. As empresas que conseguem isto fornecem os tecidos e os } \\
\text { acessórios, realizam o corte e a manufatura que precisam as roupas, as } \\
\text { matérias primas, insumos e embalagem. O comprador proporciona } \\
\text { padronagem e desenhos básicos das roupas, na maioria dos casos decide o } \\
\text { tipo de tecido que deve ser utilizado. } \\
\text { Estas empresas contam com o capital necessário e são bem estruturadas, geralmente são } \\
\text { empresas tradicionais (OEM) com produção própria convertidas em recintos fiscais } \\
\text { (Zonas sob os regimes de maquila). }\end{array}$ & $\begin{array}{c}\text { OEM } \\
\text { (Original } \\
\text { Equipment } \\
\text { Manufacturing) }\end{array}$ \\
\hline
\end{tabular}

Fonte: Elaboração própria: incluídas informações de CEPAL (1998). 
De acordo com essa pesquisa, a prioridade competitiva das empresas era a qualidade (64\%). A relação preço/qualidade vinha em segundo lugar (27\%) e depois o preço (9\%) e o design e marcas (0\%). O alto grau de competição (México, Caribe, Leste Asiático e China) implica que a competição não se deu somente por preço e que os produtos têm de ser "classe mundial” (CEPAL, 1998).

Quanto às relações entre as empresas contratantes e as maquilas, a pesquisa da CEPAL observou que, no geral, havia pouco envolvimento das maquilas no que se refere à escolha de materiais e fornecedores, e bastante autonomia quanto ao modelo organizacional, à capacitação, ao recrutamento e, em menor medida, às estratégias de investimento e financiamento.

A autonomia para a escolha de maquinaria era diferente em cada caso, já que resulta da variedade de relações produtivas entre as empresas matrizes e filiais ou entre as contratantes e as subcontratadas. Ela também reflete as diferentes capacidades tecnológicas e produtivas das empresas. Na nossa pesquisa, encontrou-se praticamente total autonomia das empresas maquiladoras, exceto no caso de uma empresa em que as máquinas eram propriedade da empresa cliente.

Em relação aos recursos humanos, os aspectos mais destacados nessa pesquisa foram:

- A rotatividade na IME da América Central na época era de $25 \%$ anual $(2,1 \%$ mensal), menor do que no México, à época.

- Os trabalhadores recebem um salário base fixo, de acordo com o mínimo legal ou ligeiramente acima deste valor, alcançando um acréscimo de 50 a 100\% de acordo com as metas e a qualidade. 
Para o controle do processo, algumas empresas utilizavam sistemas eletrônicos de códigos de barras nas partes das peças de roupa e adaptavam leitores às máquinas onde os operadores registravam as tarefas realizadas.

As empresas de capital nacional pareciam ter mais chance de transmitir tecnologia por meio de processos de aprendizagem, por usar eventualmente duas linhas de produção, uma delas vinculadas ao mercado local. Ambas as linhas de produção contribuíam para a capacitação do pessoal, aumentando o acervo de capital humano disponível.

Para atrair o investimento internacional, os governos dos países da América Central abriram suas economias, desvalorizaram moedas, investiram em infra-estrutura e, ainda, criaram incentivos legais. Os dados a que se teve acesso com freqüência divergem, de acordo com a fonte: muitas vezes variam o número de empresas e o montante do investimento de cada uma, que geralmente não é divulgado. Os dados sobre o número de empregos e o valor agregado de suas exportações depende não só da origem do capital e da atividade realizada, como também dos regimes sob os quais as exportações se realizam, variando, igualmente, de acordo com a fonte. Por isso utilizam-se, em vários casos, os dados de outros estudos.

Na tabe la 2.3, nos dados compilados do relatório de Gitli (1997) para a OIT, percebemse os altos percentuais de empresas nacionais na Guatemala e em El Salvador, mas estes números são mais baixos na Nicarágua e na Costa Rica. Os investidores estrangeiros na região provêm dos Estados Unidos e da Coréia ${ }^{12}$, seguidas de outras empresas de origem asiática, exceto na Costa Rica, onde as empresas de "outros países" eram européias (Gitli, 1997).

\footnotetext{
${ }^{12}$ Em 1992, as inversões Coreanas na América Central eram de US\$ 23 milhões na Guatemala, US\$ 15 milhões na República Dominicana e US\$ 14 milhões em Honduras, donde devem ter diminuído os investimentos por conta de problemas culturais e laborais.
} 
De acordo com o mesmo autor, o investimento de operações asiáticas na região aumentou, mas tem sido maior no México do que na América Central desde a implementação do NAFTA.

Tabela 2.3 - Investimento internacional na maquila centro-americana por número e \% de empresas /país de origem (1996)

\begin{tabular}{|c|c|c|c|c|c|c|c|c|c|c|c|c|}
\hline \multirow{3}{*}{$\begin{array}{l}\text { Origem } \\
\text { das } \\
\text { empresas }\end{array}$} & \multicolumn{12}{|c|}{ País receptor do investimento } \\
\hline & \multicolumn{2}{|c|}{ Guatemala } & \multicolumn{2}{|c|}{ El Salvador } & \multicolumn{2}{|c|}{ Honduras } & \multicolumn{2}{|c|}{ Nicarágua } & \multicolumn{2}{|c|}{ Costa Rica } & \multicolumn{2}{|c|}{ Total AC } \\
\hline & $\begin{array}{l}\text { No. } \\
\text { Emp. }\end{array}$ & $\%$ & $\begin{array}{l}\text { No. } \\
\text { Emp. }\end{array}$ & $\%$ & $\begin{array}{l}\text { No. } \\
\text { Emp. }\end{array}$ & $\%$ & $\begin{array}{l}\text { No. } \\
\text { Emp. }\end{array}$ & $\%$ & $\begin{array}{l}\text { No. } \\
\text { Emp. }\end{array}$ & $\%$ & $\begin{array}{c}\text { No. } \\
\text { Emp. }\end{array}$ & $\%$ \\
\hline Nacional & 95 & 43,2 & 123 & 64,7 & 56 & 32,2 & 3 & 15,8 & 39 & 20,6 & 316 & 40 \\
\hline EUA & 20 & 9,1 & 20 & 10,5 & 62 & 35,6 & 6 & 31,6 & 113 & 59,8 & 221 & 28 \\
\hline Coreanas & 96 & 43,6 & 16 & 8,4 & 37 & 21,3 & 3 & 15,8 & 4 & 2,1 & 156 & 20 \\
\hline Outras Ásia & 4 & 1,8 & 12 & 6,3 & 17 & 9,8 & 6 & 31,6 & 3 & 1,6 & 42 & 5 \\
\hline Outros & 5 & 2,3 & 19 & 10 & 2 & 1,1 & 1 & 55,3 & 30 & 15.9 & 57 & 7 \\
\hline Total & $22^{\circ}$ & 100 & 190 & 110 & 174 & 100 & 19 & 100 & 189 & 100 & 792 & 100 \\
\hline
\end{tabular}

Fonte: Elaboração própria , Compilado de Gitli (1997) com dados provenientes de: Guatemala: GEXPRONT, El Salvador: Min. De Economia, Honduras: AHMA, Nicarágua: Corporación de Zonas Francas, Costa Rica: PROCOMER.

Os fornecedores da região para o mercado americano são diversificados e, em certa medida, especializados. O México se apresenta como um grande concorrente, principalmente depois do NAFTA. De 1993 a 1996 as exportações para os Estados Unidos cresceram de 4,8\% para 9,8\%, enquanto o conjunto das exportações da América Central passou de $6,3 \%$ a $9,4 \%$ (Gitli, 1997).

Na produção de calças (jeans, principalmente), o México apresenta a maior fatia de mercado [a cidade mexicana de Torreón está sendo chamada "a capital mundial dos jeans" (Bair, 2002- p.222)], embora Honduras e El Salvador apresentaram crescimento nestes itens no período analisado de 1992-1995. Já na produção de camisas, Honduras e República Dominicana seriam os grandes fornecedores regionais, de acordo com a análise de Gitli (1997). 
Quanto à roupa íntima masculina, constituída por cuecas de algodão (de malha e de outros tecidos) e camisetas, os dois produtos eram principalmente fornecidos ao mercado americano por países da região. O México apresentou maiores ganhos de participação nas camisetas, enquanto que Costa Rica, Honduras e El Salvador apresentaram maior especialização nas cuecas.

Outro segmento importante para a América Central é a roupa íntima feminina: calcinhas, meias e sutiãs. No geral, o México apresentou um maior ganho do que o conjunto dos países centro-americanos. Porém, Honduras apresentou um ganho muito maior do que o México na confecção de sutiãs.A tabela 2.4 apresenta os ganhos e as perdas de participação dos principais produtos importados pelos Estados Unidos no período de 1992 a 1995.

O auge centro-americano das exportações está associado à Iniciativa para os países da Bacia do Caribe - IBC, de 1984. Somam-se a esta iniciativa as desvalorizações cambiais das moedas locais em relação ao dólar, a adaptação e a modernização das leis de incentivos, os tímidos processos de abertura comercial nos anos de 1980, aprofundados na década seguinte, e a ação promocional da Agência dos Estados Unidos para o Desenvolvimento Internacional - USAID, que fomentou, além da maquila, as exportações não tradicionais. O congresso estadunidense aprovou uma resolução (599), em 1993, que proíbe as agências de promover o traslado dos empregos para outros países, nesse período há declínio de crescimento nas exportações consideradas não tradicionais.

O espectro de transformações permitidas sob o programa de maquilas dos Estados Unidos é muito amplo. É mais liberal nas autopeças, motores e qualquer outro setor que não têxteis e de vestuário, nestes muito mais restrito, em que qualquer pré-lavado da roupa faria perder o benefício preferencial. 
As tarifas de importação para os produtos da CPTV estão entre as mais altas nos Estados Unidos e não estão incluídas no SGP - Sistema Geral de Preferências nem na IBC.

Tabela 2.4 - $\quad$ América Central e México, perdas e ganhos de acordo com a participação constante de mercado nos 20 primeiros itens de confecção importados pelos Estados Unidos, 1992-1995 (em milhões de US\$ dólares)

\begin{tabular}{|c|c|c|c|c|c|c|c|c|}
\hline \multirow{3}{*}{$\begin{array}{l}\text { Itens/ } \\
\text { Produtos } \\
\text { 6203/ Ternos, calças } \\
\text { jaquetas, etc. Masc. }\end{array}$} & \multicolumn{8}{|c|}{ Países } \\
\hline & $\begin{array}{c}\text { Costa } \\
\text { Rica }\end{array}$ & $\begin{array}{c}\text { El } \\
\text { Salvador }\end{array}$ & $\begin{array}{c}\text { Guate- } \\
\text { mala }\end{array}$ & Honduras & $\begin{array}{l}\text { Nica- } \\
\text { rágua }\end{array}$ & Panamá & $\begin{array}{l}\text { América } \\
\text { Central }\end{array}$ & México \\
\hline & $-26,5$ & 10,2 & 51,3 & 13,0 & 26,0 & $-6,9$ & 67,2 & 287,6 \\
\hline $\begin{array}{l}\text { 6204/Conjuntos, calças, } \\
\text { vestidos, Fem. }\end{array}$ & -352 & 65,2 & $-2,2$ & 39,4 & 15,5 & $-6,8$ & 75,9 & 221,3 \\
\hline $\begin{array}{l}\text { 6110/'Sweters", jalecos, } \\
\text { etc. malha. }\end{array}$ & $-5,8$ & 39,6 & $-16,3$ & 72,0 & 6,6 & $-9,9$ & 86,2 & 256,2 \\
\hline $\begin{array}{l}\text { 6108/'Baby dolls", } \\
\text { pijam. Etc.Fem. malha. }\end{array}$ & $-17,6$ & 32,5 & $-2,0$ & 7,2 & 2,7 & 0,6 & 63,4 & 11,9 \\
\hline $\begin{array}{l}\text { 6109/Camisetas de } \\
\text { malha. }\end{array}$ & 12,1 & 39,7 & $-4,5$ & 41,5 & 0,1 & $-6,6$ & 82,3 & 241,3 \\
\hline $\begin{array}{l}\text { 6212/Sutiãs, corsetes, } \\
\text { cintaligas, etc. }\end{array}$ & $-44,7$ & 12,6 & $-1,2$ & 44,2 & 0,0 & 4,8 & 15,7 & 20,2 \\
\hline $\begin{array}{l}\text { 6105/Camisetas de } \\
\text { malha masc. }\end{array}$ & $-4,7$ & 10,9 & 13,0 & 13,9 & 6,1 & $-3,2$ & 36,1 & 22,4 \\
\hline $\begin{array}{l}\text { 6104/Conjunt. Calças, } \\
\text { vestidos Fem. malha. }\end{array}$ & $-2,5$ & 16,8 & 3,7 & 14,2 & 0,2 & $-6,5$ & 26,0 & 71,1 \\
\hline $\begin{array}{l}\text { 6111/Roupas e acc. de } \\
\text { malha p/bebes. }\end{array}$ & 12,9 & 10,5 & 9,1 & 1,2 & 0.0 & 0,0 & 33,8 & 2,2 \\
\hline $\begin{array}{l}\text { 6207/Roupa intima } \\
\text { Masc. }\end{array}$ & 16,6 & 10,2 & 4,1 & $\mathbf{0 , 0}$ & 0,9 & 0,0 & 31,7 & 3,7 \\
\hline $\begin{array}{l}\text { 6107/Roupa intima } \\
\text { Masc. de malha. }\end{array}$ & $-0,8$ & 2,4 & 0,1 & 19,5 & - & 0,0 & 21,2 & $-3,4$ \\
\hline $\begin{array}{l}\text { 6103/ Ternos, calças } \\
\text { jaquetas, Masc. Malha. }\end{array}$ & $-6,5$ & 2,4 & $-1,7$ & 13,5 & $\mathrm{O}, 2$ & -0.4 & 7,5 & 21,9 \\
\hline $\begin{array}{l}\text { 6208 Baby dolls", } \\
\text { pijamas, etc. Fem. }\end{array}$ & $-2,7$ & 16,4 & 2,36 & 6,7 & - & 0,0 & 22,6 & 4,6 \\
\hline $\begin{array}{l}\text { 6206/Camisas, blusas, } \\
\text { Fem. }\end{array}$ & $-4,5$ & 1,5 & 4,1 & $-1,0$ & 0,1 & 0,2 & 0,4 & 25,1 \\
\hline $\begin{array}{l}\text { 6211/Roupas desport, } \\
\text { c/p/esqui, de banho. }\end{array}$ & $-0,6$ & 0,7 & 8,1 & $-4,4$ & 0,1 & 0,0 & 3,9 & 10,8 \\
\hline $\begin{array}{l}\text { 6106/Camisas, blusas, } \\
\text { Fem. Malha }\end{array}$ & 0,4 & $-3,7$ & $-0,3$ & 4,0 & 2,4 & $-1,4$ & 1,4 & 32,4 \\
\hline $\begin{array}{l}\text { 6201/Abrigos, jaq. } \\
\text { Masc. Exceto 6203. }\end{array}$ & $-2,7$ & $-0,7$ & 6,4 & 3,8 & - & 0,0 & 6,8 & 9,6 \\
\hline $\begin{array}{l}\text { 6115/Meias e panty } \\
\text { meias Fem. de malha. }\end{array}$ & 11,3 & 14,4 & 0,0 & $-0,2$ & - & 0,1 & 25,5 & 16,4 \\
\hline $\begin{array}{l}\text { 6202/Abrigos, jaq. Fem. } \\
\text { Exceto } 6204 .\end{array}$ & $-5,6$ & 0,7 & 6,0 & 2,2 & 0,0 & 0,0 & 3,3 & $-3,9$ \\
\hline
\end{tabular}

Fonte: Adaptado de Gitli, 1997 com base em dados do U.S. Deparment of Commerce (MAGIC) 1996. 


\subsubsection{A trajetória das maquiladoras hondurenhas}

Honduras partilha com os outros países da América Central processos de industrialização similares. As políticas de substituição de importações - ISI, não foram bem sucedidas, assim como não foi a formação de um mercado consumidor local. A pouca demanda de mercado, à primeira vista, está relacionada à escassa população e ao seu baixo poder aquisitivo.

Ainda nos anos cinqüenta, a indústria hondurenha era incipiente e as formas de produção eram fundamentalmente artesanais. As fábricas -strictu sensu- limitavam-se a algumas processadoras de alimentos, bebidas e tabaco, cujas matérias primas vinham do setor agropecuário e se destinavam ao mercado interno (Mazier et Castillo, 2002).

A CEPAL e os cinco países da América Central acharam que o caminho para o desenvolvimento tinha de passar pela integração de seus mercados, por causa de sua estreiteza e falta de capital (Zelaya et al 1998).

Na década de 1960, Honduras incorpora-se ao processo de integração centro-americana. Foi então que começou a estratégia de industrialização por ISI. Porém, as tentativas no passado de um Mercado Comum, o MERCOMUN Centro-Americano, mostraram as dificuldades e o desequilíbrio da indústria local para a competição com os outros países da área.

O surgimento, desenvolvimento e auge da maquila em Honduras, depois do fracasso do MERCOMUN, e além das outras mudanças e influências do contexto internacional, têm de ser explicados à luz dos processos internos econômicos e sociais, os quais têm a ver com o esgotamento do modelo de ISI e também do modelo agro-exportador.

Os processos de ajuste estrutural e os caminhos escolhidos para a modernização econômica do país pautaram-se no aproveitamento das políticas econômicas dos Estados 
Unidos para a região e pelo conselho dos organismos internacionais de desenvolvimento econômico.

A criação do marco legal e jurídico para o funcionamento da maquila de exportação remonta ao ano de 1974, quando começam as políticas e estratégias de draw back ${ }^{13}$ nos Estados Unidos (embora não seja este procedimento exclusividade deste país). Em 1976 foi criada a primeira "Zona Libre de Puerto Cortés" ${ }^{14}$, uma estatal que funciona até hoje como centro de logística e consolidação de cargas, administrada pela Empresa Nacional Portuária - ENP.

Foram feitos estudos de mercado para produtos que fossem competitivos com as oportunidades da maquila estadunidense, com o apoio da Agência dos Estados Unidos para o Desenvolvimento Internacional - USAID ${ }^{15}$. Nessa época a iniciativa privadacria a Fundação para o Incentivo e Desenvolvimento das Exportações - FIDE ${ }^{16}$ e contratam consultorias internacionais para a realização de estudos e diagnósticos ${ }^{17}$. Os estudos ressaltaram as oportunidades para a montagem de produtos de vestuário, eletroeletrônicos e autopeças, entre outros. Dada a existência prévia da indústria têxtil e do vestuário e suas baixas barreiras de entrada, a atividade de montagem é a que predomina até hoje, apesar dos esforços para a diversificação, devido às preferências tarifárias dos Estados Unidos.

\footnotetext{
${ }^{13} \mathrm{O}$ draw back é um conceito padrão, aplicado mundialmente, que significa devolução dos direitos tarifários pagos pela importação de insumos que se incorporam fisicamente em produtos exportados. Aceito pela OMC como prática comum que não deve ser interpretada como subsídio, baseia-se no conceito de que as taxas indiretas devem ser cobradas ao consumidor final uma só vez.

${ }^{14}$ A primeira empresa a operar na "Zona Libre de Puerto Cortés" foi Warmaco Inc., produtora dos jeans Wrangler (Zelaya et al, 1998).

${ }^{15}$ Sigla em inglês.

${ }^{16}$ Atrair os investidores não foi automático somente com a aprovação das leis de ZOLI. De acordo com Norman Garcia - presidente de FIDE (e atual Ministro de Indústria de Honduras), mudar a reputação de país pobre no coração da América Central não foi uma tarefa fácil (Zelaya, et al, 1998).

17 Entre outros: (a)“A private sector export processing zone system for Honduras”, report for FIDE Tegucigalpa, Honduras" August 12,1986 - International Park, Inc. Flagstaff, Arizona, USA; e (b) “Honduras Free Zone Development: a Strategy for FIDE”. The Services Group, 1988.
} 
Para estimular o investimento internacional e as exportações, elaboraram-se leis especiais complementares às de importação preferencial dos Estados Unidos. Hoje coexistem três regulamentações legais para a maquila hondurenha ${ }^{18}$ (BCH, 2001):

- ZOLI - Zonas Livres: a lei original data de 1976 e foi reformada em 1998. Com administração do Estado Nacional, as zonas livres funcionam em nível municipal, o que converte todo o país em uma Zona Livre de facto. São exoneradas de todas as taxas relativas a impostos de importação e de exportação de mercadorias, assim como do Imposto sobre a Renda - IR - (Jenkins, Esquivel et Larrin, 1998), mas estão sujeitas à vigilância fiscal. Havia oito ZOLI com 46 empresas da CPTV (53,5\% do total de empresas) em 2002.

- ZIP - Zonas Industriais de Processamento para a Exportação: decretadas em abril de 1987 para atrair investimento externo, de propriedade e administração privada, localizadas em zonas geográficas autorizadas pelo Estado, sujeitas à vigilância fiscal, gozam de todas as exonerações das ZOLI. Eram 15 ZIP, nas quais operavam 99 empresas da CPTV $(78,6 \%)$ em 2002.

- RIT - Regime de Importação Temporária: datada de 1984, para promover as exportações e a subcontratação de empresas locais que exportem $10 \%$ de sua produção. Recebem todas as exonerações anteriores, exceto para exportações a outros países da América Central. Há isenção do IR somente nos 10 anos iniciais.

Cada uma das leis possui seu próprio regulamento e suas reformas, das quais têm sido objeto ao longo do tempo. Além destas, que são o marco jurídico para a promoção e aproveitamento da atividade maquiladora em Honduras, existem as normas para negociação de divisas.

\footnotetext{
${ }^{18}$ Um empresário hondurenho comentou a Gitli (1997): "temos três regimes legais para produzir a mesma calça para exportação".
} 
Algumas diferenças e muitas similaridades entre os regimes são apresentadas na tabela 2.5 a seguir:

Tabela 2.5 Principais incentivos por Regime de Exportação

\begin{tabular}{|c|c|c|c|}
\hline \multirow[b]{2}{*}{ Incentivos } & \multicolumn{3}{|c|}{ Regime de operação } \\
\hline & ZOLI & ZIP & RIT \\
\hline Propriedade das instalações & $\begin{array}{l}\text { Instalações e infra-estrutura } \\
\text { governamental. Inicialmente } \\
\text { localizadas nos portos, exceto } \\
\text { o município de Choloma. }\end{array}$ & $\begin{array}{l}\text { Parques industriais. } \\
\text { Instalações e infra-estrutura } \\
\text { empresas privadas locais } \\
\text { (maioria) localizadas perto das } \\
\text { grandes cidades. }\end{array}$ & $\begin{array}{l}\text { Instalações privadas, } \\
\text { localizadoa fora dos parques } \\
\text { industriais e das ZOLI. }\end{array}$ \\
\hline $\begin{array}{l}\text { Direito de importação de } \\
\text { matérias primas, } \\
\text { componentes, maquinaria e } \\
\text { equipamento }\end{array}$ & $100 \%$ isenção & $100 \%$ isenção & $100 \%$ isenção \\
\hline Impostos de exportação & $100 \%$ isenção & $100 \%$ isenção & 100\% isenção (lei de 1979) \\
\hline $\begin{array}{l}\text { Impostos sobre repatriação } \\
\text { de lucros }\end{array}$ & Isenção do IR & $\begin{array}{l}\text { Isenção de IR exceto nos casos } \\
\text { em que seja isentos nos países } \\
\text { de origem }\end{array}$ & Isenção de IR por 10 anos \\
\hline Vendas no mercado local & $\begin{array}{l}\text { Permitida se pagos direitos } \\
\text { tarifários e gravames } \\
\text { correspondentes }\end{array}$ & $\begin{array}{l}\text { Permitida quando não há } \\
\text { produção nacional, prévia } \\
\text { autorização do Ministério de } \\
\text { Economia e depois do } \\
\text { pagamento dos direitos } \\
\text { tarifários }\end{array}$ & Não permitido \\
\hline
\end{tabular}

Fonte: elaboração própria a partir de OIT (1996).

No caso das empresas que operam sob o sistema RIT, encontram-se em torno de 400 empresas que prestam serviços como sub-contratadas para as maquilas e também para as bananeiras, empresas produtoras/processadoras de camarão, Indústria Militar das Forças Armadas (de Honduras), exportadoras de café, açúcar, indústria gráfica, fósforos, madeiras manufaturadas, plásticos e outras (OIT, 1996).

Nesse mesmo ano, entraram em vigência as novas quotas para a exportação de vestuário para os Estados Unidos no marco da ampliação dos benefícios da IBC (Mazier et Castillo, 2002). 


\subsubsection{A indústria do vestuário: motor da maquila e m Honduras}

A indústria hondurenha do vestuário é de formação recente. Como a maioria dos setores industriais, datam da primeira metade do século XX. As indústrias têxtil e do vestuário atuais têm acentuada participação de grupos étnicos que recentemente fazem parte da população hondurenha, descendentes de árabes cristãos. O desenvolvimento destas indústrias esteve ligado, inicialmente, ao crescimento do poder aquisitivo da população e ao desenvolvimento urbano propiciado, na época, pelo auge das companhias bananeiras e das exportações de produtos agropecuários.

Nas décadas de 1980 e 1990, a indústria do vestuário, que já tinha vínculos com o mercado estadunidense ${ }^{19}$, se reestrutura para aproveitar as novas oportunidades que propiciavam as leis de produção compartilhada americanas ${ }^{20}$.

Realizaram-se estudos para criar-se, no país, estímulos e isenções especiais que complementam as leis dos Estados Unidos, como base para as estratégias de exportação na modalidade de maquilas. A indústria do vestuário tem sido um dos setores mais dinâmicos da economia hondurenha nas últimas décadas, como também em outros países da América Central e do Caribe. Em alguns itens, Honduras ocupa uma posição de destaque nas exportações de roupas aos Estados Unidos, notadamente naqueles produtos em que se especializa sua produção, como sutiãs.

Além da importância nas exportações, a indústria da maquila em Honduras é uma fonte de geração de emprego importante, crescendo de aproximadamente 8.000 no começo da década de 1980 para mais de 100.000 no início deste século.

\footnotetext{
${ }^{19}$ Empresas americanas tinham filiais, Joint ventures ou subcontratavam empresas hondurenhas para a sua produção (camisas Van Heusen e roupa íntima feminina Lovable, por exemplo).

${ }^{20}$ As leis de incentivo à produção compartilhada dos Estados Unidos eximem de impostos sobre a matéria-prima ou componentes de origem americana utilizados na montagem de produtos, os componentes em países com baixos salários e que serão reexportados para os Estado Unidos. As taxas de importação incidem somente sobre o valor agregado no país onde se realizou a montagem que normalmente equivale ao valor dos salários pagos por este serviço. Este assunto será aprofundado mais a frente.
} 
O valor agregado resultante em divisas para o país e a qualidade do emprego gerado são dois aspectos questionáveis que merecem atenção.

Atuam na Indústria Hondurenha da Maquila de Roupas - IHMR empresas de capital nacional e estrangeiro, com destaque para as de origem americana e asiática, entre outras. Existem algumas joint-ventures entre empresas de capital nacional com as estrangeiras e também de dois países estrangeiros que atuam no país.

Em 2000, a Indústria Hondurenha de Maquila de Roupas - IHMR era formada por 216 empresas e, em 2001 caiu para 208, segundo a Apparel Honduran Manufacturers Association (Asociación Hondureña de Maquiladores - AHMA). De acordo com o Banco Central de Honduras - $\mathrm{BCH}$, 64\% do total da indústria maquiladora hondurenha pertenciam à IHMR, divididas nas Zonas Livres - Zoli e nas Zonas de Processamento Industrial - ZPI.

Os primeiros investimentos internacionais ocorreram no setor agrícola e também nos minérios para a exportação sob a forma de "enclaves". O exemplo clássico é o da exportação de bananas, realizadas por companhias transnacionais de origem estadunidense. A experiência das maquilas mostra-se similar em certo grau: capital externo, exportação, incentivos diversos, pouco valor adicionado e contabilizado localmente, atividade intensiva em MDO, grande número de empregados, condições laborais, remunerações baixas e dificuldades para a sindicalização, Porém, como na época das bananeras, em muitos casos estas condições seriam melhores do que na maioria da indústria nacional.

Atualmente, a maioria dos parques industriais são propriedade privada de grupos econômicos hondurenhos preexistentes, consolidados na época das substituição de importações, os quais têm dirigido para as zonas francas privadas os recursos gerados em outras áreas como a construção (famílias Rosenthal, Larios e Arguello) e do 
vestuário (famílias Canahuati e Kattán). Somente uma ZOLI era totalmente coreana (Galaxy) e 25 \% da ZIP San Miguel é estadunidense (Walker, 1995 apud Gitli, 1997 - p. 41).

O número de empresas da maquila hondurenha cresceu rapidamente na década de 1980 e ainda no início da década de 1990. Embora no final o número de empresas mostre uma ligeira queda, as exportações continuam a crescer (menos aceleradamente). Supõese que este crescimento se deve ao aumento da produtividade e ao crescimento de algumas empresas, mais do que a novos investimentos. A origem do capital investido na maquila hondurenha por empresas é mostrado na tabela 2.6.

O investimento acumulado até 2001 alcançava US\$ 670,1 milhões de capital estrangeiro e US\$ 751,5 milhões de capital nacional (BCH, 2001).

O capital chega como investimento direto das empresas ou pela subcontratação de empresas locais. As empresas americanas são mais propícias a realizar joint-ventures com grupos nacionais e vimos que alguns grupos hondurenhos acabam nacionalizando a totalidade do capital, mantendo as relações comerciais.

É este um exemplo de estratégias de desenvolvimento de fornecedores, por um lado, e de aprendizado, pelo outro. Os novos investimentos são, em sua maioria, de capital nacional. Havia, em 2001, segundo o Diretório 2000-2001 da AHMA, joint-ventures de empresas hondurenhas com empresas dos seguintes países: Hong-Kong (1), México (1), Estados Unidos (3), entre empresas dos Estados Unidos e Guatemala (1) e 2 entre Estados Unidos e Coréia. Como se aprecia na tabela 2.10. 
Tabela 2.6 - Origem do capital das empresas maquiladoras em Honduras

(1994,1997, 2000.2001, participação \% e variação)

\begin{tabular}{|c|c|c|c|c|c|c|c|c|c|c|c|c|}
\hline ANO & \multicolumn{2}{|c|}{1994} & \multicolumn{2}{|c|}{1997} & \multicolumn{2}{|c|}{2000} & \multicolumn{2}{|c|}{2001} & \multicolumn{4}{|c|}{ Variação \% } \\
\hline Países & No. & $\%$ & No. & $\%$ & No. & $\%$ & No. & $\%$ & $\begin{array}{l}1994 \\
1997\end{array}$ & $\begin{array}{l}1997 \\
2000\end{array}$ & $\begin{array}{l}2000 \\
2001\end{array}$ & $\begin{array}{l}1994 \\
2001\end{array}$ \\
\hline $\begin{array}{l}\text { Estados } \\
\text { Unidos }\end{array}$ & 39 & 22,3 & 89 & 44,0 & 90 & 42,5 & 81 & 38,9 & 128,2 & 1,1 & $-10,0$ & 107,7 \\
\hline $\begin{array}{l}\text { Países } \\
\text { Asiáticos } \\
\end{array}$ & 48 & 27,4 & 64 & 31 & 52 & 24,5 & 52 & 25,0 & 33,3 & $-18,8$ & 0,0 & 8,3 \\
\hline Honduras & 88 & 50,3 & 42 & 21,0 & 52 & 24,5 & 64 & 30,9 & $-52,3$ & 23,8 & 23,1 & $-27,3$ \\
\hline Mistas & ND & $\mathrm{ND}$ & 4 & 2,0 & ND & $\mathrm{ND}$ & 6 & 2,9 & NA & NA & NA & $* 50,0$ \\
\hline $\begin{array}{l}\text { Outros } \\
\text { países }\end{array}$ & ND & ND & $\begin{array}{l}\text { Inglaterra } \\
\text { Grão Caim }\end{array}$ & an (2) & $\begin{array}{l}\text { Incluídos: } \\
\text { Rica } \\
\text { Guatemala } \\
\text { Panamá, } \\
\text { entre outro }\end{array}$ & osta & $\begin{array}{l}\text { Canadá (3 } \\
\text { Colômbia } \\
\text { Barbados }\end{array}$ & & & & & \\
\hline Subtotal & ND & ND & 4 & 2,0 & 18 & 8,5 & 5 & 2,4 & NA & 350,0 & $-72,2$ & $* 25,0$ \\
\hline TOTAL & 175 & 100 & 203 & 100 & 212 & 100 & 208 & 100 & 16,0 & 4,4 & $-1,9$ & 18,9 \\
\hline
\end{tabular}

Fonte: Elaboração própria com dados extraídosde: 1994: OIT 1996; 1997 e 2000: BCH 2001; 2001; AHMA 2001.

$\mathrm{ND}=$ Não disponível, NA= Não aplica, *= Variação de 1997 a 2001.

A participação das empresas de capital estadunidense aumentou e se estabilizou em torno dos $40 \%$ no final da década de 1990, enquanto a participação hondurenha diminuiu mas também se consolidou no final daquela década, chegando ao $30 \% \mathrm{em}$ 2001, aumentando novamente o número de empresas. A participação das empresas asiáticas parece tender a ficar em torno de $25 \%$. Nota-se que o número de empresas de capital exterior foi maior em 1997.

As empresas asiáticas instalaram-se na região para aproveitar as quotas não preenchidas e os benefícios de acesso ao mercado americano que desfrutam os países da América Central e do Caribe, aproveitando também os incentivos à exportação e ao investimento externo. Elas coordenam atividades de produção elou atuam como fornecedores de "Pacotes Completos". No caso de uma empresa de Taiwan entrevistada em Honduras, o grupo é quase verticalizado e para alocar suas operações construiu sua própria ZIP, o objetivo também é prestar serviços especializados às demais empresas maquiladoras. 
É interessante notar que a diminuição de empresas coreanas não se deu de forma tão acentuada como previsto em Gitli (1997) ${ }^{21}$ e o crescimento de maquilas de Hong-Kong em Honduras, a estabilidade do número de empresas de Cingapura e a queda dos outros países, são apresentados na tabela 2.7.

Tabela 2.7 - Investimento dos Países Asiáticos na IHMR por número de empresas

\begin{tabular}{|l|r|r|r|}
\hline País & $\mathbf{1 9 9 4}$ & $\mathbf{2 0 0 1}$ & Variação \% \\
\hline Coréia & 33 & 30 & $-9,1$ \\
\hline Taiwan & 6 & 4 & $-33,3$ \\
\hline Hong-Kong & 3 & 11 & 266,7 \\
\hline China & 2 & 1 & $-50,0$ \\
\hline Cingapura & 4 & 4 & 0,0 \\
\hline Total & $\mathbf{4 8}$ & 50 & 4,2 \\
\hline
\end{tabular}

2001.

A entrada e saída de empresas em Honduras é conhecida como efeito "golondrina" (andorinha em espanhol - Mazier et Castillo, 2002) e no Brasil é chamado de investimento do tipo "circo": quando não é mais rentável se levanta a lona à procura de outro público/mercado. Este comportamento é mais visível no caso das empresas menores. As saídas são mais aparentes quando há uma desaceleração do crescimento da atividade maquiladora no país.

De forma contrária, quando a maquila está em forte crescimento, é mais provável que floresçam pequenas empresas que se envolvam na produção subcontratada. Foi o que ocorreu em Honduras entre 1992 e 1994, quando houve um aumento das exportações da maquila (ver tabela 2.12). Também percebeu-se uma diminuição no tamanho médio das empresas: o número de trabalhadores passou de 408 para 207, segundo o estudo da OIT (1996) se deve a entrada de capital hondurenho, cujas empresas geralmente são menores e geram, em média, 168 postos de trabalho.

\footnotetext{
${ }^{21}$ Espera-se que as relações com a força de trabalho tenham sido harmonizadas, como manifestou um dirigente empresarial hondurenho.
} 
Em 2000 houve uma redução de empresas que operaram sob os regimes da maquila em relação a 1999. Foram abertas 13 novas empresas e fechadas 16, 1,4\% a menos $(\mathrm{BCH}$, 2001). Na tabela 5.2.6 também está registrada uma diminuição de 1,9\% no número de empresas, as maiores baixas têm sido das empresas asiáticas, de 1994 a 1997, e das estadunidenses, de 1997 a 2001. Este movimento é devido à mudança de nomes, razão social ou empresas que foram absorvidas por outras do mesmo regime fiscal, de acordo com o BCH (2001).

\subsubsection{Quais são os produtos fabricados e qual o mercado da Indústria Hondurenha de Maquila de Roupas - IHMR?}

Como mostrado acima, Honduras apresenta grande participação na produção regional de camisas, camisetas, roupa intima (cuecas e calcinhas) e sutiãs, além de um crescimento de capacidade na produção de jeans, mas sem ameaçar o México, país de origem de parte do capital de uma das empresas que os fabrica em Honduras.

Portanto, espera-se para estes produtos grandes escala de produção. Isto pode ser ilustrado ao analisar a diversidade de produtos e a especialização por plantas do diretório de empresas de 2000- 2001 da AHMA, nas tabelas apresentadas na continuação.

De acordo com a tabela 2.8, a seguir, as camisetas são o produto que mais empresas têm capacidade de produzir, seguido dos shorts, calças, camisas e roupa íntima. No caso das camisetas $34 \%$ das empresas são dedicadas exclusivamente a este produto; no caso das camisas, as plantas dedicadas a este produto constituem 54\%; na produção de roupa intima, $25 \%$; na de shorts, somente $2 \%$ (1 planta) e nenhuma das produtoras de calças é exclusiva. Estados Unidos, Honduras e Hong-Kong têm a maior e mais similar participação por empresas nesses produtos, exceto nas calças, em que Hong-Kong não participa. 
Assume-se grande capacidade de produção das empresas que fabricam sutiãs, pois elas são somente $11(5 \%)$ do total e é um produto de grande destaque nas exportações hondurenhas.

Tabela 2.8 -

Produtos fabricados na IHMR

\begin{tabular}{|c|c|c|c|c|c|}
\hline Produto & $\mathbf{N}^{\mathbf{0}}$ de empresas & $\%$ & Produto & $\mathbf{N}^{\mathbf{0}}$ de empresas & $\%$ \\
\hline Aventais & $\mathbf{3}$ & 1,4 & Blusas p/ mulher & $\mathbf{2 1}$ & 9,7 \\
\hline Sutiãs & $\mathbf{1 1}$ & 5,1 & Roupa Infantil & $\mathbf{1 6}$ & 7,4 \\
\hline Casacos & $\mathbf{2}$ & 0,9 & R. descartáveis & $\mathbf{1}$ & 0,5 \\
\hline Vestidos & $\mathbf{1 1}$ & 5,1 & $\mathbf{L u v a s}$ & $\mathbf{1}$ & 0,5 \\
\hline Jaquetas & $\mathbf{7}$ & 3,2 & Jeans & $\mathbf{1 6}$ & 7,4 \\
\hline Aventais de & $\mathbf{1}$ & 0,5 & Leggins & $\mathbf{2}$ & 0,9 \\
laboratório & & & & & $\mathbf{4}$ \\
\hline Sobretudos & $\mathbf{1}$ & 0,5 & Macacões & $\mathbf{4}$ & 6,5 \\
\hline Calças & $\mathbf{4 2}$ & 19,4 & Pijamas & $\mathbf{1 4}$ & 17,1 \\
\hline Robes & $\mathbf{6}$ & 2,8 & Camisas & $\mathbf{3 7}$ & 5,6 \\
\hline Shorts & $\mathbf{5 4}$ & 25,0 & Saias & $\mathbf{1 2}$ & 3,2 \\
\hline R. de dormir & $\mathbf{2}$ & 0,9 & R. esportiva & $\mathbf{7}$ & 0,5 \\
\hline Meias & $\mathbf{2}$ & 0,9 & Batas cirúrgicas & $\mathbf{1}$ & 4,2 \\
\hline Sweaters & $\mathbf{2}$ & 0,9 & Blusas moletom & $\mathbf{9}$ & 2,3 \\
\hline R. de banho & $\mathbf{1}$ & 0,5 & Calças moletom & $\mathbf{5}$ & 0,5 \\
\hline Camisetas & $\mathbf{9 5}$ & 44,0 & R. térmicas & $\mathbf{1}$ & 1,9 \\
\hline R. Intima & $\mathbf{2 4}$ & 11,1 & Uniformes & $\mathbf{4}$ & 0,5 \\
\hline R. de trabalho & $\mathbf{1}$ & 0,5 & Tinturarias & $\mathbf{1}$ & 0,5 \\
\hline Tecidos & $\mathbf{4}$ & 1,9 & Lavanderia Ind. & $\mathbf{1}$ & $\mathbf{1}$ \\
\hline Estamparia & $\mathbf{1}$ & 0,5 & Panos & $\mathbf{2 1 6}$ & 100 \\
\hline Linhas & $\mathbf{1}$ & 0,5 & TOTAL & & \\
\hline
\end{tabular}

Fonte: elaboração própria a partir de dados de AHMA 200-2001

* = 216 é o número de empresas constantes no diretório de empresas da AHMA 2000-2001, como algumas empresas fabricam mais de um produto, assim o número de empresas que realizam a atividade não deve somar-se para obter o total de empresas.

A tabela 2.9, a seguir, mostra o alto grau de especialização das empresas na IHMR, $44 \%$ delas são dedicadas a um só produto/serviço e 22\% com 2 linhas, sendo HongKong a origem das empresas com maior grau de especialização, 73 \%. Isto mostra, mais uma vez, que as empresa são fornecedoras especializadas inseridas nas CPTV. 
Tabela 2.9 - $\quad$ Diversidade de produtos ou de serviços diretamente ligada ao processo produtivo, por empresas agrupadas segundo país de origem do capital na IHMR (2000/2001)

\begin{tabular}{|c|c|c|c|c|c|c|c|c|c|c|c|c|c|c|c|}
\hline \multirow{2}{*}{$\begin{array}{c}\text { Empresas por País de } \\
\text { origem do capital }\end{array}$} & \multicolumn{15}{|c|}{ Número e $\%$ de produtos ou serviços realizados por empresa } \\
\hline & 1 & $\%$ & 2 & $\%$ & 3 & $\%$ & 4 & $\%$ & 5 & $\%$ & 6 & $\%$ & 7 & $\%$ & $\begin{array}{l}\text { Total- } \\
100 \%\end{array}$ \\
\hline Honduras & 15 & 35 & 8 & 19 & 5 & 12 & 1 & 2 & 5 & 12 & 2 & 5 & 2 & 5 & 43 \\
\hline Coréia & 10 & 34 & 7 & 24 & 2 & 7 & 5 & 17 & 2 & 7 & 1 & 3 & $\mathbf{0}$ & 0 & 29 \\
\hline Hong-Kong & 8 & 73 & $\mathbf{0}$ & 0 & 1 & 9 & 1 & 9 & $\mathbf{0}$ & 0 & 1 & 9 & $\mathbf{0}$ & 0 & 11 \\
\hline Cingapura & 1 & 25 & $\mathbf{0}$ & 0 & 1 & 25 & $\mathbf{0}$ & 0 & 2 & 50 & $\mathbf{0}$ & 0 & 0 & 0 & 4 \\
\hline Canadá & 2 & 67 & $\mathbf{0}$ & 0 & $\mathbf{0}$ & 0 & 1 & 33 & $\mathbf{0}$ & 0 & $\mathbf{0}$ & 0 & $\mathbf{0}$ & 0 & 3 \\
\hline Honduras/EUA & 2 & 67 & 1 & 33 & $\mathbf{0}$ & 0 & $\mathbf{0}$ & 0 & $\mathbf{0}$ & 0 & $\mathbf{0}$ & 0 & $\mathbf{0}$ & 0 & 3 \\
\hline EUA./Coréia & 2 & 100 & $\mathbf{0}$ & 0 & $\mathbf{0}$ & 0 & $\mathbf{0}$ & 0 & $\mathbf{0}$ & 0 & $\mathbf{0}$ & 0 & $\mathbf{0}$ & 0 & 2 \\
\hline Honduras/Hong Kong & 1 & 100 & $\mathbf{0}$ & 0 & $\mathbf{0}$ & 0 & $\mathbf{0}$ & 0 & $\mathbf{0}$ & 0 & $\mathbf{0}$ & 0 & $\mathbf{0}$ & 0 & 1 \\
\hline
\end{tabular}

Fonte: Elaboração própria com dados do diretório da AHMA 2000-2001.

A tabela 2.10 apresenta a pouca diversidade de produtos ofertados pelas empresas em conjunto, por país de procedência do capital.

Entre as firmas com operações em Honduras, joint-ventures ou que compram das empresas hondurenhas, estão as americanas Sara Lee Intimates, Hannes Choloma, Victoria Knits, VF de Honduras, Gildan Activewear, Confecções Perry, Jockey Honduras, Spencer's Honduras, JC Sewing Supply, Wrangler Honduras e Lovable de Honduras. As empresas Yantex, Quantex, da Zip Formoza, se destacam entre as asiáticas. Entre os mais importantes grupos hondurenhos estão INHDELVA e ELCATEX.

Chacón (2000) destaca a participação de Wrangler, Sara Lee e Fruit of the Loom, bem como a da Levi Strauss \& Co. nos investimentos da Bacia do Caribe, todas presentes em Honduras. 
Tabela 2.10 -

Produtos por país de origem das empresas maquiladoras em Honduras (2000-2001)

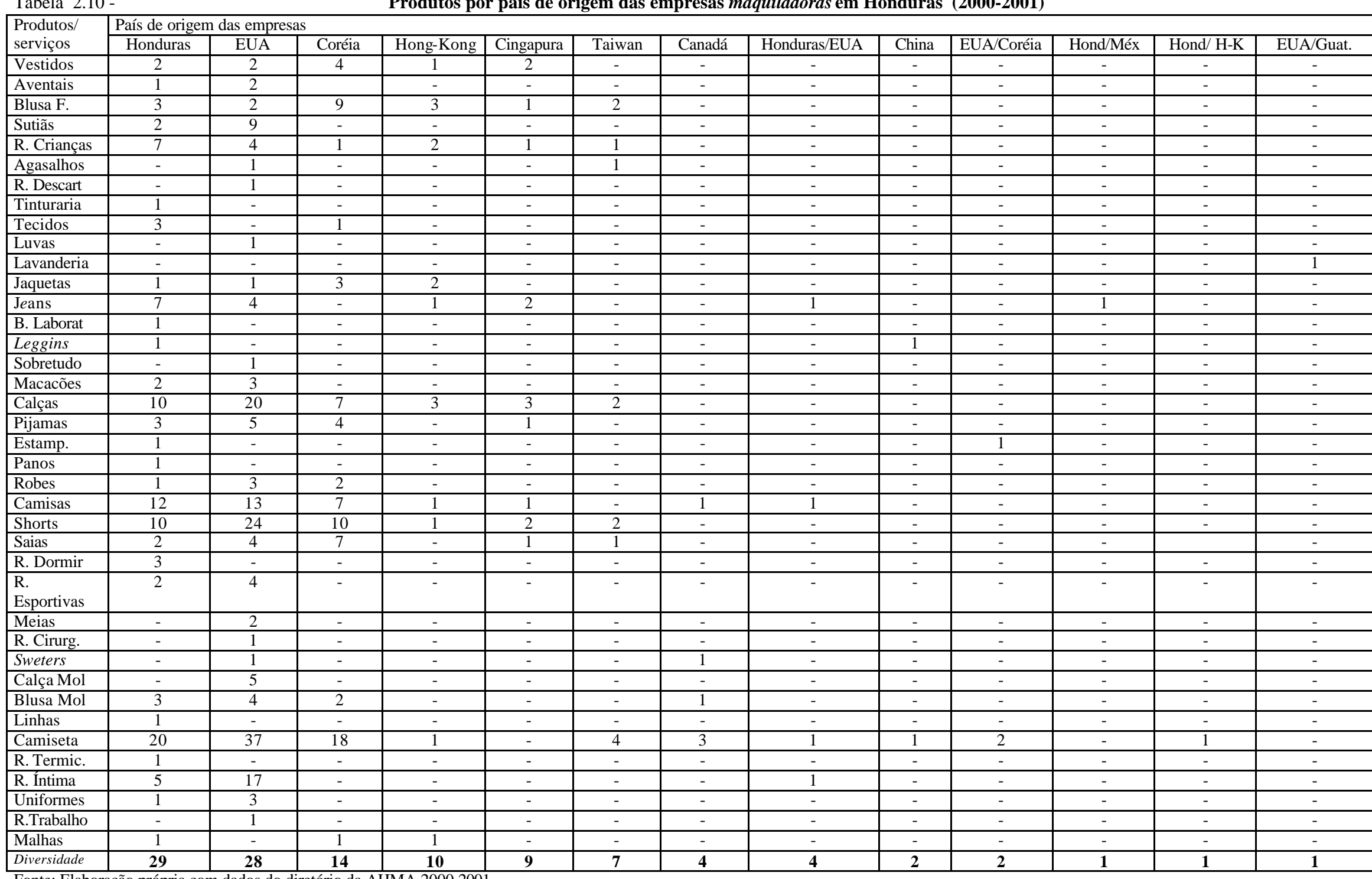


Sara Lee foi uma das empresas a implementar primeiro a estratégia de maquila na região, inicialmente em Costa Rica e República Dominicana. A produção se realiza por meio de um processo verticalmente integrado, no qual fios e tecidos são proporcionados por National Textiles ${ }^{22}$, os tecidos são também cortados nos Estados Unidos. Honduras, El Salvador e, eventualmente, Colômbia, segundo Chacón, são considerados lugares ideais para o crescimento de operações, antecipando a paridade com o NAFTA. Sara Lee é o maior produtor destes artigos no Caribe.

Fruit of the Loom, que tardiamente iniciou sua estratégia de maquila na região, e em Honduras somente em 1996, também utiliza a mesma forma de integração produtiva que a Sara Lee, de quem é um dos mais agressivos competidores. Talvez por isso, sugere Chacón (2000), a Fruit of the Loom se opôs fortemente à paridade da Iniciativa para os países da Bacia do Caribe - IBC com o NAFTA (The Wall Street Journal, 24,07,1997 e 08,08,1997, apud Chacón, 2000).

A Levi Strauss \& Co., que praticamente produz todas suas calças Dockers na região do Caribe, por sua vez, é uma das empresas que mais têm apoiado a IBC, considerando-a como um catalisador para as mudanças estratégicas da empresa, trasladando grande parte da produção da Ásia para a região, onde a utilização de tecidos e outros componentes é muito maior, assim preservando a competitividade da indústria estadunidense (USITC, 1998 apud Chacón, 2000).

As ações das empresas estadunidenses para a IBC são integradas. Por exemplo, Dupont instalou, em Honduras, um escritório da sua divisão de Global Sourcing para servir a seus clientes, bem como as seus fornecedores. Esta atitude é parte da sua estratégia para evitar a concorrência de similares mais baratos da Lycra (Bair et Gereffi, 2002).

\footnotetext{
${ }^{22}$ Em 1998, a Sara Lee anunciou um processo de desverticalização nos segmentos de fiação e tecelagem, que atingia a National Textiles.
} 
As empresas da IMRH produzem praticamente de forma exclusiva para a exportação ao mercado norte-americano ${ }^{23}$, devido aos incentivos e isenções das leis de importação daquele país.

De acordo com dados da CEPAL-ONU, nos produtos classificados nos itens de vestuário (842 a 846 da Standard Apparel Trade Classification - SITC), Honduras ocupou, em 2000, o $4^{\mathrm{o}}$ lugar em exportações para o mercado norte-americano ${ }^{24}$, com US\$ 78,2 milhões, aumentando sua participação de 0,2 para $4 \%$ (variação de $2.206 \%$ ) de 1985 a 2000. No mesmo período, a participação desses itens nas exportações do país passou de 5,7 para 78,2 \%, significando uma variação de 1.277 $\%$ (Mortimore, 2002).

A análise de dados é desafiante: são os referentes à exportações da maquila e em geral de produtos da CPTV hondurenha. As bases a que se teve acesso não separam a maquila dos números totais das exportações ${ }^{25}$. Por isso, utilizamos para a nossa análise, prioritariamente, dados do Banco Central de Honduras - $\mathrm{BCH}$, da Associação Hondurenha de Maquiladores - AHMA, da Fundação para o Investimento e Desenvolvimento das Exportações de Honduras - FIDE, assim como de outros estudos realizados em nível centro-americano.

Assim, a tabela 2.11 apresenta o crescimento das exportações entre 1983 e 2001, estes dados incluem todas as exportações da CPTV, inclusive as da maquila. A tabela 2.12 é exclusiva dos produtos da maquila e, conseqüentemente, apresenta valores menores. Como os valores de exportação somente coincidem, em ambas as tabelas, para os anos de 1994 e de 2001, considera-se importante destacar os valores

\footnotetext{
${ }^{23}$ Já para outros produtos o mercado de exportação é mais variado, a América do Norte continua sendo o principal comprador, tomando como exemplo o ano de 1998, exportou-se ao mercado norte-americano US\$632,8 milhões; o segundo lugar coube à Europa, com US\$ 456,4 milhões; a América Central e o restante da América Latina compraram US\$262,3 e US\$ 78,2 milhões, respectivamente; o resto do mundo somente consumiu US\$ 36,6 milhões em produtos hondurenhos. Por países, e em ordem de importância, os principais importadores são: Estados Unidos (US\$ 626,3 milhões ), Alemanha (US\$124,4 milhões), Bélgica (US\$ 90,7 Milhões), Guatemala (US\$ 88,7 Milhões), El Salvador (US\$ 83,3 Milhões), Japão (US\$ 66,7 Milhões), Nicarágua (US\$ 65,7 Milhões), Espanha (US\$ 44,3 Milhões), Inglaterra (US\$ 32,9 Milhões), Itália (US\$ 30,9 Milhões) e Brasil, que unicamente importa US\$ 0,2 Milhões de produtos hondurenhos $(\mathrm{BCH}, 2002)$.

${ }^{24}$ Neste caso incluem-se Estados Unidos e Canadá.

${ }^{25}$ O World Trade Analizer é um exemplo.
} 
similares da variação percentual das exportações totais e das maquilas no período, que foi de $275,2 \%$ no primeiro caso e de $262,9 \%$ no caso das maquilas.

Tabela 2.11 - Exportações de têxteis e vestuário hondurenhos para os Estados Unidos (1983-2001)

\begin{tabular}{|l|c|c|c|c|c|c|l|l|l|}
\hline Exportações & $\mathbf{1 9 8 3}$ & $\mathbf{1 9 8 6}$ & $\mathbf{1 9 9 0}$ & $\mathbf{1 9 9 4}$ & $\mathbf{1 9 9 8}$ & $\mathbf{2 0 0 1}$ & $\begin{array}{l}\text { Variação \% } \\
\mathbf{1 9 8 3 - 1 9 9 0}\end{array}$ & $\begin{array}{l}\text { Variação \% } \\
\mathbf{1 9 9 0 - 1 9 9 4}\end{array}$ & $\begin{array}{l}\text { Variação \% } \\
\mathbf{1 9 9 4}-2001\end{array}$ \\
\hline (US\$ milhões) & 20 & 32 & 113 & 650 & 1.905 & 2.438 & 565 & 476,9 & 275,2 \\
\hline
\end{tabular}

Fonte: Extraída de Bair et Gereffi (2002). Compilada das estatísticas oficiais do U.S. Department of Commerce, International Trade Administration, Office of Textiles and Apparel Importações para o consumo, valor alfandegário.

Tabela 2.12 -

Exportações da IHMR para os Estados Unidos (1994-2001)

\begin{tabular}{|l|l|l|l|l|l|l|l|l|l|}
\hline Exportações & $\mathbf{1 9 9 4}$ & $\mathbf{1 9 9 5}$ & $\mathbf{1 9 9 6}$ & $\mathbf{1 9 9 7}$ & $\mathbf{1 9 9 8}$ & $\mathbf{1 9 9 9}$ & $\mathbf{2 0 0 0}$ & $\mathbf{2 0 0 1}$ & $\begin{array}{l}\text { Variação \% } \\
\mathbf{1 9 9 4 - 2 0 0 1}\end{array}$ \\
\hline (US\$ milhões) & 646,0 & 921,1 & $1.219,5$ & $1.659,0$ & $1.855,1$ & $2.158,3$ & $2.361,4$ & $2.344,2$ & 262,9 \\
\hline
\end{tabular}

Fonte: Dados do IDS/OEC In Honduran Apparel Manufacturers Association. "Apparel Industry Statistics 2001”

Tabela 2.13 - Balanço comercial têxtil e de vestuário hondurenho (US\$ milhões)

\begin{tabular}{|c|c|c|c|}
\hline & 1999 & 2000 & 2001 \\
\hline Exportações FOB (não incluímaquila ) & 3,9 & 7,0 & 6,1 \\
\hline Importações CIF (não incluímaquila) de acordo com SAC* & 85,9 & 80,9 & 60,1 \\
\hline Saldo sem maquila & $-82,0$ & $-73,9$ & $-54,0$ \\
\hline Exportações da Maquila & $2.158,3$ & $2.361,4$ & $2.344,2$ \\
\hline Saldo do Balanço Geral incluindo exportações da maquila & $2.076,3$ & $2.287,5$ & $2.290,2$ \\
\hline
\end{tabular}

Fonte: Elaboração própria a partir de dados do BCH - Subgerencia de Estudios Económicos; Honduras en cifras 1999-2001 e da AHMA 2001. * SAC=Sistema Arancelário Centroamericano

Com os valores de exportação e importação que não incluem a maquila na tabela 2.13, fica claro que o comércio exterior de têxteis e vestuário, que não se rege pelos regimes tarifários da maquila, é bem menor do que o volume das exportações da maquila, embora deficitário. Supõe-se que essas importações suprem o mercado interno. Algumas delas referem-se a insumos complementares para a produção das maquilas, feitas por fornecedores de fora dos Estados Unidos, provavelmente por empresas locais ou asiáticas operando no país. A balança comercial só é positiva ao somar as exportações da maquila. 
As maquiladoras de exportação não concorrem pelo mercado interno com a indústria local, pois além do fato de que os incentivos foram criados para encorajar a exportação e para comercializar seus produtos no mercado interno, a Indústria Hondurenha de Maquila, além de pagar as devidas taxas de importação e outras taxas que regulam o comércio e a produção local, também deve solicitar autorização de acordo com o regime de maquila sob o qual atuam.

A maior parte das importações de roupa provém da América Central. Em seguida está a parcela que ingressa na região através do Panamá, que atua como grande centro distribuidor das marcas famosas e também de produtos asiáticos sem marca reconhecida. O mercado interno é, ademais, afetado pelo contrabando e pelas importações de roupas americanas usadas, que inicialmente vinham como doação para ações de caridade de igrejas ou em épocas de calamidade por desastres naturais. Este tipo de importações afeta fortemente a pequena e média indústria local.

\subsubsection{Valor agregado das exportações da Indústria Hondurenha de Maquila de Roupas - IHMR}

Em 1980, o valor agregado da IHMR representava menos do $1 \%$ das exportações de bens e serviços e em 1995 constituía uma quinta parte do total exportado (Torres, 1997). O valor agregado é o resultante das divisas que ficam no país, subtraindo-se, do valor total das exportações, os insumos comprados localmente, assim como todos os gastos realizados no país - o valor do aluguel de instalações e equipamentos, outros serviços e, principalmente, salários.

O Valor Bruto de Produção inclui: (a) Consumo Intermediário - aluguel de edifícios, arrendamento de maquinaria e equipamento, combustíveis e lubrificantes, energia elétrica e água, gastos em transporte de pessoal, gastos com serviços de profissionais, manutenção e reparos, seguros (excluindo seguros de vida), serviços vários, portuários e alfandegários, telefone, fax, e correio; (b) salários, benefícios e doações, o Instituto Hondurenho de Seguridade Social, Instituto Nacional de Formação 
Profissional, juros e taxas indiretas. A evolução do Valor Agregado, de 1994 a 2001, é mostrada com valores em dólares na tabela 2.14 a seguir:

Tabela 2.14 - $\quad$ Evolução do valor agregado da maquila gerado no país (US\$ milhões/ano)

\begin{tabular}{|l|l|l|l|l|l|l|l|l|l|}
\hline & $\mathbf{1 9 9 4}$ & $\mathbf{1 9 9 5}$ & $\mathbf{1 9 9 6}$ & $\mathbf{1 9 9 7}$ & $\mathbf{1 9 9 8}$ & $\mathbf{1 9 9 9}$ & $\mathbf{2 0 0 0}$ & $\mathbf{2 0 0 1} *$ & $\begin{array}{l}\text { Var.\% } \\
\mathbf{1 9 9 4 - 2 0 0 0}\end{array}$ \\
\hline PIB $^{\mathbf{2 6}}$ Geral & 26.862 & 37.507 & 47.774 & 61.084 & 70.438 & 77.095 & 87.523 & 89.711 & $\mathbf{2 2 5 , 8 2}$ \\
\hline V. Agregado da IHMR ** & $\mathbf{1 . 7 4 8}$ & $\mathbf{2 . 4 9 1}$ & $\mathbf{3 . 5 5 4}$ & $\mathbf{5 . 1 6 9}$ & $\mathbf{6 . 3 7 5}$ & $\mathbf{7 . 8 4 6 , 7}$ & $\mathbf{8 . 0 0 5 , 4}$ & $6.884,3$ & $\mathbf{3 5 7 , 9 7}$ \\
\hline $\begin{array}{l}\text { V. Agregado da IHMR } \\
\text { Como \% do V.A. Nacional }\end{array}$ & $6,5 \%$ & $6,64 \%$ & $7,44 \%$ & $8,47 \%$ & $10,05 \%$ & $10,18 \%$ & $9,15 \%$ & $7,67 \%$ & $\mathbf{4 0 , 7 7}$ \\
\hline
\end{tabular}

Fonte: Elaborado a partir de dados do BCH e dados do IDS, em AHMA, 2001.

*dados previstos. **somente dados das exportações 807.

Além da diversificação da atividade "maquiladora", O BCH estimava, para 20012002 que o valor agregado bruto gerado cresceria em torno de $10,7 \%$, e a geração de emprego, em 2,5\%. A tabela 2.17 mostra a evolução e o cálculo feito pelo $\mathrm{BCH}$ em "Lempiras" 27 , onde fica aparente que o pagamento de salários é o principal item desta conta de produção.

\subsubsection{Produtividade, emprego e salários na Indústria Hondurenha de Maquila de Roupas - IHMR}

Segundo o estudo de Buitelaar (2000), os países da região centro-americana e da República Dominicana, desde a vigência do NAFTA, obtiveram um aumento da produção, em média de 19\%, junto com a contenção dos custos de produção. As empresas melhoraram a sua eficiência produtiva (produzir mais com os mesmos insumos), sem afetar sua margem de lucro. Embora tenha havido investimentos na modernização, foi a força de trabalho que mais contribuiu, aumentando sua produtividade sem receber o correspondente aumento real de salários.

No referente a Honduras, em 1990 a IMH empregava 9.030 pessoas e, em 2000, eram 106.530, como se aprecia na tabela 2.15. Só no ano 2000 foram gerados 3.259

\footnotetext{
26 De acordo com Mazier et Castillo, a participação da maquila entre todos os demais setores indústrias na formação do PIB nacional foi em média de 16,5 \%, de 1990 a 1999.

${ }^{27}$ Moeda nacional de Honduras.
} 
novos empregos, um crescimento de 3,2 \%. Esses números apontam para a importância do setor privado nas maquilas, sendo que o emprego nas ZIP é quase o dobro do gerado pelas ZOLI desde 1996.

Tabela 2.15 - $\quad$ Emprego gerado pela maquila na década de 1990 ( No. de pessoas)

\begin{tabular}{|r|r|r|r|r|}
\hline Ano & ZIP & ZOLI & Total & Variação relativa \\
\hline $\mathbf{1 9 9 0}$ & 3.037 & 5.993 & $\mathbf{9 . 0 3 0}$ & \\
\hline $\mathbf{1 9 9 1}$ & 6.594 & 13.527 & $\mathbf{2 0 . 1 2 1}$ & 122,8 \\
\hline $\mathbf{1 9 9 2}$ & 11.961 & 15.626 & $\mathbf{2 7 . 2 1 7}$ & 35,3 \\
\hline $\mathbf{1 9 9 3}$ & 16.424 & 16.907 & $\mathbf{3 3 . 3 3 1}$ & 22,5 \\
\hline $\mathbf{1 9 9 4}$ & 23.287 & 19.254 & $\mathbf{4 2 . 5 4 1}$ & 27,6 \\
\hline $\mathbf{1 9 9 5}$ & 35.401 & 19.594 & $\mathbf{5 4 . 9 9 5}$ & 29,3 \\
\hline $\mathbf{1 9 9 6}$ & 43.076 & 21.974 & $\mathbf{6 5 . 9 5 0}$ & 19,9 \\
\hline $\mathbf{1 9 9 7}$ & 57.028 & 26.436 & $\mathbf{8 3 . 4 6 4}$ & 26,6 \\
\hline $\mathbf{1 9 9 8}$ & 66.261 & 32.644 & $\mathbf{9 8 . 9 0 5}$ & 18,5 \\
\hline $\mathbf{1 9 9 9}$ & 66.834 & 36.437 & $\mathbf{1 0 3 . 2 7 1}$ & 4,4 \\
\hline $\mathbf{2 0 0 0}$ & 72.288 & 34.242 & $\mathbf{1 0 6 . 5 3 0}$ & 3,2 \\
\hline
\end{tabular}

Fonte: BCH 2001, /P: preliminar.

O custo, a MDO e o valor do salário anual dos trabalhadores das maquilas cresceu, segundo a tabela 2.16, com dados da AHMA. Este item é o principal na constituição do valor agregado, que representou em 2000: 61,9\% do Valor Bruto de Produção e 92,7 \% do Valor Agregado Bruto, como mostra a tabela 2.17.

Tabela 2.16 - Evolução dos salários nas maquilas de roupa hondurenhas (US\$/ano)

\begin{tabular}{|c|c|c|c|c|c|c|}
\hline Ano & 1996 & 1997 & 1998 & 1999 & 2000 & 2001 \\
\hline Salário mínimo oficial com bônus aplicáveis & $1.302,10$ & $1.692,01$ & $1.893,01$ & $2.118,82$ & $2.151,02$ & $2.441,31$ \\
\hline Salário M. oficial com colaterais e bônus aplicáveis & $1.963,69$ & $2.551,73$ & $2.854,85$ & $3.195,40$ & $3.234,95$ & $3.681,73$ \\
\hline Salário hora* & 0,62 & 0,80 & 0,90 & 1,00 & 1,02 & 1,16 \\
\hline
\end{tabular}

Fonte: Elaborado com dados da AHMA 2001. * Calculado a partir de 12 meses/ano, 4 semanas/mês, 44 horas/semana trabalhadas. 
Tabela 2.17 - $\quad$ Produção das empresas maquiladoras sob os regimes de ZIP e ZOLI em Honduras

1990 - 2000 p/(Em milhões de Lempiras à época)

\begin{tabular}{|c|c|c|c|c|c|c|c|c|c|c|c|}
\hline \multirow[t]{2}{*}{ SEGMENTOS } & \multicolumn{11}{|c|}{ VALORES / ANO } \\
\hline & 1990 & 1991 & 1992 & 1993 & 1994 & 1995 & 1996 & 1997 & 1998 & 1999 & $2000 \mathrm{pl}$ \\
\hline A. VALOR BRUTO DE PRODUÇÃO (B+C) & 63,3 & 183,0 & 342,9 & 530,2 & 813,9 & $1.258,5$ & $2.016,6$ & $3.355,8$ & $5.336,8$ & $6.418,6$ & $8.184,7$ \\
\hline B. CONSUMO INTERMEDIÁRIO & 23,1 & 53,2 & 120,0 & 191,0 & 331,2 & 416,0 & 619,7 & $1.120,9$ & $1.844,8$ & $2.343,3$ & $2.721,7$ \\
\hline Aluguel de edifícios & 3,4 & 11,9 & 24,4 & 42,6 & 75,2 & 78,0 & 130,1 & 296,6 & 361,3 & 448,8 & 532,3 \\
\hline Arrendamento de maquinaria e equipamento & 0,2 & 0,4 & 0,5 & 0,8 & 1,7 & 2,6 & 2,1 & 6,0 & 8,5 & 11,5 & 14,1 \\
\hline Combustíveis e lubrificantes & 0,5 & 0,9 & 1,7 & 5,0 & 10,8 & 14,2 & 19,0 & 32,7 & 45,9 & 80,0 & 92,3 \\
\hline Energia elétrica e água & 2,2 & 6,8 & 19,4 & 27,4 & 46,4 & 80,0 & 112,9 & 185,6 & 251,1 & 285,4 & 357,1 \\
\hline Gastos em transporte de pessoas & 1,6 & 2,4 & 4,9 & 9,5 & 14,4 & 25,3 & 30,0 & 54,2 & 41,6 & 50,7 & 64,7 \\
\hline Honorários profissionais & 0,5 & 0,8 & 0,9 & 2,9 & 3,6 & 6,5 & 7,6 & 12,7 & 23,5 & 62,7 & 73,8 \\
\hline Manutenção e reparações & 1,0 & 3,2 & 7,5 & 9,3 & 16,3 & 23,3 & 39,1 & 66,0 & 116,5 & 135,3 & 187,0 \\
\hline Seguros (excluindo de vida) & 0,5 & 0,7 & 1,1 & 3,2 & 9,9 & 10,0 & 11,6 & 15,4 & 18,0 & 30,3 & 49,7 \\
\hline Serviços contratados & 8,0 & 10,1 & 18,0 & 29,3 & 38,2 & 27,9 & 59,7 & 134,3 & 224,9 & 370,4 & 443,8 \\
\hline Serviços portuários e aduaneiros & 0,4 & 1,5 & 3,5 & 5,5 & 8,0 & 8,2 & 11,1 & 20,8 & 38,6 & 44,3 & 50,3 \\
\hline Telefone, fax e correio & 0,7 & 5,8 & 8,6 & 12,4 & 25,4 & 28,2 & 42,3 & 60,1 & 78,0 & 86,1 & 91,5 \\
\hline Outros gastos & 4,1 & 8,7 & 29,5 & 43,1 & 81,3 & 111,8 & 154,2 & 236,6 & 636,9 & 737,8 & 765,1 \\
\hline C. VALOR AGREGADO BRUTO p.m. & 40,2 & 129,8 & 222,9 & 339,2 & 482,7 & 842,5 & $1.396,9$ & $2.234,9$ & $3.492,0$ & $4.075,3$ & $5.463,0$ \\
\hline Salários & 31,1 & 116,5 & 205,6 & 316,4 & 432,5 & 758,2 & $1.282,5$ & $2.058,5$ & $3.188,2$ & $3.683,5$ & $5.065,9$ \\
\hline Benefícios vários e doações & 1,0 & 2,1 & 3,2 & 4,4 & 5,5 & 9,5 & 11,7 & 16,2 & 32,6 & 18,5 & 22,8 \\
\hline $\begin{array}{l}\text { IHSS-Instituto de Seguridade Social e INFOP-Instituto Hondureño de } \\
\text { Formación Profesional }\end{array}$ & 6,9 & 8,5 & 10,3 & 13,4 & 26,5 & 44,6 & 62,5 & 98,6 & 127,5 & 162,4 & 203,3 \\
\hline Juros & 0,3 & 0,1 & 1,6 & 2,5 & 15,4 & 26,3 & 35,2 & 52,2 & 121,4 & 172,6 & 140,2 \\
\hline Impostos indiretos & 0,9 & 2,6 & 2,2 & 2,5 & 2,8 & 3,9 & 5,0 & 9,4 & 22,3 & 38,3 & 30,8 \\
\hline
\end{tabular}

Fonte: BCH, 2001, p/ Preliminar. 


\subsubsection{Situação da mulher trabalhadora nas maquilas hondurenhas}

Desde o início houve predominância de mulheres na IHM porque a maioria das empresas se dedicam à confecção de vestuário. Em 2000, dos 106.530 trabalhadores, $63,5 \%$ eram mulheres e $36,5 \%$ homens, como mostra a tabela 2.18 .

Tabela 2.18 - Distribuição do emprego por gênero na maquila hondurenha

\begin{tabular}{|c|c|c|c|c|c|c|}
\hline & \multicolumn{3}{|c|}{ RECURSOS HUMANOS OCUPADOS } & \multirow{2}{*}{$\begin{array}{l}\text { Variação } \\
\text { Relativa }\end{array}$} & \multicolumn{2}{|c|}{$\%$} \\
\hline Anos & Feminino & Masculino & Total & & Feminino & Masculino \\
\hline 1995 & 37.736 & 17.259 & 54.995 & 29,3 & 68,6 & $\overline{31,4}$ \\
\hline 1996 & 46.804 & 19.146 & 65.950 & 19,9 & 71,0 & 29,0 \\
\hline 1997 & 59.639 & 23.825 & 83.464 & 26,6 & 71,5 & 28,5 \\
\hline 1998 & 72.523 & 26.382 & 98.905 & 18,5 & 73,3 & 26,7 \\
\hline 1999 & 73.035 & 30.236 & 103.271 & 4,4 & 70,7 & 29,3 \\
\hline $2000^{p}$ & 67.677 & 38.853 & 106.530 & 3,2 & 63,5 & 36,5 \\
\hline
\end{tabular}

No quadro anterior observa-se o aumento da participação masculina devido à incorporação de novas indústrias com atividades maquiladoras distintas da confecção, o que tem permitido ampliar a oferta de emprego para os homens. Entre as novas atividades da maquila estão: a indústria de transformação da madeira, de autopeças e de componentes elétricos.

Mazier et Castillo (2002) encontraram, em sua pesquisa, os seguintes resultados: das 214 mulheres entrevistadas, 58,9\% (126) eram solteiras e 81,4\% (172) tinham menos de 30 anos. Analisadas por idade, 13,1\% (28) tinham de 15 a 19 anos, 43,5\% (93) tinham de 20 a 24 anos, $23,8 \%$ (51) tinham de 25 a 29 anos e as restantes 19,6\% (42) tinham 30 anos ou mais.

Houve, ainda, casos documentados de abusos e de más condições de trabalho, baixos salários, excesso de carga de trabalho (metas de produção e tempo), falta de pagamento 
de horas extras e repressão de sindicalização. Moncada (1995) realizou uma ampla e importante pesquisa a respeito. Entre os mais famosos estão os depoimentos de Lesly Margoth Rodriguez (em 1994) e Wendy Yamileth Diaz (em 1995) ante o Senado dos Estados Unidos (Diários hondurenhos: La Tribuna, El Heraldo, El Tiempo e La Prensa em 10 e 23 de novembro de 1994 apud Fundación Freidrich Ebert, 1998). Estas iniciativas deram lugar a vários movimentos de monitoração independente, fóruns e contratos para melhorar as condições de trabalho e a imagem da IHMR, principalmente pressionadas pelas contratantes ou clientes americanas.

Segundo a pesquisa de Mazier et Castillo, muitos dos problemas ainda subsistiam cinco anos depois. Este tipo de problema aparentemente foi ou é mais comum nas empresas coreanas $^{28}$. Já nas empresas estadunidenses há a preocupação de se manter uma política de relações trabalhistas "sustentável" a longo prazo, por causa, principalmente, da sensibilidade do consumidor norte-americano às denuncias de ONGs e aos empregos exportados. A preocupação deve-se também ao grau de organização e lobby dos trabalhadores norte-americanos que tomam proveito destas denúncias. O poder de boicote da sociedade americana (principalmente estudantes e trabalhadores organizados do setor) a produtos cujas marcas e imagens corporativas constituem seu maior valor agregado é outro fator que influencia a política das empresas dos EUA, que não podem permitir que valores intangíveis tornem-se vulneráveis no mercado, porque seus fornecedores não cumprem com os direitos do trabalhador (Gitli,1997).

Na época da pesquisa de campo da tese, alguns dos empresários e executivos de projetos/programas de desenvolvimento industrial entrevistados destacaram que as relações trabalhistas melhoraram e que as maiores empresas, tanto internacionais como nacionais que trabalham para clientes com nomes de marca reconhecida no exterior, têm melhorado as condições de trabalho de seus empregados. Muitas vezes as "maquilas nacionais", que trabalham para o mercado interno (não necessariamente maquilas no

\footnotetext{
${ }^{28}$ As empresas coreanas têm antecedentes de conflitos no mundo inteiro (OIT, 1996 a: 31 in Gitli, 1997).
} 
sentido da definição jurídica e econômica) ou subcontratadas pelas que estão conectadas ao exterior, teriam maiores problemas deste tipo.

Na pesquisa de campo somente se entrevistou um ex-trabalhador das maquilas, hoje microempresário da confecção. Para Fernández(2000, apud Mazier et Castillo, 2002), de 1997 a 2000, as condições de trabalho nas empresas têm melhorado. Porém, a qualidade e estabilidade dos empregos continuam sendo desfavoráveis por causa da não observância dos direitos trabalhistas e da alta rotatividade da MDO. Apesar das melhorias, a sindicalização é difícil e encontra barreiras no empresariado, embora as leis garantam os direitos dos trabalhadores. O estado se vê inoperante na supervisão do cumprimento destas leis, em muitos casos devido à sua dficuldade de gerar empregos e melhores oportunidades e de proporcionar melhores condições de vida aos hondurenhos, tendo, assim, que ofertar benefícios para o capital estrangeiro e nacional realizarem essas funções. Não é demais repetir que esta situação não é única na América Latina, sendo mais raras as exceções, e que a concorrência por esse tipo de investimento é grande.

Apesar disso, entre 1995 e 2001 surgiram 46 sindicatos, dos quais 50\% estão ativos na zona norte, devido às suas mobilizações. Apesar de sua recente fundação, $40 \%$ deles têm alcançado trunfos nas negociações de contratos coletivos.

Outro dado interessante na pesquisa de Mazier et Castillo (2002) é referente à permanência no trabalho. Somente 6,1\% (13) tinham menos de dois meses no serviço ainda período de experiência; 27,6\% (59) tinham de 2 meses a 1 ano de trabalho na empresa; 24,8\% (53) tinham de 1 a 2 anos de trabalho na mesma empresa; 33\% (71) de 2 a 5 anos e 8,4\% (18) tinham mais de 5 anos. A maioria delas (98) já tinha experiência em outras empresas maquiladoras de outras regiões do país e o restante estava em seu primeiro emprego numa maquiladora. 
Embora na região central, onde se realizou a pesquisa, as maquilas sejam mais recentes do que na costa norte, onde encontram-se a maioria e as primeiras maquiladoras, não nos parece que nelas havia um alto grau de rotatividade. Isto concorda com a preocupação, encontrada na nossa pesquisa, das maquilas reterem ou contratarem pessoal com experiência. Provavelmente a rotatividade era maior quando começou a IHMR.

As autoras encontraram, em relação a escolaridade das 214 entrevistadas, que 4,7\% (10) tinham nível primário incompleto, 45,3 \% (96) tinham nível primário completo, 33,6\% (14) tinham iniciado o nível secundário, 16,4\% (35) tinham nível secundário completo e $0,5 \%$ (1) cursava o nível superior. Desse total, 18 pessoas $(8,4 \%)$ continuavam estudando, sendo maior o número das que continuam a estudar entre as que têm de 20 a $24 \operatorname{anos}(11)$.

Comparando com dados de 1995, na pesquisa realizada por Kennedy et Cardona (1995), que entrevistaram 100 trabalhadoras de maquilas da região norte, encontraram $4 \%$ que eram analfabetas, 56\% tinham realizado estudos de nível primário e $40 \%$ tinham realizado estudos secundários.

Percebe-se, então, um aumento da escolaridade de nível médio e universitário, enquanto proporcionalmente diminui o de pessoas que somente realizaram estudos de educação primária e que o analfabetismo na segunda amostra não existia. Isto não pode ser conclusivo, desde que tratam-se de empresas e regiões diferentes. Nas nossas entrevistas, porém, foi ressaltada a necessidade de contratar pessoal mais qualificado.

A tabela 2.19, na página seguinte, apresenta os requerimentos trabalhistas aos quais devem se ater as empresas e os trabalhadores da IHMR, divulgados por FIDE em 2002. 


\subsubsection{Ambiente institucional da Indústria Hondurenha de Maquila de Roupas - IHMR}

A maquila, apesar de polêmica, representa para o país um símbolo de modernidade industrial. É interessante como os empreendedores locais utilizam o termo "maquila" para muitas atividades industriais, embora não utilizem a montagem ou a subcontratação e muito menos a exportação. Por outro lado, para a maioria da população, maquila é quase sinônimo das indústrias têxteis e da confecção.

Tabela 2.19 -

\section{Requerimentos Trabalhistas na IHMR}

$90 \%$ da força de trabalho deve ser hondurenha ou o equivalente a $85 \%$ da planilha.

Benefícios trabalhistas

- Bônus de assistência, 1 dia de salário por semana

- $13^{\circ}$ e $14^{\circ}$ salários (dezembro e junho)

- Seguro Social

- Bônus escolar

\section{Jornada de Trabalho}

- Dia: 5:00 às 19:00 hs.

- Noite: 19:00 às 5:00 hs.

- Jornada Mista

- 44 horas semanais para a jornada diurna

- 36 horas semanais para a jornada noturna

Remuneração

- Tempo extra: $25 \%$ (dia) e $50 \%$ (noite)

- Recargo de $75 \%$ para trabalho extra jornada noturna

- Descansos e feriados

- Um dia de descanso a cada seis dias de trabalho (Domingo)

- Feriados remunerados: $1^{\circ}$ de janeiro, 14 de abril, $1^{\circ}$ de maio, 15 de setembro,

3, 12, e 21 de outubro, 25 de dezembro e Páscoa (Quinta e Sexta feiras, Sábado)

Férias

- 1 ano $=10$ dias

- 2 anos $=12$ dias

- 3 anos $=15$ dias

- $\quad$ mais de três anos $=20$ dias

Regulamentação Salarial

- Mínimo elou por peça trabalhada (Não menos que o salário mínimo)

\section{Seguridade Social}

- Cobre doença, acidentes, invalidez, velhice e morte

- O empresário paga 7\% e o empregado 3,5\%, baseado no salário mínimo de Lps. 2400,00

Fonte: Catalago de promoção da Fundación para LA Inbversion y Desarrollo de lãs Exportaciones - FIDE, 2002 
A atividade comercial relacionada com a maquila tem se incrementado nos últimos anos e inclui: comércio de maquinaria e equipamento, peças de reposição e acessórios, assim como a exportação de produtos de segunda qualidade ou com defeitos. Estas empresas maquiladoras representam $11.3 \%$ do total. Da mesma forma, se incrementaram as atividades de serviços como: estoque, lavanderias, passadorias, tinturarias, manutenção e reparo de equipamento e maquinaria. Estas empresas têm uma participação de 6,6\%, como apresenta a tabela 2.20 .

Pequenos empresários entrevistados afirmaram comprar eventualmente retalhos ou peças de tecido que sobram da maquila. Assim mesmo, existe um mercado de máquinas de segunda e mesmo novas importadas, ao qual o empresário local que produz para o mercado interno tem acesso.

Tabela 2.20 -

Setores predominantes nas ZIP e ZOLI (2000)

\begin{tabular}{|l|c|c|}
\hline Setores & Número de empresas & \% \\
\hline Têxtil- vestuário $^{\text {a }}$ & 145 & 68,4 \\
\hline Indústrias várias $^{b}$ & 29 & 13,7 \\
\hline Comércio $^{\text {c }}$ & 24 & 11,3 \\
\hline Serviços $^{\text {a }}$ & 14 & 6,6 \\
\hline Total & 212 & 100 \\
\hline
\end{tabular}

${ }^{a}$ Camisas de malha, roupa íntima masculina e feminina, roupa desportiva, Blusas (sweaters), abrigos e roupa infantil e para adultos (camisas e calças compridas); as que incluem prendas de marca de grandes firmas, o principal destino é o mercado dos Estados Unidos.

b "Palilleras" (produtoras de cabos e palitos de madeira), móveis para o lar (madeira, vime e metal), vassouras e limpadores de chão, mochilas, autopeças, purê de frutas, medicamentos e químicos, bolas de soft-ball e baseball.

c Comércio de maquinaria e equipamento, pecas de reposição e acessórios, assim como a exportação de produtos de Segunda Qualidade ou com defeitos.

d Serviços de estoque, lavanderias, passadorias, tinturarias, manutenção e reparo de equipamento e maquinaria.

O mercado interno hondurenho também é extremamente competitivo e pulverizado. As empresas locais concorrem pelos poucos espaços que restam do mercado interno. As pequenas redes locais de roupas populares e redes especializadas de "boutiques" ou "ateliês" produzem moda feminina para os setores da classe média alta, assinados por designers locais. Algumas delas subcontratam a produção inclusive em oficinas 
familiares, outras produzem elas próprias. As empresas nacionais competem com os estabelecimentos que vendem marcas internacionais. As redes de varejo estrangeiras se instalam e importam muitos produtos padrão através do Panamá.

As pequenas e médias empresas que produzem para o mercado local sofreram uma grande informalização, com menores ou nenhum incentivo ou isenções e um mercado com baixo poder aquisitivo que utiliza também a subcontratação e o trabalho informal e precário.

Há uma grande diferença entre as maquilas de exportação e aquelas empresas também assim autodenominadas que atuam para o mercado local, que vai desde o equipamento utilizado, os métodos de organização da produção, os salários pagos e as condições de trabalho. As maquilas vinculadas ao mercado internacional, que produzem roupas de marcas famosas, são como seus clientes: muito sensíveis às pressões do consumidor e da mídia internacional. Por isso realiza esforços para a obtenção de melhorias nas condições de trabalho, inclusive procurando diminuir a rotatividade da MDO $e$ valorizando a experiência, na tentativa de elevar os padrões de qualidade $e$ produtividade.

Enquanto a pesquisa de CEPAL (1998) mostrou que a maioria das plantas maquiladoras de roupa da América Central não realizam atividades de $P \& D$, três grandes corporações hondurenhas tinham seus próprios departamentos de pesquisa orientados à melhoria da produtividade, adaptação de processos e criação de acessórios para a melhor operação das máquinas, que se realizam por causa de uma retroalimentação entre os engenheiros hondurenhos e os seus colegas estadunidenses.

É de design onde os serviços educativos são mais carentes. Por isso, uma das empresas pesquisadas está procurando subcontratar no exterior a capacidade de design para poder oferecer a seus clientes serviços completos de full-package, enquanto prepara sua própria capacidade interna. 
Já na capacitação da força de trabalho, o "Instituto Nacional de Formación Profesional" - INFOP, que recebe financiamento da empresa privada, tem participado da capacitação da MDO, mas muitas das empresas preferem capacitar seu pessoal dentro da mesma firma e implementaram escolinhas próprias para o treinamento nas suas instalações.

A AHMA, o INFOP e a Cooperação Técnica de Taiwan trabalham para a instalação de um Centro de Capacitação Tecnológica para a Indústria Têxtil.

Em relação às capacidades de engenharia e gestão, foi apontado por um consultor estrangeiro da área de Recursos Humanos, entrevistado na pesquisa da tese, que num dos maiores grupos, para a sua admiração, encontrou alto percentual de engenheiros com pós-graduação em universidades estrangeiras de primeira linha, este percentual seria mais alto do que em outros países da região.

Não obtive dados concretos, mas cabe mencionar que a oferta de cursos de graduação em engenharia industrial, por exemplo, cresceu muito no país a partir da década de 1980, em função da demanda de recursos humanos capacitados para o processo de retomada da industrialização. Estes cursos são quase sempre oferecidos nas novas universidades privadas estabelecidas nas últimas décadas, o que coincide com o período de desenvolvimento da maquila. Elas vieram suprir as necessidades que a universidade pública, sozinha, não supria. O nível da matrícula universitária passou de 6,6\%, em 1995, para 7,45, em 2000 (FIDE, 2002).

Em nível externo, a maior barreira para o desenvolvimento da IHMR são as restrições comerciais, e no âmbito interno é a falta de recursos financeiros para investimento local. O crédito é um dos limitantes do empresariado local, que, quando possível, prefere conseguir dinheiro no exterior. 


\subsubsection{Problemática da Progressão Industrial na Indústria Hondurenha de Maquila de Roupas - IHMR}

Refletindo sobre este panorama podemos inferir que há indícios de uma Progressão Industrial nas duas décadas da moderna maquila hondurenha. Na questão dos processos executados pelas maquiladoras e nos produtos finais de que são capazes de oferecer como pacotes completos, diferente da única operação de costura realizada no início da Indústria Hondurenha de Maquila de Roupas - IHMR.

A tímida diversificação de produtos como a confecção de jaquetas, sobretudos e vestidos, que requerem um pouco mais de habilidade do que as camisetas de malha e outros produtos básicos, bem como os investimentos em atividades de suporte como tinturaria e estamparia, mostram uma leve integração de atividades, ambos os casos são exemplos de uma Progressão Industrial, em processos e em produtos. De qualquer forma, se aprecia uma diversificação industrial e uma complementação de atividades e funções na CPTV, na direção de uma Progressão funcional.

A demanda por engenheiros industriais e outros universitários é uma das claras e mais vantajosas interações com o ambiente local.

Deve-se analisar mais detalhadamente estes indícios, e tentar avaliar a real magnitude de um processo de Progressão Industrial nas maquilas hondurenhas. E se este segue os padrões do modelos teóricos. 


\subsection{As cadeias de produção têxtil-vestuário brasileiras}

Algumas das empresas que hoje são líderes foram constituídas pelas famílias tradiciona is brasileiras para suprir as necessidades da população e da indústria locais. Não obstante, foi somente com a chegada dos imigrantes europeus, ao final da Segunda Guerra Mundial (Scherer, 1994), que veio a se consolidar a indústria de vestuário. Em sua maioria se dedicaram, no começo, a comercializar tecidos e depois à fabricação de roupas masculinas.

A introdução de fibras químicas e de fabricação de tecidos modernos impulsionou o setor, transformando a fabricação e a comercialização de roupas, que deixaram de ser feitas sob medida, para serem produzidas em série e comercializadas prontas no comércio varejista.

Com o tempo, alguns aglomerados locais ou regionais de empresas, formados espontaneamente, se consolidaram como pólos de produção têxtil e de vestuário em torno dos principais centros urbanos. No estado de São Paulo, a região de Americana constituiu-se no maior pólo têxtil do Brasil e ali também se instalaram pequenas confecções.

Nos centros do Rio de Janeiro e São Paulo se instalaram fábricas de roupas que depois foram transferidas para a periferia. Atualmente, nestas duas cidades se localizam ainda os centros diretores de toda a cadeia produtiva, executando atividades desde desenho até o marketing, controlando o fluxo de insumos e matérias primas e a distribuição de produtos acabados.

Posteriormente deu-se o ingresso das empresas estrangeiras com estratégias multi domésticas, instalando plantas produtoras subsidiárias e escritórios ou licenciando seus 
produtos no mercado brasileiro. Alguns produtos como o denim e as calças jeans foram produtos exportados daqui, ocupando o Brasil posições de liderança nesses produtos.

Após a abertura do mercado, em 1990, a indústria brasileira está passando por um radical processo de reestruturação. No setor têxtil-vestuário tal abertura teve como conseqüência a invasão de produtos de origem asiática a preços baixíssimos, conseguindo impactar fortemente a indústria nacional.

Como resposta a esses desafios, as empresas brasileiras adotaram estratégias de redução de custos, por meio, principalmente, da desverticalização crescente de seus processos, recorrendo a práticas de subcontratação produtiva. Verificou-se também um movimento de relocalização dos elos produtivos da cadeia, deslocando-se dos tradicionais centros produtores do Sul e Sudeste em direção a regiões que apresentam custos, principalmente de trabalho, mais reduzidos, o que fez com que muitas empresas estabelecessem unidades produtivas principalmente na Região Nordeste do Brasil, por causa dos incentivos oferecidos por estados dessa região.

Esta reação, assim como investimentos elevados na modernização do equipamento e estratégias de gestão empresarial com metas e objetivos mais integrados, visando a eficiência coletiva ao longo da cadeia produtiva, tem como resultado uma notória recuperação da indústria fundamentada na inovação, no design e nas tecnologias de gestão e de Tecnologia da Informação - TI. 


\subsubsection{Processo de formação da indústria do vestuário no Brasil}

O desenvolvimento da indústria têxtil no Brasil passa por várias etapas desde a segunda metade do século XIX, com as quais contribuiriam alguns fatores como o crescimento da produção de algodão, estimulado pela demanda crescente de vestuário, de sacaria para o café, açúcar, cereais etc., e a mão de obra escrava ${ }^{29}$ que barateava a produção (Tessari, 1999).

Foi somente um século depois da Revolução Industrial (1760-1830), a da mecanização dos teares, que os primeiros investimentos na indústria têxtil aconteceram no país (Goularti et Neto, 1997). A pesar disso, o "complexo têxtil-vestuário-calçados” (Ferraz ${ }^{30}$, 1996) destacou-se, dentre outros, no processo de industrialização do Brasil.

A Bahia foi o principal centro da indústria do algodão até a década de 1860, concentrando nela e nos seus arredores cinco das nove fábricas do país. Já em 1885 a maioria (69\%) das fábricas têxteis localizavam-se nos estados do Rio de Janeiro, São Paulo e Minas Gerais. Em 1870, a cidade do Rio de Janeiro substituía a Bahia como centro da indústria, e em 1915 haviam 202 fábricas disseminadas por 17 estados, nas quais trabalhavam 82.247 operários (Tessari, 1999).

A guerra civil estadunidense (1860) representou um novo incentivo para a indústria brasileira têxtil do algodão, que expandiu sua área cultivada para substituir as importações.

\footnotetext{
${ }^{29}$ Para proteger as indústrias portuguesas e evitar a utilização da MDO escrava em outros trabalhos que não a agricultura, a coroa Portuguesa proibiu as indústrias de transformação na colônia, excetuando a manufatura de tecidos grosseiros de algodão para vestir os escravos e os pobres. A proibição só foi suspensa em 1808, quando a coroa mudou-se para o Brasil.

${ }^{30}$ Complexo têxtil-vestuário -calçados; conceito usado por Ferraz (1996) e outros autores para agrupar e relacionar estas três tradicionais indústrias.
} 
Algumas das empresas que hoje são líderes, como a Hering, fundada em 1880, foram constituídas familiarmente, e de forma geral dedicaram-se primeiro ao comércio de tecidos e depois à fabricação de roupas masculinas, para a satisfação das demandas locais.

Na década de 1920 os maiores setores industriais, pelo número de estabelecimentos e pela quantidade de pessoal ocupado eram o alimentício e o têxtil, em terceiro lugar estava a indústria do vestuário, que representava 14,9\% das empresas e 10,7\% do emprego industrial.

O censo de 1940 mostra a progressiva diversificação industrial do país, na qual a indústria da confecção aumenta sua participação, mas ainda até a década de 1970 a participação da indústria têxtil era maior em valor de transformação industrial e de pessoal empregado (IBGE, 1995, apud Kontic, 2002).

Essa década foi marcada por um estancamento da indústria têxtil, que acabou no período de 1967 a 1974, com o chamado "Programa de Sucateamento Compensatório", que teve seu primeiro estágio de automação.

Com as restrições à importação de maquinarias desde 1979 e a proteção do mercado, entre 1974 e 1989, a indústria se acomodou e teve dificuldades para acompanhar a competição e modernização que acontecia mundo afora.

No segmento da fiação, a consolidação da produção de fibras químicas ${ }^{31}$, no início da década de 1960, possibilitou a fabricação de tecidos modernos que impulsionaram o setor, transformando em conseqüência a fabricação e a comercialização de roupas, que passaram a ser comercia lizadas prontas no comércio varejista.

\footnotetext{
${ }^{31}$ A produção de fibras artificiais iniciou-se no Brasil em 1931, pela Rhodia S.A. Mas o grande salto na capacidade de produção instalada só ocorreu nos anos 60 e início dos 70. De 1960 a 1973, esta capacidade foi a 194\% (Macarini et Biasoto, 1985, in Branski, 1990, apud Goularti et Neto, 1997).
} 
A região de Americana, no estado de São Paulo, constituiu-se no maior pólo têxtil do Brasil na área dos tecidos sintéticos, onde também se instalaram pequenas confecções.

Em todo o país desenvolveram-se centros regionais: Santa Cruz de Capibaribe, no Nordeste, destacando-se primeiro pela produção de fios de algodão, de tecidos artesanais, confecção de artigos de vestuário simples e principalmente lingerie produzida com retalhos industriais procedentes de São Paulo.

No Sul, destacaram-se Blumenau e algumas cidades do norte do estado de Paraná e do Sul de Santa Catarina, nesta região desenvolveram-se malharias e confecções cujos produtos finais são diversos, desde camisetas até ternos (Goularti et Neto, 1997). Uma das empresas ícones da indústria nacional é a Hering, que ao longo de sua história tem passado por muitas transformações.

No Rio Grande do Sul, a empresa Renner foi, junto a Varig (aviação), um dos pilares do desenvolvimento da cidade de Porto Alegre (Fortes, 2001) na década de 1930.

Ainda nos anos 1960, aconteceu um outro momento importante do processo de industrialização brasileira: a implantação do Pólo Industrial de Manaus, baseado em incentivos fiscais, sendo que $80 \%$ de sua produção era "exportada" para o resto do Brasil. Inicialmente constituído por 11 diferentes indústrias, entre elas a têxtil, contudo, a indústria de componentes eletrônicos era responsável por $60 \%$ do parque industrial. Desde 1985 a indústria de motocicletas tem crescido, enquanto a têxtil vem declinando (Fleury et Fleury, 1998).

Nas regiões centrais de cidades como Rio de Janeiro e São Paulo instalaram-se fábricas de roupas, no caso de São Paulo grande parte do comércio atacadista ainda encontrase nos mesmos bairros, enquanto que na maioria das cidades as atividades produtivas foram paulatinamente deslocadas para os subúrbios. 
A indústria do vestuário de São Paulo passou por vários momentos. No começo do século XX chegaram os sírios e os libaneses especializados no comércio de tecidos, roupas e armarinhos, instalaram suas lojas sobretudo na região central da cidade - na famosa rua 25 de Março e no bairro do Brás. Mais tarde, envolveram-se também na produção de tecidos.

Com a chegada dos imigrantes europeus, ao final da Segunda Guerra Mundial (Scherer, 1994), a indústria do vestuário começou a se consolidar. Uma nova leva de “árabes” se estabeleceu na cidade e, com o apoio de seus patrícios, desenvolveram a produção de roupas íntimas e outros produtos básicos.

Os judeus e os italianos, muitos dos quais se especializaram na alfaiataria $e$ desenvolveram produtos mais elaborados, sobretudo de moda feminina, estabeleceramse no Brás. Até a década de 1950 a indústria do vestuário em São Paulo produzia basicamente roupas brancas (Kontic, 2002). Pequenas oficinas semi-artesanais de moda feminina satisfaziam as necessidades locais, ou, mais comumente, as pessoas compravam os tecidos e as roupas eram feitas em casa, por costureiras ou alfaiates autônomas (os).

Os também migrantes brasileiros nordestinos desenvolveram trajetórias surpreendentes, de acordo com Kontic (2002), passando de representantes comerciais a produtores de produtos mais baratos em grande escala. Estabelecendo-se também no Brás, beneficiaram-se do parque industrial existente, do conhecimento do gosto local, além de usarem as políticas de crédito baseadas na confiança aos clientes que outros grupos paulistas e catarinenses não ousariam. Com o crescimento do comércio atacadista foram deslocando suas oficinas para a Zona Leste e Gua rulhos, na Grande São Paulo.

De acordo com Kontic (2002), a indústria brasileira de vestuário se estruturou e expandiu durante os anos 60, graças a popularização de dois ícones do processo de urbanização e de formação de mercados de massa mundiais: a calça jeans e a camiseta 
de algodão, por meio dos quais a linha de produção em série do Modelo Fordista foi introduzida na indústria do vestuário brasileira.

Já na década de 1990, foram os coreanos os responsáveis pela renovação da indústria local. Os primeiros chegaram na década de 1970 e se estabeleceram como atacadistas e produtores de artigos populares, similares aos produzidos anteriormente pelos nordestinos. Nos anos de 1980, evoluíram para a confecção de artigos de "modinha", inovando na resposta rápida e capitalizando o desenvolvimento tecnológico dos produtores têxteis e de maquinaria coreanos, de quem se tornaram clientes e distribuidores.

A partir da década de 1970 empresas estrangeiras, que inicialmente utilizaram estratégias multi domésticas, instalaram plantas produtoras subsidiárias e escritórios ou licenciaram seus produtos no mercado brasileiro. Entre as pioneiras está a Levi's, que chegou ao Brasil em 1972. Assim como ela, outras empresas estrangeiras chegaram e, com freqüência, licenciaram marcas para produtores nacionais, o que ajudou o desenvolvimento da produção em escala. Rapidamente o Brasil tornou-se um exportador de tecidos denim e também de jeans.

\subsubsection{A década de 1990 e a abertura de mercado}

Depois da abertura do mercado, em 1990, a indústria brasileira está passando por um radical processo de reestruturação. De um lado, este processo é fortemente influenciado pela mudança de estratégias e padrões de gerência das corporações transnacionais. Por outro lado, depende também da capacidade das empresas locais em termos de criação de competências obrigatórias para a participação efetiva junto às novas formas de organização coletiva - cadeias, redes, clusters - que são características da nova economia (Fleury, 1999). 
No complexo têxtil-vestuário, a abertura do mercado teve como consequiência inicial a invasão de produtos de origem asiática a preços baixíssimos - com freqüência diz-se que de pouca qualidade-, conseguindo impactar fortemente a indústria nacional.

Os efeitos da abertura comercial foram diversos durante a década de 90 na indústria têxtil: tanto o número de empresas quanto a oferta de emprego caíram sensivelmente. Já o desempenho da indústria de confecções foi um pouco melhor: o número de estabelecimentos aumentou quase 20\% de 1993 a 1995. Apesar do volume de produção aumentar em 26\%, o seu valor diminuiu (Carvalho et Serra, 1998 a) sensivelmente.

Como resposta a esses desafios, as empresas brasileiras adotaram estratégias de redução de custos, por meio principalmente da desverticalização crescente de seus processos, recorrendo a práticas de subcontratação ${ }^{32}$ produtiva, as quais podem ser classificadas como facção industrial ou domiciliar (Goularti et Neto, 1997). A subcontratação industrial é uma prática anterior à reestruturação produtiva dos anos 90, porém, a partir de então, ao mesmo tempo em que se difunde mais, torna-se mais precarizante.

Assim como no contexto internacional, neste processo de reestruturação os estados brasileiros concorrem entre si para hospedar as novas plantas de produção. Algumas das variáveis nesta concorrência são a abundante MDO de baixo custo, incentivos

\footnotetext{
${ }^{32}$ Esta subcontratação pode ser de economia, especialização ou capacidade (Souza, 1990 apud Goularti et Neto, 1997) de economia quando o objetivo maior é a redução de custos para a contratante, de especialização, quando a empresa contratante busca especialistas com conhecimentos, equipamentos ou outra vantagem técnica que ela não possua, e é de capacidade quando a empresa contratante, possuindo a capacidade tecnológica e de escala, eventualmente necessite complementar a sua produção para atingir a demanda.
}

Um exemplo interessante de relocalização e reestruturação é a empresa Hawaian Dreams, dona de uma das duas maiores marcas de surfwear brasileira. A HD é parceira de uma das maiores marcas mundiais para quem produz e distribui linhas para o mercado brasileiro. Esta empresa paulistana, por causa dos custos de produção e conflitos com os sindicatos, convidou suas fornecedoras a mudarem-se para Minas Gerais, organizando um consórcio modular inspirado na indústria automobilística. A empresa é detentora de uma marca nacional e licenciada de outra estrangeira no setor de surfwear, e dona de quase metade do mercado nacional. Todo o processo produtivo se realiza nas mesmas instalações. Empresas terceirizadas executam a costura, serigrafia, tingimento e bordado. Ela própria executa o fornecimento de materiais (muitos dos quais são importados), corte de tecidos, acabamento e embalagem para ter maior controle de qualidade; design, marketing e distribuição são realizados em São Paulo (Entrevis ta realizada em 1999). 
fiscais, localização geográfica, facilidades de crédito, de infra-estrutura e investimento dos governos, interessados em gerar emprego e renda em suas regiões.

Houve também um movimento de relocalização dos elos produtivos da cadeia, deslocando-se dos tradicionais centros produtores do Sul e Sudeste em direção a regiões que apresentassem custos, principalmente de trabalho, mais reduzidos, o que fez com que muitas empresas estabelecessem unidades produtivas principalmente na Região Nordeste do Brasil, por causa dos incentivos oferecidos por estados desta região.

Em 1995, a região sudeste respondia sozinha por $65 \%$ da produção física e abrigava $64 \%$ de todos os estabelecimentos do país. Nesse período houve um crescimento significativo em outras regiões, como a região norte, com um aumento de $49 \%$ da produção, entre 1993 a 1995, enquanto a região sul apresentou um decréscimo de produção de $28 \%$ (Carvalho et Serra, 1998).

São Paulo perdeu importância relativa na produção de artigos padronizados, abrigando somente 39\% das empresas nessa época, que se trasladam para o Nordeste e Minas Gerais. Já a indústria da moda prefere subcontratar as facções no sul catarinense e no norte paranaense, em Minas Gerais e Rio de Janeiro, pelas possibilidades de resposta rápida necessária para satisfazer as cambiantes demandas da indústria do vestuário de moda, cujo desenvolvimento e consumo são maiores nos grandes centros urbanos.

De acordo com Bastos (1993), a sub-contratação tornou-se um mecanismo que visa contornar as obrigações tributárias e trabalhistas. Na realidade, com a desculpa da flexibilidade e do foco nas core competences, as empresas buscam baixar custos pela redução de encargos sociais, o que leva a uma informalização e precarização das relações de produção das empresas entre si e entre estas e os trabalhadores. 
Neste processo de informalização do trabalho, tanto a facção domiciliar quanto a industrial contribuem para a precarização do trabalho. No trabalho a domicílio, o esvaziamento de pólos industriais e o surgimento de outros no Norte de Santa Catarina e no Sul paranaense são relatados por Goularti et Neto (1997), no qual pequenas empresas familiares são constituídas como faccionistas domiciliares.

Este processo estende-se pelo país inteiro. Lima $(1998,2002)$ relata a experiência em diversos estados do nordeste brasileiro onde o Estado, organizações do terceiro setor e empresas privadas locais, nacionais e internacionais, estabeleceram estratégias de industrialização e geração de emprego pouco qualificado, pouco remunerado e com pouco investimento para sua geração, em regiões pobres nas quais nunca houve emprego formal anteriormente. Para isto promoveram e organizaram cooperativas de produção e de trabalho, em que a vantagem seria a redução de custos de produção em torno de $50 \%$ no pagamento de salários, e por não ter que arcar com o ônus pela gestão direta e custos presentes no contrato de trabalho, e ainda distantes das pressões dos sindicatos existentes nas capitais.

No estado do Ceará, pioneiro e modelo para os outros estados nordestinos neste modelo de industrialização e geração de renda, merece destaque o caso do Pólo Confeccionista do Baturité, iniciado em 1991 no município de Acarape (50 Km de Fortaleza) por um grupo investidor taiwanês. O projeto previa exportação para o mercado americano, constituído por cinco unidades fabris: uma de máquinas de costura, uma montadora de motores para máquinas de costura, uma fábrica de confecções, uma montadora de jipes utilitários de fibra de vidro e uma fábrica de gelatina comestivel. A fábrica de confecções mantinha sua produção totalmente terceirizada em cooperativas de produção dos arredores, somente os técnicos e supervisores eram funcionários da empresa.

O projeto não teve os resultados esperados para nenhuma das partes, foi abandonado na maioria dos 15 municípios alegando super-dimensionamento e alto custo da logística. As 
trabalhadoras entraram na justiça para haver e rever seus direitos e as promessas não cumpridas. As poucas unidades restantes da empresa dirigiram sua produção para o mercado nacional.

No estado de São Paulo, as empresas que não conseguiram transferir sua produção para locais de produção mais baratos fora do estado, buscam formas alternativas para baixar os custos de produção, sendo uma delas a subcontratação em cooperativas. Estas cooperativas podem ser formadas por ex-empregados de indústrias ou mesmo exempregados da própria empresa. Na organização das cooperativas de costureiras, também participam entidades sindicais, como a CUT, os governos municipais e estaduais, organizações de capacitação técnica especializadas, ONGs, e universidades, por meio das Incubadoras Tecnológicas de Cooperativas Populares - ITCP (CruzMoreira, 2001).

No setor têxtil algumas empresas falidas foram tomadas pelos trabalhadores em negociação com os donos ou por autorização da justiça para operá-las ou arrendá-las em troca das dívidas dos direitos trabalhistas.

Com raras exceções, as cooperativas enfrentam os mesmos, ou até mesmo, mais obstáculos do que as micro e pequenas empresas para sua viabilidade e inserção no mercado formal, entre eles: a baixa escala de produção, também associada à falta de equipamento adequado, falta de acesso ao crédito e às altas taxas para a legalização e operação formal.

Para resumir a relocalização da CPTV, a tabela 2.21, a seguir, mostra percentualmente a evolução da participação das grandes regiões brasileiras na produção da cadeia têxtilvestuário de 1990 a 2000. 


\begin{tabular}{|l|c|c|c|c|c|c|c|c|c|}
\hline \multirow{2}{*}{$\begin{array}{l}\text { Elos da } \\
\text { Cadeia }\end{array}$} & \multicolumn{2}{|c|}{ Nordeste } & \multicolumn{2}{|c|}{ Sudeste } & \multicolumn{2}{c|}{ Sul } & \multicolumn{2}{c|}{$\begin{array}{c}\text { Norte e } \\
\text { Centro-Oeste }\end{array}$} & \multirow{2}{*}{ Total } \\
\cline { 2 - 9 } & 1990 & 2000 & 1990 & 2000 & 1990 & 2000 & 1990 & 2000 & \\
\hline Fios & 24,9 & 35,4 & 55,2 & 42,6 & 17,2 & 21,7 & 2,7 & 0,3 & 100 \\
\hline Tecidos & 17,6 & 21,5 & 65,6 & 62,0 & 12,8 & 13,7 & 4 & 2,8 & 100 \\
\hline Malhas & 2,8 & 10,0 & 39,9 & 35,2 & 55,7 & 53,5 & 1,6 & 1,3 & 100 \\
\hline Confecções & 8,0 & 11,3 & 66,6 & 56,1 & 21,6 & 25,4 & 3,8 & 7,2 & 100 \\
\hline Geral & \multicolumn{13}{|c|}{} & $\mathbf{1 3 , 3 , 3}$ & $\mathbf{5 6 , 8}$ & $\mathbf{4 9 , 0}$ & $\mathbf{2 6 , 8}$ & $\mathbf{2 8 , 5}$ & $\mathbf{3 , 1}$ & $\mathbf{2 , 9}$ & $\mathbf{1 0 0}$ \\
\hline
\end{tabular}

Fonte: Adaptado de: IEMI, 2001, pag.54 In Prochnik 2002.

Prochnik et Une (2001) ressaltam algumas implicações importantes no crescimento da participação da Região Nordeste como:

- A compensação entre baixa produtividade (por falta de capacitação) com os baixos salários, aponta a melhoria e o engajamento do trabalhador nordestino para o aumento da eficiência.

- A dispersão geográfica dos investimentos devido à ampla oferta de incentivos em quase todos os municípios e regiões remotas, sem infra-estrutura apropriada, o que dificulta a formação de clusters e a construção de suas economias de escala e demais vantagens.

- Os investimentos mais bem sucedidos são daquelas empresas maiores, caracterizados, que já têm estruturadas as suas cadeias de fornecimento, logística e de clientes. Geralmente essas cadeias são lideradas pelas matrizes fora da região de forma vertical, com relações intrafirma ou com antigos parceiros, o que dificulta a disseminação de conhecimento e tecnologia, assim como a estruturação de vínculos com empresas e economia locais. 
Considerando que a maioria da produção nordestina é de produtos básicos de algodão, há que se apontar a necessidade de investimentos em logística, já que o crescimento da produção de fios e tecidos acontece no nordeste, enquanto que o novo pólo de produção do algodão esta se desenvolvendo no centro-oeste.

A reestruturação também teve pontos positivos para a competitividade geral da indústria nacional, significou um ciclo de fortes investimentos em vários segmentos da cadeia têxtil-vestuário, a modernização fez cair de 6,46 para 5,73 anos a idade média do maquinário em 1999 (ABRAVEST, 2000) ${ }^{33}$. A tabela 2.22 mostra os valores investidos na modernização do maquinário, realizado entre 93 e 97, com o seu auge em 1995.

Tabela 2.22 - Produção e importação de máquinas têxteis no Brasil (milhões de dólares)

\begin{tabular}{|c|c|c|c|}
\hline Ano & $\begin{array}{c}\text { Produção Nac. de } \\
\text { Máquinas Têxteis }\end{array}$ & $\begin{array}{c}\text { Importação de Máquinas } \\
\text { Têxteis }\end{array}$ & Total \\
\hline 1990 & 307 & 377 & 684 \\
\hline 1991 & 234 & 342 & 576 \\
\hline 1992 & 217 & 251 & 468 \\
\hline 1993 & 275 & 337 & 612 \\
\hline 1994 & 314 & 611 & 925 \\
\hline 1995 & 316 & 738 & 782 \\
\hline 1996 & 262 & 520 & 808 \\
\hline 1997 & 221 & 587 & 682 \\
\hline 1998 & 214 & 468 & 558 \\
\hline 1999 & 185 & 373 & 658 \\
\hline 2000 & 185 & 453 & \\
\hline
\end{tabular}

Fonte : SECEX/ABIMAQ/IEMI in Prochnik 2002.

Além da modernização do maquinário e da relocalização para locais de mais baixo custo, a reestruturação também significou a concentração dos negócios e da gestão das cadeias.

São Paulo se consolida como centro intelectual e financeiro das cadeias têxtil-vestuário brasileiras, funciona como centro de comercialização e de distribuição de

\footnotetext{
33 (http://www.abravest.org.br/abravest/projetos.htm, 05/set/2000).
} 
matérias primas e produtos acabados, o que permite a empresas ali sediadas controle de atividades produtivas distantes, além do design, marketing, e dos investimentos nos negócios da moda.

Na promoção e no marketing dos negócios da moda, o evento intitulado "São Paulo Fashion Week - SPFW", que reúne os maiores criadores do país, mobiliza empresas de todos os elos da cadeia produtiva desde os fornecedores de fibras até os grandes varejistas, seja como criadores ou lançadores de produtos em parcerias com os designers ou nomes de marcas, bem como patrocinadores. O investimento em marketing internacional tem como resultado, entre outros, a cobertura do evento feita pela mídia especializada internacional.

Nessa onda, o Rio de Janeiro experimenta uma recuperação tanto em marcas quanto em eventos de promoção. Fortaleza vem se firmando como centro de moda no nordeste, seguida por Recife. Belo Horizonte e Porto Alegre são cidades que também têm sediado eventos que representam suas indústrias e produtos locais.

\subsubsection{A participação da cadeia têxtil-vestuário na indústria nacional brasileira}

Além da importância histórica no processo de industrialização brasileiro, as indústrias que compõem as cadeias de produção têxtil-vestuário, são importantes na conjuntura atual do país, entre outras razões, pela sua capacidade de geração de emprego para pessoas com pouca qualificação e com investimentos mínimos em capacitação.

Com 30.000 empresas, o setor emprega 1,4 milhão de pessoas e responde por 5\% do PIB. Desde 1994, recebeu investimentos no valor de 8 bilhões de dólares. Outros 12 bilhões devem ser absorvidos até 2008, segundo a Associação Brasileira da Indústria Têxtil e de Confecção - ABIT (2003). A estrutura recente do setor é mostrada na tabela 2.23 a seguir: 
Tabela $2.23-$

Estrutura empresarial da CPTV brasileira

\begin{tabular}{|l|r|r|r|}
\hline Segmento & Fibras/Filam & \multicolumn{3}{|c|}{ Têxteis } & Confecções \\
\hline \multicolumn{3}{|c|}{ Total por Segmento } \\
\hline Estabelecimentos & 25 & 3.305 & 18.797 \\
\hline Empregos (mil) & 15 & 339 & 1.233 \\
\hline Produção (mil ton./ano) & 640 & 1.750 & 1.287 \\
\hline Faturamento/ano (US\$ bi) & 1,4 & 16,6 & 27,2 \\
\hline \hline \multicolumn{7}{|c|}{ Médias por empresa } & 600 & 103 & 66 \\
\hline Empregados & 26 mil & 530 & 68 \\
\hline Produção ton/ano & 56 & 5 & 1,4 \\
\hline Fat. (US\$ milhões) & & & \\
\hline
\end{tabular}

Fonte: IEMI/ABRAFAS/AFIPOL, da tabela do IEMI (2001, pág. 26) apud Prochnik 2002.

Nota (1) apenas as indústrias químicas que fornecem fibras e filamentos para o elo têxtil.

A participação percentual da CPTV no valor agregado desta cadeia em relação a outras cadeias produtivas brasileiras decresceu, entre 1990 a 2000, de 3,2\% para 1,8\%, como mostrado na tabela 2.24 a seguir:

Tabela 2.24 - Participação percentual da CPTV e seus principais elos no total das cadeias produtivas brasileiras

\begin{tabular}{|c|c|c|c|}
\hline & & 1990 & 2000 \\
\hline \multirow{3}{*}{ Valor Agregado } & Toda a cadeia & $3,2 \%$ & $1,8 \%$ \\
\hline & Ind. Têxtil & $1,8 \%$ & $0,9 \%$ \\
\hline & In. Vestuário e Acessórios & $1,4 \%$ & $0,9 \%$ \\
\hline \multirow{3}{*}{ Pessoal Ocupado } & Toda a cadeia & $7,5 \%$ & $6,6 \%$ \\
\hline & Ind. Têxtil & $1,5 \%$ & $0,9 \%$ \\
\hline & In. Vestuário e Acessórios & $6,0 \%$ & $5,7 \%$ \\
\hline
\end{tabular}

Fonte: IBQP-PR In Prochnik 2002.

De acordo com os dados do Instituto de Estudos e de Marketing Industrial - IEMI (2001, In Prochnik 2002), a variação percentual da participação do segmento têxtil (neste caso incluindo fiação, tecelagem, malharias e beneficiamento), entre 1990 e 2000, foi de $62 \%$, e a das confecções, de $29 \%$ (incluindo vestuário com $31,25 \%$, meias e acessórios, linha lar e outros) para um total da cadeia de 40,7\%, mostrando uma queda maior no setor têxtil. 
O tamanho das empresas é diverso no Brasil, o que fica claro na tabela 2.25 a seguir:

Tabela 2.25 - Distribuição do número de estabelecimentos, número médio de empregados e remuneração média na cadeia têxtil/confecções brasileira em 2001

\begin{tabular}{|l|r|r|r|}
\hline $\begin{array}{l}\text { Faixa de número de } \\
\text { empregados }\end{array}$ & \multicolumn{1}{|c|}{$\begin{array}{c}\text { Número de } \\
\text { estabelecimentos }\end{array}$} & $\begin{array}{c}\text { Número Médio de } \\
\text { empregados }\end{array}$ & Remuneração Média \\
\hline Até 4 & 19.364 & 2,1 & 2,02 \\
\hline 5 a 9 & 8.128 & 13,6 & 2,14 \\
\hline 10 a 19 & 5.831 & 30,1 & 2,25 \\
\hline 20 a 49 & 4.172 & 68,8 & 2,39 \\
\hline 50 a 99 & 1.143 & 153,7 & 2,72 \\
\hline 100 a 249 & 624 & 349,5 & 3,38 \\
\hline 250 a 499 & 241 & 702,9 & 3,55 \\
\hline 500 a 999 & 85 & $1.673,3$ & 3,86 \\
\hline 1000 ou mais & 46 & $\mathbf{1 5 , 9}$ & 4,14 \\
\hline Total & $\mathbf{4 3 . 8 3 0}$ & $\mathbf{2 , 9 6}$ \\
\hline Fonte: Rais, 2001 $\ln$ Prochnik 2002 & & & \\
\hline
\end{tabular}

Como visto, é grande a heterogeneidade das empresas que compõem a CPTV brasileira, com predominância de microempresas e empresas de pequeno porte e média salarial total baixa.

\subsubsection{A participação dos têxteis e vestuário brasileiros no Mundo}

O principal destino das exportações brasileiras de vestuário é normalmente a Argentina, que em 1999 absorveu 30,41\% delas, equivalentes a US\$50,74 milhões e a 3.100 toneladas. O produto mais comprado são as roupas de malha (US\$ 32,31 milhões em 1999) seguidas pelos tecidos planos (US\$ 18,43 milhões em 1999) de acordo com a Análise Setorial da Gazeta Mercantil (Tessari, 2001).

Houve recuo das vendas para o MERCOSUL, América Latina e Ásia no último ano, as vendas cresceram para América do Norte (os três países do NAFTA) e para a União Européia, de acordo com a ABIT.

Na exportação para os Estados Unidos, havia quotas para 26 produtos da CPTV em 2001 e para 11 na União Européia - UE (Tessari, 2001). Em ambos os casos nenhuma das 
quotas foi atingida, para os Estados Unidos as que tiveram melhor desempenho em 1999 foram paletós e ternos, com 35\%, roupões com 34,9\% e camisas de malha masculinas e femininas com $27 \%$. Já no caso da UE os felpudos têm destaque, atingindo 50,94\% da quota, seguido dos tecidos tintos, com 19,66\% e 13,09\% das roupas de mesa; no vestuário as $t$-shirts atingiram $8,9 \%$ e as calças, $2,2 \%$. Na exportação mundial, os números gerais são apresentados a seguir:

Em 2002, o setor exportou US\$ 506,9 milhões em confecções, US\$ 121,0 em outras manufaturas, US\$ 225,8 milhões em tecido (sendo US\$ 172,7 em tecidos de algodão), US\$ 164,5 milhões em fibras têxteis, US\$197,0 milhões em fios e US\$ 55,5 milhões em filamentos. Somados, um total de US\$1,1807 bilhão, com uma queda de 9,3\% referente a 2001, quando as exportações alcançaram 1,3 bilhões de dólares.

O déficit nas exportações da cadeia, que chegou em 2000 a US\$ 384 milhões, passou para um superávit de US\$ 73,4 milhões em 2001. Mesmo assim, em 2003, e apesar dessa recuperação, o Brasil ainda só fornece $0,7 \%$ do total das exportações de vestuário no comércio internacional (dados da ABIT apud Salomão, 2003).

A Tabela 2.26 mostra a evolução do comércio de têxteis e de vestuário brasileiro no mundo, na década de noventa:

Tabela 2.26 - Participação brasileira no mercado de têxteis e de confecções

\begin{tabular}{|c|c|c|c|c|c|c|c|c|c|c|c|c|}
\hline & \multicolumn{2}{|l|}{1995} & \multicolumn{2}{|l|}{1996} & \multicolumn{2}{|l|}{1997} & \multicolumn{2}{|l|}{1998} & \multicolumn{2}{|l|}{1999} & \multicolumn{2}{|l|}{2000} \\
\hline & US\$ bi. & $\%$ & US\$ bi. & $\%$ & US\$ bi. & $\%$ & US\$ bi. & $\%$ & US\$ bi. & $\%$ & US\$ bi. & $\%$ \\
\hline \multicolumn{13}{|c|}{ Mundo } \\
\hline Têxteis & & 100 & & 100 & & 100 & & 100 & & 100 & & 100 \\
\hline Confecções & & 100 & & 100 & & 100 & & 100 & & 100 & & 100 \\
\hline \multicolumn{13}{|c|}{ Brasil } \\
\hline Exp. Têxteis & 999 & 0,9 & 1.007 & 0,9 & 1.022 & 0,9 & 892 & 0,8 & 822 & 0,7 & 900 & 0,7 \\
\hline Imp. Têxteis & 1.362 & 1,2 & 1.110 & 1,0 & 1.201 & 1,0 & 1.065 & 1,0 & 898 & 0,8 & 1.112 & 0,9 \\
\hline Exp. Confecções & 298 & 0,2 & 248 & $\overline{0,2}$ & 211 & $\overline{0,2}$ & 185 & 0,1 & 173 & 0,1 & 282 & 0,2 \\
\hline Imp. Confecções & 372 & 0,3 & 371 & 0,3 & 451 & 0,3 & 369 & 0,3 & 206 & 0,1 & 185 & 0,1 \\
\hline
\end{tabular}


As vendas de artigos com marcas brasileiras ainda não são representativas em valores, mas seu aumento é indicativo do sucesso feito pelos designers e pelas marcas locais, o que ajuda a criar uma imagem no exterior. A estratégia, segundo o presidente da ABIT, é deixar o corpo a corpo com os produtores de tecidos asiáticos, e tentar vender as roupas prontas com maior valor agregado (Caixeta, 2002).

As tabelas apresentadas a seguir indicam com maior detalhe a evolução das importações e exportações dos diversos segmentos na ultima década, entre 1990 e 1998 (Tabela 2.27), e na continuação, estatísticas parciais do começo da década de 2000 (Tabelas 2.28 e 2.29), quando os efeitos da reestruturação começam a aparecer.

Tabela 2.27 - Importações e exportações do têxtil-vestuário brasileiro

\begin{tabular}{|c|c|c|c|c|c|c|c|c|c|}
\hline \multirow[t]{2}{*}{ Setores } & \multicolumn{3}{|c|}{ Importações(US\$ mil) } & \multicolumn{3}{|c|}{ Exportações(US\$ mil) } & \multicolumn{3}{|l|}{ Balanço } \\
\hline & 1990 & 1998 & $\begin{array}{c}\text { Var. } \\
\%\end{array}$ & 1990 & 1998 & $\begin{array}{c}\text { Var. } \\
\%\end{array}$ & 1990 & 1998 & $\begin{array}{c}\text { Var. } \\
\%\end{array}$ \\
\hline Fibra /Fila. & 261.008 & 910.169 & 249 & 316.926 & 131.075 & -59 & 55.918 & -779.094 & $-1.493,3$ \\
\hline Fios & 37.784 & 87.282 & 131 & 264.916 & 118.781 & -55 & 227.132 & 31.499 & $-86,1$ \\
\hline Têxteis & 103.273 & 516.126 & 339,8 & 255.506 & 427.131 & 67,2 & 152.233 & -88.995 & $-152,5$ \\
\hline Tecidos & 63.655 & 211.556 & 232 & 158.638 & 218.281 & 38 & 94.983 & 6.725 & $-92,9$ \\
\hline Malhas & 1.917 & 45.184 & 2.257 & 2.188 & 24.570 & 1.023 & 271 & -20.614 & $-7.706,6$ \\
\hline Outros & 37.701 & 259.386 & 588 & 94.680 & 184.280 & 95 & 56.979 & -75.106 & $-231,8$ \\
\hline Confeccionados & 55.463 & 383.100 & 591 & 431.710 & 435.676 & 1 & 376.247 & 52.576 & $-86,0$ \\
\hline Vestuário & 45.033 & 302.218 & 571 & 234.763 & 178.199 & -24 & 189.730 & -124.019 & $-165,4$ \\
\hline 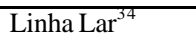 & 7.054 & 54.616 & 674 & 178.144 & 226.983 & 27 & 171.090 & 172.367 & $\mathbf{0 , 7}$ \\
\hline Outros & 3.776 & 26.266 & 678 & 18.803 & 30.494 & 62 & 15.027 & 4.228 & $-71,9$ \\
\hline Total & 457.528 & 1.896 .677 & 315 & 1.269 .058 & 1.112 .663 & -12 & 811.530 & -784.014 & $-196,6$ \\
\hline
\end{tabular}

\footnotetext{
${ }^{34}$ Linha Lar: Cama, mesa, banho e decoração.
} 
Apesar do aumento do volume comercializado, percebe-se acima que, no início da década, todos os balanços eram positivos e, no período, as variações das importações também foram positivas. No entanto, todas as exportações foram menores, algumas negativas, o que leva a uma variação geral negativa das exportações. As maiores variações, tanto em importações quanto em exportações, ocorreram no segmento malhas, sendo que as importações foram muito superiores.

Nas tabelas 2.28 e 2.29 nota-se que o valor das importações e das exportações caíram um pouco nos intervalos avaliados e, no geral, as importações caíram mais do que as exportações. A maioria dos preços também caiu, o que, no caso dos filamentos significou um aumento da quantidade importada. Somente o preço/Kg das linhas de costura importadas aumentou.

Já nas exportações também os preços caíram, exceto em outras manufaturas, que se mantiveram estáveis e nos filamentos, que aumentaram. Apesar do aumento, as exportações de filamentos tiveram o maior crescimento percentual no montante do faturamento (70\%), seguido dos fios e das linhas de costura, o restante teve variação negativa.

Os produtos mais valiosos das exportações e importações brasileiras são as confecções e as linhas de costura, apesar de que ambas tenham diminuído de preço, os produtos brasileiros exportados são mais caros do que os importados. Os preços dos tecidos vêm em terceiro lugar com preços similares aos dos produtos importados. $\mathrm{O}$ balanço total, que teve um aumento de $30 \%$, é detalhado na tabela 2.30 . 
Tabela $2.28-$

Importações da cadeia têxtil-vestuário brasileira (2001 e 2002)

\begin{tabular}{|c|c|c|c|c|c|c|c|c|c|}
\hline \multirow{2}{*}{$\begin{array}{l}\text { Produto } \\
\text { Importações }\end{array}$} & \multicolumn{3}{|c|}{$\begin{array}{r}\text { Jan-Out/2001 } \\
\end{array}$} & \multicolumn{3}{|c|}{\begin{tabular}{|c|} 
Jan-Out/2002 \\
\end{tabular}} & \multicolumn{3}{|c|}{\begin{tabular}{|c|} 
Variações \\
\end{tabular}} \\
\hline & \begin{tabular}{|c|} 
US\$ 1.000 \\
FOB \\
\end{tabular} & Toneladas & $\mathrm{US} \$ \mathbf{K g}$ & \begin{tabular}{|c|} 
US\$ 1.000 \\
FOB
\end{tabular} & Toneladas & US\$/Kg & $\begin{array}{c}\text { US\$ 1000 } \\
\text { FOB \% } \\
\end{array}$ & Ton. & $\mathrm{US} \$ / \mathbf{K g}$ \\
\hline Fios & $39.348,8$ & $12.051,7$ & 3,27 & $27.229,3$ & $11.473,4$ & 2,37 & $-30,8$ & $-4,8$ & $-27,5$ \\
\hline Filamentos & $283.817,4$ & $129.485,7$ & 2,19 & $253.458, \varnothing$ & $147.150,5$ & 1,72 & $-10,7$ & 13,6 & $-21,5$ \\
\hline Linhas de Costura & $1.518,5$ & 326,1 & 4,66 & $1.113,9$ & 238,7 & 4,67 & $-26,6$ & $-26,8$ & 0,2 \\
\hline Confecções & $154.762,5$ & $22.420,1$ & 6,9 & 109.516, & 18.222 & 6,01 & $-29,2$ & $-18,7$ & $-12,9$ \\
\hline $\begin{array}{l}\text { Outras } \\
\text { manufaturas }\end{array}$ & $187.313,4$ & $38.452,8$ & 4,87 & $162.114,6$ & $38.338,2$ & 4,23 & $-13,5$ & $-0,3$ & $-13,1$ \\
\hline
\end{tabular}

Fonte: Elaboração própria: dados da ABIT www.abit.org/dados de negócios em -/02/2003.

Tabela 2.29 -

Exportações da cadeia têxtil-vestuário brasileira (2001 e 2002)

\begin{tabular}{|c|c|c|c|c|c|c|c|c|c|}
\hline $\begin{array}{l}\text { Produto } \\
\text { Exportações }\end{array}$ & \multicolumn{3}{|c|}{ Jan-Out/2001 } & \multicolumn{3}{|c|}{ Jan-Out/2002 } & \multicolumn{3}{|c|}{ Variações \% } \\
\hline Fios & $101.204,5$ & $31.451,2$ & 3,22 & $107.101, \$$ & $43.418,5$ & 2,47 & 5,8 & 38,1 & $-23,3$ \\
\hline Tecidos & $271.082,2$ & $62.786,1$ & 4,32 & $225.826, \varnothing$ & $55.137,2$ & 4,1 & $-16,7$ & $-12,2$ & $-5,1$ \\
\hline Linhas de Costura & $4.664,8$ & 473,2 & 9,82 & $4.717,5$ & 563,6 & 8,37 & 1,1 & 19,1 & $-14,8$ \\
\hline Confecções & $536.032,3$ & $62.676,6$ & 8,55 & $506.890,1$ & $646.39,4$ & 7,84 & $-5,4$ & 3,1 & $-8,3$ \\
\hline $\begin{array}{l}\text { Outras } \\
\text { manufaturas }\end{array}$ & $145.539,6$ & $85.527,7$ & 1,70 & $120.926,8$ & 71.130 & 1,7 & $-16,9$ & $-16,8$ & 0,0 \\
\hline
\end{tabular}

Fonte: Elaboração própria: dados da ABIT www.abit.org/dados de negócios em -/02/2003. 
Tabela 2.30 -

Balança comercial na CPTV brasileira 2001-2002 (US\$1000 FOB)

\begin{tabular}{|c|c|c|c|c|c|c|c|}
\hline \multirow[b]{2}{*}{ Produto } & \multicolumn{2}{|c|}{ Jan-Out/2001 } & \multicolumn{2}{|c|}{ Jan-Out/2002 } & \multicolumn{3}{|c|}{ Balança } \\
\hline & Importações & Exportações & Importações & Exportações & $\begin{array}{c}2001 \\
\text { (Jan-Out) }\end{array}$ & $\begin{array}{c}2002 \\
\text { (Jan-Out) }\end{array}$ & $\underset{\%}{\operatorname{Var} .}$ \\
\hline Fibras Têxteis & 166234,1 & 209100,4 & $108.912,1$ & 164.486, & $42.866,3$ & $55.574,4$ & 29,6 \\
\hline Fios & 39348,8 & 101204,5 & $27.229,3$ & 107.101, & $618.55,7$ & $79.872,6$ & 29,1 \\
\hline Filamentos & $283.817,4$ & $38.493,3$ & $253.458,8$ & $65.536,7$ & -245.324 & -187.922 & 23,4 \\
\hline Tecidos & 244.175 & $271.082,2$ & $233.485,4$ & $225.826, \varnothing$ & $26.907,2$ & $-7.658,8$ & 128,5 \\
\hline Linhas de Costura & $1.518,5$ & $4.664,8$ & $1.113,9$ & $4.717,5$ & $3.146,3$ & $3.603,6$ & 14,5 \\
\hline Confecções & $154.762,5$ & $536.032,3$ & $109.516,6$ & $506.890,1$ & $381.269,8$ & $397.373,5$ & 4,2 \\
\hline $\begin{array}{l}\text { Outras } \\
\text { manufaturas }\end{array}$ & $187.313,4$ & $145.539,6$ & $162.114,6$ & $120.926,8$ & $-41.773,8$ & $-41.187,8$ & 1,4 \\
\hline Total & 1.077.170 & 1.306.117 & $\mathbf{8 9 5 . 8 3 0 , 7}$ & 1.195 .48 & $228.947,4$ & $299.655,4$ & 30,9 \\
\hline
\end{tabular}

Fonte: Elaboração própria: dados da ABIT www.abit.org/dados de negócios em 27/02/2003.

\subsubsection{Estrutura empresarial das cadeias têxtil-vestuário brasileiras}

Alguns estudos sobre a competitividade do setor utilizam as categorias "cadeias produtivas baseadas em fibras químicas" e "cadeias produtivas baseadas em fibras naturais”. Estas denominações refletem a forma tradicional ${ }^{35}$ de entender o setor, de acordo com estas análises, alguns setores têm potencialidades para a exportação.

\footnotetext{
${ }^{35}$ A classificação tradicional que divide as cadeias em "cadeias produtivas baseadas em fibras naturais" e "cadeias produtivas baseadas em fibras químicas" hoje é menos importante, pois o desenvolvimento de materiais e de produtos evoluiu e, a partir da fiação, são utilizadas misturas e acabamentos que conferem aos tecidos e aos produtos finais, caraterísticas similares de conforto e aparência. Muitos tecidos a base de fibras sintéticas com o adequado acabamento emulam as fibras naturais e as suas melhores características somadas a outras que agregam maior valor, conforto, durabilidade e aparência muito mais variadas do que anteriormente ou ainda facilidades para o seu uso e manutenção. No Brasil, as de maior relevância - o algodão entre as fibras naturais e o poliéster, a viscose e a poliamida entre as fibras químicas (Fleury, Fleury, Cruz-Moreira et al, 2001) - permitem diversas combinações entres si.
}

As empresas que lideram as cadeias produtivas, para atender essas demandas do mercado e para o processo criativo da moda, estão cada vez mais trabalhando com misturas de fibras naturais e manufaturadas. Isso implica em desafios sempre renovados para atingir padrões de qualidade e produtividade, especialmente nas atividades de acabamento que exigem novos conhecimentos e processos químicos específicos. 
Segundo o BNDES, existem segmentos com custos competitivos em nível internacional (Gorini, 1999), entre eles o de fiação. A tecelagem de tecidos planos (integrados) e o de malhas de algodão, conforme indica estudo do International Textile Manufacturers Federation - ITMF em 1995, utilizando o algodão como matéria-prima básica para comparação ${ }^{36}$.

Apesar do otimismo desta análise, é necessário lembrar que fios e tecidos são produtos intermediários, insumos ou matérias primas para produtos mais elaborados de vestuário e de outros confeccionados e, portanto, têm pouco valor agregado, como os produtos acabados como as roupas de malha e os produtos da linha lar. Estes produtos podem ser considerados como commodities ou pseudo-commodities e precisam de um eficiente e competitivo fornecimento de matérias primas básicas, as fibras têxteis.

A seguir apresenta-se uma síntese do panorama dos três grandes elos das cadeias produtivas têxtil-vestuário, produção de fibras e fiação, produção de tecidos e confecção, empresas comercializadoras (detentoras de marcas, atacadistas e varejistas). Para o primeiro elo unicamente, o de fornecedoras de fibras e empresas integradas à montante, utiliza-se a divisão entre fibras naturais e químicas.

\subsubsection{O elo das produtoras de fibras e as firmas integradas à montante}

Neste elo incluem-se as produtoras de algodão e de fibras químicas, assim como as empresas integradas à montante, algumas indo desde a produção de fibras ou fiação até a produção têxtil ou confecção.

\footnotetext{
${ }^{36}$ Entre os países selecionados nesse trabalho estão: a Itália, o Japão, a Coréia do Sul, a Índia e a Tailândia, nos três segmentos supracitados. Desse grupo, o Japão é o país com os maiores custos de produção, destacando-se o peso elevado da MDO nos custos totais. As principais vantagens do Brasil estão nos custos da MDO e de energia, e as desvantagens nos custos de capital - item onde o país perde, inclusive para a Índia, e que representa a maior parcela dos custos totais de produção.
} 
O algodão representa $90 \%$ de todas as fibras naturais utilizadas no Brasil (Haguenauer et $a l, 2001)$. A proporção de tecidos feitos de algodão no Brasil chega a $65 \%$, muito superior aos 50\% encontrados nos países europeus, por exemplo (Lafis, 2001 apud Prochnik. 2002). Do total de roupas confeccionadas no país, $75 \%$ são feitas a partir do algodão, de acordo a ABRAVEST. Com destaque para roupas de malha de algodão, produtos em que o Brasil é o terceiro produtor mundial (Gorini, 2000), ficando atrás somente dos Estados Unidos e da China.

No final dos anos 80, a praga do bicudo destruiu as plantações de algodão no Nordeste brasileiro, passando o país, em 1992, de grande produtor a ser um dos maiores importadores. Uma importante relocalização dos cultivos está acontecendo no Centro Oeste e, principalmente, no estado de Mato Grosso, onde os índices de produtividade são comparáveis aos da Turquia e os custos de produção só maiores que os da China. Esta elevada produtividade deve-se às condições ambientais e às estratégias conjuntas de governo e empresários, que incluem pesquisas tecnológicas para o melhoramento das variedades e do cultivo e sua transferência aos produtores. A partir de 1997, as importações começaram a cair (Gorini, 2000) e o Brasil começa a ressurgir como exportador (Prochnik, 2002). A tabela 2.31 apresenta, a seguir, a evolução da produção das principais fibras produzidas no Brasil: 
Tabela 2.31 - Produção de fibras têxteis no Brasil, 1985/2000(mil ton.)

\begin{tabular}{|c|c|c|c|c|}
\hline Ano & Algodão & Artificiais & Sintéticas & Total Geral* \\
\hline 1985 & 968,0 & 46,6 & 204,0 & 1.321 .6 \\
\hline 1986 & 793,0 & 50,4 & 239,2 & $1.184,8$ \\
\hline 1987 & 633,0 & 48,0 & 322,0 & $1.116,7$ \\
\hline 1988 & 864,0 & 51,5 & 317,9 & $1.357,2$ \\
\hline 1989 & 709,3 & 55,1 & 317,8 & $1.160,3$ \\
\hline 1990 & 665,7 & 54,7 & 280,8 & $1.064,2$ \\
\hline 1991 & 716,9 & 52,9 & 304,7 & $1.128,9$ \\
\hline 1992 & 667,1 & 54,2 & 294,8 & $1.075,8$ \\
\hline 1993 & 420,0 & 56,8 & 322,8 & 855,4 \\
1994 & 483,1 & 58,6 & 346,1 & 938,8 \\
\hline 1995 & 537,1 & 53,1 & 335,3 & 966,9 \\
\hline 1996 & 410,1 & 34,3 & 333,0 & 821,7 \\
\hline 1997 & 305,8 & 36,5 & 350,7 & 734,4 \\
\hline 1998 & 411,5 & 29,1 & 366,8 & 835,6 \\
\hline 1999 & 520,6 & 34,6 & 411,5 & 985,6 \\
\hline 2000 & 700,3 & 36,4 & 467,1 & $1.228,8$ \\
\hline
\end{tabular}

Fonte: Extraído de Prochnik, 2002, elaborado pela ABIT com dados de CONAB, ABRAFAS e AFIPOL.

* O total inclui outras fibras naturais.

Já o dinamismo recente da indústria de fibras químicas no Brasil também parece estar associado às modificações nas políticas de comércio exterior e a uma reação ao embate causado pela abertura de mercado para importação que ocorreram nessa ocasião. É necessário ressaltar a influência das empresas multinacionais, precursoras neste segmento no país, cujas decisões são tomadas de acordo com as estratégias globais das matrizes.

Tanto as empresas subsidiárias quanto as nacionais foram afetadas pelas dinâmicas externa e interna e tiveram que repensar suas estratégias de mercado e investimentos. Essa reestruturação levou as subsidiárias à definição de nichos de mercado-alvo mais 
especializados ${ }^{37}$ e a novas estratégias de comercialização e relacionamento com seus clientes.

A reestruturação trouxe à cena novos investimentos nacionais (normalmente pela compra de unidades ou frações das subsidiárias) e também de novos investimentos internacionais.

Algumas subsidiárias, que não saíram totalmente da produção, se especializaram e fizeram alianças estratégicas com empresas a montante, tornando-se importantes prestadoras de serviço e recuperando, assim, importância no novo contexto nacional. Em determinadas circunstâncias, as subsidiárias tornam-se importadoras e revendedoras de produtos fabricados em outras plantas da empresa, localizadas em alguma outra parte do mundo, as empresas importam produtos semi-elaborados como os "Fios Parcialmente Orientados" - POY (Partly Oriented Yarns) e multi filamentos, que sofrem a texturização de acordo com as demandas locais.

As estratégias visam a diferenciação de seus produtos dos asiáticos - mais baratos -e/ou o preenchimento de nichos ainda vagos ou novos.

Já as empresas de capital nacional apostam em nichos intermediários, produzindo uma diversidade de fibras químicas (pseudocommodities) em processos de tipo batelada (“batch”), atendendo às médias empresas produtoras de tecidos, cujas demandas não são satisfeitas pelas subsidiárias nem pelos importadores. As maiores dificuldades manifestadas pelas empresas têxteis são os prazos de entrega, o pequeno volume das ordens e a falta de disponibilidade do crédito.

\footnotetext{
${ }^{37}$ Entre as principais destacam-se orientações de suas linhas de produto e produção para especialidades e inovações, fibras de alto valor agregado, em geral defendidas por patentes e comercializadas com altos investimentos na divulgação de marca. No sentido definido anteriormente, ou seja, as fibras que seriam classificadas como pseudocommodities e as especialidades propriamente ditas.
} 
Observa-se, ademais, nestas empresas nacionais fornecedoras de fibras químicas, que o foco está mais na produção do que no produto ou no serviço (Fleury, Fleury, CruzMoreira et al, 2001).

Entre as empresas produtoras integradas à montante: fiações, malharias e produtoras de tecidos, destacam-se grandes grupos especializados, os quais, além de suprir o mercado interno, são grandes exportadores: Vicunha, Coteminas e Santista, que representam juntos a terça parte das exportações brasileiras da CPTV (Prochnik. 2002).

Estas empresas trabalham a partir da fiação com misturas de fibras naturais e sintéticas para satisfazer às demandas dos clientes e consumidores finais, atuam com marcas próprias e também como produtores de insumos/produtos finais (vestuário padrão) para outras companhias nacionais e internacionais, através de sub-contratações, licenciamentos e fornecimento de matérias primas.

Destaca-se a estratégia multinacional da Santista: com produção na Argentina e no Chile, além de cobrir o MERCOSUL, no Chile são consideradas as vantagens de exportação para os Estados Unidos.

\subsubsection{O elo do meio: empresas produtoras de tecidos e de roupas}

O elo do meio, o da manufatura de tecidos e confecção de roupas, é heterogêneo e pulverizado em extremo, sendo constituído por 3.305 tecelagens e malharias e 18.797 confecções (Tabela 2.23).

No setor têxtil, muitas tecelagens especializadas em tecidos sintéticos deixaram de fabricar tecidos para o vestuário e passaram a fabricar tecidos para revestimentos e decoração, tanto pelo equipamento quanto pela árdua concorrência exterior que faz pouco rentável e muito competitivo o nicho dos tecidos de vestuário de moda. 
Contudo, algumas empresas se modernizaram e, em parceria com as produtoras de fibras e os estilistas, inovam e lançam tecidos de alto valor agregado para este segmento, que serão tendências para os nichos mais populares e que competem com os importados.

A empresa Guadalajara S.A. Indústria de Roupas, do grupo Claudino, sediada em Teresina, Piauí, é um caso excepcional quanto a sua lo calização, tamanho de empresa (1.720 empregados), capacidade de produção (4 milhões de peças/ano) e exportações, chegando a fabricar 1,2 milhões de peças para a francesa Jou Jou, e as americanas Calvin Klein, Ralph Laurent e Wal-Mart.

Em 2002, 450.000 peças de roupas com a marca Guess e 2.500.000 com a marca Gloria Vanderbilt foram exportadas. A empresa espera faturar, em 2003, R\$.50 milhões, dos quais US\$ 7 milhões vindos da exportação. O equivalente a $97 \%$ das exportações são de marcas dos clientes. Seus principais mercados são os Estados Unidos, o Mercosul e Japão.

No Brasil, seus principais clientes são a rede de lojas do próprio grupo (3\%, para o qual foi criado), lojas multimarcas (80\%) e as lojas de departamentos com, 13\%. A empresa também produz sua marca original de jeans Onix, que foi criada para suprir a rede de varejo do grupo (Veríssimo, 2002). Além do próprio grupo, tem entre seus clientes a Renner, a cadeia de supermercados Bompreço, entre outras.

\subsubsection{O elo da Comercialização}

A produção e comercialização de vestuário no país são extremamente pulverizadas, existindo cerca de 20 mil marcas comercializadas. (Gazeta Mercantil, 1999). Pelo mercado concorrem, além das empresas estabelecidas formalmente, contingentes equivalentes de empreendedores na economia informal, desde costureiras domiciliares e sacoleiras até as mais badaladas e caras representações internacionais. 
O varejo de roupas brasileiras enfrenta e desafia as estratégias das empresas transnacionais, tanto no nível das lojas de departamentos, redes especializadas ${ }^{38} \mathrm{em}$ artigos de vestuário e inclusive "griffes" nacionais, que cada dia alcançam maior destaque com o seu ênfase no design e nas atividades relacionadas à moda.

Assim como o restante do varejo, o de vestuário é um setor muito dinâmico e catalisador da reestruturação de toda a CPTV, modernizando suas estratégias de fornecimento, que tanto podem escolher entre os produtores nacionais ou os estrangeiros.

Tratar-se-á com maior detalhe do elo da comercialização quando se analisem as trajetórias das empresas líderes de acordo com o modelo de Global Commodity Chains GCC.

Antes disso, apresenta-se um sintético panorama da atuação das empresas estrangeiras no país no nível da comercialização, como se fez como as produtoras de fibras manufaturadas.

\subsubsection{Empresas estrangeiras no Brasil}

No segmento jeans, as quatro marcas estrangeiras mais vendidas no Brasil - Levi's, Wrangler, Lee e Staroup - detinham juntas, em 2000, menos de 5\% do mercado nacional destes artigos. As estratégias destas empresas no Brasil são igualmente diversas, por exemplo, a Levi Strauss \& Co., que inicialmente atuou com confecção e distribuição próprias, em 2002 possuía mais de 200 pontos de venda entre exclusivos e multimarcas (de acordo com a empresa) ${ }^{39}$.

\footnotetext{
38 A concorrência nacional para empresas como esta pode ser representada pela Marisol, que atende mercados regionais e classes populares (Silvestrini, 2000).

${ }^{39}$ Seguindo a nova estratégia mundial da empresa, a filial no Brasil vem reduzindo sua produção própria local - a sede situada em Cotia (SP) desativou as principais linhas de produção - aumentando a
} 
Outra importante trajetória estrangeira no Brasil, da empresa Benetton, utilizou diferentes estratégias para adaptar-se ao mercado brasileiro: "inicialmente as roupas vendidas no país eram fabricadas por pequenas confecções nacionais, que nem sempre garantiam qualidade. Para resolver o problema, a Benetton construiu instalações próprias em São José dos Pinhais (PR)" (Fiora, 1997), visando uma adequação maior dos produtos e uma expansão para o MERCOSUL e a América Latina. Esta estratégia, assim como outras no mundo, não produziram os resultados esperados e a empresa acabou por restringir as atividades no país.

As empresas estrangeiras, mais recentemente, vêm adotando como estratégia a aquisição de marcas e empresas nacionais, tanto na produção quanto no varejo, para ingressar no mercado interno. É o caso da Sellinvest, grupo de investidores europeus que, no início da década de 1990, assumiu o controle da Vila Romana (que, como marca, surgiu nos anos 50) e da rede de lojas de mesmo nome. A fábrica fica situa da em João Pessoa, na Paraíba, o equivalente a $70 \%$ dos tecidos é comprado no exterior, sendo sua produção direcionada ao mercado interno nas lojas Vila Romana, que também comercializa produtos das marcas Pierre Cardin e Yves Saint Laurent, licenciadas da empresa desde os anos 70. Essas marcas representam $40 \%$ do faturamento da rede. A Vila Romana, inaugurada em 1988 para um público mais sofisticado, comercializa produtos das marcas Giorgio Armani, Ermenegildo Zegna e Grigio Perla (15\% das vendas), e produtos próprios confeccionados na Itália.

terceirização da confecção e dos serviços como lavagens e enxágües. Ademais, a empresa tem procurado, em nível global, concentrar seus canais de distribuição e aumentar o número de novas coleções, a fim de atingir um mercado de renda mais elevado.

Na reestruturação da empresa no Brasil, a Levi Strauss \& Co. ganhou a concorrência para filiais localizadas em outros países e trouxe para o Brasil produções que poderiam ser feitas no México ou na Ásia. Um dos motivos expressos pela direção da filial é a capacidade e qualificação da MDO brasileira (Gazeta Mercantil. 22 de novembro de 1999) que, mesmo terceirizada, continua em constante requalificação e melhorando suas capacidades e competências; ressalta-se, além do mais, um processo de terceirização bem sucedido sem os problemas de falta de qualidade, prazos, etc. Part e da produção da Levi's é terceirizada em cooperativas; uma delas, a Uniop, foi a primeira empresa a fabricar de forma terceirizada a produção da Levi's 501 na Latino-América, o denim continuava vindo da americana Cone Mills, em 2001 (Tessari, 2001). 
Diante da concorrência das empresas estrangeiras, algumas confecções brasileiras tornaram-se produtoras de roupas para outras marcas de moda ou gestoras de produção que atuam no segmento mais ligado ao nome de marca, moda e varejo especializado. Neste segmento as empresas brasileiras vêm reagindo bem com suas estratégias de design e posicionamento de marcas, como será visto adiante.

\subsubsection{Ambiente institucional das Cadeias Produtivas Têxtil-Vestuário CPTV brasileiras}

Aqui pretende-se destacar somente alguns dos pontos mais importantes do ambiente institucional em que as empresas brasileiras das CPTV se desenvolvem, além do grande e competitivo mercado, no qual há nichos dos mais diversos poderes aquisitivos.

Pela sua importância para o emprego, e dada a reestruturação e relocalização relatada por diversos níveis governamentais: federal, estadual e municipal, as indústrias constituintes das cadeias têm sido objeto de estudos e projetos de industrialização, geração de emprego, revitalização, etc, entre eles o Fórum da Competitividade, que reúne o governo e associações empresarias em diversas instâncias. Estes estudos pretendem gerar insumos para determinar as linhas de crédito que o governo deve apoiar, entre outros objetivos.

Na formação de recursos humanos, o Rio de Janeiro e São Paulo são sedes dos Centros de Tecnologia Têxtil e de Vestuário, CETIQT ${ }^{40}$ e CETVEST do SENAI, respectivamente. Instituições que também estão reestruturando-se para atender às demandas da indústria. As empresas privadas também realizam parcerias com centros de

\footnotetext{
${ }^{40}$ O CETIQT é um Centro de reconhecido nível internacional, com cursos de nível técnico têxtil, e superiores de Design e Engenharia Têxtil, recentemente inauguraram um MBA na área Têxtil e que organiza uma destacada Conferência Internacional sobre Têxteis e Vestuário a cada 4 anos. O CETVEST treina operários, técnicos e supervisores e estará formando a primeira turma de Gestores de Vestuário, com nível universitário, em 2003. Também iniciará proximamente um MBA em negócios do vestuário.
} 
ensino como a FEI - Faculdade de Engenharia Industrial - que tem um laboratório implantado com recursos das empresas de fibras sintéticas e de insumos químicos para a indústria têxtil; oInstituto de Pesquisas Tecnológicas - IPT também oferece serviços de testes de laboratório para a CPTV. A reabertura da Escola Têxtil do SENAI ${ }^{41}$, no Brás, promete ser um elemento de dinamização do setor (Garcia et Cruz-Moreira, 2003) a partir de São Paulo.

$\mathrm{Na}$ pesquisa, a formação de recursos humanos foi considerada deficiente e as competências destes centros bastante ignoradas (Fleury, Fleury, Cruz-Moreira et al, 2001). Apesar disso, em entrevista recente foi manifestada uma estreita cooperação entre as instituições de ensino e o empresariado, o que poderia indicar uma atualização das competências e missão das instituições educativas.

As opções para a formação de profissionais ao longo da cadeia estão se diversificando e aumentando. Em 1995 eram seis cursos de moda de nível superior, hoje há 34 relacionados à moda, segundo dados do MEC. Há também cursos técnicos superiores e de Engenharia Têxtil - FEI-Têxtil. Outras instituições já oferecem cursos de pósgraduação na área, que vão desde o marketing ao jor nalismo de moda. $\mathrm{O}$ terceiro setor tem apresentado respostas à demanda de profissionais para a população carente.

O desenvolvimento tecnológico mais ligado à ciência pura e à inovação em materiais ainda está longe dos patamares dos países desenvolvidos e outros em desenvolvimento. As multinacionais trabalham mais com desenvolvimento e adequação de produtos do que com inovação.

Diversos tipos de estratégias estão sendo tomadas para melhorar a competitividade e aumentar as exportações, como é o caso dos cons órcios de exportação e as campanhas de marketing internacional apoiadas pelas associações empresariais e o governo.

\footnotetext{
${ }^{41}$ Serviço Nacional da Indústria, organismo federal, financiado pelo setor privado e atuante em quase todas as ramas industriais.
} 


\subsubsection{Estratégias para Progressão Industrial e competitividade nas Cadeias Produtiva Têxtil - Vestuário - CPTV brasileiras}

Apesar de serem consideradas indústrias tradicionais e de baixo conteúdo tecnológico, durante a última década as indústrias têxtil e de vestuário brasileiras têm sido muito dinâmicas, além de ter recebido muitos investimentos para a modernização do maquinário e para a utilização das novas tecnologias da informação, da logística e de Supply Chain Management - SCM, levando ao desenvolvimento do elo do varejo, cujas empresas líderes configuram quotas de governance antes cativas das empresas produtoras.

À jusante, a cadeia também se reestrutura e, juntas, as empresas locais enfrentam o desafio da competitividade internacional, tanto no mercado interno quanto no mercado internacional, com novas estratégias baseadas na eficiência coletiva, aprendizado e criatividade.

O predomínio das empresas nacionais no dinâmico mercado nacional e o recente sucesso de algumas marcas no exterior constituem evidências que apesar de/contudo e/ou por causa da crise inicial da abertura do mercado na década de noventa, está em curso nas cadeias produtivas têxtil-vestuário brasileiras um processo de Progressão Industrial, que leva a posições mais avançadas do que as esperadas para as empresas dos países em desenvolvimento.

$\mathrm{O}$ fato de que as marcas brasileiras comercializadas no exterior sejam de produtos mais sofisticados do que os tradicionalmente exportados em massa, e que ambas as exportações se realizem sem regimes tarifários preferenciais (exceto para o MERCOSUL) e ainda, apesar das barreiras, apontam para formas de inserção no mercado internacional de maior valor agregado. O que será avaliado na analise da pesquisa de campo. 


\section{CAPÍTULO 3}

\section{AS ABORDAGENS DE CADEIAS DE VALOR \\ E TRAJETÓRIAS DE PROGRESSÃO INDUSTRIAL}

\subsection{Globalização produtiva}

O processo de globalização, as novas tecnologias de informação e os requisitos de competitividade para a concorrência internacional têm provocado novas configurações para a produção industrial, em nível mundial. Nesta nova configuração, as empresas transnacionais têm um crescente e destacado papel, propiciando o desenvolvimento industrial. As atividades econômicas e produtivas passam de internacionais para globais e tornamse cada vez mais interdependentes e interconectadas. Para Dicken (1998) o ambiente internacional pode ser representado como uma "rede de interdependências" que envolve os governos dos países, organizações internacionais como a Organização das Nações Unidas - ONU, o Fundo Monetário Internacional - FMI, a Organização Internacional do Comércio - OMC e organizações transnacionais, entre elas as Organizações Não Governamentais - ONGs, Empresas Transnacionais - TNCs, Associações/Sindicatos Comerciais Internacionais e Grupos Ambientalistas, entre outros. 
No nível da produção e do comércio internacional, são as grandes corporações globais que determinam o que, como e onde será produzido um determinado produto. Elas descentralizam e alocam as operações de fornecimento de insumos, manufatura e distribuição para outras empresas em diversos países, liderando assim os fluxos de produção, fornecimento e comercialização em nível mundial.

De acordo com Fleury et Fleury (2002) uma das principais características da nova economia é a transição da eficiência individual para a eficiência coletiva. A competitividade é e será cada vez mais relacionada ao desempenho de redes interempresariais, e incluirão outras instituições além de empresas e associações empresarias, governo nas suas diferencias instâncias e instituições de pesquisa e universidades.

\subsubsection{Relocalização internacional da produção}

Para a elaboração do modelo de cadeias de adição de valor, os autores têm se baseado na análise das trajetórias de empresas, países e momentos importantes da relocalização da produção internacional.

Pode-se dizer que a evolução se deu com a relocalização mundial da produção na indústria do vestuário e em outras indústrias no séc. XX - em um primeiro momento, na década de 50 e começo dos anos 60 - dos países industrializados para o Japão. Em seguida, nas décadas de 70 e 80, do Japão para os Tigres Asiáticos [Hong-Kong, Taiwan, Coréia do Sul, e Cingapura (Dickerson, 1999) $]^{42}$.

\footnotetext{
42 Países de Recente Industrialização, mais conhecidos como NICs (New ou Newly Industrialized Countries ou ainda NIEs: Newly Industrialized Economies). Amsden (1989) inclui o Japão como um caso ímpar entre os países do "paradigma da industrialização tardia" e a Coréia do Sul, Taiwan (países do Milagre Asiático), Brasil, Índia e, possivelmente, o México e a Turquia, mas diferencia Hong-Kong e Cingapura por serem cidades -estados cuja transformação industrial não começou numa atividade agrária, nem na produção de matérias -primas.
} 
Em meados da década de 80, outra grande movimentação da produção aconteceu, desta vez partindo principalmente dos Tigres Asiáticos para outros países em desenvolvimento, principalmente para a China e o Sudeste Asiático, e também da Europa para a Turquia.

Na década de 90, uma proliferação de novos fornecedores, por causa da consolidação dos blocos comerciais, se dá dos Estados Unidos para a América Central e o Caribe, mas principalmente México, por causa do NAFTA. Aos fornecedores para a União Européia somaram-se os países do leste europeu, depois da queda do muro de Berlim.

Apresentam-se, a seguir, o caso da triangular asiática, que foi a primeira grande relocalização, no século XX, a ser estudada para fundamentar os modelos que serão utilizados neste estudo.

\footnotetext{
Para efeitos deste trabalho e seguindo o modelo de Dickerson (1999), "the Flying Geese", inclui-se o Japão, entre os países industrializados, pela sua trajetória pioneira na Ásia e a liderança exercida sobre o outros países na industrialização: os NICs Asiáticos: Hong-Kong, Taiwan, Coréia (do Sul) e Cingapura; a segunda geração de NICs Asiáticos é formada pelos fundadores da Association of Southeast Asian Nations - ASEAN (exceto Cingapura, já destacada entre os NICs): Indonésia, Malásia, Filipinas, Tailândia e Brunei. A estes seguiram-se os novos membros da ASEAN: Vietnã, Myanmar e Laos.
}

No Sul da Ásia: Índia, Paquistão e Bangladesh, junto a Sirilanka, Nepal e Butah, constituem outro grupo da maior importância no comércio internacional de têxteis.

Junto à China, a partir da segunda geração de NICs, os países também são chamados de emergentes, no bloco de países asiáticos.

Os NICs Latino-americanos são o México e o Brasil, tendo como maior destino de mercado os Estados Unidos, principalmente o primeiro que, junto com o Canadá, formam o NAFTA. Os países da América Central e do Caribe, quando necessário, serão agrupados como países da IBC por causa da importância deste marco legal para o comércio regional com os Estados Unidos, seu mais importante mercado.

O outro grande bloco comercial está constituído pela União Européia, e sua área de influência e fornecimento de MDO são constituídas pelos países da Europa do Leste e suas ex-colônias ao redor do globo, ademais da Turquia. 


\subsubsection{Subcontratação e Manufatura Triangular Asiática}

No Japão a subcontratação foi utilizada como estratégia de industrialização e desenvolvimento. Esta estratégia possibilitou o aprendizado industrial, aquisição de tecnologia, know-how de gestão e o conhecimento de mercados necessário para a inserção dos produtos japoneses no comércio internacional. Em 1966, em torno de 310.000 pequenas e médias empresas $(56 \%$ dos estabelecimentos de manufatura industrial) eram subcontratadas por uma empresa maior, empregando 3,6 milhões de trabalhadores, equivalentes a mais de um quarto da força de trabalho na manufatura (Watanabe, 1971,1978).

O sistema empresarial japonês tem no processo de aprendizagem seu fundamento (Fruin, 1992), apesar da sua segmentação e rivalidades. Uma característica muito importante são as "fronteiras permeáveis" (Fleury et Fleury, 1995) que possibilitam processos intensos de cooperação entre as empresas que podem envolver capital, informações, recursos humanos e insumos.

De forma simplificada, as redes interempresariais japonesas podem ser classificadas em três tipos (Fleury et Fleury, 1995): grande agrupamentos horizontais de empresas de diferentes indústrias e setores - chamadas Kigyo Shudan (nova designação para os anteriores Zaitbatsu); agrupamentos verticais de empresas gradativamente menores, lideradas por grandes empresas como a Toyota - chamados Keiretzu e os novos agrupamentos ad hoc, no qual as empresas realizam coordenadamente uma task force num período de tempo limitado.

Os Keiretzu representam uma forma particular de se organizar as relações entre as empresas e têm, entre seus fundamentos: uma participação acionária cruzada, filiação conjunta a um mesmo banco, diretorias e cargos de comando também cruzados, processos de consultas técnica e gerencial recíproca e, principalmente, relações estáveis de fornecimento entre empresas-clientes (Amato, 1993). Os Keiretzu liderados pela 
empresa "mãe", ou montadora, e muitos níveis de empresas subcontratadas são geralmente integrados verticalmente em indústrias específicas como os grupos Toshiba, Toyota e Sony (Dicken, 1998).

Estes complexos grupos podem tomar a forma de arranjos interempresariais horizontais altamente diversificados, organizados em torno de duas empresas centrais: um banco e uma empresa comercial (Sogo Shosha), como é o caso dos grupos Mitsubishi, Mitsui e Sumitomo, derivados substitutos dos anteriores Zaibatsu. Os outros importantes Keiretzu horizontais são liderados por bancos. (Dicken, 1998). Estes dois tipos de estruturas não são mutuamente exclusivos e podem interligar-se em arranjos mais complexos.

No período do pós - guerra, em que esta reestruturação foi feita no Japão, as médias e pequenas empresas fornecedoras foram classificadas pelo seu nível de capacitação tecnológica e pela sua capacidade produtiva. Organizando-as numa estrutura hierárquica piramidal, a empresa montadora de produtos finais se localiza no topo, encomendando das fornecedoras subcontratadas de primeiro, segundo e terceiro (flutuantes) nível, as matérias-primas, peças e componentes necessários para a montagem final.

Rapidamente muitas empresas fornecedoras de pequeno e médio porte passaram a fortalecer-se, aumentado seu poder de negociação frente às grandes empresas contratantes, tornando-se importantes tomadores de pedidos internacionais dos países desenvolvidos.

Foi assim que o Japão evoluiu, quando os seus custos de produção e o valor de sua força de trabalho aumentaram, muitas atividades foram transferidas para países próximos, mais conhecidos como os NICs asiáticos ou Tigres Asiáticos. O progresso do Japão, veio a ser o modelo para esses países, que em grande medida basearam o seu inicial desenvolvimento nas indústrias têxtil e de vestuário. 
O Japão foi o primeiro a mover sua indústria para setores de alta tecnologia, intensivos em capital, transferiu para as outras economias asiáticas a riqueza e a experiência em todas as indústrias, porém particularmente nas têxteis e de vestuário. Foram as empresas japonesas as primeiras a ter capital para investir em seus vizinhos menos desenvolvidos, para onde se transferiram primeiramente os segmentos intensivos em MDO das indústrias têxtil e do vestuário (Dickerson, 1999). Novas oportunidades se apresentaram para a força de trabalho mais capacitada e para um mercado mais rico.

A relocalização produtiva asiática descrita acima, que se dá por causa do aumento dos custos de produção no Japão e nos Tigres Asiáticos e pelo posicionamento de suas empresas em elos com atividades que adicionam maior valor aos produtos finais, exportados para os mercados Americano e Europeu, é conhecida também como Produção Triangular (Gereffi, 1999).

A segunda relocalização das atividades de produção das empresas asiáticas, tanto do Japão e dos Tigres como também de países da ASEAN, é mais do que uma tentativa de aproximação dos mercados, por causa da necessidade de resposta rápida ao cliente ${ }^{43}$ nos mercados centrais e por causa de mais baixos salários e condições de infra-estrutura na periferia próxima a eles. É uma resposta às estratégias de fechamento em bloco dos Estados Unidos e da União Européia. Muitas restrições foram impostas às importações da Ásia para proteger as indústrias locais nos países industrializados, os quais outorgaram "privilégios" aos países menos desenvolvidos dentro dos blocos comerciais e quotas a outros países sob à sua influência comercial e política, como é o caso do NAFTA e da IBC.

\footnotetext{
${ }^{43}$ A produção em pequenos lotes, que demandam flexibilidade e resposta rápida, ainda estava em mãos de empresas locais nos países desenvolvidos. Em muitos casos, certos nichos de mercado ainda continuam cativos em empresa locais, que atuam nos subúrbios dos principais centros de moda, como é o caso de New York e Los Angeles.
} 
Na figura 3.1 de acordo com o exemplo de McCormick et Schmitz (2002): o "comprador internacional" poderia ser uma empresa varejista estadunidense que encomenda um produto a um fornecedor de vestuário de Taiwan, que para obter um preço competitivo, por sua vez encomenda total ou parcialmente essa produção a um produtor de um país com menor custo de MDO, como Vietnã. O triângulo completa-se quando a encomenda é embarcada diretamente do produtor vietnamita para o cliente estadunidense.

No caso dos países da IBC, a ordem poderia ser de um varejista estadunidense que encomenda a um tradicional fornecedor coreano que possui filial ou parceiros de produção na América Central ou no Caribe.

Fig.3.1 -

Produção triangular

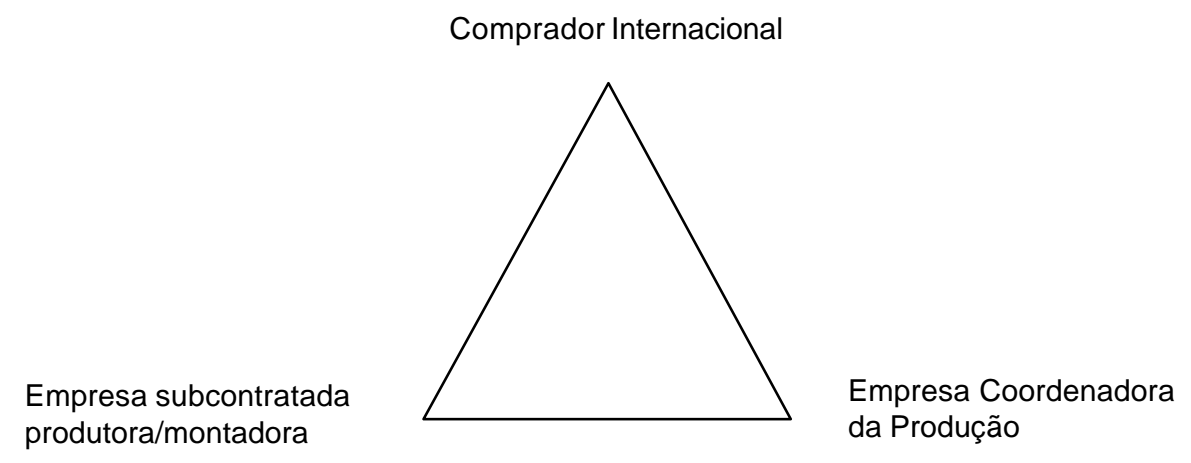

Fonte: Adaptado de McCormick et Schmitz, 2002. 


\subsection{Cadeias Globais de Formação de Valor}

\subsubsection{Antecedentes}

Até hoje, a maior parte da literatura que analisou as redes de fornecimento é baseada em observação descritiva e nas grandes empresas, mas ainda precisa explicar melhor como acontece a eficiência coletiva nas redes inter-organizacionais (Fleury et Fleury,1995).

Para estes autores, as redes de fornecimento são parte das redes inter-organizacionais e consistem de entidades interconectadas e cujo propósito primário é a obtenção, uso e transformação de recursos para prover pacotes de bens e serviços. Através dessas redes, bens e serviços são levados das fontes originais de produção/extração aos consumidores finais.

Cadeias de produção industrial sempre existiram. A diferença é que atualmente as etapas de produção localizam-se de forma mais dispersa, em diferentes partes do globo. As organizações que delas participam mudaram, assim como mudaram também as hierarquias e as formas de se estruturar os fluxos de produção.

Nas indústrias mais tradicionais, os mercados evoluíram e novos países se tornaram os principais mercados fornecedores, também com poder de compra, recentemente chamados de economias emergentes.

Desde os tempos em que na maioria dos continentes existiam colônias, principalmente das potências européias, o mapa e o fluxo de matérias-primas, insumos e produtos acabados foram muito modificados.

Os sítios de fornecimento foram mudando e os países fornecedores de matérias-primas evoluíram, trilhando diversas trajetórias. As mais recentes e das quais se analisam seus 
efeitos são a de substituição de importações e a de exportação realizadas pelos países em desenvolvimento no século passado.

Assim, o projeto pode ser realizado num sítio, a fonte das matérias-primas pode estar localizada em outro, a produção realizar-se em regiões distantes ou ainda em diferentes países, da mesma forma que os mercados estão dispersos pelo mundo inteiro.

Mais do que os sítios de produção, mudaram também os atores, quem dirige e quem detém o poder, quem executa o trabalho e quem obtém maior resultado/valor por ele. Não são mais os reis e suas armadas navais que controlam o comércio internacional, mas são, primordialmente, as empresas privadas, que evoluíram de empresas com atuação local ou nacional a empresas primeiro multi e depois transnacionais, hoje constituídas pelas corporações globais.

As funções que agregam valor aos produtos também são diferentes hoje. O domínio daquelas competências relacionadas com o conhecimento e o mercado são as que permitem, a quem as possui, adicionar e receber mais valor por isso.

Na segunda metade do século XX, o sistema global de produção e comercialização mudou aceleradamente e foi mais notório nas últimas duas décadas. A sua organização tem sido explicada por vários modelos, mas o conceito de Global Value Chains - GVC, ou Cadeias de Formação de Valor, é o que recentemente tem sido utilizado com maior consenso

A metodologia de Cadeias de Formação de Valor tenta modelar todo o leque de atividades que são necessárias para, ao final de um processo de produção, ofertar um produto. Incluem-se aí a sua concepção através do projeto, a fonte e os mecanismos de fornecimento de matérias-primas, os insumos intermediários e os serviços prestados por indústrias correlatas ou de apoio, as diferentes etapas produtivas e, ao final, as atividades de marketing, a distribuição e também os serviços de suporte pós-venda ao consumidor 
final, que atualmente, em muitos casos, agregam maior valor do que as atividades produtivas, por exemplo, o prestígio de uma marca famosa e confiável.

Desta forma, como afirmam Raikes, Jensen et Ponte (2000) e Kaplinsky (1998), todas essas atividades são vistas como uma cadeia interconectada de produção, comercialização, distribuição e consumo de produtos e serviços.

O conceito de value chain foi usado, nos anos 60 e 70, para mapear o caminho de desenvolvimento de economias exportadoras de minérios (Girvan, 1987). Traduzido ao francês como "filière", foi adotado na literatura de planejamento e usado nos anos 70 e 80 para descrever as capacidades necessárias para a indústria francesa percorrer completamente a linha de uma cadeia de valor. O conceito de filière sugeria que a totalidade das atividades fosse realizada dentro das fronteiras nacionais.

O trabalho de Porter (1985) conferiu-lhe destaque inicial como modelo analítico, por meio do conceito de Multi-linked Value Chain, ao qual se refere como sistema de valor.

\subsubsection{Cadeias Globais de Produção - Global Commodity Chains - GCC}

Uma outra vertente destaca que nestas cadeias produtivas, um ou alguns participantes possuem maior poder, mediante o domínio de atividades especializadas, e exercem coordenação e controle sobre os outros participantes.

A partir da definição de Hopkins et Wallerstein (1986, apud Hopkins et Wallerstein, $1994){ }^{44}$ para quem Commodtty Chain é uma rede de processos de produção e de trabalho

\footnotetext{
${ }^{44}$ Hopkings et Wallerstein (1986) teorizam e começam a definir as variáveis deste modelo. Uma sín tese introdutória é apresentada, assim como a evolução de algumas cadeias de produção antes de 1800, como a da farinha de trigo (Pellizon) e a construção de navios (Ö̈zveren) no livro "Commodity Chains and Global Capitalism", editado por Gereffi et Korzeniewicz (1994). Entre as cadeias de produção contemporâneas sistematizadas nesse volume, estão a automobilística, comparação entre Coréia, o México e o Brasil (Lee
} 
a qual resulta em uma mercadoria acabada. Outros autores teorizam e começam a definir as variáveis deste modelo analisando, sob o marco teórico do sistema mundial, a evolução de algumas cadeias de produção agrícola antes de 1800, como a da farinha de trigo e também a construção de navios.

"Todas as firmas ou unidades de produção recebem insumos (input) e os transformam em produtos finais (outputs). A transformação dos insumos que resulta em produtos finais, localiza estas firmas dentro de uma cadeia de mercadorias (ou, com freqüência, em múltiplas cadeias de mercadorias). Em termos da economia mundial capitalista, cadeias de mercadorias podem ser pensadas como o urdume e a trama do sistema da produção social. Ao traçar as redes dessas cadeias de mercadorias, pode-se seguir a divisão e integração atual de processos de trabalho e assim monitorar a transformação constante e o desenvolvimento do sistema de produção da economia-mundo" (Hopkins et Wallerstein, 1994, p.17).

O modelo denominado Global Commodity Chains - GCC, é consolidado por Gary Gereffi e outros autores (Appelbaum et Gereffi, 1994; Gereffi, G. et Kornzeniewicz, 1994; Gereffi, 1994; 1999), principalmente nas cadeias de produção nas indústrias têxtil e de vestuário. Para isto, esses autores e também Bonachic et al (1994), Appelbaum, Smith et Christersen (1994), se baseiam no estudo das novas cadeias constituídas por firmas participantes e sediadas em países localizados ao redor do oceano Pacífico, como também nas transformações ocorridas nas cadeias constituídas por empresas do México e dos Estados Unidos, (Gereffi, 2000) antes e depois de iniciado o Acordo de Livre

et Cason); assim mesmo a cadeia de produção de frutas do Chile para os Estados Unidos (Golfrank), e a de sapatos desportivos (Korzeniewicz). 
Comércio da América do Norte, e naquelas em que participam empresas da América Central e do Caribe ${ }^{45}$.

Esta abordagem metodológica ganha destaque porque envolve aspectos de poder, dimensão já identificada em outros modelos de análise, porém que aparece como prioritária na abordagem conceitual de Global Commodity Chains - GCC, e assim enunciada (Appelbaum et Gereffi, 1994: p.43):

"Uma cadeia global de produção consiste em elos ou operações que compreendem pontos pivotais nos processos de produção, fornecimento de matérias-primas, produção e exportação; cruzando todo o espectro de atividades da economia mundial. Cada elo é por si mesmo uma rede conectada a outros elos, responsáveis por atividades correlatas. Tais redes de exportação são de importância crescente no sistema de manufatura global contemporâneo".

A idéia central é que as cadeias produtivas têm estruturas de comando (governance) na qual uma ou mais empresas coordenam atividades econômicas geograficamente dispersas. A racionalidade econômica na cadeia produtiva vem do fato de que a(s) empresa(s) que comanda(m) a cadeia busca(m) dominar as atividades que são estratégicas e que agregam mais valor (Fleury et Fleury, 2000).

No modelo de GCC distinguem-se dois tipos de cadeias. As do primeiro tipo "Producer Driven Chain" - PDC, são aquelas nas quais grandes e integradas empresas industriais detêm o controle do sistema de produção, inclusive suas conexões para frente

\footnotetext{
${ }^{45} \mathrm{O}$ modelo sobre as cadeias produtivas foi aprofundado pelo estudo do caso da indústria do vestuário cujos produtos finais têm, como destino, o mercado dos Estados Unidos. Sob esta ótica, por vários autores, muitos destes estudos foram apresentados no volume organizado por Edna Bonacich, Lucie Cheng, Norma Chinchilla, Nora Hamilton et Paul Ong no livro "Global Production; the Apparel Industry in the Pacific Rim” (1994), que inclui as cadeias de produção de vestuário integradas por firmas dos Estados Unidos e dos países da bacia do Oceano Pacífico e também do México, da América Central e do Caribe. Assim como indústria do vestuário nos Estados Unidos é também descrita nesse volume.
} 
e para trás. As indústrias automobilística, de computadores, aeronáutica e de máquinas elétricas, intensivas em capital e tecnologia, são características neste tipo de cadeias produtivas que, usualmente, são comandadas por empresas transnacionais. Esta estrutura é representada pela figura 3.2 a seguir ${ }^{\mathbf{4 6}}$.

Figura 3.2 - $\quad$ Cadeias lideradas pelos produtores (Producer Driven Chains)

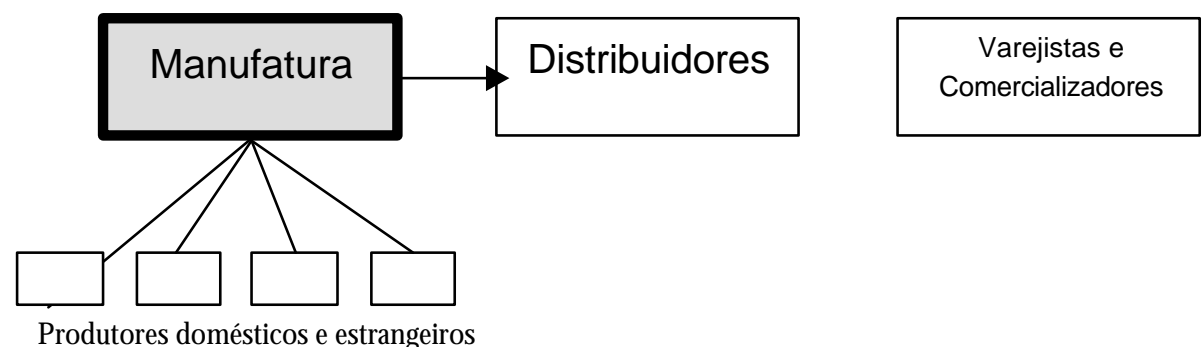

Fonte : Adaptada de G ereffi, 1994.

As do segundo tipo - "Buyer Driven Chain” - BDC, envolvem aquelas indústrias nas quais grandes varejistas e vendedores de marcas famosas (brandnamed marketers) têm um papel central no cenário das redes de produção, descentralizada em vários países exportadores, tipicamente localizados no terceiro mundo. Este padrão de industrialização, liderado pelo comércio é, com freqüência, intensivo em MDO, ao menos em alguma de suas etapas, e característico das indústrias de bens de consumo como roupas, calçados, brinquedos e componentes eletro-eletrônicos. As BDCs são representadas na figura 3.3, na continuação.

\footnotetext{
${ }^{46}$ Em ambas as figuras os campos sombreados indicam os elos e os tipos de empresas que detêm a governance nas cadeias.
} 
Figura 3.3 - Cadeias lideradas pelos compradores (Buyer Driven Chains)

Produção além-mar (nos países em desenvolvimento)
Compradores Globais (nos países centrais)

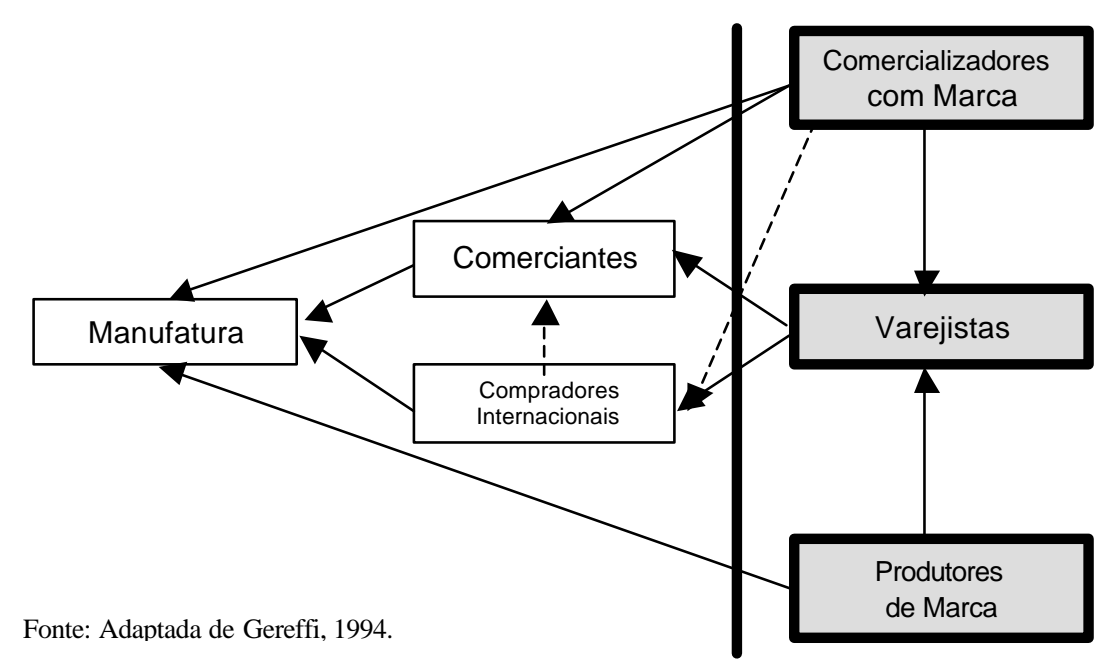

Já Abreu (1999) aborda essa distinção sob uma ótica global e financeira da seguinte forma: "O principal agente organizador desse novo capitalismo global são as corporações transnacionais, que podem estar organizadas segundo a lógica do capital industrial (cadeias organizadas por produtores) ou de capital comercial (cadeias organizadas por compradores)".

A primeira distinção deste tipo foi elaborada por Watanabe (1971), distinguindo a subcontratação como "comercial" e "industrial", quando relata os processos de subcontratação que propiciaram o desenvolvimento local e permitiram estruturar as cadeias de produção que, posteriormente, inseriram-se no comércio internacional. Esta distinção é fundamental para o processo de Progressão Industrial que aqui será discutido.

Ambos os tipos de cadeias, PDC ou BDC, sejam de produção industrial ou de serviços, organizam-se em função do mercado global. Em função da maior efetividade, integramse vários níveis de fornecedores também globais (fornecedores de $1^{\circ}, 2^{\circ}, 3^{\circ}, \ldots$ níveis), 
como é o caso da indústria automobilística, na qual o papel das montadoras é cada vez mais ligado ao design e projeto de produto, à gestão da cadeia de fornecedores e à comercialização.

\subsubsection{As variáveis do modelo de Global Commodity Chains - GCC}

Este modelo de análise apresenta quatro principais variáveis, que são:

- uma estrutura input-ouput, ou seja, um conjunto de produtos e serviços conectados numa seqüência de atividades que adicionam valor;

- uma dimensão territorial (geográfica), que mapeia a dispersão ou concentração espacial da produção e das redes de marketing e que abrange empresas de diferentes tamanhos e tipos;

- estrutura interna de governances, isto é, as relações de poder e autoridade que determinam como os recursos financeiros, materiais e humanos são alocados nas cadeias;

- um ambiente institucional, que pode ser local, nacional, regional ou global.

As duas primeiras - a seqüência de atividades e a dimensão territorial -, segundo Gibbon (2000), têm sido usadas descritivamente para destacar a configuração de cadeias específicas como Cadeias Globais de Produção de Vestuário - CGPV.

A dimensão geográfica é importante para entender a distribuição internacional da produção, comercialização e competição global. Para nós isso é relevante, pois nos estudos internacionais da produção de vestuário, o Brasil e a maioria dos países da 
América do Sul não têm sido considerados, e os países da Bacia do Caribe e da América Central, com raras exceções como Costa Rica (Mortimore et Zamora, 1998) e República Dominicana (Matews, 2002), são tratados de forma agregada (Mortimore, 2002; Dussel, 2001; Jenkins, Esquivel, et Larrain B.,1998; Gitli, 1997; CEPAL, 1998).

Nestas cadeias, o centro de gravidade da produção saltou dos Estados Unidos e da Europa para países como Coréia, Taiwan e Hong-Kong, passando de simples operações de manufatura a contratos "full-package" ${ }^{47}$, restando para outros países do sudeste asiático e do Caribe as operações mais simples de manufatura, que menos adicionam valor.

Para as empresas asiáticas, esta transição envolveu um extensivo processo de aprendizagem organizacional - que se deu na própria estrutura da cadeia - possibilitado pela estratégia de subcontratação que tinha como objetivo explícito este aprendizado. Adquiriram, assim, conhecimentos específicos sobre os compradores intermediários e o mercado final, requerimentos de qualidade, prazos e conhecimentos para a coordenação de fornecedores menores.

A dimensão geográfica está também relacionada com o ambiente institucional e político internacional. A crescente homogeneização dos mercados e dos padrões de consumo entre os diferentes países e regiões, a criação de grandes blocos comerciais, o Acordo Norte-americano de Livre Comércio - $\mathrm{NAFTA}^{48}$, a União Européia - UE e a Associação de Nações do Sudeste Asiático - ASEAN ${ }^{49}$, o Mercado Comum da América do Sul - MERCOSUL e a Área de Livre Comércio das Américas - ALCA, constituem

\footnotetext{
47 "Full-package" expressa a idéia de que o fornecedor entregue o produto acabado e realize ou coordene a maioria das atividades da cadeia produtiva, desde a busca de fornecedores de insumos, equipamentos e matérias-primas, atividades como modelagem, riscado e elaboração de protótipos, até a embalagem do produto acabado, incluindo as atividades de logística.

${ }^{48}$ Siglas em inglês.

${ }^{49}$ Siglas em inglês.
} 
um novo ambiente institucional regulado globalmente pelo Fundo Monetário Internacional - FMI e pela Organização Mundial do Comércio - OMC.

O modelo de Cadeias Produtivas Globais tem chamado a atenção devido à ênfase na definição da Estrutura de Poder. A estrutura de governances (poder) interna tem recebido maior atenção, uma vez que explica as relações de poder e de coordenação na cadeia, assim como as barreiras de entrada e de acesso às posições de liderança. A quarta dimensão, ou seja, o entorno onde as cadeias produtivas atuam, pode ser influenciado por aspectos institucionais (governos, acordos comerciais, universidades e escolas técnicas, instalações e infra-estrutura, entre outros), podendo ser de natureza local, nacional, regional, global, assim:

- Locais/nacionais: algumas cadeias americanas, brasileiras ou pequenas cadeias em todos os países.

- Regionais: aquelas onde somente estão envolvidas empresas de países de regiões definidas, como as de blocos comerciais como o NAFTA, o MERCOSUL, entre os EUA e a Bacia do Caribe e algumas cadeias operando só na Ásia.

- Globais: as que operam de uma forma mais dispersa e abarcam o mercado global, com operações em países de diferentes blocos e comercializando em todo o mundo.

- $\quad$ Bilaterais: quando só envolvem empresas ou operações em dois países. 


\subsubsection{Empresas líderes}

A metodologia de análise de GVC (Gereffi, Humphrey et Sturgeon, 2002) permite determinar quais empresas utilizam estratégias que possibilitam o comando da cadeia, estabelecendo as regras de funcionamento e definindo quem se apropria do valor gerado nos diferentes estágios do processo de produção e comercialização. Isto é particularmente relevante ao se considerar que os aspectos de comercialização, de acesso a mercados finais, conferem grande poder de barganha às empresas à jusante nas cadeias produtivas.

Nas cadeias produtivas dirigidas pelo mercado - BDC, dentre as quais se destacam as de brinquedos, calçados e vestuário, a produção é, a princípio, intensiva MDO e permite uma separação das atividades produtivas. Deste modo, elas são distribuídas espacialmente de forma rápida, econômica e eficiente por todos os confins do mundo, onde há recursos humanos disponíveis e com diversos graus de qualificação e custo.

Estas cadeias, cuja liderança é mais descentralizada que naquelas lideradas pelos produtores, têm como atores principais os produtores com marcas tradicionais de renome, grandes varejistas e cadeias de desconto, assim como designers e meramente comercializadores de produtos de marcas famosas. 


\subsubsection{Governance nas cadeias lideradas pelos compradores}

As atividades e funções de produção mais intensivas em MDO barata e menos intensivas em capital, como a costura no caso da indústria de vestuário e outros processos de montagem e transformação primária, são realizados prioritariamente em países menos industrializados e que apresentam vantagens de localização geográfica e de custo de $\mathrm{MDO}^{50}$.

Nesse novo contexto, como todos os setores produtivos, porém de maneira mais acentuada, as cadeias produtivas têxtil-vestuário, antes com um regime de mercado vendedor, passaram a ser "comandadas" pelos compradores. São cadeias nas quais os grandes varejistas, os comercializadores e os fabricantes de marcas globais desempenham papéis centrais, organizando redes de produção descentralizadas. Ao contrário das cadeias impulsionadas pelo produtor, a governance em cadeias comandadas pelo comprador não derivam da escala, do volume e dos avanços tecnológicos, mas sim, de combinações únicas de pesquisa de mercado, design, vendas, comercialização e serviços financeiros de alta qualidade (Gereffi, 1994).

Assim, cada cadeia produtiva na indústria têxtil-vestuário tem uma estrutura de governance - uma empresa ou um conjunto de empresas - que, por dominar posições estratégicas principalmente em relação ao mercado, estabelece como deverão comportarse as demais empresas participantes da cadeia e que resultados poderão almejar.

\footnotetext{
${ }^{50}$ Exceções também podem ser apontadas, como é o caso da atividade de design, intensiva em MDO, porém de alta qualificação e remuneração, geralmente localizada nos centros de decisão das cadeias produtivas. A produção de fibras sintéticas - atividade intensiva em capital - se realiza em países que já tiveram MDO barata, como os asiáticos Japão, Coréia, Hong-Kong e Taiwan, que foram estabelecidas nesses países como subsidiárias ou em parcerias com empresas locais (de acordo com as estratégias locais de industrialização de cada país) por serem, na época, centros produtores de tecidos e de roupas. Posteriormente, seu desenvolvimento em qualidade e diversidade, assim como escala de produção, foi estimulado para evitar restrições às exportações de produtos de algodão para os Estados Unidos e outros países desenvolvidos. Hoje, apesar da sobre-produção de fibras sintéticas, as grandes corporações transnacionais estão estabelecendo suas produções na China, para poder concorrer com os outros produtores asiáticos e estar perto das crescentes indústrias têxtil e de confecção chinesas. Os centros de pesquisa ainda estão sediados nos países industrializados.
} 
São os seguintes os modelos de organização de empresas que exercem a governance de cadeias produtivas na indústria têxtil-vestuário (Gereffi, 1994):

- Produtores com marca (Branded Manufacturers)

- Varejistas (Retailers)

- Comercializadores com marca (Marketers)

A seguir, apresenta-se uma síntese esquemática da estrutura das cadeias lideradas pelos compradores ou direcionadas pelo mercado, as BDC.

\subsubsection{Produtores com Marca (Branded Manufacturers)}

Esta categoria é também típica das cadeias lideradas pelos produtores, as PDC. Mas ainda há algumas empresas que lideram cadeias em setores industriais ou cadeias características do tipo $\mathrm{BDC}$, como é o caso das grandes indústrias produtoras de vestuário no Brasil. No entanto, nelas também observa -se, cada vez mais, a influência do mercado sobre as atividades produtivas e de serviços, mesmo naquelas intensivas em capital e tecnologia, como a DELL Computer, que passou a ser fornecedora de soluções customizadas em computadores.

\subsubsection{Varejistas (Retailers)}

As varejistas são aquelas empresas que primordialmente dedicam-se à comercialização de bens produzidos por empresas manufatureiras, cada vez mais influenciando a cadeia à montante. Sua vantagem em poder é decorrente do fato de dominar os estágios à jusante da cadeia, aqueles relacionados com o consumidor final. 


\subsubsection{Comercializadores com Marca(Marketers)}

Os comercializadores se baseiam no valor da marca, no design e no marketing. Entre eles alguns que nunca produziram nada, e que também não possuem infra-estrutura própria de varejo. Sua força se baseia na distribuição e na coordenação da cadeia de suprimentos, junto com as outras funções já mencionadas.

\subsection{Progressão Industrial ( Industrial Upgrading) e Modernização Industrial}

A capacidade para aprender e inovar são as indispensáveis competências que uma empresa deve possuir para enfrentar a competição na era do conhecimento. Mas como a competição não mais se dá entre as empresas individualmente, podemos dizer que é a competência ou habilidade que as redes e cadeias de empresas devem ter e buscar coletivamente.

Tratar-se-á, nesta seção, do conceito de Industrial Upgrading, conceito em voga que, traduzido literalmente para o português, significa aperfeiçoamento, melhoria, avanço (Collins Dictionary, 1986). Se traduzirmos "to upgrade” teremos: "elevar o nível de...", o que não satisfaz plenamente, em português, o significado do conceito de Industrial Upgrading, utilizado atualmente para representar os ganhos das empresas e das cadeias em relação às suas habilidades e competências.

Progresso ou desenvolvimento parecem corretos, mas banalizados pelo seu uso em momentos anteriores como progresso ou desenvolvimento industrial. Já o termo "progressão" (Houaiss et Villar, 2001) expressa as idéias de progresso, avanço e desenvolvimento e pode relacionar-se ao processo de industrialização de forma nova e mais positiva, por isso utilizar-se-á o termo "Progressão Industrial" para definir os 
estágios e trajetórias que percorrem as empresas atuantes nas cadeias de formação de valor contidas nesse conceito de Industrial Upgrading.

A notória influência das corporações globais, que dirigem estas redes de produção e comercialização mundial, assim como sua influência sobre os sistemas industriais nos países e regiões e sobre as condições sociais e econômicas, nos fazem pensar que as conseqüências das estratégias de industrialização não geram uma Progressão Industrial ou melhoria pra todas as pessoas, empresas ou países nessas redes e cadeias produtivas globais.

A seguir, apresenta-se a discussão baseada na literatura recente, comparando as diferentes vertentes da Progressão Industrial e como se relaciona esta abordagem com o modelo de cadeias de formação de valor.

\subsubsection{O conceito de Progressão Industrial}

Kaplinsky et Morris (2001) distinguem dois caminhos de inserção na economia global. A "rota baixa" é aquela de pouco crescimento, uma trajetória na qual produtores enfrentam uma intensa competição e são engajados numa "corrida para baixo".

$\mathrm{Na}$ outra direção, aqueles que têm percorrido a "via alta" exibiram a habilidade para entrar num círculo virtuoso de participação na economia global. Se a outra via é a oposta, pode ser que o círculo não seja virtuoso e que a competição seja cada vez mais precarizante.

A capacidade de inovação parece ser um importante diferencial entre os dois caminhos e teria o efeito de assegurar uma contínua melhoria no desenvolvimento de processos e de produtos. Se esse for o caso, então a ênfase deveria colocar-se na habilidade de 
apreender, o que tem implicações que vão além do setor produtivo nos países onde o aprendizado e a inovação ${ }^{51}$ aconteceram.

A via alta é plasmada na trajetória das empresas dos países industrializados que investem em inovação tecnológica e são intensivas em capital e conhecimento. A via baixa é aquela de setores intensivos em MDO e baixos salários, com pouca e/ou nenhuma inovação tecnológica e investimentos em conhecimento, característica dos setores de exportação de commodities.

Os países asiáticos são o modelo de um processo de industrialização no qual empresas conseguiram, a partir de atividades simples de montagem e manufatura intensiva em MDO barata e pouco qualificada, características da via baixa e que, depois de um processo de aprendizagem e melhorias contínuas, conseguiram passar para atividades da via alta, intensivas em capital e tecnologia e melhor remuneradas.

A trajetória destas empresas e redes de produção, que inspirou o modelo de Global Commodity Chains - GCC, também é utilizado para a formulação do modelo/trajetória de Progressão Industrial. Ademais, este processo é sistematizado na tipologia de Modernização Industrial apresentada a seguir.

\subsubsection{Progressão Industrial segundo Humphrey et Schmitz}

A abordagem mais apropriada para analisar o processo de Progressão Industrial, no contexto das redes interempresariais e cadeias de formação de valor, é a tipologia de “Industrial Upgrading” apresentada por Humphrey et Schmitz (2000).

\footnotetext{
${ }^{51}$ A inovação pode não ser adequada ou suficiente. Se a taxa de inovação for inferior a dos competidores, pode resultar num declínio do valor agregado e em perdas de fatias de mercado e, no caso extremo, um mísero crescimento. Isto será relacionado com os estágios de aperfeiçoamento apresentados anteriormente (OEA, OEM,...).
} 
Sob esta perspectiva, analisam-se desde as mudanças de mix de produtos e mudanças na natureza e composição de atividades dentro das empresas, até os deslocamentos ou mudanças de posicionamento nas cadeias de formação de valor. Estas mudanças podem incluir um nova configuração de funções e uma nova estrutura ou lógica de agrupamento e liderança nas cadeias como um todo.

Os autores identificam pelo menos quatro estágios ou posicionamentos nas trajetórias adotadas pelas empresas na busca do sucesso:

- Progressão Industrial em processos : melhor realização de tarefas específicas e o aumento da eficiência dos processo internos e em cada elo (p. ex., reorganizar os processos produtivos ou introduzir novas máquinas, reduzir rotação de inventários e o desperdício de insumos) e na cadeia (p.ex., entregas mais freqüentes, menores e no prazo).

- Progressão Industrial no produto: elaboração de um produto de melhor qualidade, mais sofisticado ou simplesmente mais barato, e ainda mais rápido que os concorrentes, o que implica em mudanças nos processos de desenvolvimento de produtos interna e externamente, quando isto envolve a cadeia. Por exemplo, a miniaturização do radio transistor, tornado-o, além disso, mais barato e acessível, ou produzir carros que utilizam combustível mais barato, ou da produção do telefone com fio à do telefone que não o utiliza.

- Progressão Industrial funcional: alcançar novos estágios, competências ou realizar outras funções p. ex., um produtor se encarregar também do design ou marketing; ou mover-se para eles. Ou ainda, aumentar o mix de atividades a serem produzidas pela empresa, que agreguem maior valor à cadeia como responsabilizar-se pela coordenação do outsourcing, controle (accounting), logística e qualidade. 
- Progressão Industrial de cadeias ou intersetorial: ocorre quando empresas aplicam a competência adquirida numa particular função dentro de uma cadeia para um novo setor (ex., marketing de exportação) ou numa nova cadeia de produção. Tal "translação" de habilidades para um novo setor parece ter um papel central para os países (como Taiwan) obterem um desenvolvimento em (de) setores que necessitam maiores habilidades (no caso: de produtores de rádio transistores para calculadoras, para televisores, para monitores de computadores, depois para laptops e agora para telefonia celular WAP). Enfim, competências adquiridas numa cadeia transladadas para atividades em outras.

Estes tipos de Progressão Industrial são interdependentes entre si, isto é, para entrar em um novo mercado, além de estratégias de marketing, parece necessário desenvolver capacidade para design próprio. Essa interdependência significa que as mudanças ou aprendizados em cada estágio vão influenciar a estratégia geral e possibilitar ou não a passagem para outro estágio.

\subsubsection{Progressão Industrial e seqüência de Modernização Industrial segundo Gereffi, fundamentada nas trajetórias de empresas dos Tigres Asiáticos}

Parte do sucesso dos Tigres Asiáticos é produto de um processo de aprendizado que se deve à orientação para a exportação que desde o início imprimiram ao processo de industrialização, à diversificação de seu tecido industrial e ao investimento em educação (Amsden, 1989). Depois de elevar as capacidades tecnológicas de suas empresas e de esgotar as quotas nacionais de exportação para os EUA e outros mercados, as empresas mais competitivas trasladaram suas funções de menor valor agregado e intensivas em MDO, primeiro para os Tigres Asiáticos, que posteriormente, por sua vez, repetiram esse movimento com outros países do leste asiático, sempre de forma coletiva, através da subcontratação. 
Para Gereffi (2000), o conceito de modernização industrial compreende vários níveis de análise relacionados entre si: as características do produto, os tipos de atividade econômica, as mudanças intra e intersetoriais, a tipologia que inclui a montagem e a fabricação de produtos originais (Original Equipment Manufacturing - $\mathrm{OEM}^{52}$ ), a fabricação de produtos de marca original (Original Brand Name Manufacturing ou Own Brand Manufacturers - $\mathrm{OBM}^{53}$ ) e a fabricação de projetos (design) originais (Original Design Manufacturing - ODM). O autor ressalta como um tipo de modernização industrial a progressão intra-setorial, ou seja, a aquisição de competências em encadeamentos para trás e para frente na cadeia produtiva. Considera, ademais, o deslocamento intersetorial de indústrias de baixo valor e de uso intensivo de MDO para outras de uso intensivo de tecnologia e capital.

A categoria Original Equipment Assembly - OEA, sugerida por Kaplinsky et Morris (2001), é pertinente por serem as competências (de produto, produção e gestão) necessárias para a montagem muito menores daquelas necessárias para a elaboração de um produto completo, mesmo que não o desenhe e que seja produzido por encomenda para os compradores ou varejistas de marca. É muito provável que em todos os casos em que a empresa realiza a produção de um produto completo, possa realizar somente algumas atividades do processo como parte de uma encomenda de montagem. A recíproca não é necessariamente verdadeira e este supõe-se ser o caso das OEA.

Os dois tipos finais, enunciados por Gereffi, são coincidentes com os processos de Progressão Industrial funcional, no caso da mudança intra-setorial, e de Progressão Industrial intersetorial, o que ele denomina de mudança intersetorial.

\footnotetext{
52 O modelo organizacional que foi denominado OEM (Original Equipment Manufacturer), termo primeiramente introduzido pela indústria automobilística (Fleury, Fleury, Cruz-Moreira et al, 2001).

${ }^{53}$ Usar-se-á a tradução "marcas originais" ou "produtores de marcas originais", para "original" ou "own branded manufacturers" - OBM, pois no Brasil utiliza-se "marcas próprias" como equivalente de "private labels".
} 
Da mesma forma, as empresas que alcançam uma integração e/ou a capacidade de coordenação e controle das funções através de um processo de aprendizagem e de progressão contínuos, ou mesmo outras que não as funções do processo produtivo, terceirizando-as e adquirindo competências no lado da comercialização e gestão logística (talvez o caso mais comum de mudança intersetorial), na verdade, adquiriram as competências características das empresas que atualmente lideram as cadeias globais de agregação de valor, ou seja, os produtores ou comercializadores com marca e os grandes varejistas e brokers internacionais.

A inserção nas cadeias de globais (geralmente associado às Zonas de Processamento para a exportação) é, para Gereffi (2000), um primeiro passo para o processo de modernização das empresas dos países em desenvolvimento. Ingressar nas cadeias de valor globais da indústria do vestuário, na função de montagem de peças de roupas como subcontratadas do tipo OEA, representa, ao mesmo tempo, uma oportunidade para aprender a lidar com os compradores globais e um desafio para ocupar os espaços que a dinâmica das cadeias produtivas oferecem.

De acordo com Gereffi (2000), a produção de pacote completo muda totalmente a relação entre a empresa compradora e o fornecedor subcontratado, que obtém maior autonomia e possibilidades de aprendizado na trajetória de modernização industrial. Uma vantagem é apreender sobre comercialização, logística, design e necessidades do cliente com as cadeias de varejistas e de comercializadores internacionais, o que seria praticamente impossível realizando somente atividades de montagem para produtores com marca ou coordenadores internacionais de produção.

Entre os países em desenvolvimento ou economias emergentes, os Tigres Asiáticos Taiwan, Coréia do Sul, Hong-Kong e Cingapura - são geralmente considerados como arquétipos da evolução competitiva na indústria mundial. De maneira geral, esses países foram capazes de sair rapidamente do estágio inicial de "pura montagem", nas chamadas "assembly plants" ou plantas montadoras. Nesse estágio, os componentes, partes ou 
insumos semi-processados são importados dos países sedes das empresas contratantes (onde serão prioritariamente comercializados) ou de outros países fornecedores pelas empresas contratantes, para serem montados pela força de trabalho local.

As empresas dos Tigres Asiáticos lideradas por empresas japonesas, evoluíram rapidamente a partir das funções de montagem, ou seja, do estágio OEA para o estágio OEM. As empresas subcontratadas tornaram-se competidoras globais em mercados conquistados, em função da criação de competências próprias para a coordenação de cadeias produtivas regionais e depois globais. Nesse processo foram realizados ganhos e investimentos que lhes possibilitaram desenvolver vantagens competitivas em vários elos da cadeia, principalmente no setor de fibras químicas, produtos básicos de vestuário e de moda feminina.

O modelo de assembly plants - OEA, que foi seguido depois no processo de industrialização de muitos países em desenvolvimento tardio e que é conhecido, desde sua implantação, no México, como sistema de Maquilas, tem as suas plantas de montagem em geral localizadas em Zonas Processadoras de Exportação - ZPE's, localizadas próximas a grandes portos. No sistema OEA, as operações são puramente de montagem, principalmente as atividades que utilizam maior MDO e, entre suas principais características, podemos destacar:

- Com freqüência as duas empresas, contratante e subcontratada, são independentes, em alguns poucos casos são matriz e filial;

- A maioria das relações não são de longo prazo e nem contratuais;

- A produção é muito móvel, seguindo a oferta de baixos custos da prestação de serviços;

- Há, geralmente, poucas barreiras à entrada de novos competidores, que principalmente utilizam, para isto, estratégias de custo;

- Geralmente essas atividades requerem MDO pouco capacitadas; 
- Muitas vezes, somente algumas operações de montagem são realizadas nas plantas maquiladoras e os produtos são acabados e embalados nas contratantes dos países centrais;

- A empresa fornece de acordo com as especificações estabelecidas pelos compradores/contratantes;

- As especificações de processo de produção vêm da empresa contratante, que também realiza a inspeção e controle de qualidade, principalmente no início da relação interempresarial;

- O fornecedor não tem controle sobre a distribuição e o produto é vendido com a marca do comprador.

Já no modelo OEM, as empresas começam suas atividades como fornecedoras de serviços mais complexos ou, inclusive, de produtos e pacotes completos (full-package) numa cadeia produtiva, provavelmente com melhores remunerações e relações mais longas. As empresas que se enquadram neste estágio precisam de:

- MDO mais capacitada;

- Habilidades de gestão da produção e da cadeia de fornecimento;

- Controle sobre o processo produtivo e a qualidade dos produtos.

Em ambos os casos, essas condições parecem, a princípio, muito restritivas para uma evolução significativa, principalmente no caso das empresas subcontratadas como OEA. Depois de aprender a entender as preferências de clientes estrangeiros, assim como os critérios e os padrões internacionais de preços, qualidade e entrega, persiste ainda a necessidade de criar capacitação para a coordenação de complexas redes de produção, comércio e finanças, para alcançar novos estágios, sob o risco de ficar para trás ou sair da competição. 
Nos Tigres Asiáticos, as competências adquiridas como OEM foram utilizadas para construir uma vantagem duradoura no desenvolvimento das suas exportações, através da produção para grandes marcas mundiais. Num momento posterior e, baseadas num forte processo de aprendizagem, essas empresas passaram de OEM para ODM, assumindo as atividades de design de produtos. Algumas delas conseguiram avançar, tornando-se OBM e já tem marcas originais firmadas internacionalmente. Isto é notório no caso da automobilística, aparelhos eletrônicos (som e tv) e, mais recentemente, telecomunicações.

Para converter-se em OBM e/ou em Compradores Globais (Global Buyers - GB), as principais empresas asiáticas, além de adquirir as competências técnicas, tecnológicas e de gestão necessárias para coordenar a produção internacional, e também conseguir criar e consolidar marcas regionais asiáticas, têm jogado pesado para comprar intangíveis agregadores de valor, difíceis de se construir nos mercados centrais e dinâmicos, porém tradicionais como o americano e o europeu. Exemplo desses ativos agregadores de valor são os nomes de marcas famosas, como foi o caso de redes de varejo na Europa e marcas como Pringle, Tommy Hilfiger (Kaplinsly et Morris, 2001) e Donna Karan NY, nos Estados Unidos.

Entre as competências que as empresas no estágio ODM devem possuir, estão:

- A capacidade de criar e eventualmente produzir produtos com design original;

- Competências tecnológicas para a seleção de insumos e processos, permitindo modificá-los para gerar, como resultado final, um produto inovador;

- Habilidade de realizar parcerias de médio e longo prazos, coordenar e barganhar a realização dos componentes com os fornecedores que tenham a capacidade tecnológica para tal;

- Competências tecnológicas que extrapolem aquelas da produção e gestão administrativa, indo até a utilização de ferramentas, equipamentos e software de $\mathrm{CAD} / \mathrm{CAM}$ como instrumentos para o design; 
- Entendimento das tendências do mercado, dos desejos do cliente e consumidor final, assim como capacidade de inovação para atendê-las e superá-las.

As OBM têm seu maior valor agregado em sua marca da seguinte forma:

- A produção torna-se uma competência que pode ser adquirida;

- Nas competências das ODM, sendo a inovação em design um dos maiores ativos.

Neste sentido, também deve-se considerar como uma posição muito importante aquela das empresas líderes, mais vinculadas à distribuição, ao comércio e ao marketing, os brokers/coordenadores de cadeias de suprimento e as empresas líderes do varejo e varejo de marcas, e não somente as vinculadas à produção. O que se justifica pelo comprovado poder de barganha destas empresas nas cadeias dirigidas pelo mercado, incluindo-os como Global Buyers - GB. Algumas características principais dos Compradores Globais - GB são: a distribuição e logística, a coordenação dos fornecedores e a capacidade de obter valor agregado e lucro a partir da marca.

Toda essa argumentação do conceito e as definições da modernização sugerem uma seqüência definida para as posições alcançadas nas cadeias, de acordo com a tipologia de Modernização Industrial, a qual é mostrada na figura 3.4:

Figura 3.4 - Trajetórias de Modernização Industrial das empresas dos Tigres Asiáticos

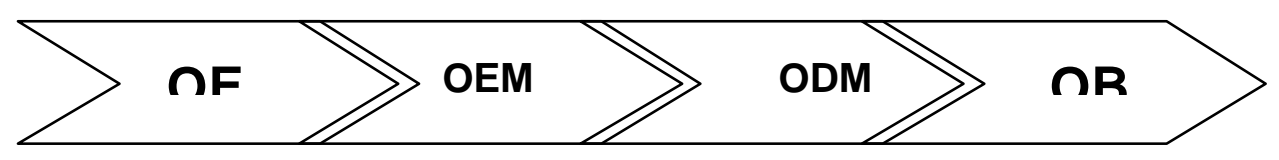




\subsubsection{Progressão Industrial e Modernização Industrial, proposições de compatibilização de Kaplinsky et Morris}

Kaplinsky et Morris (2001) apontam que a sequiência em que esses estágios de Progressão Industrial foram apresentados, coincide com as funções executadas pelas empresas ou posições ocupadas nas cadeias produtivas e pela tipologia de Modernização Industrial, apresentada por Gereffi (2000).

Estes autores destacam que as trajetórias das empresas dos NICs Asiáticos e dos países da ASEAN, como propostas por Gereffi (2000), sugerem uma seqüência hierárquica de estágios de Modernização Industrial, sendo coincidente com a seqüência de tipos de Progressão Industrial (Humphrey et Schmitz (2000), Kaplinsky et Morris (2001) que as empresas podem alcançar. Esta comparação se resume na figura 3.5, extraída de Kaplinsky et Morris (2001).

Fig. 3.5 - Comparação entre Trajetórias de Progressão Industrial e estágios de Modernização Industrial das empresas dos países de industrialização recente

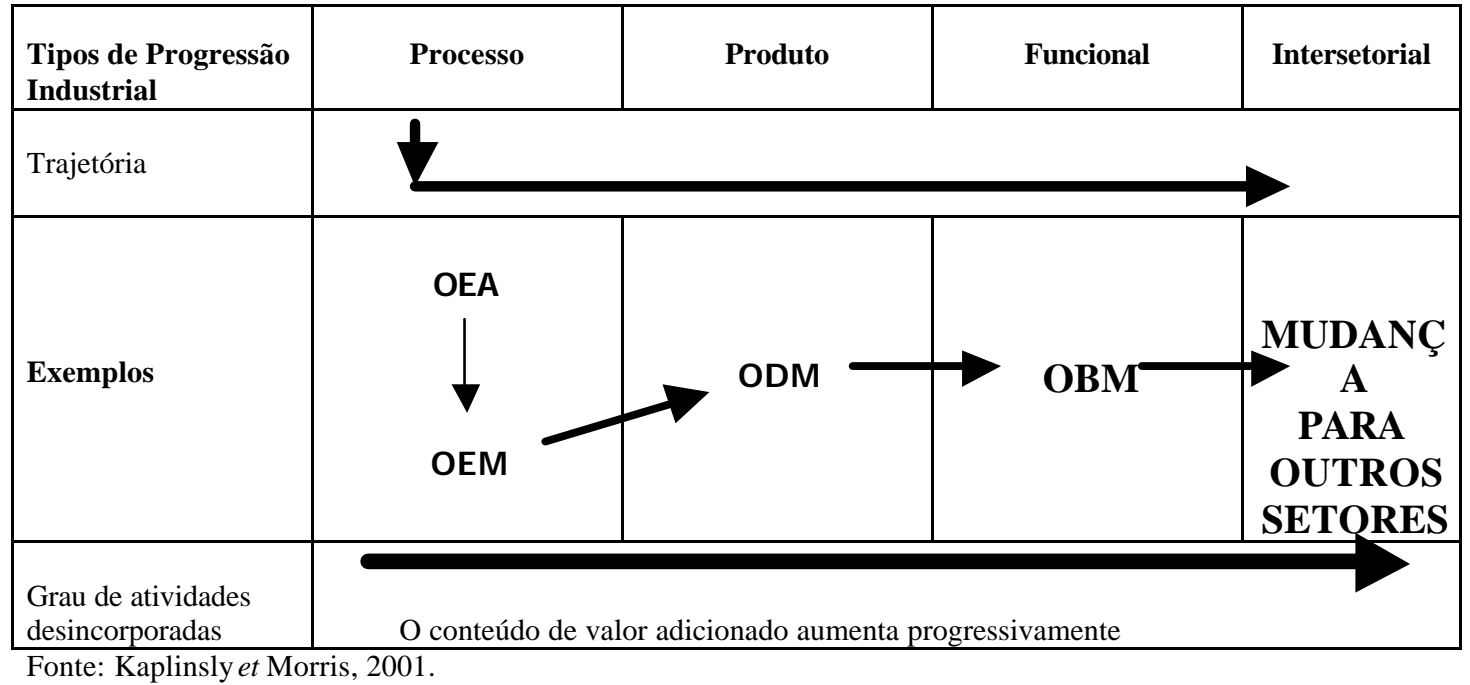




\subsubsection{Uma avaliação crítica da capacidade dos modelos apresentados}

Ambos os modelos são bastante similares e complementares, porém nos parece que não captam a gama completa de relações interempresarias e as trajetórias realizadas pelas empresas na procura da Progressão Industrial nas cadeias produtivas globais.

Considerando que nem todas as empresas seguiram a mesma trajetória, e que o próprio Gereffi (2000) admite que podem-se produzir retrocessos e variações nas seqüências, especialmente naquelas formas mais avançadas da modernização industrial; os modelos apresentados acima são, então, limitados e merecem uma revisão. Por isso, apresenta-se, a seguir, uma avaliação dos modelos descritos acima que constitui o ponto inicial de nossa análise.

Para melhor aprofundar e ilustrar esta "trajetória", estudar-se-á o caso da indústria do vestuário nas experiências recentes, considerando estes estágios como "posições" que podem ser ocupadas pelas empresas participantes das cadeias produtivas e que podem ser atingidas por outros caminhos ou trajetórias diversas. Através de um processo de mudança de posição, as posições podem ser intermediárias ou transitórias, realizando atividades características de dois estágios como, por exemplo, OBM e OEM, simultaneamente.

Assim, a figura 3.6 sintetiza o que consideraremos como Posições de Modernização Industrial que as empresas podem alcançar, e as funções características das mesmas nas respectivas posições. 
Figura 3.6 - $\quad$ Atividades características das empresas nas diferentes posições da Tipologia de Modernização Industrial

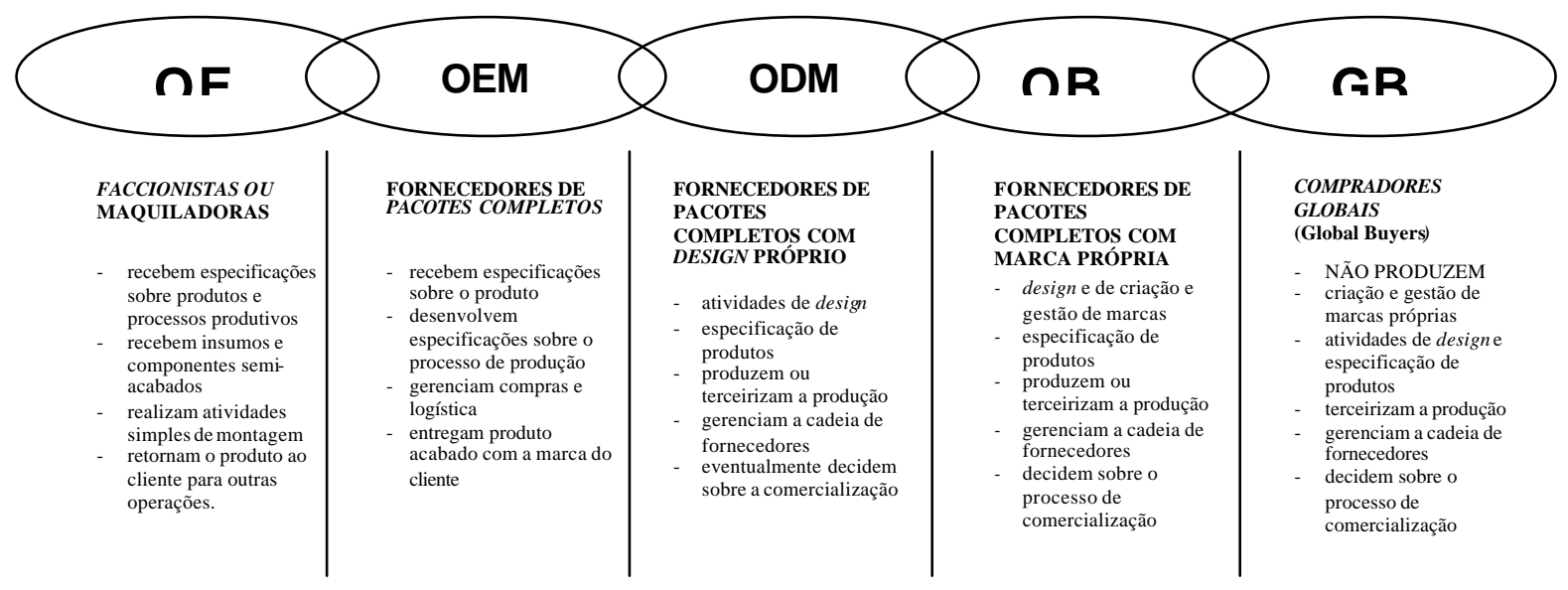

Fonte: Elaboração própria.

Deve-se, ainda, considerar que há empresas que se mantiveram especializadas em determinadas funções do processo produtivo ou em componentes específicos, focalizando ainda mais o seu campo de atividades. De certa forma, esses tipos de empresas são prestadoras de serviços e poderão encontrar-se em posição de subordinação nas cadeias produtivas, cuja governance é exercida pelos tipos de empresas líderes analisadas (produtores de marcas, comercializadores com marca e grandes varejistas). No entanto, estas empresas podem ter certo grau de poder de barganha, dependendo da sua especialidade, domínio tecnológico, escalas de produção e capacidade de inovação ${ }^{54}$.

\footnotetext{
${ }^{54}$ Indústrias correlatas fornecedoras de equipamentos ou serviços são consideradas importantes, suas capacidades de interação na cadeia produtiva podem influenciar fortemente a eficiência coletiva. Tal é o caso das indústrias provedoras de máquinas e equipamentos em quase todos os setores industriais. Muitas vezes, o avanço tecnológico se canaliza através delas.
} 
A seguir, a figura 3.7 mostra, de forma geral, uma síntese do posicionamento e nacionalidade de empresas nas cadeias de formação de valor da indústria de vestuário, havendo exceções para quase todos as categorias.

Fig: 3.7 - Posicionamento de empresas de países selecionados em algumas cadeias de formação de valor típicas da indústria do vestuário

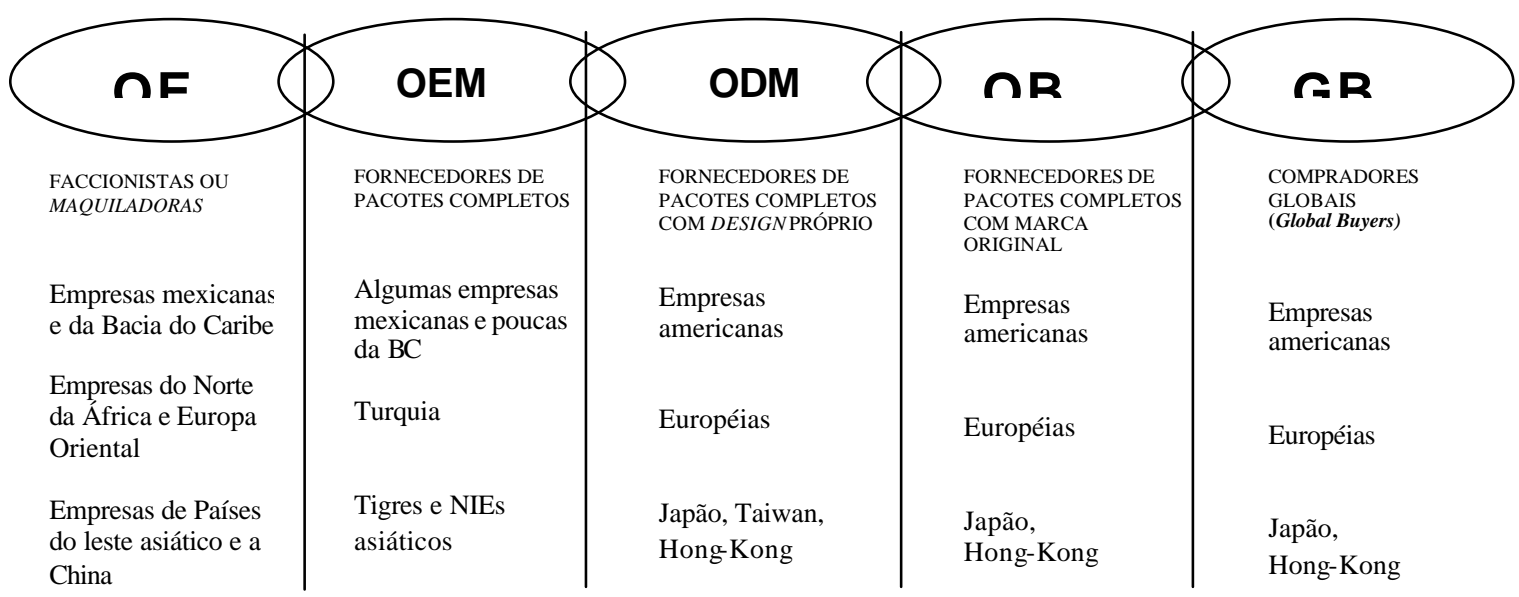

Fonte: Elaboração própria.

A figura 3.7 apresenta uma distribuição simplificada das operações e investimentos. Há que lembrar que empresas americanas, e posteriormente as empresas dos países asiáticos, possuem investimentos na maioria das regiões, especialmente no México e na região da Iniciativa para os Países da Bacia do Caribe - IBC, as empresas européias também têm investimentos nas áreas de influência onde lideram redes de fornecimento próprias. Estes investimentos podem ser "diretos" na forma de filiais ou jointventures, e suas operações geralmente limitam-se a OEA e OEM.

Essas cadeias produtivas são típicas daquelas em que as empresas hondurenhas estão inseridas. Já no Brasil, os investimentos estrangeiros são principalmente direcionados para atender o mercado interno. Ambos os casos serão analisados mais adiante. 
Ademais, não se pode esquecer que, apesar da preeminência das grandes redes de varejo e comercializadores detentores de marcas famosas, há ainda uma considerável produção de vestuário nos países centrais, nas grandes metrópoles, que são centros culturais e de consumo diversificado ${ }^{55}$.

As trajetórias relatadas cobrem o leque das cadeias e empresas que foram mais estudadas para a consolidação do modelo de GCC, fundamentado fortemente na Indústrias Têxtil e de Vestuário, automóveis e eletroeletrônicos. A partir daí, podem-se inferir os padrões a que se chega nesta análise.

Apesar das funções similares das empresas líderes dos países industrializados e dos de recente industrialização, e de competir lado a lado pelos mercados globais e regionais, não se pode esquecer que as primeiras alcançaram esses estágios em trajetórias centenárias e, embora países como o Japão tenham empresas e trajetórias mais longas que as dos países do sul e sudeste asiático, bem como os países da Bacia do Caribe, internamente as configurações atuais das empresas e das estruturas interempresarial das cadeias de valor em que se inserem, são muito diferentes das trajetórias que as empresas como a Levis's passaram.

As trajetórias das empresas européias e americanas são diferentes das recentes trajetórias das empresas da Ásia e do Caribe. No caso das primeiras, a transformação se deu, primeiro, num contexto nacional, e as que saíram para o mercado exterior, saíram

\footnotetext{
${ }^{55}$ Palpaquer (2002) mostra que as duas tendências acontecem em New York; por um lado situam-se nesta cidade as matrizes de algumas das empresas que lideram as cadeias globais de agregação de valor como, as descritas acima e, ao mesmo tempo, há uma grande produção de roupas de moda de alto padrão que precisa de rápida resposta aos caprichos do mercado e MDO especializada. O Estado de New York ocupava, em 2000, em torno de 73.200 trabalhadores na indústria, dos quais $83 \%$ na cidade de New York. Este contingente de trabalhadores é formado por imigrantes legais e ilegais procedentes de Ásia e da América latina, que paulatinamente substituem precariamente aos judeus e italianos que formaram o Distrito das Roupas (Garment District).
}

Segundo a autora, a cidade de Los Angeles, porta de entrada de imigrantes asiáticos, que conta com uma grande população "chicana" e de outros imigrantes da América Latina, representa a segunda concentração da indústria de roupas femininas nos Estados Unidos, a cidade ocupa $70 \%$ das 90.000 pessoas que trabalham neste setor, no estado da Califórnia. Bonacich et Appelbaum (1994) e Bonacich (2002) alertam para a reinsurgência das sweatshops, pela precarização da abundante MDO imigrante. 
primeiro como exportadoras e depois como investidoras multinacionais, posteriormente transnacionais e, finalmente, empresas globais, atuando quase sempre como líderes e agentes promotores da transformação, menos do que receptores das mudanças ou agentes reativos àquelas por elas provocadas.

Por isso, é importante diferenciar as trajetórias das empresas líderes da Europa e dos Estados Unidos - antes do processo de globalização ocorrido - e as dos países menos industrializados cujas trajetórias são inerentes a ele, sintetizadas nas figuras 3.8 e 3.9, a seguir.

Fig.3.8 - Posições na tipologia de Modernização Industrial das empresas dos países desenvolvidos, líderes nas CPTV

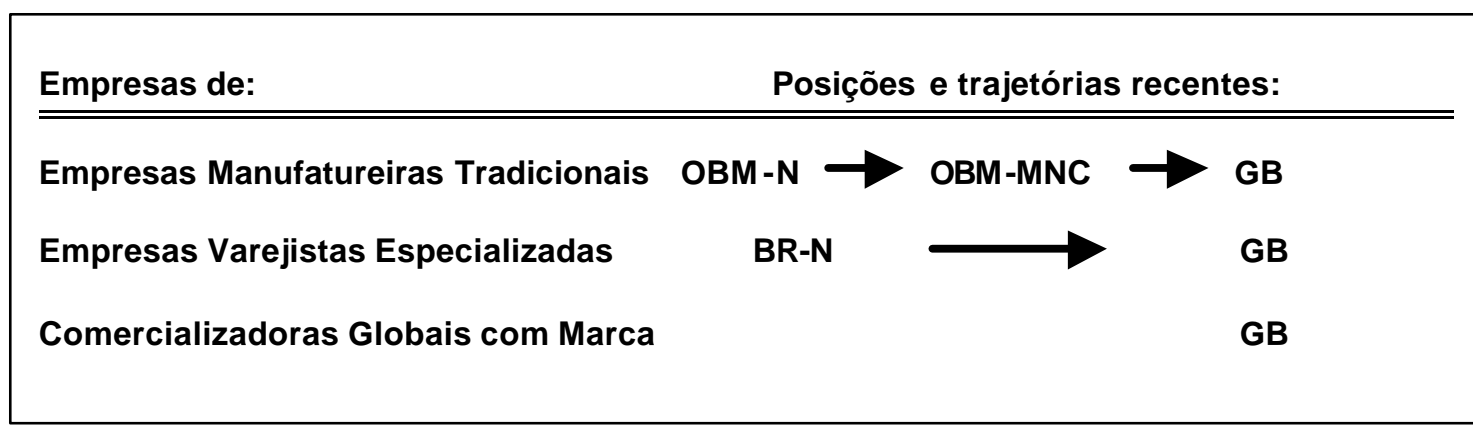

OBM-N: $O B M$ Nacionais

OBM-MNC: $O B M$ Multinacionais

GB: Global Buyers

B R-N: Brandnamed Retailers Nacionais

Fig. 3.9 - Trajetórias de Modernização Industrial das empresas dos países de industrialização recente; posições alcançadas e perspectivas de acordo com países ou regiões.

Empresas de: Trajetórias:

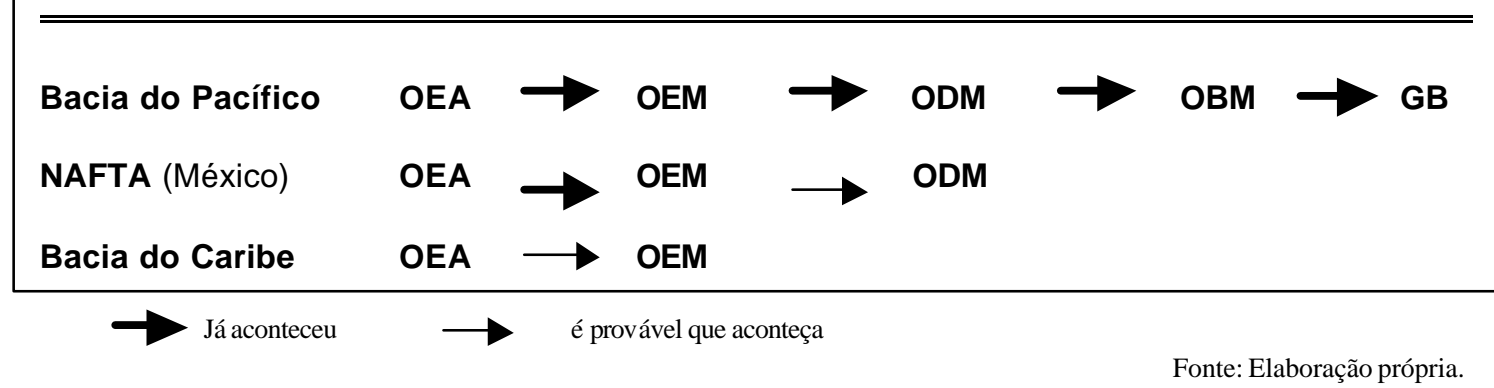


A linearidade deste processo é questionada a partir da análise de trajetórias de empresas ícones freqüentemente citadas na literatura, utilizando para isto o esquema proposto por Kaplinsky et Morris (2001), apresentado no item 3.3.4.

Analisam-se, primeiro, as trajetórias das empresas dos países desenvolvidos que ocupam as posições de liderança nas Cadeias Produtivas Têxtil-Vestuário - CPTV e no comércio global, para depois apresentar as trajetórias e alcances das empresas seguidoras dos países em processo de industrialização.

Este esquema (Kaplinsky et Morris, 2001) carrega a mesma carência da tipologia de Modernização Industrial, que não inclui os Compradores Globais. Como no item anterior, é necessário adicioná-los. As empresas líderes das BDCs estarão representadas por duas categorias de Compradores Globais - GB: (1) as trading companies ou brokers / coordenadores de cadeias de suprimento, que não têm marca original e funcionam como fornecedores internacionais sem realizar a produção, incluindo-se também entre as GB as empresas líderes do varejo de marcas especializadas e do grande varejo (grandes lojas de departamentos multimarcas, lojas de descontos e hipermercados) e (2) as comercializadoras globais com marca que não são produtores. Os produtores com marca já estão incluídos na posição OBM, embora, na maioria dos casos, estes estejam terceirizando grande parte de sua produção. Apresentam-se, a seguir, alguns casos que ilustram e testam o modelo. 


\subsubsection{Trajetórias das empresas líderes dos países desenvolvidos nas Cadeias Produtivas Têxtil-Vestuário - CPTV globais}

\subsection{Trajetória das empresas Produtoras com Marca}

Empresas americanas ou européias iniciaram-se como produtores ou comerciantes de produtos têxteis ou de vestuário, alguns com produtos padrão de consumo de massas, outros como produtores de alta costura com produções locais e passando por diversas transformações no nível da produção, capital, nichos e formas de atuação.

Algumas têm historias centenárias, caso da Levi's, que cresceu internacionalmente como multinacional. Normalmente, as empresas estadunidenses proporcionavam os tecidos e insumos e trasladaram suas operações de costura a empresas no exterior.

Outras mais novas, como a Benetton, desenvolveram suas cadeias de fornecedores ao mesmo tempo em que a estrutura de distritos industriais e as pequenas e médias empresas tinham seu auge na Terceira Itália.

Ambos os casos são considerados aqui a partir de seu papel como líderes de CPTV globais, quando a distribuição internacional do trabalho e a competição global conformam as novas estruturas inter empresariais.

A acumulação de capital e conhecimento destas empresas permitem-lhes o investimento e a inovação no uso de tecnologias avançadas, como Electronic Data Interchange - EDI, para o controle da cadeia de fornecedores e para a análise das informações do mercado, que lhes possibilita a eficácia de extensas campanhas de marketing "glocais". Além de serem usuárias de tecnologias geradas em outros setores, como as indústrias químicas produtoras de fibras e insumos para o acabamento, na produção de máquinas especializadas, da Tecnologia da Informação - TI e das tecnologias de gestão do varejo, elas conseguem investir em aplicações tecnológicas para a mass customisation, como os 
Body Scanners e as nanotecnologias, que permitem a fabricação de fibras e tecidos inteligentes, revolucionando a logística e o funcionamento da cadeia de fornecimento nestas indústrias.

Embora não mudem totalmente de setor, algumas firmas diversificam seus investimentos em áreas de produtos complementares, como equipamento esportivo, ou investem conjuntamente em tecnologias de informação para a realização de $e$-business.

Ao longo da cadeia podem citar-se vários nomes de reconhecimento mundial: as produtoras de fibra como a Dupont e a Rhodia, cujo valor de marca é trasladado aos produtos finais; empresas com marcas globais, como as americanas Levi Strauss \& Co., VF Corporation (Wrangler) e Phillips Van Heusen, e européias como Armani, Benetton e a mais recente, a espanhola Zara.

A figura 3.10, a seguir, tenta representar, simplificadamente, a Progressão Industrial e as posições de Modernização Industrial das empresas produtoras com marca.

Fig.3.10 -

Trajetória das empresas globais Produtoras com Marca

\begin{tabular}{|l|l|l|l|l|}
\hline $\begin{array}{l}\text { Tipos de } \\
\text { Progressão } \\
\text { Industrial }\end{array}$ & Processo & Produto & Funcional & Intersetorial \\
\hline $\begin{array}{l}\text { Estágios de } \\
\text { Modernização } \\
\begin{array}{l}\text { Industrial e } \\
\text { trajetória }\end{array}\end{array}$ & ODM & OBM & $\begin{array}{c}\text { MUDANDÇA } \\
\text { PARA } \\
\text { OUTROS } \\
\text { SETORES }\end{array}$ \\
\hline
\end{tabular}

Fonte: Elaboração Própria.

Em termos de Progressão Industrial, estas empresa já entraram no processo de globalização com competências de produção e design, e com nomes de marcas famosas, A progressão mais comum é a funcional e as competências adquiridas foram as de 
marketing e de gestão de fornecedores. A progressão intersetorial obtém-se, normalmente, por joint ventures ou por aquisição de empresas.

As firmas mais novas, como a Benetton e a Zara, desde o início tiveram sua força no design. No caso da Benetton, a capacidade de gestão de fornecedores e sua habilidade usando EDI ajudaram a competir e firmar seu nome. A Zara, que também tem seu forte no design, inicialmente realizava sua própria produção. Com o seu sucesso e crescimento teve, recentemente, que começar a desenvolver uma cadeia externa de fornecedores.

Assim, a evolução típica deste tipo de empresas líderes inicia-se na posição ODM ou OBM, chegando até a posição de GB, e eventualmente alguns diversificam seus investimentos para outras atividades, com freqüência relacionadas ao negócio principal.

\subsection{Trajetória das empresas Varejistas}

Algumas delas iniciaram-se como revendedores exclusivos ou franqueados de produtores de marcas, ou como lojas de departamentos multimarcas. Com a concorrência dos asiáticos ou a crescente demanda de qualidade, design, preço e a especialização de nichos de mercado requerida pelos consumidores, algumas deixaram de lado os produtores de marca e criaram as suas exclusivas redes de varejo com produtos de alta qualidade e diversidade a melhores preços, ou como no caso das lojas de departamentos multimarcas, se aliaram inicialmente aos comercializadores de marcas, mesmo que, ao final, a maioria tenha também criado suas marcas originais. Para isto, tiveram que recorrer ao fornecimento de empresas estrangeiras, muitas vezes tendo que desenvolver seus fornecedores.

As competências desenvolvidas estão relacionadas, principalmente, à capacidade de gestão de fornecedores, logística e distribuição, assim como às competências de marketing. As empresas que optaram pelos nichos de mercado de maior poder aquisitivo 
tiveram que investir muito em competências de design. Algumas das empresas mantém diferentes marcas/linhas de produtos para diferentes nichos de mercados, liderando cadeias mais complexas, às vezes dirigidas como empreendimentos separados (como é o caso de The GAP, Banana Republic e Old Navy).

A figura 3.11 mostra a evolução destes tipo de empresas em relação ao modelo. Quanto às posições de Modernização Industrial, as empresas passam de simples varejistas que distribuíam os produtos das OBM a varejistas de marca e Compradores Globais - GB, simultaneamente. $\mathrm{O}$ aprendizado ou execução de funções de gestão de marcas e design não os converte em ODM ou OBM por que estas empresas geralmente não produzem.

Fig. 3.11 - Trajetória das empresas globais Varejistas com Marca

\begin{tabular}{|c|c|c|c|c|}
\hline $\begin{array}{l}\text { Tipos de Progressão } \\
\text { Industrial }\end{array}$ & Processo & Produto & Funcional & Intersetorial \\
\hline $\begin{array}{l}\text { Estágios de } \\
\text { Modernização } \\
\text { Industrial e } \\
\text { trajetória }\end{array}$ & & & $\begin{array}{c}\text { Varejistas especializados ou } \\
\text { multimarcas de produtos das } \\
\text { GB } \\
\text { (Varejistas com Marca/ } \\
\text { Compradores Globais) }\end{array}$ & \\
\hline
\end{tabular}

Já em relação à tipologia de Progressão Industrial, o avanço é mais claro e vai além da geografia do fornecimento. Em ambos os casos, considera-se a progressão do tipo funcional, fundamentado no conhecimento de mercado e, principalmente, na aquisição de competências de gestão de marca, na negociação com fornecedores, e no design.

Similares trajetórias à de The Gap possuem The Limited e Victoria's Secret no caso de varejistas de marca, e no caso das redes de lojas de departamento e cadeias de desconto, 
JC Penney, Wal-Mart, Sears, entre outros; na Europa, a holandesa C\&A e a inglesa Marks \& Spencer são bons exemplos (Dickerson 1999, Gereffi, 1999).

\subsection{Trajetória das empresas Comercializadoras com Marca}

As empresas comercializadoras com marca, além de já nascerem globais, nunca tiveram fábricas e a maior parte de seus insumos, desde o início, foram adquiridos no exterior.

Sua efetividade fundamenta-se no valor de sua marca e na gestão da cadeia de fornecedores e serviços de logística, adotando padrões de certificação de qualidade com os fornecedores e de padrões de desempenho com os varejistas que comercializam seus produtos.

O design e a gestão da marca (através de audaciosas campanhas globais de marketing) são as atividades que agregam maior valor, por isso atividades de Pesquisa e Desenvolvimento - P\&D e desenvolvimento de produtos têm ganhado espaço entre as core competences destas empresas, assim como os fornecedores que têm capacidades para, conjuntamente com a empresa, detentora da marca, desenvolver novos e inovadores produtos e flexibilidade suficientes para dar uma resposta rápida às exigências do mercado, tornando-se fornecedores de primeiro nível. No segundo nível estão aqueles que têm escalas de produção para a produção de grandes volumes e preços competitivos. No terceiro nível, produtores evertuais geralmente são coordenados pelos fornecedores com maior capacidade e confiabilidade, e executam produções com menores requerimentos e menor remuneração.

Ao nível de posições de Modernização Industrial, estas empresas já nasceram no estágio das atividades mais avançadas nas cadeias produtivas, ajudando a revolucionar a estrutura pré-estabelecida dos grandes produtores e varejistas. 
As atividades em que se envolvem estas empresas, que ao contrário das produtoras de marca iniciaram-se nos elos mais próximos ao mercado, têm tido que agregar competências mais próximas da produção, como as de $P \& D$ e desenvolvimento da cadeia de fornecedores descrita acima, constituindo uma progressão funcional. Embora as atividades envolvam competências no nível de produto e processos, isto não significa um downgrading ${ }^{56}$, pois o que acontece é uma integração maior de competências ao longo da cadeia produtiva. O ícone deste tipo de empresas é a Nike, cujo caso tem sido bem documentado por autores como Korzenievicks (1994).

Outras empresas menos inovadoras no desenvolvimento de produtos, porém cuidadosas com o prestígio de suas marcas, têm sobrevivido outorgando licenças para produtores e/ou comercializadores, sem envolverem-se diretamente com a produção ou mesmo com a distribuição, auferindo lucros na base de royalties, como é o caso da Polo Ralph Laurent, que também tem investido em outros campos mais ligados ao marketing, à mídia e comunicação relacionados às novas TI (Smith, 2001). A figura 3.12 mostra a progressão em direção ao produto e a novos investimentos.

Fig. 3.12 - Trajetória das empresas globais Comercializadoras com Marca

\begin{tabular}{|c|c|c|c|c|}
\hline $\begin{array}{l}\text { Tipos de Progressão } \\
\text { Industrial }\end{array}$ & Processo & Produto & Funcional & Intersetorial \\
\hline $\begin{array}{l}\text { Estágios de } \\
\text { Modernização } \\
\text { Industrial e } \\
\text { trajetória }\end{array}$ & & & GB & $\rightarrow$ \\
\hline
\end{tabular}

Fonte: Elaboração Própria.

\footnotetext{
${ }^{56}$ Conceito apresentado por Rabelotti (2001), que relata casos similares para a indústria de calçados italiana. Este tipo đe "crescimento" econômico pelo ingresso nas cadeias internacionais representa um downgrading funcional, tanto no design, controle da produção e nas atividades de gestão de cadeia de fornecedores e de comercialização.
} 
LA Gear, Reebok (Korzerniewickz, 1994), Liz Clairbone, Dona Karan, Tommy Hilfiger, Nautica (Gereffi, 2000) Gucci e Abercrombie \& Fitch (Smith, 2001), percorrem similares trajetórias, que podem ser enquadradas como de compradores globais - GB.

\subsubsection{Trajetórias das empresas dos países de recente industrialização na Ásia e no Caribe}

O primeiro grande traslado de atividades produtivas na CPTV realizou-se para os NICs asiáticos, precedidos pelo Japão, impulsionado pelos varejistas e comercializadores de marcas dos Estados Unidos e da Europa. Foi também nestes países que as primeiras barreiras protecionistas foram impostas, culminando na assinatura do Acordo Multifibras - AMF. As empresas asiáticas já tinham apreendido o suficiente para ultrapassar as novas barreiras. Elas aprenderam a fabricar produtos mais

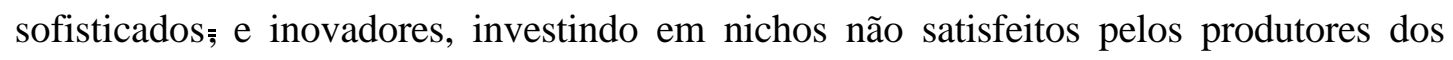
países centrais, tornando-se ainda mais lucrativas do que os produtos protegidos.

Como reação a estas pressões competitivas, os produtores dos países centrais, suportados por marcos legais de seus governos - preferências tarifarias e regimes de maquilas começaram a trasladar atividades produtivas para países mais próximos menos desenvolvidos .

A seguir, analisar-se-ão as trajetórias de Modernização Industrial e de Progressão Industrial seguidas por empresas asiáticas e da região do Caribe para competir no mercado global.

\subsection{Trajetórias das empresas asiáticas}

Apesar da grande diversidade de empresas existentes hoje nos países asiáticos, o crescimento do mercado e a expansão da produção a países dentro da região, como ilustrado pelo modelo de "the flying geese", trata-se aqui de sintetizar as trajetórias mais 
completas das empresas asiáticas, que alcançaram os estágios de OBM e de GB nas CPTV globais.

Baseadas no forte processo de aprendizagem, algumas das empresas passaram de fornecedoras internacionais OEM a fornecedoras "full-package" ODM, tornando-se depois OBM regionais. Desenvolveram extensas redes de comercialização na Ásia ao tempo que continuavam a fornecer para as redes de varejo ocidentais. A cadeia de roupas femininas Episode, controlada pelo Hong-Kong's Fang Brothers Group, um dos maiores fornecedores OEM para a Liz Clairbone nos anos 70 e 80, com lojas em 26 países, das quais apenas um terço na Ásia, é um claro exemplo desta evolução (Gereffi, 1999).

Outro exemplo asiático é a Giordano, marca de roupas mais famosa de Hong-Kong. A partir de uma base de fábricas de restuário, desenvolveu sua rede de comercialização: 200 lojas em Hong-Kong e China, e mais 300 lojas de varejo espalhadas pelo sul da Ásia e Coréia. A Giordano, recentemente, entrou nos Estados Unidos através da aquisição das marcas Tommy Hilfiger e Liz Clayborne.

Estas duas empresas exemplificam os maiores avanços em Progressão Industrial e as trajetórias contemporâneas mais completas em termos de Modernização Industrial dentro de um mesmo setor, as quais são sintetizadas na fig. 3.13.

Fig. $3.13-$ Trajetória das empresas dos NICs Asiáticos

\begin{tabular}{|l|c|c|c|c|}
\hline $\begin{array}{l}\text { Tipos de Progressão } \\
\text { Industrial }\end{array}$ & Processo & Produto & Funcional & Intersetorial \\
\hline $\begin{array}{l}\text { Estágios de } \\
\text { Modernização } \\
\begin{array}{l}\text { Industrial e } \\
\text { trajetória }\end{array}\end{array} \quad$ OEA & \multicolumn{1}{|c|}{ ODM } & GBM & \\
\hline
\end{tabular}

Fonte: Elaboração Própria 


\subsection{Trajetórias das empresas Mexicanas e de países da Bacia do Caribe}

O México e os países da América Central e o Caribe têm acirrado a competição pelo mercado estadunidense de vestuário. Os países tentam obter a paridade com o NAFTA, que junto com a grande desvalorização do Peso Mexicano, deu a este país uma grande vantagem ante os países do Caribe e da América Central. Por sua vez, as empresas do países da IBC têm aproveitado, tanto quanto possível, as paulatinas concessões de preferências dentro desse marco legal. A competição com o México tem sido menos desastrosa do que se esperava, e as exportações destes países para os Estados Unidos têm crescido, ainda que menos do que se o NAFTA não existisse ou se a paridade fosse total (Buitelaar et Rodriguez, 2000).

Na verdade, o que as estatísticas mostram é que parte do ganho do México e os Países da IBC nas exportações para os Estados Unidos deve-se ao traslado de operações e à subcontratação da Ásia para a região. Ao longo prazo, a disputa atual com o México significa, para os países da IBC, a oportunidade de consolidar alianças interempresarial e nichos de mercado, antes que a China entre por completo na disputa por este mercado (e todos os outros mercados centrais). Nesse sentido, o inimigo é comum para todos os produtores, tanto nos Estados Unidos, como no México e na Bacia do Caribe. Do outro lado estão os varejistas, cujo fornecimento deve vir de onde for mais competitivo (isto é, mais barato).

A proximidade geográfica e as vantagens do NAFTA teriam permitido às empresas mexicanas e às filiais americanas, terem avanços nos estágios de Progressão Industrial e nas posições de Modernização Industrial, mais rapidamente do que os países da IBC.

Gereffi (1999, 2000 a, 2000 b), Gereffi et Bair (2002), Vangstrup (2002), descrevem estratégias e trajetórias de empresas filiais americanas e de empresas locais que se integraram às cadeias de exportação em todos os elos das CPTV. 
Gereffi e Bair (2002) apresentam uma panorâmica de todos os tipos de empresas atuando no México nas cadeias integradas a empresa líderes estadunidenses, entre elas empresas produtoras de fibras sintéticas (Dupont), tecelagens (Burlintong Industries, Cone Mills, Guilford Mills), produtores de marca (VF Corporation, Sara Lee Corp, Levi Strauss \& Co.) e varejistas (JC Penney) de vestuário estadunidenses. Assim como produtores integrados (Avante Textil e Kaltex) e brokers/intermediários comerciais (Aztex trading Company) mexicanos. Os autores fazem uma análise da Progressão Industrial alcançada pelas maquiladoras mexicanas, e mostram que estas maquilas possuem todas as competências, exceto as de design, marketing e de varejo, que são zelosamente preservadas pelas empresas estadunidenses.

Vangstrup (2002) apresenta, detalhadamente, casos de 3 empresas maquiladoras especializadas em malharia, duas das quais iniciaram-se como empresas OEM locais (Salvatierra e San Miguel El Alto) e uma que foi fundada para atender ao mercado de exportação como maquiladora (Celaya). A figura 3.14 sintetiza a trajetória destas empresas.

Não se sabe nada sobre as capacidades prévias das empresas que atuavam como OEM para o mercado local, em termos de competências de design. Provavelmente estas empresas tinham alguma capacidade de desenvolvimento de produtos (cópia, benchmarking ou engenharia reversa) ou mesmo de design incipiente ou suficientes para agradar o mercado local que atendiam. Neste caso, elas teriam passado de ODM para OEA, dentro da trajetória de posições este seria um retrocesso, pois funções e/ou habilidades perderam-se. Este caso merece análise cuidadosa, já que, apesar de diminuir a gama de atividades/funções/habilidades/competências necessárias para a elaboração dos produtos completos, as exigências de qualidade, prazo, volume e de procedimentos de comércio internacional são maiores, precisando de um intenso aprendizado e especialização. 
Fig. $3.14-$

Trajetória das empresas maquiladoras mexicanas

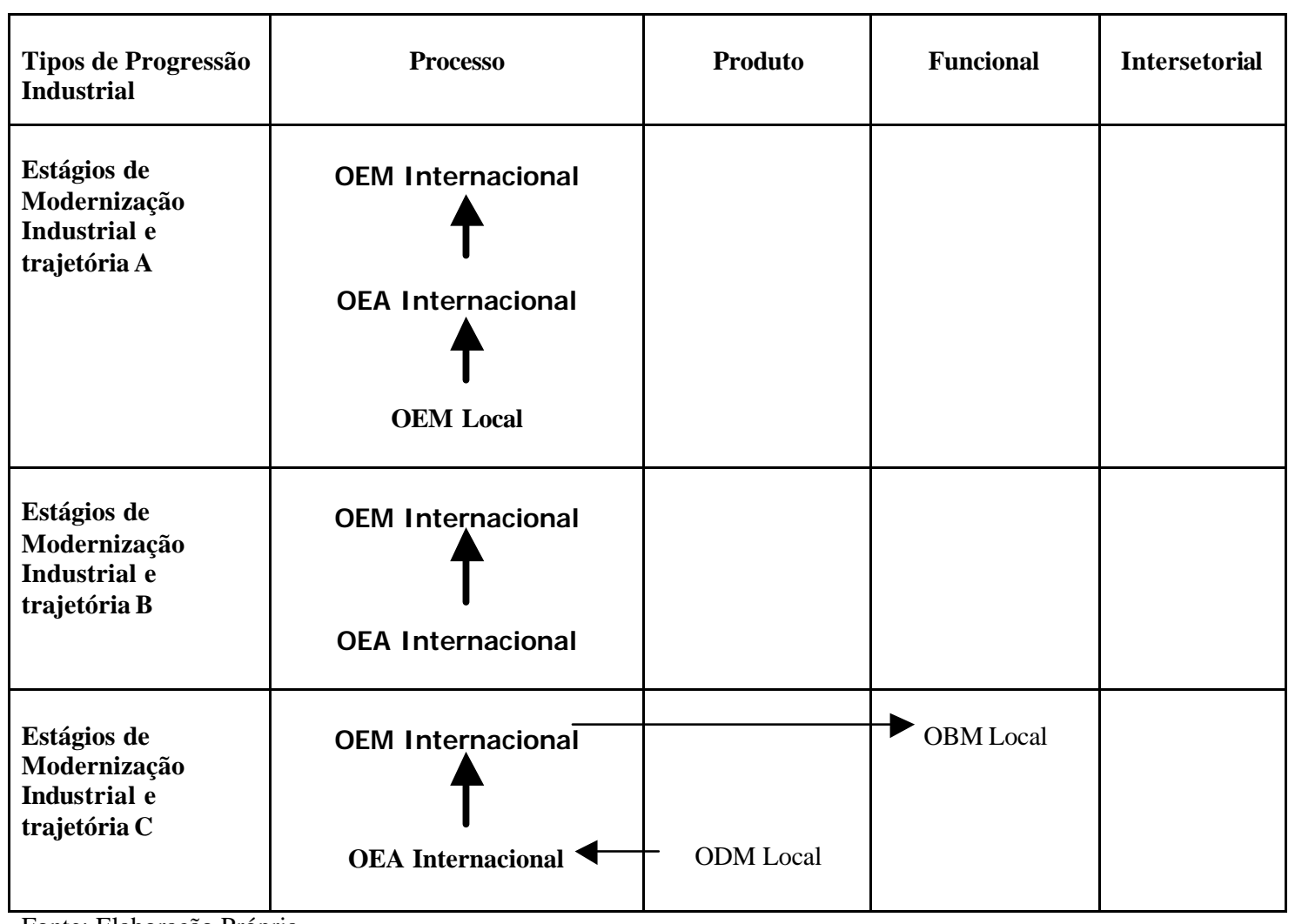

Fonte: Elaboração Própria.

Nas empresas que se iniciaram voltadas para o mercado internacional, as competências no nível de produto e processos de produção foram menores, e foi preciso, desde o início, lidar com os padrões internacionais. A progressão maior é notada quando se passa de OEA para OEM do tipo pacote completo.

A capacidade em gestão, a profissionalização e as oportunidades do mercado exportador fizeram possíveis o crescimento e a consolidação destas empresas. As empresas analisadas por ambos os autores parecem priorizar o mercado estadunidense, embora algumas estejam começando a exportar diretamente para outros países da América Latina. 
As competências desenvolvidas para a exportação possibilitam uma eventual atuação no mercado interno bem como OEM ou, inclusive, como OBM. A capacidade de design não foi mencionada em nenhum dos casos para o mercado interno, e sabe-se que, para o mercado externo, esta é uma competência reservada às empresas estadunidenses líderes das CPTV dirigidas ao mercado estadunidense.

A trajetória $\mathrm{C}$ é a mais completa e provavelmente a menos comum ainda.

No caso das empresas dos países da IBC, com raras exceções, a maioria das exportações de vestuário ainda se realizam sob os regimes 807 e 9802 da maquila, que privilegia os produtos montados a partir de insumos de origem estadunidense.

Apesar das diferentes estratégias de modernização, das diferentes quotas de poder de decisão nas CPTV que são inseridas e da aparente especialização por produtos dos países (Buitelaar, 2000) há, no entanto, alguma homogeneidade nos parâmetros que aqui se analisam. Particularmente, a incapacidade de atingir posições de Modernização Industrial e/ou estágios de Progressão Industrialavançados, de acordo com o modelo.

A maioria da produção ainda é restrita à maquila (montagem), embora sejam realizadas mais atividades do que simples costura, ainda são os insumos estadunidenses que predominam na produção destes países. As empresas de alguns países estão produzindo pacotes completos com tecidos de fora da área e do NAFTA.

Quanto ao poder, Buitelaar (2000) refere-se, principalmente, à habilidade de acesso direto a compradores nos países centrais e a outras capacidades relacionadas, como a comercialização. Destaca-se o caso da Nicarágua, onde as empresas usualmente têm maior diversidade de clientes.

As estratégias de produto mais ou menos complexos determinam a estratégia tecnológica, o que terá conseqüências a longo prazo. O autor destaca o avanço de 
atividades tecnológicas mais complexas em El Salvador, por exemplo, porém não encontramos na literatura nenhum indicativo de que atividades de design, capacidade que é um dos indicadores da Progressão Industrial. A figura 3.15 resume as trajetórias inferidas nas empresas dos países da IBC.

Fig. 3.15-

Trajetória das empresas maquiladoras dos países da IBC

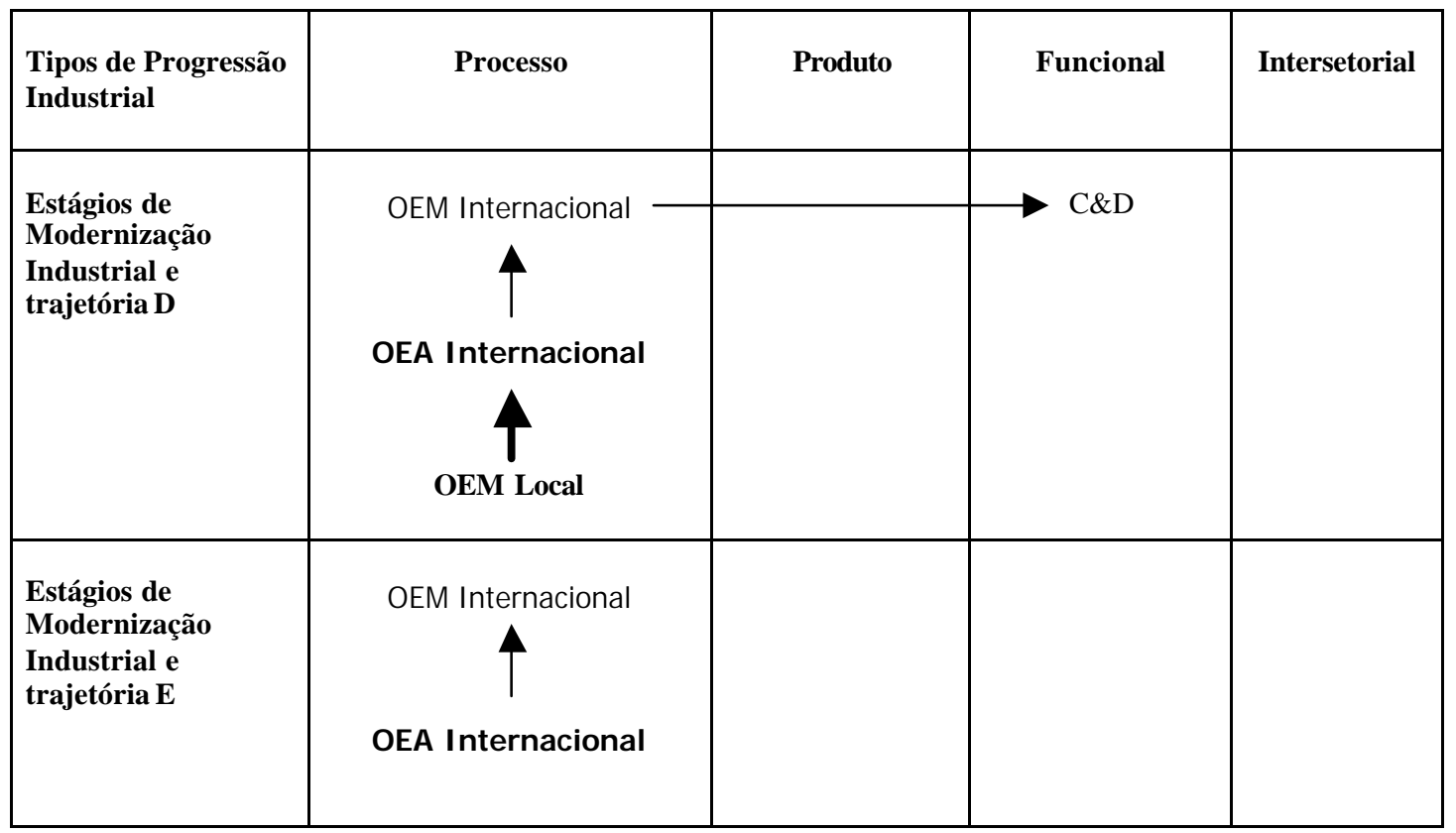

Fonte: Elaboração Própria. $\quad \mathrm{C} \& \mathrm{D}=$ Comercialização e Distribuição

As duas trajetórias principais apresentadas são aquelas da conversão, total ou parcial, de grupos locais OEM ou OBM para OEA e, eventualmente, OEM, de exportação para os Estados Unidos.

Algumas empresas estão avançando na área de comercialização, evitando os intermediários comerciais e colocando os produtos no cliente final. Isto foi destacado por Buitelaar (2000) em relação a empresas da Nicarágua, onde a indústria é mais recente. A obtenção de competências em Comercialização e Distribuição - C\&D próprias, é um exemplo de Progressão Industrial. 


\subsection{A proposição de um novo modelo}

De acordo com os exemplos anteriores, a trajetória das empresas asiáticas sugere que é possível alcançar as posições de Modernização Industrial, mais avançadas e lucrativas, por processos intensos de aprendizado, buscando ocupar ou criar nichos de mercado, inovando em produtos e tecnologia. É possível estruturar e liderar cadeias de agregação de valor a partir de indústrias intensivas em MDO, chegando a ameaçar a hegemonia das empresas dos países industrializados.

As empresas asiáticas que atingiram os estágios de liderança podem ter suas trajetórias sintetizadas nos seguintes estágios:

- A partir dos estágios OEM (full-package), como subcontratadas ou fornecedoras para as empresas dos países industrializados;

- A consolidação de marcas originais em mercados locais e regionais, atuando como produtores, comercializadores e varejistas regionais;

- A aquisição de marcas de renome nos mercados dos países industrializados para atuar como produtores e comercializadores globais.

O crescimento das exportações do México e dos países da Bacia do Caribe para os Estados Unidos mostra a eficácia dos acordos preferenciais (com enormes vantagens para o México) e permitiram-lhes o avanço até os estágios atuais, com considerável participação de mercado, porém ocupando ainda as posições iniciais de modernização e sem muita possibilidade de avanço nos estágios iniciais de Progressão Industrial nas CPTV.

Esses acordos preferenciais são parte das estratégias protecionistas dos Estados Unidos, baseadas em tarifas e quotas, e que provocaram, inclusive, uma perda de participação 
das economias asiáticas e as forçaram a investir na região, o que, ao final, torna-as ainda mais experientes e eficientes nas competições globais.

As limitantes para a competitividade das empresas da América Central, mais do que intrínsecas, são devidas a essas medidas preferenciais e protecionistas, que resultaram na divisão internacional da produção e do consumo, manifestadas nas estruturas hierárquicas das cadeias globais de produção.

A trajetórias apresentadas, assim como as que serão analisadas a seguir são diversas, e as estruturas hierárquicas e as quotas de poder nas cadeias são dinâmicas ao longo do tempo. Também a variável geográfica e o processo de transformação (nputouput) do modelo se modificam como os ambientes institucionais, sendo cada dia mais globais e regidos por acordos internacionais.

No entanto, para apreender é necessário aprofundar nas trajetórias que ajudaram a construir os modelos e constatar que as estratégias, tanto das empresas dos países industrializados, dos NICs asiáticos como dos novos competidores da América Central e Caribe, são diversas. Algumas destas empresas têm, como estratégia, a consolidação de sua posição como fornecedores "full-package" de baixo custo (talvez a mais arriscada), tentando elevar sua produtividade, enquanto outras tentam pular estágios e chegar mais perto do cliente final através de produtos e serviços mais sofisticados, que implicam na aquisição de competências de marketing, distribuição e design.

Portanto, o modelo seria bem mais complexo, representado na fig.3.16 a seguir: 
Fig. 3.16 Trajetórias de Progressão Industrial e Modernização Industrial

\begin{tabular}{|l|c|c|c|c|}
\hline $\begin{array}{l}\text { Tipos de Progressão } \\
\text { Industrial }\end{array}$ & Processo & Produto & Funcional & Intersetorial \\
\hline $\begin{array}{l}\text { Estágios de } \\
\text { Modernização } \\
\text { trajetória D }\end{array}$ & OEA & & ODM &
\end{tabular}

*OBM Inclui Brandnamed Manufacturers e GB = Global Buyers: Brandnamed Marketers, Brandnamend Reatailers \& SupplY Chain Coordinators (Broker/agentes comerciais)

..... Esta mudança pode ser realizada também em outros estágios anteriores aos de OB e GB.

Fonte: Elaboração Própria

\section{5} As perguntas da pesquisa

Com esses pressupostos, se formulam as perguntas da pesquisa:

- São as trajetórias asiáticas de inserção nas cadeias produtivas globais, as únicas possíveis para as empresas dos países menos industrializados alcançarem uma Progressão Industrial, ganhos de poder e competitividade no comércio internacional?

- Quais são os fatores que influenciam a competitividade das empresas nas cadeias produtivas globais?

- Quais as possibilidades para as empresas dos países em desenvolvimento alcançarem posições de liderança nas cadeias produtivas globais?

- Qual a relação entre Cadeias Produtivas Globais, Progressão Industrial e desenvolvimento social e econômico? 


\section{CAPÍTULO 4}

\section{A PESQUISA DE CAMPO - METODOLOGIA}

Este capítulo resume os proedimentos metodológicos seguidos para a realização deste estudo:

\subsection{Análise documental}

Inicialmente realizou-se uma análise documental, por meio de revisão bibliográfica dos estudos de Global Commodity Chains - GCC, cadeias produtivas, cadeias de valor, redes de cooperação, arranjos industrias etc. Os conceitos de Progressão Industrial e as tipologias de Modernização Industrial foram revisadas. Os dois modelos julgaram-se complementares para a construção do referencial teórico do estudo.

As perguntas colocadas no capítulo anterior serão respondidas a partir da análise dos casos das empresas: maquiladoras de roupas de Honduras e de cadeias de produtivas têxtil-vestuário do Brasil.

Informações primárias foram coletadas por meio de entrevistas com executivos de empresas e diretores de associações empresariais, assim como acadêmicos. Por 
solicitação das empresas os nomes das mesmas e dos entrevistados não são citados no texto. A amostra é detalhada neste capítulo.

Dados secundários sobre as indústrias do complexo têxtil-vestuário foram analisados a partir de estudos e dados publicados pelas associações, governo e organismos internacionais, das empresas de ambos países, no nível nacional e da participação no comércio internacional, tentando captar as mais importantes etapas de desenvolvimento e mudanças recentes, assim como os novos fatores de competitividade no mercado internacional.

\section{2 $O$ método da pesquisa de campo em função das perguntas do estudo}

Estudos de casos múltiplos foi a metodologia escolhida para a realização da pesquisa de campo, em função da necessidade de trabalhar com os diversos aspectos que compõem um processo de reestruturação industrial, das relações interempresariais em contextos globais, porém diferenciados.

As razões enumeradas por Yin (1984) e Lazzarini (1995) para que o método de estudo de casos possa ser considerado adequado, do ponto de vista teórico, são pertinentes à análise proposta. Baseando-se nos autores acima citados, os estudos de casos múltiplos devem ser utilizados quando:

- As situações analisadas são contemporâneas, abrangentes e complexas.

- O fenômeno não pode ser estudado fora de seu contexto sem perda de utilidade da pesquisa.

- O foco maior é na compreensão dos fatos e não na sua mensuração.

- Existem necessidade de utilizar-se várias fontes para evidenciar os fatos.

- Não se possui o controle sobre os eventos/comportamentos dos fatos/pessoas envolvidos na pesquisa. 
Ademais, os estudos de casos múltiplos servem para avaliar experiências inseridas em diferentes contextos, o que segundo Lazzarini (1995:21), contribui para tornar a pesquisa mais robusta.

\subsection{Instrumentos da pesquisa}

Entrevistas semi-estruturadas foram realizadas, auxiliadas por questionário guia. Este foi elaborado e validado na pesquisa no Brasil e posteriormente traduzido para o espanhol, tendo algumas perguntas adaptadas ao contexto das maquiladoras hondurenhas. Os dois documentos apresentam-se anexados.

\subsection{Seleção da amostra}

Assim, a amostra objetiva obter evidências para responder a essas questões e validar a tese. Desta forma, os critérios adotados para a definição da amostra foram:

Selecionaram se as cadeias produtivas que apresentassem maior dinamismo em cada país, i.e, que tivessem uma grande repercussão no contexto nacional e internacional, com base na análise documental.

No Brasil, a amostra da pesquisa tentou modelar essas cadeias a partir de empresas líderes segundo o modelo teórico de GCC nos diferentes elos produtivos.

A pesquisa no Brasil foi realizada em 30 empresas, a maioria das quais participantes de cadeias produtivas classificadas como o modelo de empresas líderes das Cadeias Líderadas pelos Compradores ou Buyer Driven Chains - BDC, e também por empresas fornecedoras de insumos e serviços correlatos. Em sua totalidade, elas atuam prioritariamente no mercado interno. 
No caso de Honduras se escolheu a indústria maquiladora de roupas para a exportação, que tem sido o setor importante nas recentes estratégias de industrialização e exportação, na geração de emprego e no crescimento das exportações hondurenhas.

Por razões de menor tempo disponível, logística e recursos econômicos, a pesquisa se realizou em 9 empresas - 4 importantes maquiladoras para a exportação e 5 empresas atuando no mercado interno. Embora o foco da pesquisa fosse analisar as trajetórias das maquiladoras, as empresas de atuação nacional fornecem subsídios para avaliar a repercussão da maquila no ambiente industrial nacional.

Em ambos os casos, executivos de associações empresariais e empresas líderes foram entrevistados no início da pesquisa. Além de conhecer a atuação destas entidades, visava-se estabelecer contatos iniciais e validar o questionário guia para a entrevista semi-estruturada.

\subsubsection{Amostra e realização da pesquisa em Honduras}

Em Honduras, a amostra também foi intencional. Buscando, dentro do possível, representar a composição da IMHR e seu entorno, as empresas nacionais foram entrevistadas para avaliar vínculos com a indústria e o mercado local. A amostra ficou constituída como mostra a tabela 4.1 a seguir: 
Tabela 4.1 - Distribuição das empresas constituintes da amostra em Honduras

\begin{tabular}{|c|c|c|}
\hline Produtoras de insumos & Produtoras têxteis e de confecção & Distribuição e varejo \\
\hline \multicolumn{2}{|c|}{$\begin{array}{l}2 \text { Maquiladoras nacionais integradas produção de tecidos à confecção de vestuário } \\
\text { (roupa íntima, malharias, calças e camisas de tecido plano) } \\
\text { 1Maquiladora nacional de confecção de vestuário (roupa íntima, camisetas) } \\
1 \text { Empresa Estrangeira integrada, da fiação à comercialização, com serviços full-package }\end{array}$} & \multirow[t]{3}{*}{$\begin{array}{l}1 \text { Rede de Lojas de departamento } \\
\text { nacional }\end{array}$} \\
\hline & 1 Microempresa faccionista full-package & \\
\hline & 1 Grande empresa têxtil nacional & \\
\hline & \multicolumn{2}{|c|}{1 Pequena empresa de confecção e comercialização de roupas femininas de marca } \\
\hline & \multicolumn{2}{|c|}{1 Microempresa informal de confecção que tem seus próprios canais de comercialização } \\
\hline
\end{tabular}

Ademais se entrevistaram dirigentes de associações empresarias, de instituições promotoras das exportações e de ONGs, que trabalham na área de desenvolvimento industrial e social do país, e acadêmicos que estudam, principalmente, a situação do trabalhador.

A pesquisa de campo teve 3 etapas - duas visitas pessoais a Honduras - e posteriores entrevistas realizadas por uma colaboradora. A primeira visita ocorreu em outubro de 2001, na qual realizaram-se contatos iniciais com acadêmicos, dirigentes de associações empresariais, empresários e promotores de exportações. Houve a oportunidade de se assistir a um seminário de uma consultora estadunidense promovido pela AHMA.

Na segunda visita, em maio de 2002, aconteceram as visitas às empresas maquiladoras e às microempresas com atuação nacional. Entrevistou-se funcionários de ONGs e instituições nacionais e internacionais que trabalham em prol do desenvolvimento industrial, para se saber sobre a situação dos trabalhadores nas maquilas. Obteve-se mais contatos acadêmicos e por meio de várias destas pessoas, houve acesso a documentos e a estudos relativos à maquila, especialmente na biblioteca do FIDE. 
A terceira parte foi complementada com a colaboração de uma professora universitária, que realizou as entrevistas na empresa varejista e na empresa de confecção de marca de moda, já em 2003. A seguir, na tabela 4.2, apresenta-se a classificação destas empresas, segundo os modelos teóricos do estudo.

Tabela 4.2 - $\quad$ Classificação das empresas da amostra em Honduras de acordo com as categorias de Modernização Industrial

\begin{tabular}{|c|c|c|c|}
\hline $\begin{array}{l}\text { Novo modelo de } \\
\text { organização } \\
\text { de GCC }\end{array}$ & $\begin{array}{l}\text { Número de } \\
\text { empresas na } \\
\text { amostra }\end{array}$ & Características & $\begin{array}{l}\text { Tipologia de } \\
\text { modernização } \\
\text { industrial }\end{array}$ \\
\hline \multicolumn{4}{|c|}{ EMPRESAS INTEGRANTES DAS CPTVs } \\
\hline Varejista* & 1 & 1 Rede de Lojas de Departamento nacional & $\begin{array}{l}\text { COMPRADOR DE } \\
\text { MARCAS } \\
(\mathbf{N})\end{array}$ \\
\hline $\begin{array}{l}\text { Produtor com } \\
\text { marca* }\end{array}$ & 1 & $\begin{array}{l}1 \text { Pequena empresa de confecção e comercialização } \\
\text { de roupas femininas de marca em nível nacional }\end{array}$ & $\begin{array}{l}\text { PRODUTOR COM } \\
\text { MARCA } \\
(\text { OBM }-\mathbf{N})\end{array}$ \\
\hline $\begin{array}{l}\text { Fornecedores de } \\
\text { pacotes completos } \\
\text { com marca }\end{array}$ & 1 & $\begin{array}{l}1 \text { Microempresa faccionista full-package para o mercado } \\
\text { local }\end{array}$ & $\begin{array}{l}\text { PRODUTORES DE } \\
\text { DESIGN } \\
\text { ORIGINAL } \\
\text { (ODM - N) }\end{array}$ \\
\hline $\begin{array}{l}\text { Fornecedores de } \\
\text { pacotes completos } \\
\text { com design }\end{array}$ & 1 & $\begin{array}{l}1 \text { Maquiladora nacional integrada da produção de } \\
\text { tecidos à confeçãa de vestuário, com capacidade de } \\
\text { full-package incluindo design (subcontratado) }\end{array}$ & $\begin{array}{l}\text { MAQUILADORA } \\
\text { FULLPACKAGE } \\
\quad(\text { ODM })\end{array}$ \\
\hline $\begin{array}{l}\text { Fornecedores de } \\
\text { pacotes completos }\end{array}$ & 2 & $\begin{array}{l}1 \text { Maquiladora nacional integrada da produção de } \\
\text { tecidos à confecção de vestuário } \\
1 \text { Empresa Estrangeira integrada da fiação à } \\
\text { comercialização, com serviços full-package }\end{array}$ & $\begin{array}{l}\text { MAQUILADORAS } \\
\text { (OEM) }\end{array}$ \\
\hline Faccionistas & 1 & 1 Maquiladora nacional de confecção de vestuário & $\begin{array}{l}\text { MAQUILADORAS } \\
\text { (OEA) }\end{array}$ \\
\hline $\begin{array}{l}\text { Fornecedores de } \\
\text { tecidos }\end{array}$ & 1 & $\begin{array}{l}1 \text { Grande empresa têxtil nacional integrada até à } \\
\text { comercialização }\end{array}$ & PRODUTORES \\
\hline Produtor local & 1 & $\begin{array}{l}1 \text { Microempresa informal de confecção que tem seus } \\
\text { próprios canais de comercialização }\end{array}$ & (OEM) \\
\hline
\end{tabular}

Obs: $\mathbf{N}$ : que atua somente no mercado nacional

* entrevistas relizadas em 2003, por um conultor contratado. 


\subsubsection{A pesquisa de campo e resultados no Brasil}

Inicialmente pensou-se na elaboração de uma matriz do tipo insumo-produto que representasse o universo das cadeias têxtil-vestuário, dada a diversidade de empresas e a multiplicidade de produtos, processos e arranjos organizacionais temporais e permanentes. Esta logo se mostrou inviável pelos motivos expostos e pelas limitações de tempo e recursos econômicos.

A complexidade da indústria e das estatísticas, no que diz respeito à importação e exportação quanto ao consumo interno, agravados pela informalidade, pelo contrabando e pela subvaloração alfandegária, assim como as questões de sigilo num mercado extremamente competitivo, constituíram-se em limitantes para a análise, que foi complementada com dados de fontes diversas, nem sempre convergentes.

Por tais motivos, a pesquisa realizou-se com base em uma seleção intencional prévia de empresas dos principais elos (produtoras de fibras, têxteis, vestuário varejistas e fornecedores de insumos) destacadas em estudos setoriais prévios, na imprensa espe cializada e por indicação das associações ou empresas, no início da pesquisa. A amostra ficou constituída como mostra a tabela 4.3, na continuação:

Tabela 4.3 -

Distribuição das empresas constituintes da amostra no Brasil

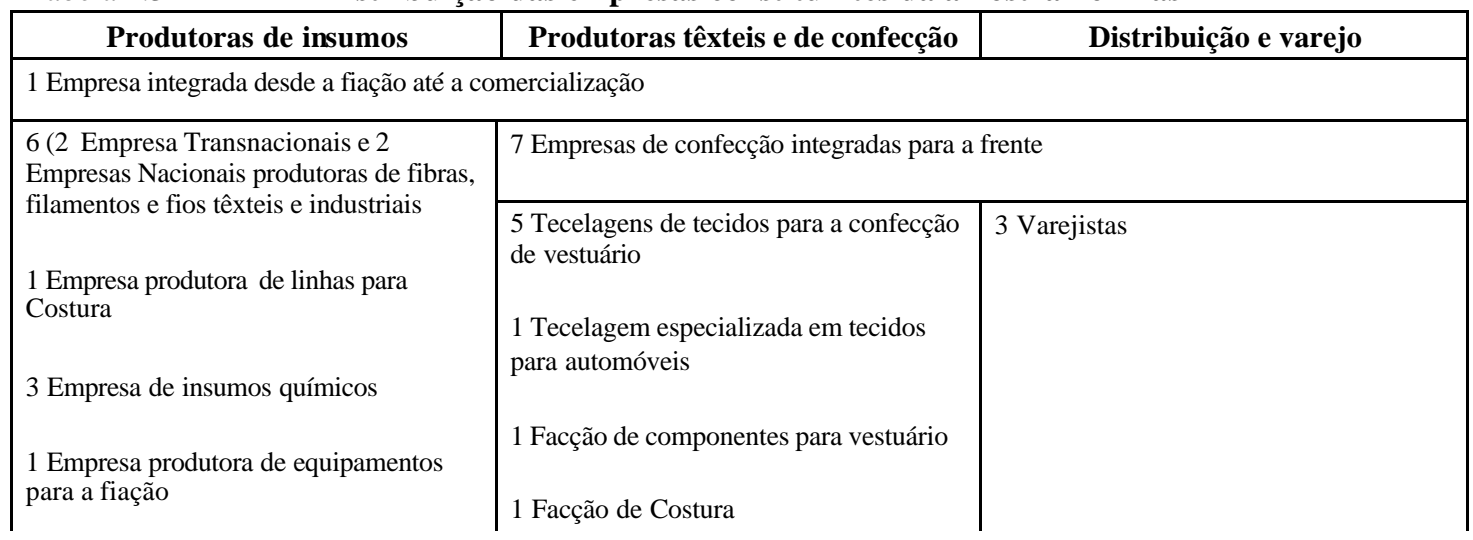


Classificando-as de acordo com a tipologia dos novos modelos de organização se tem como resultado a seguinte tabela 4.4.

Tabela 4.4 -

Classificação das empresas da amostra no Brasil, de acordo com as categorias de Modernização Industrial

\begin{tabular}{|c|c|c|c|}
\hline $\begin{array}{l}\text { Novo modelo de } \\
\text { organização } \\
\text { De GCC }\end{array}$ & $\begin{array}{l}\text { Número de } \\
\text { empresas na } \\
\text { amostra }\end{array}$ & Características & $\begin{array}{l}\text { Tipologia de } \\
\text { modernização } \\
\text { industrial }\end{array}$ \\
\hline \multicolumn{4}{|c|}{ EMPRESAS INTEGRANTES DAS CPTVS } \\
\hline $\begin{array}{l}\text { Produtores com } \\
\text { marca }\end{array}$ & 4 & $\begin{array}{l}1 \text { Rede multinacional de varejo especializado produção } \\
\text { terceirizada } \\
2 \text { empresa integradas desde a fiação até o varejo de marcas } \\
\text { (com mais ênfase no varejo **) } \\
1 \text { Confecção nacional de alta moda, assinada por estilista de } \\
\text { renome internacional } \\
1 \text { grande confecção (multinacional) com marcas de } \\
\text { reconhecimento nacional e internacional } \\
1 \text { grande empresa produtora de meias e artigos de malha de } \\
\text { marcas nacionais e licenças internacionais } \\
1 \text { grande empresa produtora de meias e lingerie de marcas } \\
\text { originais de renome nacional e fornecedora fultpackage de } \\
\text { marcas internacionais } \\
1 \text { média empresa produtora de moda feminina de marca } \\
\text { original reconhecida }\end{array}$ & $\begin{array}{l}\text { COMPRADORES DE } \\
\text { MARCA * } \\
\text { (GB) } \\
\text { PRODUTORES COM } \\
\text { MARCA } \\
\text { (OBM) }\end{array}$ \\
\hline $\begin{array}{l}\text { Fornecedores de } \\
\text { pacotes completos } \\
\text { com marca }\end{array}$ & 1 & $\begin{array}{l}1 \text { média empresa de moda atacadista e fornecedora } \\
\text { full-package com competências de design com ou sem } \\
\text { marca própria }\end{array}$ & $\begin{array}{l}\text { PRODUTORES DE } \\
\text { DESIGN ORIGINAL } \\
\text { (ODM) }\end{array}$ \\
\hline $\begin{array}{l}\text { Fornecedores de } \\
\text { pacotes completos }\end{array}$ & 2 & $\begin{array}{l}\text { Empresas de pequeno e médio porte atendendo às demandas } \\
\text { de grandes compradores e também aos mercados locais e } \\
\text { regionais: } \\
2 \text { média empresas produtora de artigos de malha }\end{array}$ & \multirow{3}{*}{$\begin{array}{c}\text { PRODUTORES DE } \\
\text { EQUIPAMENTO } \\
\text { ORIGINAL } \\
(\text { OEM) }\end{array}$} \\
\hline $\begin{array}{l}\text { Fornecedores de } \\
\text { tecidos }\end{array}$ & 5 & $\begin{array}{l}2 \text { grandes empresas brasileiras ( } 1 \text { multinacional) de tecidos } \\
\text { de algodão e misturas } \\
3 \text { médias empresas de tecido sintéticos }\end{array}$ & \\
\hline $\begin{array}{l}\text { Fornecedores de } \\
\text { fibras }\end{array}$ & 6 & $\begin{array}{l}4 \text { subsidiarias de empresas multinacionais } \\
2 \text { empresa nacionais de médio porte }\end{array}$ & \\
\hline $\begin{array}{l}\text { Fornecedores } \\
\text { Especializados }\end{array}$ & 1 & 1 empresa de acabamento de tecidos & \multirow{2}{*}{$\begin{array}{l}\text { MAQUILADORAS } \\
\text { (OEA) }\end{array}$} \\
\hline Faccionistas & 2 & $\begin{array}{l}1 \text { facção de costura } \\
1 \text { facção de componentes (golas e punhos) para confecção de } \\
\text { artigos de malha }\end{array}$ & \\
\hline \multicolumn{4}{|c|}{ EMPRESAS DE INDÚSTRIAS CORRELATAS DAS CPTVS } \\
\hline \multirow{3}{*}{$\begin{array}{l}\text { Fornecedoras de } \\
\text { Insumos químicos** }\end{array}$} & \multirow[t]{3}{*}{4} & $\begin{array}{l}1 \text { subsidiaria de multinacional produtora de insumos } \\
\text { químicos básicos }\end{array}$ & \multirow[t]{2}{*}{ OEM } \\
\hline & & 1 empresa nacional de insumos químicos básicos & \\
\hline & & $\begin{array}{l}1 \text { subsidiaria de multinacional de insumos químicos básicos e } \\
\text { especiais para têxteis }\end{array}$ & OBM \\
\hline $\begin{array}{l}\text { Fornecedora de } \\
\text { equipamentos** }\end{array}$ & 1 & 1 subsidiaria fornecedora de equipamentos para fiação & OEM \\
\hline
\end{tabular}

Obs: * utiliza-se aqui “COMPRADORES DE MARCA” como interpretação livre dos Global Buyers - GB, pela predominância de empresas nacionais sobre as internacionais ( 3 a 1) na amostra, embora as compras de insumos se façam parcialmente no exterior.

* * Em ambos os casos grande parte da confecção é terceirzada, quando não em sua totalidade. 


\section{CAPÍtulo 5}

\section{RESUlTADOS DA PESQUISA DE CAMPO \\ E ANÁLISE DOS CASOS}

Este capítulo apresenta os resultados da pesquisa de campo e a análise dos casos, primeiro individualmente e em seguida comparativamente.

A evolução ocorrida nas empresas analisadas é modelada sob a abordagem conceitual de Progressão Industrial, tentando verificar os avanços obtidos em função das estratégias implementadas pelas empresas hondurenhas e brasileiras nas respectivas Cadeias Produtivas Têxtil-Vestuário - CPTV em que atuam.

Primeiro se modelam as trajetórias das empresas da Indústria Hondurenha Maquiladora de Roupas - IHMR inseridas nas Cadeias Produtivas Têxtil-Vestuário -CPTV, cuja produção é exportada principalmente para os Estados Unidos. Também se modelam as trajetórias de algumas empresas que atuam somente no mercado nacional.

No caso do Brasil, se modelam as trajetórias das empresas Ideres de CPTV no país, destacando aquelas que incursionam no mercado internacional com produtos de qualidade e marcas originais próprias. 
No final de cada caso, comparam-se as competências alcançadas pelas empresas e CPTV nos períodos analisados, ou seja, do início da década de 80, que marca o boom das novas maquilas hondurenhas, e do início da década de 90, no caso do Brasil, na qual ocorrem grandes mudanças nas estruturas interempresarias das CPTV brasileiras, até o início do século XXI, em ambos países.

A partir dessa análise tenta-se responder às perguntas inicias da tese.

\section{1}

\section{Análise das trajetórias das empresas hondurenhas sob a abordagem de Progressão Industrial}

Feita a classificação apresentada na tabela 4.2., no capítulo anterior, e com o panorama geral construído inicialmente, procede-se à análise sob a abordagem da Progressão Industrial das trajetórias das empresas da amostra. Primeiro, apresenta-se a análise das trajetórias empresariais das maquiladoras nacionais, seguida da trajetória da empresa maquiladora estrangeira, para finalmente relatar as trajetórias das empresa nacionais atuando no mercado local, tentando verificar se há vínculos entre as maquiladoras e as empresas que atuam somente no mercado nacional.

\subsubsection{Trajetórias das empresas maquiladoras em Honduras}

\subsubsection{As trajetórias das maquiladoras de capital nacional}

As três empresas maquiladoras hondurenhas estudadas pertencem a grupos econômicos com tradição na produção e comércio de têxteis e vestuário no país, anteriores à maquila, uma delas desde meados da segunda década do século 20, e ambos 
consolidados durante o período de Industrialização por Substituição de Importações ISI. As três atuam sob o regime de Zona Livre.

Em ordem inversa à de Modernização Industrial apresentam-se, a seguir, as trajetórias dessas empresas.

A primeira empresa tem tradição na confecção e comércio de roupas com marca original, principalmente uniformes. Foi uma das primeiras a trabalhar sob regime de draw-back para os Estados Unidos, e é uma das propulsoras dos primeiros parques industriais e administradora de Zonas Livres.

Suas competências mercadológicas vão desde as produtivas até a administração de parques industriais. Chegou a ter nove parcerias financeiras internacionais, restando somente duas em 2002. A integração vertical, à jusante e à montante, se realiza com a pretensão de chegar ao pacote completo, inclusive com design. Esta atividade, inicialmente, é subcontratada num escritório de design nos Estados Unidos ${ }^{57}$, até a empresa desenvolver internamente essa competência.

Em 2002, 80\% de sua produção já é de pacote completo (sem desenho) e participa de tomadas de pedidos virtuais. Até a data da entrevista, a empresa tinha ganho três das cinco concorrências em que participou.

A empresa passou por um processo de reengenharia quando começaram a operar como 807, afirmaram utilizar os métodos japoneses da organização do trabalho como o JIT, e trabalho flexível.

Seus investimentos em tecnologia vão até a introdução de robôs em certas fases do processo. A empresa estuda investir em sistemas de comunicação via satélite ou via cabo

\footnotetext{
${ }^{57}$ Esta empresa antes de atuar como maquiladora, chegou a realizar investimento numa planta têxtil na Carolina do Sul, Estados Unidos, que no final não resultou bem sucedido.
} 
para suprir as carências da rede nacional de telecomunicações. A figura 5.1 sintetiza sua trajetória.

Fig. $5.1-$

Empresa fornecedora de pacote completo inclusive design

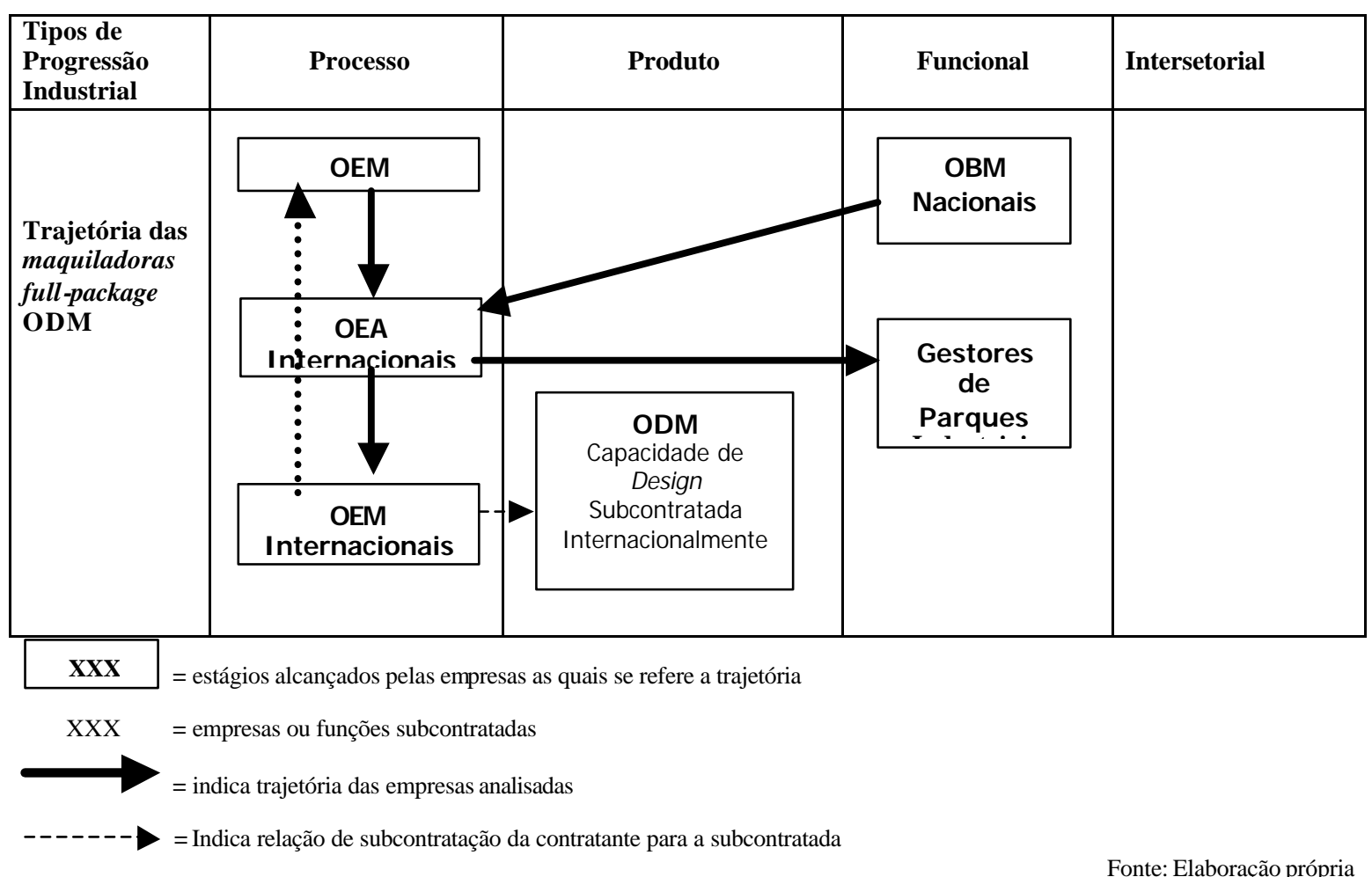

A segunda empresa, de capital nacional teve origem na fabricação de tecidos, sendo ainda a sua principal competência, e atua como fornecedora de pacotes completos e para isto subcontrata a confecção.

Já exportou para Europa e Japão, mas seu principal mercado são os Estados Unidos. $65 \%$ das relações com os seus clientes são parceiros de longa data considerados como alianças estratégicas; o restante são temporais.

Seu processo de aprendizado passa pelo benchmarking de outras empresas, especialmente de clientes dos Estados Unidos. A empresa utiliza sistemas Electronic 
Data Interchange - EDI para as vendas e Global Sourcing virtual para a compra de insumos.

Tem um elevado quadro de profissionais universitários capacitados, e a gestão da empresa é profissionalizada. A seguir, a figura 5.2. apresenta sinteticamente sua trajetória.

Fig. 5.2 - $\quad$ Empresa fornecedora de tecidos e de vestuário - pacote completo

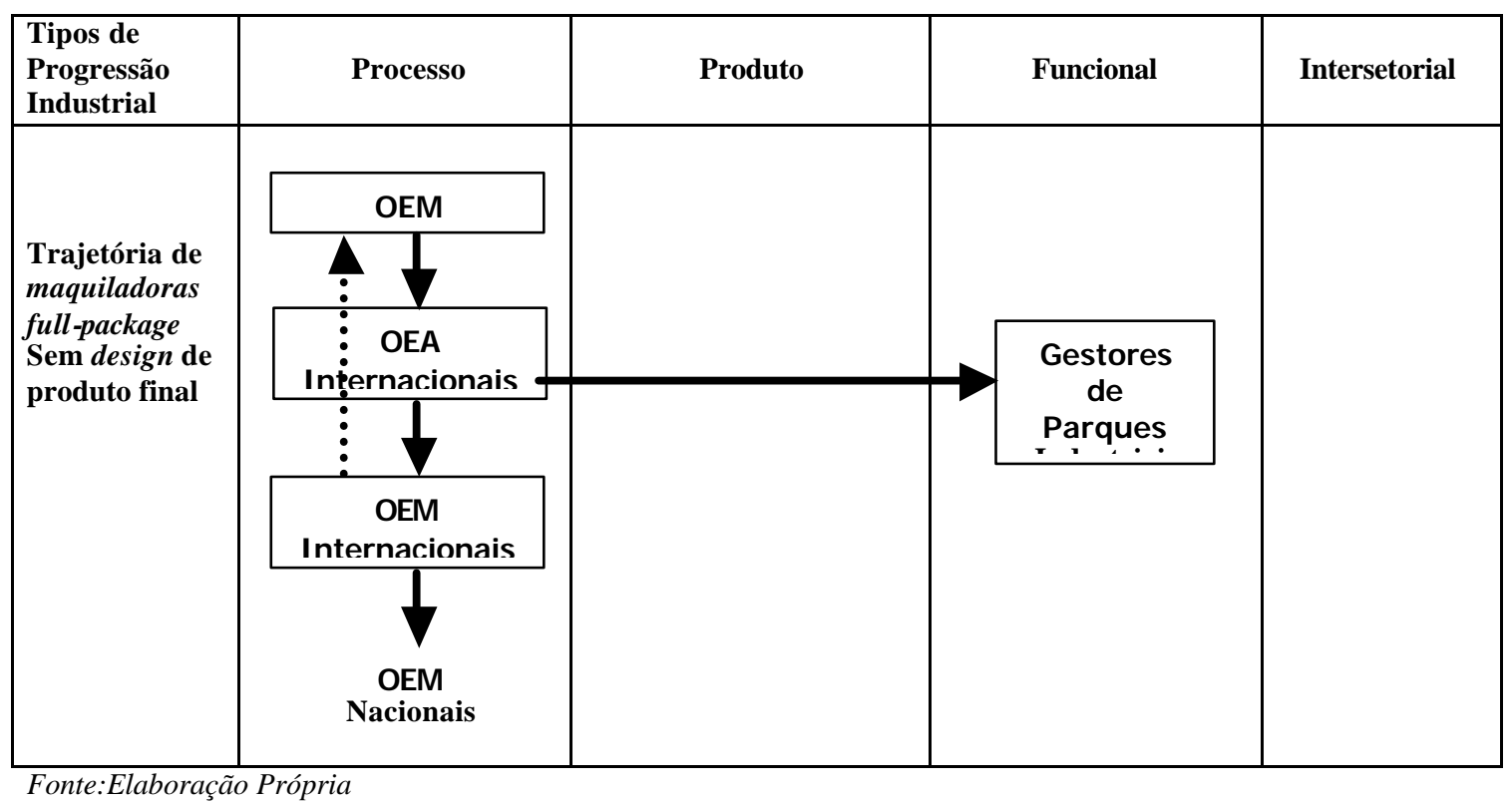

Estas duas primeiras empresas diversificaram suas atividades até o grau de atuar como imobiliárias (propaganda no catálogo da AHMA 2000-2001), importação, etc., porém, apesar de entrar em outros setores, considera-se que a maioria são atividades complementares de sua atividade principal: a maquila de roupas. Não se descarta, entretanto, que nestes, ou como já há em outros parques industrias, estejam ou venham a desenvolver-se outras atividades diferentes da maquila de roupas. 
O terceiro caso, uma empresa maquiladora mais nova, localizada em Tegucigalpa, onde a maquila chegou posteriormente com as sucessivas reformas e ampliações dos regimes de maquilas. Sua trajetória ainda é mais curta, apesar da origem do capital vir da indústria têxtil nacional tradicional.

Num dos andares da planta, as máquinas eram propriedade do cliente que estava introduzindo uma nova linha de produtos (para esta maquiladora), o que requeria equipamento novo e o aprender a fabricação de novos artigos. A empresa contratante entrou com o equipamento novo, o treinamento (com todos os custos), os materiais e a encomenda. A maquiladora entrou com o local e a gestão de pessoal. Ambas empresas já tinham negócios em comum, nos quais a operação e o equipamento eram da maquiladora.

Ao que prece, essa configuração é uma prática comum no início das relações entre clientes estadunidenses e maquiladoras iniciantes, assim, as empresas locais com pouco capital podem capitalizar-se e depois adquirir o equipamento. Por outro lado, as empresas internacionais contratantes vão testando a capacidade e a confiabilidade dos fornecedores. Um exemplo disto é o aprendizado e a progressão em processos (mesmo que básicos) e de desenvolvimento de fornecedores. Esta trajetória é apresentada, a seguir, na figura 5.3.

Fig. 5.3 -

Empresa maquiladora iniciante

\begin{tabular}{|l|c|c|c|c|}
\hline $\begin{array}{l}\text { Tipos de } \\
\text { Progressão } \\
\text { Industrial }\end{array}$ & Processo & Produto & Funcional & Intersetorial \\
\hline $\begin{array}{l}\text { Trajetória das } \\
\text { maquiladoras } \\
\text { Iniciantes }\end{array}$ & $\begin{array}{c}\text { OEM } \\
\text { Internacionais }\end{array}$ & & & \\
& $\begin{array}{l}\text { OEA } \\
\text { Internacionais }\end{array}$ & & & \\
\hline
\end{tabular}




\subsubsection{Trajetórias das empresas maquiladoras de capital estrangeiro}

Por último, apresenta-se o caso da empresa de capital taiwanês. Esta empresa, de capital familiar, iniciou operações em Honduras em 1990 como confecção numa Zona Industrial de Procesameinto para la Exportación - ZIP. Estimulada pelas preferências dos Estados Unidos para a Bacia do Caribe, e com assistência e crédito de bancos de Taiwan, gradualmente expandiu suas atividades à montante na CPTV em Honduras. Os investimentos realizados compreendem fiação, malharia, tingimento e estamparia centralizados no seu próprio parque industrial. A estratégia é chegar a fornecer pacotes completos (OEM).

O sócio-gerente da empresa já tinha tentado produzir calçados em Honduras. A seleção do país se fez depois de conhecer o potencial de outros países da região. A figura 5.4 mostra sua trajetória em Honduras.

Fig. 5.4 - Empresa Asiática fornecedora de tecidos e de vestuário - pacote completo

\begin{tabular}{|c|c|c|c|c|}
\hline $\begin{array}{l}\text { Tipos de } \\
\text { Progressão } \\
\text { Industrial }\end{array}$ & Processo & Produto & Funcional & Intersetorial \\
\hline $\begin{array}{l}\text { Trajetória das } \\
\text { maquiladoras } \\
\text { Asiáticas em } \\
\text { Honduras }\end{array}$ & $\begin{array}{c}\text { OEM } \\
\text { Internarinnais } \\
4 \\
\text { OEA } \\
\text { Internacionais }\end{array}$ & & & \\
\hline
\end{tabular}




\subsubsection{Empresas atuando no mercado nacional hondurenho}

\subsubsection{Empresas nacionais hondurenhas Produtoras com Marca}

Apresentam-se, a seguir, os casos de uma grande empresa têxtil e de uma pequena empresa produtora de vestuário feminino com marca para os nichos de maior poder aquisitivo, nas maiores cidades do país.

A empresa têxtil estudada é uma das primeiras a produzir tecidos em Honduras, atua no setor de tecidos básicos para vestuário e principalmente para o lar. A empresa fornece para grande parte do mercado nacional e exporta para a América Central e Estados Unidos. É uma empresa familiar e recentemente começou a profissionalizar sua gestão.

Esta empresa produtora de tecidos comercializa ela mesma seus produtos, tanto no atacado (incluindo a exportação) quanto no varejo, e localmente sua marca sempre foi símbolo de qualidade que adiciona valor para os seus tecidos.

A empresa não se converteu à maquila e continua líder no mercado nacional. Como muitas empresas, sofreu com o furacão Mitch, mas a perda total do maquinário possibilitou a modernização do mesmo. Recentemente, a mídia anunciou dificuldades.

A pequena empresa de confecção e comercialização de roupas femininas de marca, em nível nacional, uma das pioneiras no setor, cresceu no final da década de 80, passando de um "atelier" de moda a uma pequena "griffe", com lojas nas pincipais cidades do país, seu valor de marca se fundamenta no design e na exclusividade. São produções em pequena escala e com materiais de primeira qualidade, geralmente adquiridos de importadores no mercado local ou importados diretamente em viagens ao exterior. A produção é própria e formada por MDO altamente qualificada. 
Esta trajetória é similar à de outras marcas. Algumas com maior capacidade mantêm duas ou mais linhas/marcas para nichos de mercado diferentes. Sua trajetória local está representada, a seguir, na figura 5.5.

Fig. 5.5 - Empresas nacionais Produtoras com Marca

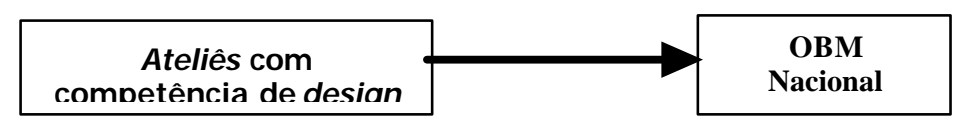

Este tipo de pequenas e médias empresas, baseadas em criatividade e necessidade de sigilo em suas coleções, freqüentemente não participa de associações comerciais ou entidades de classe, e não recebe apoio do governo. Não tem vínculos com a IHMR.

\subsubsection{As empresas de confecção do setor informal hondurenho}

Por último, além das tradicionais microempresas e oficinas de confecção do setor informal, apresenta-se, aqui, a trajetória de duas microempresas que têm relação também infor mal com a maquila.

Ambas as microempresas podem ser classificadas como pacote completo - OEM e pacote completo com design - ODM locais. Nestes casos, "locais" utiliza-se para designar a região metropolitana de San Pedro Sula (Centro Industrial do País e dos negócios da maquila) e, eventualmente, cidades vizinhas a esta, entre as quais o município de Choloma faz parte.

O mercado da primeira microempresa (OEM) é formado, em grande parte, por moradores locais, muitos dos quais trabalham na maquila. No segundo caso, a trajetória tem aproximadamente uma década. Inicia-se como pequena oficina faccionista para lojas especializadas de roupa infantil, passando, num segundo momento, a ofertar pacotes 
completos com design próprio. Na época da entrevista para esta pesquisa, a meta era ter maior controle sobre os canais de produção.

Ambos os empreendimentos recebiam apoio de projetos institucionais para o desenvolvimento das Pequenas y Medianas Empresas - PYMEs. A proprietária de um deles era diretora de uma associação local de PIMEs.

O interessante para a pesquisa é a sua relação com a IHMR Como já mencionado, ambas adquirem grande parte de matéria-prima da sobra das maquilas ${ }^{58}$ : equipamentos (novos e usados) e peças de reposição são acessíveis, a custos razoáveis, para os pequenos empresários locais.

O aprendizado de técnicas produtivas e conhecimentos sobre o equipamento e materiais são difundidos a partir dos revendedores e das maquilas, principalmente pela passagem dos trabalhadores pelas plantas maquiladoras (várias das empregadas tinham essa experiência). Já entre os proprietários, somente um. A figura 5.6., a seguir, resume a trajetória das duas microempresas.

58 Cabe ressaltar que há estritos controles sobre o desperdício das matérias-primas na IHMR, principalmente daqueles materiais que são importados com isenções tarifárias, com a dupla intenção de que ingressem em Honduras sem pagar impostos e para o controle quando os produtos elaborados ingressam no mercado americano. 
Fig. 5.6 - Microempresas do setor informal que florescem em torno damaquila

\begin{tabular}{|l|c|c|c|c|}
\hline $\begin{array}{l}\text { Tipos de } \\
\text { Progressão } \\
\text { Industrial }\end{array}$ & Processo & Produto & Funcional & Intersetorial \\
\hline $\begin{array}{l}\text { Trajetória da } \\
\text { Microempresa } \\
\text { OEM }\end{array}$ & OEM-L & & & \\
\hline $\begin{array}{l}\text { Trajetória da } \\
\text { Microempresa }\end{array}$ & OEM-L & & & \\
\hline ODM & ODM-L & & \\
\hline
\end{tabular}

Fonte: Elaboração própria.

Para finalizar, há indícios de redes de subcontratação que atuam somente em nível nacional, de forma informal, conhecidas como maquilas nacionais, não sendo o foco deste trabalho.

\subsubsection{Investimento das empresas nacionais na maquila hondurenho}

O fato da empresa continuar atendendo o mercado nacional e centro-americano, não implica que investimentos novos não sejam feitos na área da maquila, gerenciados por membros mais jovens da família. Os investimentos familiares das empresas nacionais na maquila podem ser considerados como trasbordamentos da indústria nacional para a maquila, como mostra a figura 5.7. O conhecimento anterior se somará ao aprendizado na cadeia, assim como o capital acumulado pelo comércio no país e pelas exportações tradicionais. 
Fig. 5.7 - Trasbordamentos de capital nacional para a maquila

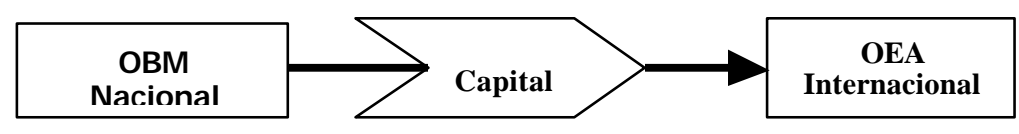

Fonte: Elaboração própria.

\subsubsection{Varejo de roupas em Honduras}

Na pesquisa, realizou-se entrevista com o setor de compras de uma das maiores redes de lojas de departamentos do país. No caso desta loja, compram-se algumas roupas em Honduras diretamente dos produtores nacionais. Como os produtos das maquilas não se comercializam localmente, alguns produtos de marcas internacionais importados podem ser fabricados em Honduras.

A maioria das compras procedem da América Latina: Panamá, México, Colômbia, Guatemala e Brasil; da Ásia, a maioria das roupas são adquiridas de Hong-Kong.

Um dos seus maiores concorrentes é um produtor local que atua exclusivamente no varejo de roupas com alto conteúdo de moda e design.

Existe ainda um grande percentual de comércio informal de roupas, alfaiates e costureiras domiciliares, e o comércio de roupas usadas que inicialmente entrava como doação do exterior.

Como já foi citado várias vezes, o comércio dos produtos da maquila em nível nacional é limitado a quotas (normalmente 5\%) da produção e ao pagamento das tarifas de importação, porém não se pode negar o comércio informal de produtos de segunda 
qualidade, e das sobras de tecidos e de alguns insumos. A composição do varejo interno hondurenho se apresenta na figura 5.8, a seguir.

Fig. 5.8 -

Composição do varejo interno hondurenho

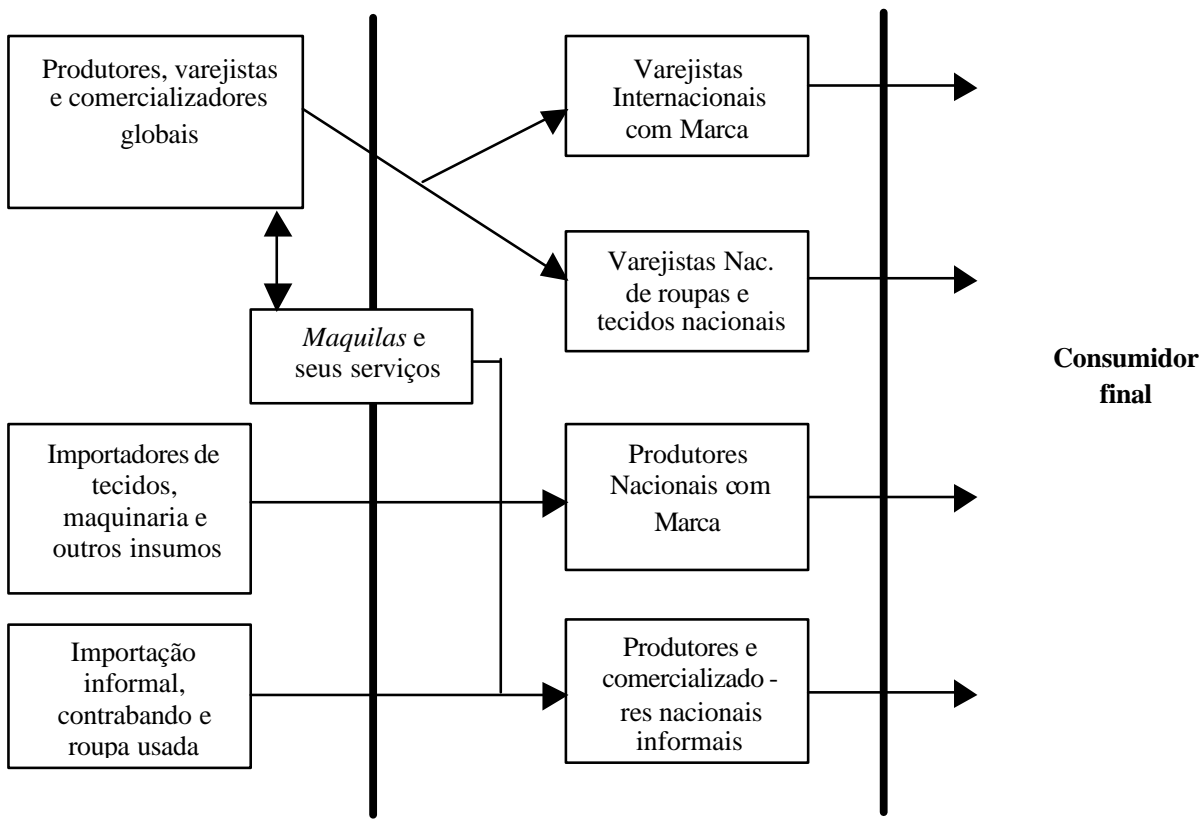

Fonte: Elaboração própria.

\subsubsection{Competências e Progressão Industrial na Indústria Hondurenha de Maquiladora de Roupas - IHMR}

Uma análise simplificada para verificar se houve Progressão Industrial nas quase duas décadas da maquila hondurenha, é verificar as competências ou atividades realizadas pelas maquiladoras no início e na atualidade. 
Percebe-se que a oportunidade de oferecer pacotes completos está possibilitando o investimento na produção de insumos e na integração vertical das cadeias produtivas, seja pelo investimento nacional ou pelo investimento internacional.

A figura 5.9 sintetiza uma comparação das competências das maquiladoras no início do funcionamento dos regimes de maquilas, no começo da década de 80 e no momento da pesquisa.

Fig. 5.9 -

Competências das maquiladoras hondurenhas no início da década de 1980 e início do Séc. XXI

\begin{tabular}{|c|c|c|c|c|c|c|c|c|c|}
\hline Atividades & Fiaçãoo & $\begin{array}{c}\text { Tece } \\
\text { lagem }\end{array}$ & $\begin{array}{c}\text { Aca } \\
\text { ba } \\
\text { mento }\end{array}$ & Design & $\begin{array}{l}\text { Confecção/ } \\
\text { malharias }\end{array}$ & $\begin{array}{l}\text { Confecção } \\
\text { de pacotes } \\
\text { completos } \\
\end{array}$ & $\begin{array}{c}\text { Gestão da } \\
\text { cadeia de } \\
\text { fornecedores }\end{array}$ & $\begin{array}{c}\text { Logística e } \\
\text { distribuição }\end{array}$ & $\begin{array}{c}\text { Comercialização } \\
\text { de produtos com } \\
\text { marca original }\end{array}$ \\
\hline $\begin{array}{l}\text { Competên- } \\
\text { cias no nível } \\
\text { nacional e } \\
\text { de C.A. } \\
\text { Antes da } \\
\text { maquila }\end{array}$ & & & & & & & $*$ & & \\
\hline $\begin{array}{l}\text { Momento } \\
\text { inicial } \\
\text { década de } \\
1980\end{array}$ & & & & & & & & & \\
\hline $\begin{array}{l}\text { Momento } \\
\text { da pesquisa } \\
2002\end{array}$ & & & & & & & & & \\
\hline
\end{tabular}

d' = Competências parciais ou em processo de aquisição.

* As competências para a gestão de fornecedores, assim como as demais, eram mais simples por causa da época e pela dimensão e baixa complexidade do mercado nacional.

Fonte: Elaboração própria. 

brasileiras

\subsubsection{CPTV brasileiras e empresas líderes de acordo com o modelo de Global Commodity Chains - GCC}

\subsubsection{As empresas Produtoras com Marca nas CPTV brasileiras}

A pesquisa identificou dois tipos de estratégias ou tendências das empresas produtoras tradicionais, que se reestruturam para: (a) obter competências à jusante ligadas às funções mercadológicas. Estas empresas administram seus canais de comercialização e chegam até o varejo com redes de lojas próprias, franquias ou licenças que utilizam suas marcas, eventualmente deixando a produção e focando no varejo; serão consideradas como varejistas no item correspondente, (b) construir uma maior integração interempresarial e especialização, bem como focalizar em competências essenciais de cada empresa para a definição conjunta de produtos, parâmetros e procedimentos. Estas empresas fornecem para lojas de departamentos e grande varejo, ou para lojas especializadas multimarcas.

As empresas que seguem a segunda estratégia são as consideradas como Produtoras com Marca, podendo-se citar diversos tipos que se exemplificam a seguir:

As grandes empresas integradas exportadoras do Brasil, já citadas, além de atuar com marcas próprias, também são fornecedoras de insumos/produtos finais através de subcontratações, licenciamentos e fornecimento de matérias-primas ou insumos intermediários com grande valor de marca - como é o caso dos tecidos Santista - para outras companhias nacionais e internacionais, tanto comercializadoras com marca como varejistas. Empresas no início da cadeia, como a Dupont, têm marcas como Lycra, que adicionam muito valor agregado aos produtos finais de vestuário que a utilizam. 
Outro grupo de importância no país que se insere nesta categoria, está constituído por empresas de porte médio, confecções e malharias, tradicionalmente verticalizadas, mas que utilizam a subcontratação principalmente na etapa da costura, atendem ao mercado nacional com estratégias diversas. Entre elas destacam-se a Hering, De Millus e Marisol, responsáveis por $36,1 \%$ da receita do segmento, de acordo com o Balanço Anual da Gazeta Mercantil em 2001. São empresas também Produtoras de Marca, mas que atuam cada vez mais no varejo e investem fortemente nas competências necessárias para a competitividade nesse elo.

$\mathrm{Na}$ área de tecidos sintéticos, algumas tecelagens de médio porte, que estão integradas nas cadeias mais dinâmicas lideradas pela moda, estão ganhando fama como produtoras de tecidos de alta qualidade e propriedades inovadoras. Embora não liderem a cadeia, esta associação adiciona valor aos seus tecidos, utilizados pelas marcas mais importantes da moda brasileira. Elas também trabalham em conjunto como os fornecedores de fibras e de acabamentos internacionais atuando no Brasil, formando assim um ciclo virtuoso que retribui em maior valor às marcas de todos os produtos ou insumos de cada elo da cadeia.

Também atuam como produtoras como marca, empresas internacionais estabelecidas recentemente no Brasil, como a Sara Lee, que adquiriu a maior produtora de roupa íntima masculina, a Zorba, mas que não possui varejo próprio. Há mais tempo no Brasil atuam empresas como a VF e a Levi's, que inicialmente operavam com instalações próprias. Porém, recentemente, enxugaram suas linhas de produção terceirizando ou importando e sua comercialização se dá através de lojas de departamentos e licenciamento da marca, em outros casos.

Em ambos os casos, há uma preocupação crescente com as atividades relacionadas ao mercado. A questão estratégica passa pelo entendimento dos diferentes canais de comercialização, clientes e consumidor final em todas as suas dimensões, para poder 
avaliar gostos e tendências que permitem o design adequado, a valorização da marca e a disponibilidade dos produtos no ponto de venda mais apropriado.

Sem essas informações, a empresa perde autonomia em suas estratégias e fica "dependente" da cadeia de fornecimento, em desvantagem frente à concorrência e, principalmente, frente aos clientes varejistas.

Por causa dos ciclos curtos de vida dos produtos, há também uma preocupação com a rápida e correta definição dos insumos de produção (fibras, tecidos e acabamentos) e das informações de tendências que vão proporcionar as qualidades do produto almejadas pelos clientes. Conseqüentemente, há investimentos em Pesquisa (de tendências) e (especialmente) Desenvolvimento para dialogar com os produtores de fibras e de insumos químicos para o acabamento.

Cada vez mais as atividades de produção são terceirizadas, na medida em que não se prejudique a qualidade e os custos; para isso, a empresa tem que dominar os conceitos e a prática de Gestão da Cadeia de Suprimentos e a Logística, caso contrário perderá controle da produção e a eficiência necessária no ciclo do produto.

Nessa cadeia de fornecedores, as tecelagens de pequeno porte e as empresas faccionistas de costura formam o elo de produção, que fica emparedado entre as grandes fornecedoras de fibras e as grandes demandantes da indústria do vestuário, é o elo com as maiores fraquezas. Entre elas, surgem as novas prestadoras de serviços, os Fornecedores de Pacotes Completos, que nos moldes descritos anteriormente atuam como fornecedoras de pacotes completos - OEM, produzindo para outras marcas, e também como produtoras com marca - OBM, quando os produtos são comercializados com suas próprias marcas e são estas que agregam valor. 


\subsubsection{Cadeias Produtivas lideradas pelas Comercializadoras com Marca}

As empresas Comercializadoras líderes da CPTV brasileiras já nasceram muito fortes em Marketing e Design e pouco ou nada se envolveram em atividades de produção. Principalmente as empresas mais jovens, que fundamentam o valor de sua marca no design e no nome dos estilistas criadores, nasceram enxutas. Muitas vezes suas produções iniciais eram realizadas internamente, porém à medida que a marca se consolida e a sua produção cresce e se diversifica, é terceirizada para os produtores ou faccionistas, suas instalações produtivas limitam-se a realizar protótipos ou séries pequenas, geralmente as mais exclusivas e de alto valor.

O investimento em produção minimiza -se e os recursos podem dirigir-se a outras áreas de competências essenciais, como promoção e marketing.

Apresentam estas trajetórias empresas detentoras de marca com alto valor agregado pelas marcas, que comercializam seus produtos em pequenas redes de produtos exclusivos próprios, ou de varejo especializado exclusivas, como a Zoomp, M. Officer, Ellus, entre outras ${ }^{59}$.

\footnotetext{
${ }^{59}$ Destacam-se as empresas comandadas por estilistas que, além de firmarse no mercado nacional, estão tentando um lugar no competitivo mercado internacional da moda. Como mostra Caixeta (2002), eles realizam consideráveis investimentos para aumentar suas vendas no exterior. Os estilistas Alexandre Herchcovitch e Walter Rodrigues, que têm assessorias de imprensa na Europa, são os únicos a desfilar em Paris. Herchcovitch também investiu US\$ 130.000 para a semana de moda de New York. Também em New York, Amir Slama e Carlos Miele, da Rosa Chá e da M.Officer, respectivamente, apresentaram suas coleções, onde receberam críticas elogiosas e augúrios de sucesso das coleções de primavera e verão para o público de jovens profissionais que investem em moda como forma de auto-expressão.
}

A M.Offcer de Miele, eleita a melhor empresa do setor pela revista Melhores e Maiores da Exame em 2001, faturou, nesse ano, US\$59,1 milhões e no Brasil pode ser encontrada em 61 lojas próprias, 32 franquias e 350 pontos multi-marcas no Brasil.

A Zoomp, um pouco na frente, já tem postos de venda em 16 países ao redor do mundo. A Forum que exporta $2 \%$ da sua produção, segue estratégia diferente. No exterior há mais de 4 anos mantém showroom próprio em New York, a partir dali suas peças são comercializadas em lojas de departamentos como Sak's, Nordstrom e Bergdorf Goodman. No total a marca de Tufi Duek está presente em 120 pontos de venda nos Estados Unidos e mais 100 em outros países, incluindo o Japão e a China. Assim como os jeans da Zoomp, os da Ellus começam a vender-se nas galerias Lafayette, em Paris. 
Por sua propensão para atividades de moda (formadoras de gosto), operam inicialmente em pequena escala, há menores investimentos na parte tecnológica e uma maior dependência de fornecedores qualificados.

Elas concorrem com produtos importados de marcas européias como Armani e Hugo Boss, entre as mais tradicionais, e a espanhola Zara, recém chegada ao país, que importa sua produção ao redor do mundo e começou, em 2003, a avaliar fornecedores de roupa infantil (ABIT, 2003). Empresa como estas operam também no Brasil com importação ou com produção subcontratada pelas grandes marcas de artigos esportivos como Nike, Reebok, Adidas e as de jeans como Levi's e Wrangler, entre outras.

\subsubsection{O varejo de roupas no Brasil}

O varejo de produtos de preço médio está passando por uma reestruturação, influenciada também pela moda - em suas estratégias têm enorme peso o design e a publicidade. As empresas C\&A, Riachuelo e Renner atuavam em segmentos de consumidores populares (C e D), mas investem em moda para alcançar a classe B de jovens de 15 a 39 anos, ligados nas tendências da moda.

A holandesa C\&A é pioneira no Brasil, transformando a moda em artigos de consumo popular. A C\&A, com abrangência nacional, tem sua produção sub-contratada nacionalmente em muitas pequenas e médias confecções. A empresa tem realizado um trabalho muito intenso no desenvolvimento de fornecedores, chegando hoje somente a definir as tendências de estilo, depois escolhendo a partir dos protótipos e preços apresentados pelos fornecedores.

A potiguar Riachuelo, que responde pelo varejo do grupo Guararapes, tem estratégias inovadoras próprias. Recentemente passou de um meio de escoamento dos produtos padrão do grupo para a comercialização de roupas com alto conteúdo de moda e lançamentos sazonais, de acordo com os calendários da moda. A empresa está 
investindo forte na revalorização da marca promovendo eventos de moda e modelagem, terceirizando grande parte de sua produção, controlada por gestores de moda.

No mesmo segmento compete a gaúcha Renner, recente aquisição da americana JC Penney. Em 1999, o grupo teve um faturamento de 406 milhões de reais e espera aumentar em cerca de $65 \%$ o seu faturamento neste ano. Para atingir essa meta de crescimento, a empresa planeja a abertura de novas lojas. Já em 2000, a Renner tinha 47 lojas espalhadas pelos estados do Rio Grande do Sul, Paraná, Santa Catarina, Rio de Janeiro, Distrito Federal, Minas Gerais, Goiás e São Paulo. (Bento. 2000).

As três empresas representam 3\% do varejo de roupas do Brasil (R $\$ 100$ bilhões, na ordem de US\$ 29 bilhões). Somadas, abriram 42 novas lojas entre 1999 e 2002, fazendo um total de 204 lojas em todo o país e investiram R\$600.000.000,00 em 2001 (equivalente a aproximadamente US\$166,000,000.00).

A Renner e a Riachuelo quase dobraram as vendas nesse período. A estimativa da Revista Exame (2002 b) indica que as vendas da C\&A (a maior das três), no mesmo prazo, cresceram 20\%. Ambas as empresas investem forte na publicidade, de acordo com estratégias de massificação da moda, captando clientes do pequeno varejo formal e do pulverizado informal (somando-se, as três investiram $\mathrm{R} \$ 60$ milhões em 2001, de acordo com o jornal especializado Meio e Mensagem, apud Exame 2002 b) desde contratos com modelos brasileiras(os) de renome internacional e artistas em auge na televisão, até patrocínios para concursos de modelos e desfiles no maior evento de moda no Brasil, São Paulo Fashion Week.

Estes varejistas especializados, com nome de marca, procuram uma maior integração com os fornecedores, auxiliando-os na análise de conceitos e tendências, na definição de nichos, preços e serviços ao cliente, desenvolvimento de sistemas de logística e distribuição. 
As atividades de coordenação da produção, logística e gestão da cadeia de fornecimentos são cada vez mais deixadas para empresas fornecedoras full-package. Este processo de reestruturação passa pela redução do número de fornecedores e o estreitamento das relações interempresariais.

Grandes redes de varejo de massa (hipermercados e cadeias de desconto) como Walmart e Carrefour, têm atuado com marcas próprias ou "genéricas" de vestuário padrão, baseadas em altos volumes e baixos preços. Esta tendência crescente favorece o fornecimento feito por empresas que fabricam produtos padronizados em grande escala e baixo custo, entre as quais encontram-se grandes e pequenas empresas. A organização da cadeia produtiva fica sob responsabilidade dos varejistas ou de fornecedores de primeira linha, que podem ser empresas produtoras ou brokers agenciadores de produção.

A lógica de operação é distinta dos Varejistas com Marca e dos Comercializadores com Marca, no caso destes últimos, como seu ativo maior está no design e no valor da marca, recorrem a uma base de fornecedores mais diversa e com frequência mais especializada, que dá oportunidade a relações menos precárias na cadeia produtiva.

Para as demais empresas que não são líderes nestas três categorias, trata-se de um processo de alinhamento dentro das cadeias produtivas e a ocupação de espaços que estão sendo criados pela desverticalização das empresas líderes, pela definição dos nichos de mercado, especialização nas competências essenciais e na própria dinâmica evolutiva das empresas no conjunto da indústria. 


\subsubsection{Trajetórias das empresas brasileiras sob a abordagem de Progressão Industrial}

Na continuação utilizar-se-ão os conceitos de Progressão Industrial e de Modernização Industrial para descrever, sinteticamente, alguns casos representativos de trajetórias de empresas brasileiras.

\subsubsection{Empresas produtoras de vestuário}

A empresas produtoras com marca foram, inicialmente, produtoras integradas OEM (têxtil-confecção), que alcançaram grande porte e consolidaram suas marcas pela qualidade. Para fazer frente aos desafios da competição, algumas investiram primeiro no varejo próprio e/ou na franquia de suas marcas, como é o caso da Hering. Num segundo momento, desverticalizaram a maior parte de sua produção, focalizando em novas competências essenciais como o design, ferramenta para a consolidação de novas marcas e dos canais de varejo especializado. Algumas dessas empresas atuam ainda como fornecedores OEM, para grandes clientes de produtos padrão, como é o caso de várias grande produtoras de jeans.

Fig. 5.10 -

Produtoras de vestuário com Marca integradas verticalmente

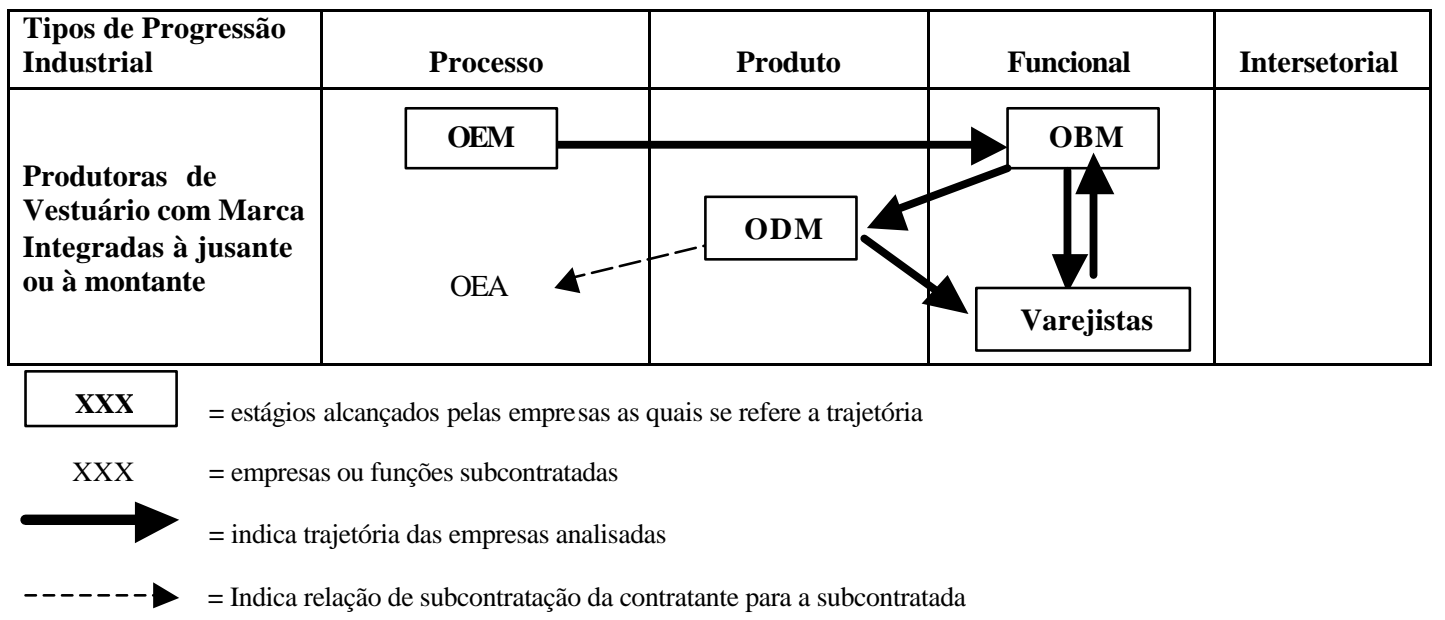


Empresas menores, que começaram como confecções locais, apostaram no design e na criação de marcas originais, produzindo para nichos específicos um varejo especializado e para lojas multimarcas, eventualmente estabelecendo lojas próprias. São hoje marcas reconhecidas com alto conteúdo de design, principalmente no setor de moda feminina. Há, entre elas, empresas que já alcançam renome nacional e outras que servem nichos localizados nas grandes cidades brasileiras. Sua trajetória representa-se, a seguir, na figura 5.11.

Fig. 5.11 -

Produtores de vestuário com Marca

\begin{tabular}{|lc|c|c|c|}
\hline $\begin{array}{l}\text { Tipos de Progressão } \\
\text { Industrial }\end{array}$ & Processo & Produto & Funcional & Intersetorial \\
\hline $\begin{array}{l}\text { Confecções } \\
\text { Produtoras de } \\
\text { vestuário com Marca } \\
\text { Full-package }\end{array}$ & OEM & & & \\
& OEA & & & \\
\hline
\end{tabular}

Fonte: Elaboração própria.

A figura 5.12 representa os fornecedores do comércio de "Boutiques" para todo o país, aglomerados em centros produtores, como o Bom Retiro, em São Paulo, e em outras cidades com produção especializada. Estas empresas funcionam como fornecedoras de pacotes completos com design - ODM, para lojas que podem pedir para etiquetar, com a sua marca, linhas completas. Os produtos oferecidos por elas, além de concorrentes, são muitas vezes complementares e um comprador pode completar seu mix em vários fornecedores.

Alguns eventualmente vendem os produtos com suas etiquetas e são rápidos, eficientes e recriadores das tendências de moda lançadas nas passarelas, adaptado-as ao consumidor comum e à produção de escala, utilizando materiais menos nobres para, finalmente, obter menores custos de produção. Seu processo de comercialização é controlado por eles no atacado, e geralmente vêm para negociar os clientes varejistas que, em geral, são 
pequenos. A produção é, em grande parte, terceirizada, suas competências estão no design e na capacidade de resposta rápida, precisam de capital de giro para produzir e eventualmente de crédito para financiar os clientes.

Fig. 5.12 -

Fornecedores de vestuário ODM atacadistas

\begin{tabular}{|l|c|c|c|c|}
$\begin{array}{l}\text { Tipos de Progressão } \\
\text { Industrial }\end{array}$ & Processo & Produto & Funcional & Intersetorial \\
\hline $\begin{array}{l}\text { Confecções } \\
\text { Produtoras de } \\
\text { Vestuário com ou } \\
\text { sem Marca } \\
\text { Full-pacakge }\end{array}$ & OEM & & ODM & \\
\hline
\end{tabular}

Fonte: Elaboração própria.

Há ainda aqueles fornecedores de pacotes completos - OEM e maquiladoras - OEA que desenvolveram capacidades no desenvolvimento de produtos. Assim como os anteriores, são capazes de interpretar as tendências da moda e de oferecer respostas rápidas e baratas. A diferença, em relação aos anteriores, é que negociam cada vez mais com grandes clientes, muitas vezes convertendo-se em fornecedores exclusivos, interpretando e respondendo aos parâmetros de nicho de mercado e preços estabelecidos por eles. Seus produtos são vendidos com as marcas privadas das redes de comercialização de seus clientes. Sua trajetória é sintetizada na figura 5.13.

Fig. 5.13 -

Produtores de vestuário ODM

\begin{tabular}{|c|c|c|c|c|}
\hline $\begin{array}{l}\text { Tipos de Progressão } \\
\text { Industrial }\end{array}$ & Processo & Produto & Funcional & Intersetorial \\
\hline $\begin{array}{l}\text { Confecções } \\
\text { produtoras de } \\
\text { vestuáriofull- } \\
\text { package com } \\
\text { competências de } \\
\text { design }\end{array}$ & OEM & & & \\
\hline
\end{tabular}


Por último, temos os fornecedores OEM e OEA. Aqui a concorrência é acirrada e precarizante e se dá em grande parte do país. A cadeia de subcontratação como, em toda a CPTV, porém de forma mais de acentuada, alcança seus maiores índices sendo comum o trabalho domiciliar e em cooperativas de costureiras. A concorrência por custo leva à mais baixa remuneração de uma MDO menos habilidosa e organizada.

Ainda neste item, ressalta-se o papel de algumas Produtoras de Insumos de Marca, grandes e médias tecelagens, que junto às produtoras de fibras, desenvolvem matériasprimas de qualidade e transmitem o valor da sua marca àquelas empresas produtoras de vestuário que os utilizam na confecção de suas roupas. No caso das produtoras de fibras, chegam a coordenar/financiar campanhas junto a designers e tecelagens e, com isso, acabam alavancando suas vendas e as dos parceiros.

Neste caso, projeto e desenvolvimento de produtos são atividades técnicas visando o desenvolvimento de aplicações e adaptações das inovações tecnológicas dos departamentos de P\&D das matrizes. Diferente do design de moda, que está mais ligado à estética e ao marketing.

A coordenação é, neste caso, partilhada pelos designers e varejistas, de um lado, e pelas fornecedoras de fibras e produtos para o acabamento, do outro. No meio, algumas tecelagens com capacidades técnicas e produtivas, muitas vezes certificadas, produzem os tecidos desejados pelos estilistas e consomem as matérias-primas dos produtores de fibras, fechando o ciclo mais virtuoso da CPTV, na qual todos os elos têm reconhecimento e agregam valor pela marca. Além do valor da marca, este tipo de cooperação possibilita uma eficiência coletiva que gera competitividade da CPTV como um todo. 


\subsubsection{Trajetória das empresas Comercializadoras com Marcas}

As empresas líderes Comercializadoras com Marca, como já descrito, têm pouca ou nenhuma atuação na produção, a não ser a prototipagem e/ou produções especiais, cada vez mais terceirizada em empresas do tipo OEM ou OEA.

Inicialmente estas empresas têm como competências o design e nele focalizam esforços, assim como nas funções de marketing e varejo/distribuição e a coordenação da cadeia de fornecedores (Suply Chain Management - SCM).

No Brasil, estas empresas ainda representam uma mínima percentagem do volume comercializado nacionalmente, como também no exterior, porém sua importância radica na visibilidade dada à indústria, através de eventos como o São Paulo Fashion Week SPFW e de estratégias de marketing e campanhas publicitárias, baseadas em comportamento e estilo de vida, que além de apontar tendências para o resto dos segmentos seguidores, servem também como difusores das inovações tecnológicas e de novos materiais lançados pelos fornecedores de insumos.

São estas parcerias a combinação que, junto com os investimentos em modernização, tem possibilitado o reflorescimento da indústria do vestuário nacional.

As empresas e suas marcas fashion estão consolidando-se no Brasil, algumas delas começam a ter presença no exterior, entre elas marcas de moda praia, feminina e jeans. A comercialização de varejo é realizada por meio de redes próprias e licenciadas quando no Brasil.

No exterior, algumas das marcas mais tradicionais tentam consolidar redes de distribuição através de redes especializadas de vestuário de moda, nas melhores redes de lojas de departamento e ainda em showrooms próprios. Os mais novos estilistas e suas marcas investem e participam de desfiles, badalados eventos publicitários e estão nos 
editoriais de revistas internacionais. Suas trajetórias são sintetizadas na figura 5.14 a seguir.

Fig. 5.14 Comercializadoras com Marca

\begin{tabular}{|ll|c|c|c|}
\hline $\begin{array}{l}\text { Tipos de Progressão } \\
\text { Industrial }\end{array}$ & Processo & Produto & & Funcional \\
\hline $\begin{array}{l}\text { Comercializadores } \\
\text { com Marca baseados } \\
\text { em design }\end{array}$ & OEA & ODM & OBM \\
& OEM & & $\begin{array}{l}\text { Varejistas } \\
\text { Exclusivos }\end{array}$ & \\
\hline
\end{tabular}

Fonte: Elaboração própria.

\subsubsection{Trajetória dos Varejistas}

No Brasil as maiores lojas de departamentos (Mesbla e Mappin) faliram na década passada. Na atualidade o que encontramos são redes de lojas de varejo especializado em roupas com Marca e grandes varejistas do tipo "hipermercados", tanto nacionais quanto de capital estrangeiro.

No Primeiro caso estão os Varejistas com Marca, alguns dos quais se iniciaram como produtores OEM, que desenvolveram o seu próprio varejo, e outros que começaram como varejistas, e estão tratando de consolidar suas marcas.

Atualmente a Riachuelo, a Renner e a C\&A são as que se destacam mais e que investem mais em moda e publicidade, porém há outras redes especializadas mais tradicionais.

Suas atividades focalizam-se no desenvolvimento e na consolidação de marcas, a coordenação da cadeia de fornecimentos ( $S C M)$, gestão de estoques e a logística; quase toda sua produção é terceirizada. 
Dentro destas, uma função nova que se destaca é a dos gerentes e coordenadores de produto, encarregados de interpretar as tendências, coordenam a criação e a produção junto aos subcontratados, os quais muitas vezes são fornecedores full-package OEM ou ODM.

Fig. 5.15 Varejistas com Marca

\begin{tabular}{|c|c|c|c|c|}
\hline $\begin{array}{l}\text { Tipos de } \\
\text { Progressão } \\
\text { Industrial }\end{array}$ & Processo & Produto & Funcional & Intersetorial \\
\hline $\begin{array}{l}\text { Trajetória dos } \\
\text { Varejistas com }\end{array}$ & OEM & ODM & Varejistas & \\
\hline & OEA & & $\begin{array}{l}\text { Varejistas } \\
\text { com Marca }\end{array}$ & \\
\hline
\end{tabular}

Os grandes varejistas utilizam as estratégias do varejo cedendo lugar para marcas de consumo popular e criando marcas próprias (private labels), as competências de gestão da cadeia de fornecedores OEM têm aqui um papel fundamental. Sua trajetória e estratégias no comércio de vestuário são resumidas na figura 5.16, a seguir.

Fig. $5.16-$

Grandes Varejistas

\begin{tabular}{|c|c|c|c|c|}
\hline $\begin{array}{l}\text { Tipos de } \\
\text { Progressão } \\
\text { Industrial }\end{array}$ & Processo & Produto & Funcional & Intersetorial \\
\hline \multirow{3}{*}{$\begin{array}{l}\text { Trajetória dos } \\
\text { Grandes } \\
\text { Varejistas }\end{array}$} & \multirow{3}{*}{$\begin{array}{l}\text { OEA } \\
\text { OEM }\end{array}$} & & $\begin{array}{c}\text { Grandes } \\
\text { Varejistas }\end{array}$ & \\
\hline & & ODM & SCM & \\
\hline & & & OBM & \\
\hline
\end{tabular}

Fonte: Elaboração própria. 
No caso dos Varejistas de Marca, é interessante analisar a importância que o crédito assumiu, podendo representar a diferença entre o lucro e o prejuízo no balanço (Cotias, 2003). Há a estratégia de cartões 'private label” pela qual "muitas varejistas trabalham na venda mercantil sem lucro e realizam o resultado na parte financeira" (Serrentino, in Cotias, 2003 a) com crédito Direto ao Consumidor - CDC.

Algumas redes vendem a carteira para os bancos, que repassam as receitas de intermediação para o varejo; outras, como a C\&A, obtiveram competência tal que o negócio evoluiu para outro. Esta empresa montou um banco, em fevereiro de 2001, o Ibibank, que segundo dados do Banco Central, no primeiro ano teve uma carteira de R \$56,3 milhões e em 2002 chegou a R \$ 219,4 milhões. Em financeiras instaladas dentro das 80 lojas C\&A, ou em agências independentes, a bandeira holandesa oferece produtos como seguros, títulos de capitalização e fundos de investimento, produtos bem diferentes das roupas próximas.

A adoção de ferramentas de avaliação de risco mais modernas influiu diretamente no desempenho da Guararapes confecções/Riachuelo, com uma carteira de R \$260 milhões, e lucro liquido de $R \$ 92,1$ milhões (52\% a mais do que em 2001). Segundo executivos da empresa, a Riachuelo não pretende virar banco, mais em suas lojas já é possível contratar seguros residenciais, de desemprego ou assistência automotiva (Cotias, 2003 b).

As grandes redes de varejo têm também estratégias similares de fidelização de clientes e de crédito. Nesse caso, a figura 5.17 representa a trajetória que, se não significa uma mudança de setor é, com certeza, um avanço funcional que utiliza ferramentas de outros setores. 
Fig. 5.17 Varejistas com Marca com estratégias de serviços financeiros

\begin{tabular}{|l|l|l|l|l|}
\hline \multicolumn{1}{|c|}{$\begin{array}{c}\text { Tipos de Progressão } \\
\text { Industrial }\end{array}$} & Processo & Produto & Funcional & Intersetorial \\
\hline $\begin{array}{l}\text { Novos serviços } \\
\text { financeiros dos } \\
\text { Varejistas }\end{array}$ & & & Varejistas & \\
\hline
\end{tabular}

Fonte: Elaboração própria.

\subsubsection{Aprendizado e ganho de competências no processo de Progressão Industrial} das Cadeias de Produção Têxtil-Vestuário - CPTV

Da mesma forma que com as empresas da IHMR, a figura 5.18 mostra, simplificadamente, as atividades que as empresas brasileiras desenvolveram, na década de 90 e que lhes permitem desenhar as estratégias de internacionalização em nichos de produtos com marcas.

Fig. $5.18-$

Competências das empresas brasileiras coletivamente antes e depois da reestruturação produtiva da década de 1990

\begin{tabular}{|c|c|c|c|c|c|c|c|c|}
\hline Atividades & $\begin{array}{l}\text { Fiação } \\
\text { e tecela- } \\
\text { gem }\end{array}$ & $\begin{array}{l}\text { Acaba - } \\
\text { mento }\end{array}$ & Design & $\begin{array}{l}\text { Confecção/ } \\
\text { malharias }\end{array}$ & $\begin{array}{l}\text { Confecção } \\
\text { de pacotes } \\
\text { completos }\end{array}$ & $\begin{array}{c}\text { Gestão da } \\
\text { cadeia de } \\
\text { fornecedores }\end{array}$ & $\begin{array}{l}\text { Logística e } \\
\text { distribuição }\end{array}$ & $\begin{array}{c}\text { Comercialização } \\
\text { de produtos com } \\
\text { marca original }\end{array}$ \\
\hline $\begin{array}{l}\text { Estratégias prévias } \\
\text { a década de } 1990 \\
\text { para o mercado } \\
\text { interno }\end{array}$ & & & 1 & & & & & \\
\hline $\begin{array}{l}\text { Competências } \\
\text { desenvolvidas no } \\
\text { mercado interno } \\
\text { que possibilitam a } \\
\text { internacionalização } \\
2001 / 2002\end{array}$ & & & & & & & & \\
\hline
\end{tabular}

' = Competências parciais

$D$ = Competências parciais em processo de aperfeiçoamento

Fonte: Elaboração própria. 
A figura anterior mostra dois momentos: o fato de, coletivamente, as empresas apresentarem uma melhoria e complementação de capacidades não quer dizer que algumas delas não tenham sofrido um perda de capacidades ou downgrading, inclusive, como já mencionado, muitas desapareceram aqui. Porém, em suma há, um ganho de competências nas CPTVs brasileiras, ou seja, uma Progressão Industrial.

\subsection{Comparação, análise e conclusões a respeito das Cadeias Produtivas Têxtil-Vestuário - CPTV em ambos os países \\ 5.3.1 Produtos, mercado e investimento internacional das empresas hondurenhas e brasileiras}

Aqui tratar-se-á de sintetizar, comparativamente, o que foi exposto nos itens anteriores.

A primeira grande diferença é o destino dos produtos de exportação de vestuário. No caso do Brasil as exportações para a Argentina e o MERCOSUL, Europa e Ásia, são destinos das importações, embora os Estados Unidos e o NAFTA tenham tido um crescimento importante nas exportações brasileiras recentemente. No caso de Honduras, mais do $90 \%$ das exportações de vestuário de Honduras vão para os Estados Unidos.

Em relação aos produtos exportados, os hondurenhos são menos variados e em sua maioria, básicos, destacando-se sweaters, camisas de malha, sutiãs, camisetas, calças roupa íntima masculina e feminina em geral, já nas exportações brasileiras para os Estados Unidos, apesar da coincidência de camisas de malha, camisetas e calças entre os principais produtos de exportação, também entre eles estão paletós e ternos, roupões, felpudos e tecidos tintos. Mesmo não sendo representativas no volume, as exportações de vestuário de moda brasileiras com marcas originais estão alcançando algumas vitrines nos principais centros urbanos globais e nos editoriais nas revistas do setor. 
Quanto ao investimento estrangeiro, em Honduras este é liderado por empresas estadunidenses: principalmente produtores de marcas, mas também os comercializadores e varejistas. Em segundo lugar vêm os investimentos de capital asiático.

No Brasil, ao contrário, o investimento externo mais representativo está no início das cadeias na produção de fibras, e se dilui nos estágios seguintes até a comercialização. Onde estão presentes as produtoras e varejistas dos Estados Unidos, há também um grande percentual de investimento europeu, enquanto o investimento asiático, no setor, é bem menor. Ademais, a maioria do investimento externo tem, como finalidade, obter fatias do mercado interno brasileiro mais do que a exportação.

As exportações brasileiras, tanto de empresas nacionais como de empresas estrangeiras são, em todos os casos, muito pequenas, enquanto a produção das maquiladoras hondurenhas é, pelo contrário, dedicada à exportação.

\subsubsection{Estrutura e governance das cadeias em que estão inseridas as maquiladoras hondurenhas e as empresas brasileiras}

No caso hondurenho, está claro que a governance pertence às empresas produtoras, varejistas e comercializadoras estadunidenses, que têm o domínio dos canais de comercialização e o contato com o mercado.

No caso brasileiro, as empresas para quem a exportação é um segundo e, à vezes, opcional mercado, já detêm, no competitivo mercado brasileiro, as competências ligadas à comercialização: marketing, varejo, desenvolvimento de marcas e design de produtos.

As governances no mercado exterior ainda são das empresas, porém as marcas brasileiras estão chegando mais perto do consumidor final através dos varejistas 
estadunidenses e europeus, de showrooms e/ou lojas próprias ou pela mídia. A soma desses fatores podem contribuir, de forma importante, para a inserção da "marca-Brasil" no inconsciente do consumidor nesses países.

\subsubsection{Considerações em relação ao progresso industrial das empresas hondurenhas e brasileiras nas Cadeias Produtivas Têxtil-Vestuário - CPTV}

A análise dos casos das empresas "maquiladoras" hondurenhas mostra que, antes deste sistema preferencial tarifário, operavam verticalmente e detinham as competências e o controle de todas as etapas produtivas, sendo líderes no âmbito nacional e ainda tinham alguma participação nas exportações para o mercado estadunidense, desde a década de 70, inclusive com o drawback.

Ao ingressarem como maquiladoras nas CPTV dirigidas ao mercado americano, é pertinente afirmar que estas empresas sofreram um downgrading funcional, assim como de processos e de produto (que pode ser visto como especialização, de outro ponto de vista), ao deixar de lado as funções finais da comercialização e suas marcas próprias originais, passando de posições OEM e OBM para OEA.

Se considera-se a expansão de suas atividades comerciais (mesmo como fornecedoras de maquila), do nível nacional para o nível internacional, e que isto levou a um aprendizado de novas competências na gestão e negociação (incluindo as atividades de pressão (lobbies) nas esferas governamentais nacional e no contexto internacional), pode-se afirmar que houve uma progressão funcional.

O que não significa que esta ampliação de mercado lhes confira uma quota de governance, na cadeia, suficiente para obter a liderança ou mesmo garantir a permanência como fornecedoras, porém são condições sine qua non. 
Até o presente, sua competitividade têm sido garantida pelos baixos salários e moeda nacional, pelos acordos comerciais bilaterais e regionais, assim como de "ajuda" assinados com os Estados Unidos, os quais têm contrapartidas políticas.

No entanto, percebe-se nas trajetórias das maquiladoras, que houve também um aprendizado e ganho de competências para a coordenação de fornecedores, ou seja novas maquiladoras, nos níveis ou tarefas que elas deixam para trás ou naquelas em que eventualmente há maior demanda de capacidade, tornado-se coordenadores de fornecedores de segundo nível, subcontratando atividades como a costura ou outras complementares.

A figura 5.9 apresenta os ganhos e as perdas de competências na trajetória das empresas hondurenhas, inicialmente mostra as atividades realizadas pelas empresas nacionais antes da maquila, no segundo momento: o downgrading realizado para a inserção nas CPTV para o mercado dos Estados Unidos, como maquilad

oras e, por último, o novo processo de progressão, pelo qual pretendem aumentar ou sustentar sua competitividade no cenário vindouro.

Existem também eventuais coordenações entre os principais grupos da indústria têxtil e da confecção na base de forças-tarefas para o cumprimento dos pedidos ${ }^{60}$.

Por causa da carência de um tecido industrial denso e diverso, os poucos grupos com capital suficiente têm de realizar investimentos em atividades complementares, o que leva à integração vertical.

\footnotetext{
${ }^{60}$ No caso das empresas de confecção, a subcontratação da confecção (uma das suas core competences) se realiza quando há falta de capacidade. No segundo caso, quando sua competência essencial está no setor têxtil, a subcontratação da confecção se dá a partir do momento em que começa a fornecer pacotes completos.
} 
Alguns investimentos geram desmembramentos de capital que passam a ser gerenciados por indivíduos das novas gerações familiares. Isto pode incluir as joint-ventures com as empresas estrangeiras contratantes ou seus fornecedores globais, que são freqüentes, principalmente, no início de novas operações.

Em outros casos, investimentos internacionais de outras origens chegam para preencher os vácuos, é o caso do grupo taiwanês analisado (na estamparia) e do grupo de capital estadunidense-guatemalteco na lavanderia industrial (Tabela 2.10).

Já no caso do Brasil, com um tecido industrial muito mais diverso e complexo, o extenso mercado potencializou o crescimento e desenvolvimento completo de todas as atividades produtivas, desde a produção de fibras naturais e químicas até a consolidação de marcas e redes de varejo modernas.

Por isso, além de existirem empresas e grandes grupos verticalizados (em processo de desverticalização e/ou especialização alguns, principalmente terceirizando a produção) as empresas complementam as suas competências. Assim, encontramos empresas em todas as posições da tipologia de Modernização Industrial e empresas líderes com as caraterísticas das empresas que lideram as cadeias globais, no nível de produtores, comercializadores e varejistas.

O fato de todos os elos da produção estarem localizados no país, e principalmente a disputa pelo mercado, faz necessárias estratégias cooperativas que fortaleçam a eficiência coletiva das cadeias e grupos empresariais. O poder dos produtores (tanto fibras como tecidos e mesmo das grandes confecções) já foi contestado pelo varejo e pelas atividades mais ligadas à comercialização.

Neste segmento há empresas com competências similares às dos países e mercados desenvolvidos. A inserção de algumas empresas com marcas e o sucesso dos designers 
nacionais no exterior, são prova da capacidade de comercializar os produtos brasileiros em nichos de mercado mais lucrativos e com maior relação com o consumidor final.

A abertura comercial atingiu as indústrias têxtil e de vestuário do Brasil, provocando a reestruturação de todos os elos produtivos, que atuavam independentemente e com frequiência conflitivamente, propiciando a estruturação de novos arranjos produtivos, com uma percepção de cadeias produtivas e de agregação de valor que precisam cooperar e coordenar atividades para obter a eficiência produtiva coletiva.

A abertura comercial e a entrada de competidores provocou trajetórias aceleradas de aprendizado e de Progressão Industrial em todos os níveis: de processos, produtos e funcional; assim como a definição e consolidação de posições de Modernização Industrial, havendo empresas que atuam como OEA, OEM, ODM, OMB e GB.

Assim, as CPTV brasileiras têm características das cadeias internacionais, com todos os componentes contidos na geografia nacional. Podendo competir internacionalmente, em todos os níveis, como fornecedores ou como comercializadores de produtos acabados com marcas originais.

Nas trajetórias das empresas de ambos os países, é necessário considerar os entornos institucionais, a dimensão dos mercados, as estratégias de Industrialização Por Substituição de Importações - ISI, os mecanismos de proteção dos respectivos mercados internos, as preferências e ou barreiras comerciais que enfrentam para as exportações e, a vocação ou necessidade dos empresários para exportar nos respectivos contextos.

O maior desenvolvimento brasileiro e uma demanda maior e de maior poder aquisitivo possibilitaram a existência de uma MDO mais qualificada ou, pelo menos, mais diversa no ensino superior, especificamente nos cursos relativos à engenharia têxtil e ao design de modas, cursos até hoje não existentes em Honduras, onde a empresa privada teve que 
suprir as carências com profissionais estrangeiros ou investindo em capacitação de nacionais no exterior.

O relacionamento com as empresas estrangeiras possibilita um aprendizado, porém este não vai além dos conhecimentos necessários para a produção e a gestão da cadeia de fornecedores ou daquelas funções que as empresas líderes desejam repassar, ao contrário, há barreiras para uma abertura comercial maior por empresas que subcontratam operações em Honduras e na região.

Quanto à MDO, esta é uma indústria que, apesar dos avanços tecnológicos, continua sendo extensiva em trabalho humano nas etapas de costura, embalagem, supervisão etc. Neste quesito, ambos os países têm grandes carências de emprego e renda para grande parte da população desempregada, o que leva à informalização e precarização das relações de trabalho.

A força de trabalho, em ambos os casos, tem demonstrado sua capacidade de aprendizado e produtividade, quando há oportunidade do emprego ou de capacitação formal.

A criatividade dos designers e estilistas precisa do suporte e da parceria de cadeias produtivas, em que a cooperação impere desde os produtores de fibras até os comercializadores; isto tem sido demonstrado no Brasil, onde as marcas internacionais têm que disputar espaços com marcas fortes e criativas neste mercado, enquanto que o mercado das maquiladoras hondurenhas não o permite.

As incursões de marcas brasileiras nos mercados dos países desenvolvidos, seja nos desfiles, seja como fornecedores com marcas nas lojas de departamentos, ou com lojas e showrooms nos centros de moda, são uma mostra de que estas trajetórias possibilitam uma entrada diferente ao mercado internacional, e que é a estratégia que compensa as barreiras tarifárias, a distância e os altos custos. Esta estratégia, provavelmente, terá 
melhores resultados num futuro mercado livre. Uma vez mais as barreiras comerciais provaram ser um estímulo para o desenvolvimento de alternativas à procura de novos nichos de mercado e desenvolvimento de competências.

No caso de Honduras, as preferências tarifárias e a competição por custo, somadas ao exposto anteriormente, limitaram essas possibilidades, embora há exceçõe s que estejam procurando prepara-se para o futuro cada vez mais competitivo. No próximo item resume -se esta comparação. 


\subsubsection{Síntese das Trajetórias de Progressão Industrial das empresas das CPTV de Honduras e do Brasil}

\section{Honduras}

- As empresas da IHMR são extremamente dependentes de insumos e matérias-primas importadas, controladas pelas empresas líderes.

- Algumas empresas maquiladoras hondurenhas têm relações comerciais estáveis com seus clientes estrangeiros, por períodos aproximados de até duas décadas.

- Nestas cadeias, as relações interempresariais têm maior interferência e influência de políticas protecionistas dos governos dos países industrializados, por meio de acordos comerciais, bi e multilaterais, procurando proteger suas empresas e postos de trabalho.

\section{Brasil}

- Com as devidas ressalvas, nas CPTV brasileiras há suficiência de insumos básicos na maioria dos elos, embora as maiores inovações e especialidades ainda sejam importadas.

- A maioria das empresas brasileiras que começam a exportar ainda estão no início do estabelecimento de relações comerciais.

- As relações inter-empresariais nas CPTV brasileiras dependem mais de negociação e cooperação entre empresas nacionais ou estrangeiras atuando no Brasil, regidas todas pelo mesmo marco jurídico, enfrentado coletivamente as barreiras para exportação. 
- O ambiente institucional e o tecido industrial hondurenhos são limitados no que se refere a Centros de Formação e Capacitação Profissional, P\&D, etc., o que restringe as possibilidades de um aprendizado industrial e do desenvolvimento de novas competências localmente, ficando na dependência das funções que as empresas estrangeiras queiram repassar ou em altos investimentos de capacitação no exterior.

- De maneira simplista, pode-se dizer que as empresas da maquila hondurenha ingressaram nas CPTV internacionais pela via baixa - lowroad, baseando-se em atividades intensivas em MDO pouco qualificada e remunerada para produção de produtos padrão, que demandam pouca tecnologia.

- As empresas tradicionais hondurenhas que investiram na maquila inicialmente sofreram um downgrading funcional, de processos e de produtos para poder se encaixar nelas; posteriormente, para manter sua competitividade e permanecer nessas cadeias, estas empresas estão passando por um processo de Progressão Industrial, que lhes possibilite executar as atividades requeridas e permitidas pelas empresas líderes.
- No Brasil, um ambiente institucional variado, com centros de ensino e de $\mathrm{P} \& \mathrm{D}$ diverso, permite $\mathrm{O}$ desenvolvimento de competências locais e o fortalecimento das CPTV com liderança de empresas nacionais.

- Do mesmo modo, pode-se dizer que algumas das empresas brasileiras estão tentando obter posições pela via alta - highroad, mais lucrativa e que requer especialização da MDO e diversidade de competências, tecnologia e capital, para oferecer produtos de maior qualidade $\mathrm{e}$ atributos para o consumidor.

- As empresas brasileiras, na ultima década, tiveram que reestruturar-se para manter sua competitividade no mercado interno, o que lhes possibilitou adquirir competências que lhes garantem melhores posições nas CPTV internacionais e a liderança em cadeias brasileiras que atuam no mercado nacional e internacional, principalmente nos nichos onde o valor radic a na marca e no design. 
- A IHMR hondurenha ainda é muito especializada no elo da confecção e realiza esforços para sua diversificação e integração de atividades que agreguem maior valor.

- A maioria das empresas da maquila hondurenhas têm grande capacidade de escala de produção, o que lhes confere produtividade e baixos custos.

- As governance é polarizada nos elos à jusante da CPTV e é detida pelas empresas estrangeiras. As empresas nacionais realizam esforços para alcançar posições de coordenação de fornecedores locais de outras atividades subcontratadas num segundo nível.

- Ir além das funções e atividades solicitadas pelas empresas líderes estrangeiras que detêm a governance requer esforço adicional, às vezes conflitivo, para vencer as barreiras le vantadas nas próprias cadeias.
- O parque industrial brasileiro, mais rico, permite cadeias nacionais completas, que podem oferecer um mix de produtos mais diversificado e uma flexibilidade produtiva maior.

- No elo da confecção, o porte das empresas (com raras exceções) da CPTV brasileira é de pequeno a médio, assim como sua escala de produção.

- A governance no Brasil é, com freqüência, compartilhada e/ou negociada entre as empresas à montante e à jusante, sendo o elo da confecção o mais fraco e o elo da comercialização cada vez mais poderoso.

- $\mathrm{O}$ fato de empresas nacionais deterem posições de liderança facilita o traslado de competências para as empresas fornecedoras nacionais dentro da cadeia, o que é facilitado até por fatores culturais e de aglomeração geográfica. 
- A produtividade da MDO ao nível de chão de fábrica, assim como competências ao nível de engenharia e gestão da produção, parecem ser alguns dos ganhos da participação nas CPTV internacionais.

A demanda de pessoal capacitado de nível superior tem influenciado dinamicamente o ensino universitário, principalmente nas áreas de engenharia industrial e gestão da produção.
- No Brasil também a demanda de pessoal capacitado aumenta, principalmente nas áreas que mais agregam valor ao nível do design e do marketing. 


\subsection{Modelo revisitado nas Cadeias Produtivas Têxtil-Vestuário}

\subsubsection{As trajetórias de Modernização Industrial e de Progressão Industrial baseadas nos casos analisados}

A análise de ambas as trajetórias mostrou que existem alternativas para a Progressão Industrial e, como no caso das empresas brasileiras, quando um país tem o grau de desenvolvimento industrial e o mercado que este país possuía, pode concorrer com as empresas dos países desenvolvidos em nichos de mercado mais avançados e lucrativos na competição global. As trajetórias dos dois países são sintetizadas na figura 5.16 a seguir.

Fig. 5.19 -Síntese das Trajetórias de Modernização Industrial das empresas de Honduras e Brasil

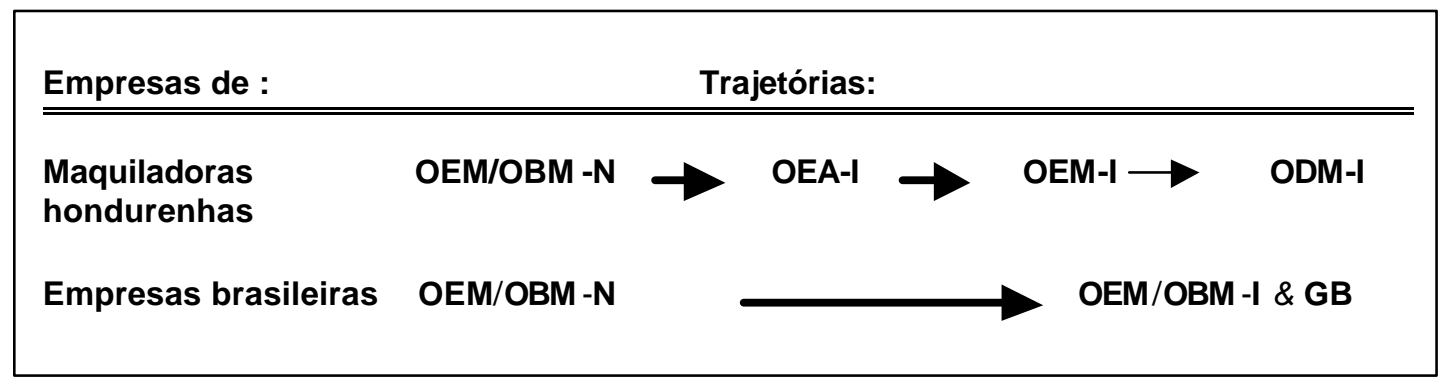

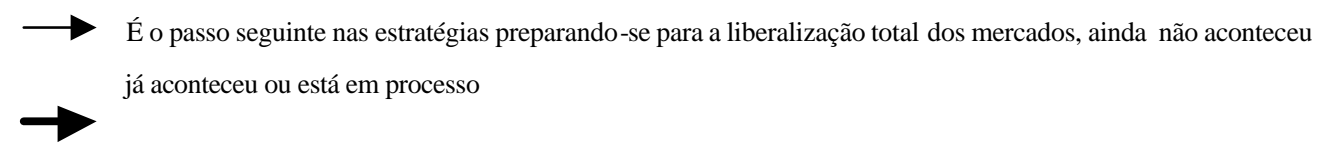

Fonte: Elaboração própria.

Essa configuração das cadeias em que estão inseridas as empresas analisadas em Honduras e Brasil, apresentados acima, nos permite formular um modelo mais aprofundado das trajetórias dos países em desenvolvimento inseridos nos modelos de exportação através do sistema preferencial de maquilas, como é o caso hondurenho e, por outro lado, modelar as trajetórias das empresas brasileiras que estão apostando em 
competências ligadas ao consumidor final, concorrendo com as empresas globais nestes elos das cadeia de agregação de valor e liderando suas próprias cadeias de fornecimento.

O modelo revisto das trajetórias de Modernização e Progressão Industrial nas CPTV globais apresenta-se, na figura 5.17 a seguir, em que sua complexidade é o somatório das trajetórias analisadas acima.

Fig. 5.20 - Novo modelo de Trajetórias de Progressão Industrial e Modernização Industrial

\begin{tabular}{|l|l|l|l|l|}
\hline $\begin{array}{c}\text { Tipos de } \\
\text { Progressão } \\
\text { Industrial }\end{array}$ & Processo & Produto & Funcional & Intersetorial \\
\hline $\begin{array}{l}\text { Estágios de } \\
\text { Modernização } \\
\begin{array}{l}\text { Industrial e } \\
\text { trajetórias das } \\
\text { empresa dos } \\
\text { países em } \\
\text { desenvolvimento }\end{array}\end{array} \quad$ OEM-I
\end{tabular}

N: Nacional.

I: Internacional, em alguns casos esta trajetória pode significar regional, como é o caso de algumas cadeias/marcas asiáticas, ou brasileiras com influência no MERCOSUL.

*OBM Incluí Brandnamed Manufacturers.

**GB: Global Buyers: Brandnamed Marketers, Brandnamed Retailers \& Supply Chain Coordinators

\footnotetext{
(Brokers / agentes comerciais).

É a trajetória do modelo original.

São trajetórias que muitas das maquiladoras seguiram antes de inserir-se nas cadeias internacionais em países como Honduras ou da Bacia do Caribe.

Trajetórias que indicam downgrading ou integração para trás.

Trajetórias das empresa brasileiras que estão inseridas nas cadeias globais sem passar pelo estágio OEA.

$\longrightarrow$

Esta mudança pode ser realizada também em outros estágios anteriores aos de OBM e GB.
}

Fonte no final

As empresas passam por alguns desses estágios, definindo trajetórias diferentes umas das outras, em diversos momentos; algumas empresas têm produções paralelas para o mercado interno, diferentes das do mercado exterior, reforçando-se mutuamente. 
- São ainda as trajetórias asiáticas de inserção nas cadeias produtivas globais, os únicos modelos possíveis para as empresas dos países menos industrializados alcançarem uma Progressão Industrial, ganhos de poder e competitividade no comércio internacional?

Em termos de aprendizado e aperfeiçoamento industrial, as trajetórias das empresas asiáticas ainda são válidas: a sua capacidade de aprender e superar o mestre, ainda são ícones do progresso industrial. Mas essa capacidade de aprender a fazer melhor os processos e os produtos, assim como a gestão interna e da cadeia de fornecedores, não são suficientes para a competição global.

Os países asiáticos, em relação à maioria dos países latino-americanos, alcançaram patamares de desenvolvimento tecnológico e escalas de produção muito superiores e, ainda com freqüência, em seus locais de produção os salários são tanto ou mais baixos dos que aqui praticados, apesar da elevação. Portanto, custos e produtividade não podem somente dar-se em termos de baixos salários.

Na maioria dos casos, há décadas de atraso nas trajetórias em relação aos pioneiros asiáticos, e hoje eles são competidores de grande peso pela liderança das cadeias globais. 
- Quais são os fatores que influenciam a competitividade das empresas nas cadeias produtivas globais?

Além das funções e competências intrínsecas à própria empresa, a competitividade passa necessariamente pela eficiência coletiva, a qual com a separação das atividades e proc esso produtivos só pode se dar através da coordenação, cooperação e alianças estratégicas.

$\mathrm{O}$ direito de fazer parte de determinadas cadeias requer extremas competitividade e confiabilidade como fornecedor, ou como líder das cadeias, o que requer competênc ias e acesso aos mercados finais ou ser um gerador de inovações tecnológicas permanentemente, nos insumos e/ou nos bens de produção.

A inserção nas cadeias globais é uma oportunidade para as empresas fornecedoras de países em desenvolvimento aumentarem suas exportações e participação no mercado internacional, o qual, na maioria dos casos, é a única forma de sobrevivência, já que seus mercados locais não têm capacidade de demanda. Tanto líderes e fornecedores especializados como fornecedores de MDO, estão cada vez mais interconectados e interdependentes. Porém, a oferta de MDO barata e pouco qualificada é extensa, não uma vantagem competitiva. Portanto, um dos fatores da competitividade é a MDO capacitada em todos os níveis e capaz de aprender rapidamente, o que constitui um desafio para os países em desenvolvimento.

Com as exigências do consumidor final pelo bem estar da força de trabalho e os códigos de conduta, certificações e monitoramentos são ativos intangíveis caríssimos para a imagem das empresas e dos países.

Como o aprendizado nas cadeias é limitado, as empresas dos países em desenvolvimento têm de aprender por si sós ou pela experiência coletiva em mercados internos dinâmicos, e estruturas industriais que cumpram com todos ou a maioria dos requisitos 
de sucesso dos clusters ou distritos industriais. É mais fácil obter sucesso no exterior com uma boa base de fornecedores em todos, ou ao menos, na maioria dos elos que constituem a cadeia, no caso de empresas lideres, ou de forma coletiva, através de consórcios ou outras formas de organização interempresarial.

Obviamente isto se estende para além do pessoal da produção e da gestão empresarial, está claro que empresariado e governos devem agir coordenadamente, o que significa que equipes bem treinadas de estrategistas e negociadores de comércio internacional devem enfrentar as similares de países industrializados, seus principais mercados.

No caso dos países menores, a integração regional ao nível de mercados, de normas, tarifas e, principalmente, nas negociações em bloco, são fatores sumamente importantes, o que incide nas políticas de câmbio e de salários como fatores de competitividade. 
- Quais as possibilidades de alcançar posições de liderança nas cadeias produtivas globais para as empresas dos países em desenvolvimento?

Para obter posições de liderança nas cadeias produtivas globais, é preciso mais do que seguir as trajetórias das empresas asiáticas. Além de entendê-las, é necessário identificar o que é necessário para ultrapassá-las, sob o risco de continuar seguidores para sempre ou sair da competição.

Tanto nos países desenvolvidos como nos emergentes, há trajetórias de empresas ou de países, ou grupos de países, que pela inovação saíram do nada ultrapassando competidores centenários pré-estabelecidos.

Como as CPTV são formadas por diferentes elos, estes podem ser ocupados com sucesso por diferentes tipos de empresas. Já foram discutidas, acima, as limitantes dessas estratégias, mas que pode ser a única para algumas empresas.

A análise das CPTV brasileiras e, principalmente, das empresas produtoras e comercializadoras de marca, mostra que esses possíveis caminhos exigem muito investimento e podem levar até décadas para render os frutos; essas estratégias de investimento em canais de comercialização só são possíveis graças à sua atuação no mercado interno.

As empresas dos países menos industrializados têm de conviver com as limitações do seu próprio ambiente institucional e dos mercados nacionais, são usualmente reféns dos acordos preferenciais, do protecionismo dos países industrializados e das hierarquias das cadeias produtivas em que atuam. E de um mercado global extremamente competitivo.

Estas empresas tratam de aprender por si mesmas as competências que não são estimuladas na cadeia, indo na direção do full-package, e assim preparar-se para a abertura total dos mercados e para a competição com produtos de classe mundial, tanto com empresas de países emergentes, como a China, quanto dos países desenvolvidos. 
- Qual é a relação entre a participação das empresas dos países em desenvolvimento, Cadeias Produtivas Globais, Progressão Industrial e desenvolvimento social e econômico?

É inegável o aperfeiçoamento, o ganho de competências e de competitividade das empresas dos países asiáticos pela sua participação nas cadeias produtivas globais. É também claro que, atualmente, estes avanços são mais difíceis para as empresas dos países que ingressaram posteriormente no comércio internacional através do sistemas de produção compartilhada - maquila. Apesar do aprendizado e do ganho de participação nas exportações mundiais, as barreiras para os últimos estágios da Progressão Industrial são muito altas, reforçando a governance detida pelas empresas líderes dos países industrializados.

O caso brasileiro mostra que a Progressão Industrial pode ser alcançada através de estratégias de competitividade diferentes das de maquila, que as empresas nacionais podem ser líderes e deter o controle de cadeias produtivas nacionais com atuação no mercado internacional, competindo com as cadeias lideradas por empresas dos países industrializados

Estratégias de competição pela via alta - competição com produtos de maior valor agregado, precisam de maiores investimentos iniciais altos e de coordenação e cooperação entre as empresas, MDO mais qualificada em todos os elos da cadeia, que levam à maior lucratividade, remuneração, condições de trabalho e possibilidades de aprendizado constante.

Paradoxalmente, em ambos os casos estudados, parte da competitividade radica nos custos de MDO da costura, sendo o menos remunerado, beirando à subsistência e com grande informalidade. 
Por outro lado, mesmo no Brasil, onde os elos da cadeia estão completos, o desenvolvimento tecnológico e a inovação mais intensivos em capital ainda dependem das empresas estrangeiras com centros de P\&D nos países de origem.

Frente a estas duas situações, é obrigatório questionar se a Progressão Industrial alcançada pela participação em cadeias produtivas globais é condição suficiente para melhorar as condições de vida da população e impulsionar um verdadeiro progresso industrial nos países em desenvolvimento. As estratégias de desenvolvimento social e econômico devem considerar o marco institucional e a regulamentação dos mercados internacionais. 


\section{CAPÍTULO 6}

\section{CONSIDERAÇÕES FINAIS E CONCLUSÕES}

\subsection{Síntese do trabalho desenvolvido e conclusões}

O estudo focalizou m análise das estruturas das cadeias produtivas e das estratégias e trajetórias próprias das empresas e dos competidores das indústrias têxtil e de vestuário de Honduras e do Brasil.

A pesquisa de campo e a análise comparativa apresentada ao longo dos capítulos anteriores mostraram que as estruturas, relações interempresariais e estratégias de exportação e inserção no comércio internacional de ambos os casos são diferentes; e confirmou a tese de que estas trajetórias levam a resultados diferentes em termos de Progressão Industrial.

O estudo das maquiladoras de roupa hondurenhas, que na última década aumentaram consideravelmente o volume das exportações, confirma que as possibilidades de Progressão Industrial são propiciadas/permitidas pelas empresas líderes, somente até determinados estágios, sendo o mais alto, encontrado na pesquisa, o estágio dos fornecedores de "pacotes completos". 
A pesquisa constatou que a oportunidade de oferecer pacotes completos possibilita o investimento na produção de insumos e na integração vertical das cadeias produtivas, o que inclui investimentos nacional e internacional.

A análise também mostrou que essas exportações são extremamente dependentes do sistema de preferências tarifárias e quotas, implementado pelos Estados Unidos, constituindo seu principal estímulo e limitante.

Há, basicamente, duas tendências a destacar entre as relações das maquilas e as empresas internacionais, e que influenciam o grau de Progressão Industrial para as empresas fornecedoras:

I) As Produtoras com Marcas estadunidenses, que ainda realizam atividades de manufatura nos Estados Unidos ou que têm alianças com fornecedores dos insumos, contratam nas maquiladoras, basicamente as atividades de costura.

II) Os varejistas e comercializadores que não possuem plantas produtoras são mais propensos a contratar a produção de pacotes completos. Aquelas empresas cuja core competence não é o design, poderão contratar, inclusive, pacotes completos das empresas hondurenhas que estão se preparando para oferecer este serviço.

A produção de pacotes completos com design representaria um grande avanço na trajetória de Progressão Industrial das maquiladoras hondurenhas.

A suposta proximidade do fim do Acordo de Têxteis e Confecções - ATC, o ingresso do comércio de têxteis e de vestuário ao sistema da Organização Mundial do Comércio $\mathrm{OMC}^{61}$, assim como o ingresso da China na competição, não parecem desestimular o

\footnotetext{
${ }^{61}$ É preciso lembrar que os Estados Unidos e outros países desenvolvidos realizam enormes esforços para retardar a liberação do comércio de têxteis e vestuário. Na maioria dos acordos bilaterais eles propõem a postergação das quotas e outras barreiras por cinco anos depois do previsto. Um dos acadêmicos
} 
investimento de empresas nacionais e internacionais. É para enfrentar este concorrente que os industriais hondurenhos se preparam, apostando na integração vertical, nas novas competências e habilidades como a resposta rápida para determinados nichos de mercado, a proximidade geográfica e as parcerias consolidadas.

Espera-se que essa competição estimule e reforce a integração com as empresas líderes, possibilitando a Progressão Industrial das empresas hondurenhas em função da competitividade e cooperação nas Cadeias Produtivas Têxtil-Vestuário - CPTV. E que ademais, como algumas empresas já o fazem, procurem desenvolver estratégias que as tornem menos dependentes das preferências, desafiando sua criatividade para vencer as barreiras implícitas nesses acordos comerciais regionais e, portanto, leve as empresas hondurenhas a real e maior Progressão Industrial.

A nossa primeira conclusão é que no caso de Honduras, como exemplo dos países da América Central e do Caribe, os tratados preferenciais para a região e as barreiras a outros fornecedores foram tanto ou mais importantes do que as competências técnicas das empresas líderes quanto das subcontratadas, para desenvolver e consolidar a atual estrutura hierarquizada das cadeias regionais do North American Free Trade Agreement - NAFTA e da Iniciativa para os países da Bacia do Caribe - IBC. Esses acordos constituem a principal causa que permite às empresas estadunidenses preservar a governance perante competidores mais fortes de fora da região, especialmente os asiáticos.

No caso das empresas brasileiras, cujas estratégias têm focado a comercialização de produtos de alta qualidade e a valorização de marcas para nichos de mercado de médio e alto padrão aquisitivo, a inserção no mercado internacional apresenta duas trajetórias:

estadunidenses entrevistados manifestou seu ceticismo a respeito do livre comércio global neste setor, e acreditar mais na factibilidade dos blocos comerciais regionais, como a ALCA. 
A) As primeiras empresas a comercializarem produtos como Marcas originais próprias conquistaram a confiança e aliaram-se a varejistas e distribuidores nos mercados alvo, iniciaram a consolidação da Marca-Brasil com os compradores globais, baseando-se em produtos como jeans e roupas de banho;

B) Empresas mais jovens ou com estratégias de exportação mais recentes utilizam canais próprios de comercialização, através de lojas e showrooms nas principais cidades do mundo e investem alto em lançamentos nos principais desfiles dos centros internacionais da moda, apesar de pouco expressivo em volume e faturamento, estas estratégias possibilitam um maior contato com o consumidor final que associa as marcas originais à marca Brasil.

Ambas estratégias têm a Marca e o Design como ativos mais importantes para conquistar o consumidor final e se apropriar de uma parcela maior do valor agregado ao longo da cadeia.

A concorrência no grande mercado interno entre as marcas nacionais e as estrangeiras contribuiu para a obtenção das competências necessárias às empresas líderes das CPTV. As empresas estrangeiras que atuam no Brasil trouxeram estratégias de gestão da produção e logística que desafiaram os competidores nacionais. A relação com as empresas fornecedoras possibilitou a difusão de novas formas de gestão e outras empresas nacionais realizaram excelente benchmarking.

Tudo isso cria um círculo virtuoso que potencializa a eficiência/competitividade coletiva das empresas brasileiras no mercado internacional. Isto é evidenciado pelo recente sucesso das empresas com marca do Brasil, nos Estados Unidos e na Europa.

Esta análise permite formular a segunda conclusão que confirma a tese apresentada no capítulo 2: 
Há caminhos para a inserção nas cadeias produtivas que suprem os mercados consumidores dos países centrais, diferentes daqueles onde as empresas dos países menos desenvolvidos são simples fornecedores de produtos básicos ou de atividades intensivas em MDO pouco qualificada e com baixa remuneração.

Este tipo de inserção permite o avanço nos estágios de Progressão Industrial e de Modernização Industrial em elos à jusante nas cadeias produtivas: i.e, comercialização, marketing e distribuição mais próximos do consumidor final, em nichos de maior poder aquisitivo, com produtos cujo maior valor agregado se baseia na qualidade, no design, na inovação e no reconhecimento da marca. Uma concorrência no mesmo nível que se dá entre marcas/empresas de países desenvolvidos.

A pesquisa mostra que a maioria das trajetórias empresariais estudadas não é linear, de acordo com a ordem sugerida pela tipologia de Modernização Industrial e de Progressão Industrial. Os modelos apresentados como ponto de partida, não captam a complexidade de todas as cadeias produtivas e das traje tórias de Progressão Industrial, esta questão é de vital importância para as empresas, governos e demais instituições encarregadas das políticas de desenvolvimento industrial e da competitividade das exportações nos países em desenvolvimento. Os estudos da competitividade das empresas e cadeias produtivas dos países em desenvolvimento devem ser mais aprofundados para a sua cabal compreensão, que possibilite sua utilização como ferramentas de planejamento e competitividade. É o que se apresenta a seguir, como modelo generalizável. 
De acordo ao afirmado no item anterior, podemos modelar três tipos de relações entre as empresas líderes das cadeias globais de produção dirigidas pelo mercado, sintetizadas na figura 6.1 apresentada a seguir.

Figura 6.1 Trajetórias de progressão Industrial e Modelos de Relações Interempresariais nas Cadeias Produtivas Globais

Empresas fornecedoras nos países em desenvolvimento
Empresas líderes nos países industrializados / mercados centrais

Modelo Asiático (Coordenadores de fornecimento globais/Global Supliers-GS)

Grandes empresas integradas desde a produção das fibras até a comercialização de marcas (GS: OEM, $\mathrm{ODM}<\mathrm{OBM}$ e GB), regionais-originais ou globaisadquiridas. Coordenam a produção e o fornecimento na forma de redes interempresariais com investimentos no sudeste asiático, Bacia do Caribe e na periferia européia. Grandes escalas de produção, domínio da logística e custos baixos de MDO (OEA e OEM).

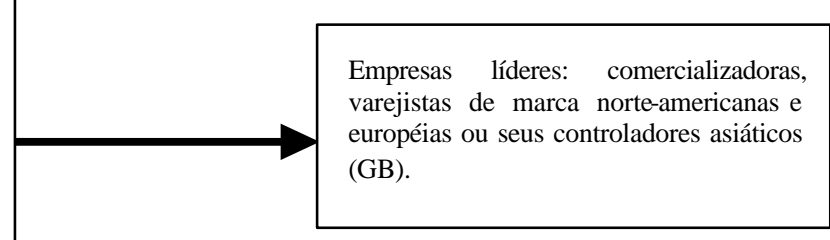

Modelo NAFTA- IBC (Cadeias regionais hierárquicas)

Empresas maquiladoras (OEA ou OEM) nacionais do México, América Central e o Caribe (para NorteAmérica), Joint ventures e investimentos estadunidense e asiático. Pouco valor agregado localmente por atividades intensivas em MDO, insumos provenientes dos EUA. Para as maquilas 807/807A/809 e da Ásia ou localmente para full-package (806) local. Esquemas similares OPT na Europa e sua periferia.

Modelo Brasil (competidores com marcas originais)

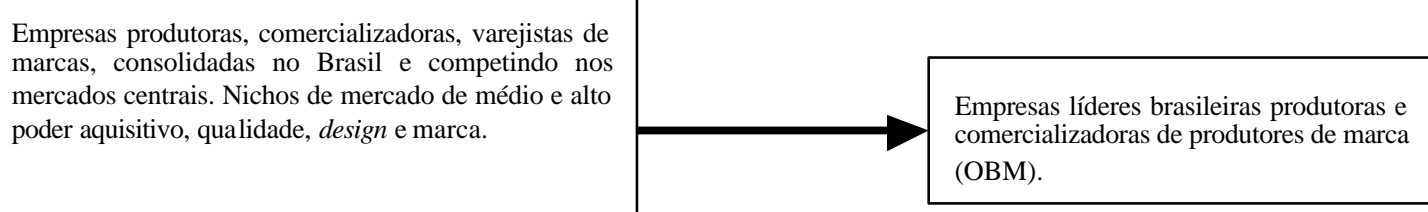

Obs : A predominância de um tipo de cadeias/ empresas/ relação com o mercado internacional, não exclui os outros tipos. No caso do modelo Brasil, por exemplo, este tipo de empresas estratégicas são recentes, porém uma tendência que nos mostra outros tipos de Progressão Industrial que podem ser alcançados por empresas dos países em desenvolvimento.

Nas caixas da direita os tipos de empresas líderes citados representam a predominância respectiva em cada modelo, mas também não são excludentes. 


\subsection{Limitações do estudo}

As CPTV são muito importantes para ambos os países, pelos aspectos antes tratados como: emprego, exportação e processos de industrialização; questões de gênero, organização do trabalho, saúde, ergonomia, segurança; disciplinas como a economia, sociologia, engenharia, design, marketing, comércio internacional, etc., todas importantes, interatuantes e apaixonantes, mas impossíveis de abarcar num estudo só.

Em ambos os casos, os dados secundários não são homogêneos, tanto ao nível das indústrias como ao nível dos dois países. Por exemplo, os volumes e os valores de exportação, têm sua análise complicada pelos diferentes regimes tarifários, muitas vezes, não explícitos.

Quanto aos dados primários, o alto grau de competitividade das indústrias fez os entrevistados responder com extrema cautela e, freqüentemente, guardando sigilo de dados importantes, tendo que utilizar somente dados publicados por instituições ou estudos setoriais.

Devido à dinamicidade das indústrias constituintes e a complexidade das Cadeias Produtivas Têxtil-Vestuário - CPTV, seja em âmbitos globais, regionais ou nacionais, qualquer conclusão, assim como a moda, pode ser efêmera e, portanto, deve ser considerada no seu contexto temporal, considerando-se a evolução do ambiente institucional local ou global em que se modelam as trajetórias.

Essa ressalva é pertinente, pois durante o estagio final de redação da tese, a imprensa veiculou uma notícia importantíssima para o setor: a compra de uma empresa americana por uma empresa têxtil brasileira. Um segundo fato interessante ocorreu ao comprar uma camisa de uma tradicional (produtora com) marca brasileira: na etiqueta de origem do produto - Hong-Kong. Ambos os fatos nos fornecem indícios da Progressão Industriale 
ganho de posições das empresas brasileiras nas CPTV globais. Estas informações precisam ser apuradas, o que não foi possível neste estágio da elaboração da tese e, portanto, não foram incluídas na análise.

\subsection{Possibilidades de generalização para outras cadeias e de estudos complementares no futuro}

A princípio, generalizações do modelo podem se estender para cadeias complementares das CPTV, como calçados e acessórios. As demais indústrias tipificadas como BDC: cerâmica, móveis, brinquedos, eletro-eletrônicos, artesanato, deveriam ser objeto de estudos mais aprofundados e de comparações deste tipo.

A partir do estudo realizado muitas questões apresentam-se pertinentes para estudos futuros, apresentados a seguir:

O caso de Honduras, com o expressado na "maquila" tem, além da sua importância nas CPTV, relevância como motor da industrialização recente e das exportações, é inclui produtos como moveis, frutas secas e camarões. Deveriam ser realizados estudos de competitividade perante concorrentes e em outros mercados onde não existem as preferências para os produtos hondurenhos não existem ou existam outras barreiras à importação.

O caso da indústria brasileira de calçados, por exemplo, é um caso que merece ser revisitado. Apesar de haver estudos realizados com as abordagens de Global Comodity Chains - GCC e de Progressão Industrial, fundamentados nas teorias de clusters e distritos industriais, comparando a indústria de calçados brasileira com as da Itália e da China, seria interessante comparar sua competitividade com outros concorrentes potenciais, como os do MERCOSUL - a Argentina, por exemplo, é famosa pelos seus 
artigos de couro; além dos países da IBC que estão estudam estratégias para implementar maquila de sapatos.

Analisar as potencialidades do design e das estratégias de valorização de marcas ligadas a nomes de designers, na indústria brasileira de calçados deveria ser uma prioridade, dado o sucesso dos estilistas de roupa brasileiros.

Outro tema é o estudo das cadeias em que os varejistas cada vez têm mais governance, como alimentos, frutas frescas e enlatadas, que envolvem elos como o da agricultora, embalagens, transporte, biotecnologia, e que também são objeto de restrições e barreiras comerciais e não comerciais.

Mesmo nas commodities agrícolas há algumas cadeias em que o marketing tem feito um diferencial competitivo, tal é o caso do café colombiano e de outros exóticos aromáticos cafés do mundo em desenvolvimento; recentemente o apelo do mercado justo e dos produtos naturais têm alcançado relevância em produtos como este.

De forma mais ampla, estudar cadeias de valor intersetoriais, que envolvam combinações de indústrias que, a priori são independentes: como a do turismo, que envolve infra-estrutura hoteleira e viária, patrimônio natural, arqueológico e cultural, indústria da aviação, etc...

O papel da Tecnologia da Informação e a governance dos "infomediários" no comércio de produtos e indústrias tradicionais, é um desafio para investimento nos países em desenvolvimento. Em se tratando de tecnologia e conhecimento, a análise da distribuição/relocalização internacional dos centros produtores de conhecimento e da inovação me parecem necessários; por exemplo, países como Japão, no passado, a Turquia e Índia, no presente, estão alcançando grandes desenvolvimentos na engenharia têxtil. 
Jovens destes países formam grande percentual dos alunos de pós-graduação, nas universidades estadunidenses e européias, dos cursos vinculados à gestão e à comercialização da CPTV, enquanto os alunos dos países desenvolvidos são cada vez menos, já que os postos de trabalho foram para o exterior. As universidades nos Estados Unidos e Espanha, por exemplo, estão revendo seus currículos e a viabilidade de alguns cursos superiores e técnicos nessa área.

Não se pode deixar de mencionar que durante a revisão bibliográfica, percebi a carência de estudos comparativos ao nível da América Latina nesta área, seja como competidores, seja para a realização de alianças estratégicas entre as empresas ou entre os países. Para a negociação dos acordos de comércio exterior em bloco, considero que estudos deste tipo deveriam chamar mais a atenção de pesquisadores de todas as áreas de conhecimento.

Por último, em sintonia com as conclusões apresentadas, entende-se que estudos sobre as preferências, restrições e regulamentações comerciais, do comércio internacional devem ser prioridade de equipes multidisciplinares de estudiosos nacionais dos países em desenvolvimento. 


\section{REFERÊNCIAS BIBLIOGRÁFICAS}

ABIT www.abit.org/dados de negócios consultado em -/02/2003.

ABRAVEST. Associação Brasileira da Industria do Vestuário. http://www.abravest.org.br/abravest/projetos.htm, consultado em 05 de setembro de 2000.

ABREU, Alice Rangel de Paiva.: Para além do trabalho: uma agenda de pesquisa para o pólo automotivo do Rio de Janeiro, P. Sessão do Ciclo de Seminários Temáticos Interdisciplinares. "Os Estudos do Trabalho: Novas Problemáticas, Novas Metodologias e Novas Áreas de Pesquisa”, CEBRAP/USP/UNICAMP, São Paulo, 28/05/1999.

AHMA - Honduran Apparel Manufacturers Association. Directory. 2000 - 2001.

AHMA - Honduran Apparel Manufacturers Association. Apparel Industry Statistics. 2001.

AMATO, J. Desintegração vertical/“terceirização" e o novo padrão de relacionamento entre empresas: o caso do complexo automobilístico brasileiro 1993. 236 p. Tese (Doutorado) - Escola Politécnica, Universidade de São Paulo. São Paulo, 1993.

AMSDEM, A. Asia's next giant: South Korea and late industrialization. Oxford University Press. 1989.

APPELBAUM, R.; GEREFFI, G. Power and Profits in the Apparel Commodity Chain. In BONACICH, E. et al. Global Production: the Apparel Industry in Pacific Rim. Philadelphia, PA: Temple University Press, 1994. 
APPELBAUM, R.; SMITH, D.; CHRISTERSON, B. Commodity Chains and Industrial Restructuring in the Pacific Rim: Garment Trade and Manufacturing. In GEREFFI, G. et KORNZENIEWICZ, M. Commodity Chains and Global Capitalism(Eds.), Praeger. Wesport. 1994.

BAIR, J.; Sewing up development? NAFTA and the Mexican Apparel Industry. 2002. 422 p. Tese (Doutorado) - Department of Sociology, Duke University. Durham, NC. 2002.

BAIR, J; GEREFFI. G. NAFTA and the Apparel Commodity Chain: Corporate Strategies, Interfiim Networks, and Industrial Upgrading. In GEREFFI, G.; SPENER, D.; BAIR, J. (Eds.) Free trade and uneven development; the North American Apparel Industry after NAFTA. Temple University Press. Philadelphia. 2002.

BANCO CENTRAL DE HONDURAS. Honduras em cifras 1999-2001. Subgerencia de Estúdios Econômicos. Tegucigalpa, M.D. C., Honduras C. A. www.bch.hn consultado em setembro de 2002.

BANCO CENTRAL DE HONDURAS. La Actividad maquiladora en Honduras 1998-2001. Subgerencia de Estúdios Econômicos. Tegucigalpa, M.D.C., Honduras C. A. Agosto de 2001.

BAUMANN, R. O Brasil e a economia global Rio de Janeiro. Campus, 1996.

BASTOS, C. Estudo da competitividade da indústria brasileira: Competitividade da indústria do vestuário. Nota técnica setorial do complexo têxtil. IE/UNICAMP IEI/UFRJ - FDC - FUNCEX. Campinas, SP. 1993.

BENTO, Liliana. Renner planeja faturar $65 \%$ mais . Exame News, No. 61. 22/09/2000.

BOVET, D.; MARTHA, J. Redes de Valor; Aumente seus Lucros pelo uso da Tecnologia de Informação na Cadeia de Valor. São Paulo: Negocio Editora. 2001.

BONACICH, E. et al. Global Production: the Apparel Industry in Pacific Rim. Philadelphia, PA: Temple University Press, 1994. 
BUITELAAR, R. América Central y República Dominicana: Modernización y ajuste en la maquila de confección. In BUITELAAR, R.; RODRIGUEZ, E. (Eds.) Impacto del TLCAN en las exportaciones de prendas de vestir de los países de América Central y República Dominicana. Naciones Unidas, CEPAL, Sede Subregional em México. México D.F. - Banco Interamericano de Desarrollo (BID), Instituto para la Integración de América latina y el Caribe INTAL, Buenos Aires. 2000.

CAIXETA, Nely. "O brilho da moda" Reportagem da capa; Revista Exame Edic. 777, ano 36, no. 21, 16 de Outubro, Editora Abril, São Paulo, 2002.

CARRILlO, J.; HUALDE. A. Maquiladoras de Tercera Generación: El caso de Delphi - General Motors. El Colegio de la Frontera Norte. Mimeo. 1997.

CARVALHO, M.; SERRA, N. Design e Competitividade: O caso da cadeia têxtil e vestuário paulista. In XX Simpósio de Gestão da Inovação Tecnológica. 17 a 20 de novembro. São Paulo. 1998.

CEPAL. Centroamérica, México y República Dominicana: maquila y trnasformación productiva. Serie Estudios y perspectivas - Sede Subregional de la CEPAL en México, Unidad de Desarrollo Industrial. - Naciones Unidas. México, D.F., LC/MEX/L.359. 28 de julho de 1998.

CHACÓN. F. Comercio internacional de los textiles y el vestido: Reestructuración global de las fuentes de oferta en EE.UU. durante la década de los años noventa. In BUITELAAR, R.; RODRIGUEZ, E. (Eds.) Impacto del TLCAN en las exportaciones de prendas de vestir de los países de América Central y República Dominicana. Naciones Unidas, CEPAL, Sede Subregional em México. México D.F. - Banco Interamericano de Desarrollo (BID), Instituto para la Integración de América latina y el Caribe INTAL, Buenos Aires. 2000.

CRUZ-MOREIRA, J.R. Perspectivas para las cooperativas de Confección de Vestuário en el estado de São Paulo, Brasil. In CONGRESSO DA ASOCIACION LATINOAMERICANA DE SOCIOLOGIA, Antigua Guatemala. XXIII ALAS. Anais - CD-ROM e Livro de Resumos, 2001.

COTIAS, A. Cartões de credito têm origem no velho carnê. Finanças \& Mercados. P. B-1. Gazeta Mercantil. 24 de março de 2003 a.

COTIAS, A. Credito banca rentabilidade do varejo. Finanças \& Mercados. P. B-1. Gazeta Mercantil. 24 de março de 2003 b. 
DICKEN, P. Global shift: transforming the world economy. $3^{\mathrm{a}}$. ed. New York, London, The Guilford Press, 1998

DICKERSON, K. Textiles and Apparel in the Global Economy, $3^{\mathrm{a}}$.ed. Englewood Cliffs, NJ: Merrill, 1999.

DUSSEL, E. Un análisis de la competitividad de las exportaciones de prendas de vestir de Centroamérica utilizando los programas y la metodología CAN y MAGIC. CEPAL. Serie Estudios y perspectivas - Sede Subregional de la CEPAL en México, Unidad de Desarrollo Industrial. - Naciones Unidas. México, D.F., julho de 2001

FAJNZYLBER, F. Inserción internacional e innovación institucional. Revista de la CEPAL. No. 49. 1991. Apud CEPAL. Centroamérica, México y República Dominicana: maquila y trnasformación productiva. Serie Estudios y perspectivas - Sede Subregional de la CEPAL en México, Unidad de Desarrollo Industrial. Naciones Unidas. México, D.F., LC/MEX/L.359. 28 de julho de 1998.

FERNÁNDEZ, J. Las Mujeres trabajadoras de la Maquila en Centroamérica. OIT. 2000. Resumo In MAZIER, A.; CASTILLO, N. El empleo en la maquila: mitos e realidades. Investigación realizada en la zona central del país. Instituto de Investigaciones Económicas y Sociales, Facultad de Ciencias Económicas, Universidad Nacional Autónoma de Honduras, Ciudad Universitaria, Tegucigalpa. Mayo de 2002.

FERRAZ, J. et al. Made in Brazil: desafios competitivos para a indústria. Rio de Janeiro: Campus. 1996.

FIDE - Fundación para la Inversión y el Desarrollo de las Exportaciones. Directório de Exportadores: HONDURAS 2002. FIDE. Tegucigalpa: Febrero de 2002.

FIORA, L. A Benetton quer achar o fio da meada. Revista Exame . Edição 645, Ano 30, No. 20. 24 de setembro de 1997.

FLEURY, A. C. C. The new pattern of operations management in developing countries: the case of Brazil. International Journal of Operations and Production Management, v. 5/6, julho de 1999. 
FLEURY, A.C.C.; FLEURY, M. T. Developing competencies in different organizational arrangements. Latin American Business Review. Vol. 3. No. 3. pp. 75-91. Binghamton, NY. 2002.

FLEURY, A.C.C.; FLEURY, M. T. Estratégias empresariais e formação de competências: um quebra-cabeça caleidoscópico da indústria brasileira. São Paulo: Atlas, 2000.

FLEURY, A.C.C.; FLEURY, M. T. Assessing Development Strategies; employment creation versus competence gene ration: a comparation between the Mexican and Brazilian industries poles. Working Paper. São Paulo, Universidade de São Paulo. 1998.

FLEURY, A.C.C.; FLEURY, M. T. Aprendizagem e inovação organizacional: as experiências de Japão, Coréia e Brasil, São Paulo: Atlas. 1995.

FLEURY, A.C.C.: FLEURY, M.T.: CRUZ-MOREIRA, J. R., et al: A competitividade das cadeias produtivas da Industria têxtil baseadas em fibras químicas. Relatório de pesquisa contratada pelo BNDES. Fundação Carlos Alberto Vanzolini. 2001. Disponível em:

http://www.vanzolini.org.br/areas/desenvolvimento/cadeias-texteis/.

FORTES, A. Nós do Quarto Distrito... A classe trabalhadora porto-alegrense e a era Vargas. Tese (Doutorado) IFCH-UNICAMP. Campinas, SP. 2001.

FRUIN, W. The Japanese enterprise system: competitive strategies and cooperative structures. Oxford University Press. New York. 1992.

FUNDACIÓN FRIEDRICH EBERT STIFUNG. Las maquilas en Honduras y el Monitoreo Independiente en centro América, Tegucigalpa. 1998.

GARCÍA, R.; CRUZ-MOREIRA, J.R. Complexo Têxtil, Vestuário e Calçados: um cluster de atividades resistente. Projeto EMURB/CEBRAP: Estratégias de reestruturação da Região Central da cidade de São Paulo. São Paulo. 2003.

GEREFFI, G. Beyond the Producer-driven/Buyer-driven Dichotomy: The Evolution of Global Commodity Chains in the Internet era. IDS-Bulletin. Vol. 32, No. 3. julho de 2001 . 
GEREFFI, G. El tratado de libre comercio de América del Norte en la transformación de la industria del vestido: bendición o castigo? Red de Inversiones y Estrategias Empresariales. CEPAL- ECLAC. Santiago, Octubre de 2000 .

GEREFFI, G. International trade and industrial upgrading in the apparel commodity chain. Journal of International Economics. Vol 48, No.1, pp.37-70. Junho de 1999.

GEREFFI, G. The organization of buyer-driven global commodity chains: how U.S. retailers shape the overseas production networks. In GEREFFI, G.; KORNZENIEWICZ, M. Commodity Chains nad Global Capitalism (Eds.), Praeger. Wesport. 1994.

GEREFFI, G.; HUMPHREY, J; STURGEON,T. Developing a Theory for Global Value Chains: a Framework Document. Global Value Chains Conference. Rockport. 2002 .

GEREFFI, G.; KORNZENIEWICZ, M. Commodity Chains and Global Capitalism (Eds.), Praeger. Wesport. 1994.

GIBBON, P. Global Commodity Chains and Economic Upgrading Less Developed Countries. Centre for development Research. Working paper. Copenhagen: 2000

GITLI, E. La Industria maquiladora en Centroamérica; Informe para el Seminario Subregional de Empleadores de Cetroamérica y Republica Dominicana. Guatemala. Oficina de la OIT para América Central y Panamá. 1997.

GIRVAN, D. Transnational Corporations and Non-fuel Primary Commodities in Developing Countries, World Development, 15, 5 May 1987.

GOLFRANK, W. Fresh Demand: The Consumption of Chilean Produce in the United States. In GEREFFI, G. et KORNZENIEWICZ, M. Commodity Chains and Global Capitalism(Eds.), Praeger. Wesport. 1994.

GORINI, A.; Panorama do setor têxtil no Brasil e no Mundo: reestruturação produtiva e perspectivas. BNDES Setorial. N.12, p. 17-50. Rio de Janeiro: setembro de 2000. 
GORINI, A. O segmento índigo. BNDES 2, SET-1009, Rio de Janeiro:1999

GOULARTI $\mathrm{F}^{\mathrm{o}}$. A.; NETO, R. A indústria do vestuário; economia, estética e tecnologia. Florianópolis. Livraria Editora Obra Jurídica. 1997

HAGUENAUER, L.; BAHIA, L.; CASTRO, P.; RIBEIRO, M.; Evolução das Cadeias Produtivas Brasileiras na Década de 90. IPEA/INPES. Texto p/discussão No. 786. Brasília: 2001.

HARLAND, C. Supply network strategies: the case of health supply. International Journal of Operation \& Production Management. v. 19, n 2, pp,125-131. 1996.

HARLAND. M.; MORÃES.. E. (Eds). Collins Gem Dictionary InglêsPortuguês/Português-Inglês. DISAL, 1986

HOFFMAN, K. Clothing, Chips and Competitive Advantage: The Impact the Microelectronic on Trade and Production in the Garment Industry. World Development 13, No. 3. pp. 371-392. 1985.

HOPKINS, T.; WALLERSTEIN, I. Commodity Chains: Construct and Research. 1994. In GEREFFI, G. et KORNZENIEWICZ, M. Commodity Chains and Global Capitalism(Eds.), Praeger. Wesport. 1994.

HOUAISS, A.; VILlaR, M. Dicionário Houaiss da Língua Portuguesa. Instituto Antônio Houaiss de Lexicografia e banco de Dados da Língua Portuguesa S/C Ltda. Rio de janeiro. Objetiva. 2001.

HUMPHREY, J.; SCHMITZ, H. Governance and Upgrading in Global Value Chains, a background paper for the Bellagio Value Chain Workshop. IDS - University of Sussex. UK. Agosto de 2000.

HUMPHREY, J.; SCHMITZ, H. “Upgrading”. Working paper. 31 de janeiro de 2000.

IBGE. Brasil uma visão geográfica nos anos 80. Rio de Janeiro. 1995. apud KONTIC, B. Redes produtivas e aprendizado a indústria do vestuário da RMSP: espaço regional para políticas industriais. In II Encontro da Associação Brasileira de Economia Regional. FEA/USP. São Paulo. Anais. 2002. 
IEMI - Instituto de Estudos e Marketing Industrial S/C Ltda. Primeiro Relatório do setor Têxtil Brasileiro. São Paulo: junho de 2001. In PROCHNIK. V. Estudo da Competitividade de Cadeias Integradas no Brasil: impactos das Zonas de Livre Comercio. Relatório de Pesquisa. Cadeia Têxtil e Confecções. Nota Técnica Final. Campinas: UNICAMP-IE. Campinas, SP. 2002.

International Parks Inc.. A private sector export processing zone system for Honduras: Report for FIDE Tegucigalpa, Honduras. Flagstaff: 12 de agosto de 1986.

JENKINS. M.; ESQUIVEL, G.; LARRAIN, F. Export Processing Zones in Central America. Development Discussion Paper: Central America Project Series. DP no. 4. Harvard Institute for International Development, Harvard University. Julho. 1998.

KAPLINSKY, R.; MORRIS, M. A handbook for value Chain Analysis. IDRC. 16 de novembro de 2001.

KAPLINSKY, R. Globalization, industrialization and sustainable growth : the pursuit of the nth rent. IDS - Discussion Paper 365. Brighton: Institute Of Development Studies. University of Sussex. 1998.

KENNEDY, M.; CARDONA, M. Mujeres en la Maquila; el caso de la ZIP Choloma. CEM-H. 1995. In MAZIER, A.; CASTILLO, N. El empleo en la maquila: mitos e realidades. Investigación realizada en la zona central del país. Instituto de Investigaciones Económicas y Sociales, Facultad de Ciencias Económicas, Universidad Nacional Autónoma de Honduras, Ciudad Universitaria, Tegucigalpa: Mayo de 2002.

KILDUFF, P.; PRIESTLAND, C. Strategic Transformation in the US Textile \& Apparel Industries; A Study of Business Dynamics with Forecasts up to 2010. North Carolina State University. Raleigh, NC. Maio de 2001.

KONTIC, B. Redes produtivas e aprendizado a indústria do vestuário da RMSP: espaço regional para políticas industriais. In II Encontro da Associação Brasileira de Economia Regional. Anais FEA/USP. São Paulo. 2002.

KONTIC, B. Aprendizado e metrópole: a reestruturação produtiva indústria do vestuário em São Paulo. 2001. 168p. Dissertação (Mestrado). - FFLCH, Universidade de São Paulo. São Paulo. 2001. 
KORZENIEWICZ, M. Commodity Chains and Marketing Strategies: Nike and the Global Atlhetic Footwear Industry. In GEREFFI, G. et KORNZENIEWICZ, M. Commodity Chains nad Global Capitalism(Eds.), Praeger. Wesport. 1994.

Lafis - Brasil - Têxtil e Vestuário : Confecções, relatório setorial. www.lafis.com.br 2001. Apud PROCHNIK. V. Estudo da Competitividade de Cadeias Integradas no Brasil: impactos das Zonas de Livre Comercio. Relatório de Pesquisa. Cadeia Têxtil e Confecções. Nota Técnica Final. Campinas: UNICAMP-IE. Campinas, SP. 2002.

LAZZARINI, S. Estudos de caso: aplicabilidade e limitações do método para fins de pesquisa. Economia \& Empresas. São Paulo. Vol. 2. No. 4 pp.17-26. Out- Dez. 1995.

LEE, N.; CASON, J. Automobile Commodity Chains in the NCs:A Comparison Of South Korea, Mexico, and Brasil. In GEREFFI, G. et KORNZENIEWICZ, M. Commodity Chains nad Global Capitalism(Eds.), Praeger. Wesport. 1994.

LIMA, J.C. As artimanhas da flexibilização: o trabalho terceirizado em cooperativas de produção. São Paulo: Terceira Margem. 2002.

LIMA, J. Cooperativas de produção industrial: autonomia e subordinação do trabalho. Departamento de Ciências Sociais, Universidade Federal da Paraíba, 1998.

McCORMICK, D.; SCHMITZ, H. Manual for Value Chain Research on Homeworkers in the Garment Industry WIEGO/IDS- Institute for Development Studies, Sussex. 2002.

MANO, Cristiane. "A ditadura da moda" Revista Exame Edic. 777, ano 36, no. 21, 16 de Outubro, Editora Abril, São Paulo, 2002.

MATEWS, D, Can the Dominican Republic's Export-Processing Zones survive NAFTA? In GEREFFI, G.; SPENER, D.; BAIR, J. (Eds.) Free trade and uneven development; the North American Apparel Industry after NAFTA. Temple University Press. Philadelphia. 2002.

MAZIER, A.; CASTILlO, N. El empleo en la maquila: mitos e realidades. Investigación realizada en la zona central del país. Instituto de Investigaciones Económicas y Sociales, Facultad de Ciencias Económicas, Universidad Nacional Autónoma de Honduras, Ciudad Universitaria, Tegucigalpa. Mayo de 2002. 
MONCADA, E. Las dos caras de la maquila em Honduras. OIT/POSCAE-UNAH. Documento de Trabajo No. 10. Julho de 1995.

MORTIMORE, M. When does apparel become a peril? On the nature of industrialization in the Caribbean Basin. In GEREFFI, G.; SPENER, D.; BAIR, J. (Eds.) Free trade and uneven development; the North American Apparel Industry after NAFTA. Temple University Press. Philadelphia. 2002.

MORTIMORE, M.; ZAMORA, R. La competitividad de internacional de la industria del vestir en Costa Rica . CEPAL.. Santiago. 1998.

NEWMAN, K. Tejedores de Sueños. National Geographic en Español. Vol. 12 . No.1. Janeiro de 2003.

OIT. La situación sociolaboral en las zonas francas y empresas maquiladoras del Istmo Centroamericano y la República Dominicana. Organización Interncaioal del Trabajo, Oficina para América Central y Panamá. 1996.

ÖZVEREN, E. The Shipbuilding Commodity Chain; 1590-1790. In GEREFFI, G. et KORNZENIEWICZ, M. Commodity Chains and Global Capitalism (Eds.), Praeger. Wesport. 1994.

PELLIZON, S. The Grain Flour Commodity Chain, 1590-1790. In GEREFFI, G. et KORNZENIEWICZ, M. Commodity Chains and Global Capitalism (Eds.), Praeger. Wesport. 1994.

PIORE, M.; SABEL, C. The second industrial divide : possibilities for prosperity. New York: Basic Book. 1984.

PORTER, M. A Vantagem Competitiva das Nações. 1990. Tradução de DUTRA,W. Editora Campos. 1993.

PORTER, M. Competitive Advantage: Creating and Sustaining Superior Performance. The Free Press. New York. 1985.

PROCHNIK. V. Estudo da Competitividade de Cadeias Integradas no Brasil: impactos das Zonas de Livre Comercio. Relatório de Pesquisa. Cadeia Têxtil e Confecções. Nota Técnica Final. Campinas: UNICAMP-IE. Campinas, SP. 2002. 
RABELOTTI, R.; The eroding effect of globalization on an Italian industrial district: the case of Brenta. Department of Economics and Quantitative Methods. Università del Piemeonte orièntale. 2001.

RAIKES, P.; JENSEN, M.; PONTE, S. Global Commodity chain Analysis and the French filière approach Comparison and Critique. Economy and Society. Vol. 29. pp. 390-417. 2000.

SERRENTINO, A. apud COTIAS, A. Cartões de credito têm origem no velho carnê. Finanças \& Mercados. P. B-1. Gazeta Mercantil. 24 de março de 2003 a.

SALOMÃO, C. Crescem as exportações para a América do Norte. Gazeta Mercantil; Indústria \& Serviços: C-1. Têxteis e Confecções. 18 de fevereiro de 2003.

SCHERER, A. A estratégia empresarial e os determinantes da difusão de tecnologia: um estudo sobre a indústria de vestuário do Rio Grande do Sul. Dissertação (Mestrado). Curso de Pós-graduação em Economia, Universidade Federal do Rio Grande do Sul. 1994.

SILVESTRINI, G. Pequeno varejo ajuda Marisol a reforçar lucros. Empresa \& Carreiras, Gazeta Mercantil, 28 de fevereiro de 2000.

SMITH, E. The Crown Prince of Seventh Avenue. The Industry Standard. p.56. 12 de fevereiro de 2001.

TESSARI, C. A indústria da moda: Analise Setorial. Panorama Setorial. Gazeta Mercantil. Janeiro de 2001.

TESSARI, C. Fiação, Tecelagem e Malharia: Analise Setorial. Panorama Setorial. Gazeta Mercantil. Novembro de 1999.

The Services Group. Honduras Free Zone Development: a Strategy for FIDE. Draft Final Report to the Fundación para la Investigación y el Desarrollo Empresarial. Arlington, Virginia: January, 1988.

TORRES, O. Honduras: La industria maquiladora. CEPAL. LC/MEX/L.325, 21 de abril de 1997. 
USITC - Production Sharing: US Imports Under Harmonized Tariff Schedule subheadings 9802.00.60 and 9802.00.80, 1989-1992. United States International Trade Commission. Publication 2729. Washington: February, 1996:1-1 apud, GITLI, E. La Industria maquiladora en Centroamérica; Informe para el Seminario Subregional de Empleadores de Cetroamérica y Republica Dominicana. -p.8. Guatemala. Oficina de la OIT para América Central y Panamá. 1997.

VANGSTRUP, U. Knitting the networks between Mexican producers and the U.S. market. In GEREFFI, G.; SPENER, D.; BAIR, J. (Eds.) Free trade and uneven development; the North American Apparel Industry after NAFTA. Temple University Press. pp. 246-265. Philadelphia. 2002.

VERISSIMO, S. Made in Piauí. Revista Exame, Edição 777, ano 36, no. 21, 16 de Outubro, Editora Abril, São Paulo, 2002.

WALKER, I. Mercados regionales de trabajo y localizaci' pn de las Zonas Industriales de Procesamiento en Honduras. In ALTENBURG, T.; NUHN, H. Apertura comercial en Centroamérica: nuevos retos para la industria. Editorial DEI. San José. 1995.

WATANABE. S., Technological linkages between formal and informal sectors of manufacturing industry. Working Paper 34, Technology and Employment Program, WEP 2-22, ILO: Geneva. 1978

WATANABE, S., Subcontracting, industrialization and employment creation. International Labor Review, Vol. 104 No. 1 e 2. 1971.

YIN, R. Case study research: design and methods. Newbury Park. R. Sage. Thousand Oaks. California. 1984.

ZELAYA, R. et al. Zonas industriales de procesamiento en Honduras. UNITEC. Tegucigalpa: 16 de março de 1998. 


\section{APÊNDICES}




\section{A COMPETITIVIDADE DAS CADEIAS PRODUTIVAS DA INDÚSTRIA TÊXTIL BASEADA EM FIBRAS QUÍMICAS}

Empresa:

Entrevistado:

Cargo:

Tempo de empresa: (anos)

\section{Caracterização da empresa}

1.1 Tipo de transformação - posição na cadeia - nível de integração. (Marcar com X)

\begin{tabular}{|l|l|l|l|l|l|l|l|l|}
\hline Insumos & Fibras & Fiação & Tecelagem & Malharia & Acabamento & Confecção & Distribuição & Comercialização \\
\hline & & & & & & & & \\
\hline
\end{tabular}

1.2 Tipo de Nicho de Mercado final à que se destina seu produto/serviço. (Marcar com X)

\begin{tabular}{|c|c|c|c|c|c|c|c|c|}
\hline $\begin{array}{c}\text { Vestuário } \\
\text { feminino }\end{array}$ & $\begin{array}{c}\text { Vestuário } \\
\text { masculino }\end{array}$ & $\begin{array}{c}\text { Vestuário } \\
\text { Infantil }\end{array}$ & $\begin{array}{c}\text { Jeans } \\
\text { wear }\end{array}$ & $\begin{array}{c}\text { Moda } \\
\text { praia }\end{array}$ & $\begin{array}{c}\text { Esporte } \\
\text { / lazer }\end{array}$ & $\begin{array}{c}\text { R. intimas } \\
\text { masculinas }\end{array}$ & Lingerie & $\begin{array}{c}\text { Meia } \\
\text { feminina }\end{array}$ Masculina \\
\hline & & & & & & & & \\
\hline
\end{tabular}

\begin{tabular}{|c|c|c|c|c|c|c|c|c|}
\hline $\begin{array}{c}\text { Cama e } \\
\text { mesa }\end{array}$ & Atoalhados & Tapeçaria & Cortinas & Carpetes & $\begin{array}{c}\text { Tecidos } \\
\text { técnicos }\end{array}$ & Automobilística & $\begin{array}{c}\text { Roupas } \\
\text { Profissionais }\end{array}$ & $\begin{array}{c}\text { Outros } \\
\text { /Qual? }\end{array}$ \\
\hline & & & & & & & & \\
\hline
\end{tabular}

1.3 Padrão do consumidor final

Popular [vestuário padrão] ( ) Diferenciado [vestuário de moda]( )

1.4 Estrutura de capital. (Marcar com X)

\begin{tabular}{|c|c|c|c|}
\hline $100 \%$ nacional & $<50 \%$ estrangeira & $>50 \%$ estrangeira & Joint venture \\
\hline & & & \\
\hline
\end{tabular}

1.5 Vinculação da empresa a grupos industriais/financeiros ? S ( ) N ( ) Quais? 
1.6 A gestão da empresa é feita por:

Administradores profissionais contratados Pessoas da família

1.7 Evolução da capacidade instalada e destino da produção (últimos 5 anos)

\begin{tabular}{|c|c|c|c|c|c|c|}
\hline \multirow[b]{2}{*}{ Ano } & \multirow{2}{*}{$\begin{array}{l}\text { Capacidade } \\
\text { instalada } \\
\text { (ton./ano) ou } \\
\text { (m./ano) }\end{array}$} & \multirow{2}{*}{$\begin{array}{l}\text { No. de } \\
\text { plantas }\end{array}$} & \multirow[t]{2}{*}{ Produção } & \multirow[t]{2}{*}{ Localização } & \multicolumn{2}{|c|}{ Destino da produção (\%) } \\
\hline & & & & & \begin{tabular}{|l} 
Nacional \\
\end{tabular} & Exportação \\
\hline 1996 & & & & & & \\
\hline 1997 & & & & & & \\
\hline 1998 & & & & & & \\
\hline 1999 & & & & & & \\
\hline 2000 & & & & & & \\
\hline
\end{tabular}

Eventuais observações sobre evolução

\section{Mercados e relações na Cadeia Produtiva}

2.1 Principais mercados / exportação nos dois últimos anos

\begin{tabular}{|c|c|c|c|c|c|c|c|}
\hline \multirow{3}{*}{ Ano } & \multicolumn{5}{|c|}{ Mercado de destino da produção } & \multirow{3}{*}{$\begin{array}{c}\% \text { da } \\
\text { Produçãa } \\
0\end{array}$} & \multirow{3}{*}{$\begin{array}{c}\text { Canais de } \\
\text { comercialização * }\end{array}$} \\
\hline & \multirow{2}{*}{$\underset{I}{\text { Regiona }}$} & \multirow{2}{*}{ Nacional } & \multicolumn{3}{|c|}{ Exportação } & & \\
\hline & & & Mercosul & USA & Outros & & \\
\hline \multicolumn{8}{|l|}{2000} \\
\hline & & & & & & & \\
\hline \multirow{2}{*}{1999} & & & & & & & \\
\hline & & & & & & & \\
\hline
\end{tabular}

* Canais de comercialização - Indique segundo a relação abaixo

1 - Consumidor final- loja( )/redes próprias ( ) 5 - Redes de Varejo

2 - Lojas independentes

6 - Brokers / Trading Companies

3 - Atacadistas

7 - Consórcios de Exportação

4 - Representantes comerciais

8 - Outros - explique: 
2.2 Principais Clientes

\begin{tabular}{|c|c|c|c|c|c|c|c|}
\hline \multicolumn{3}{|c|}{ Nacionais } & \multicolumn{5}{c|}{ Exportação } \\
\hline No & Cliente & $\begin{array}{c}\text { \% da } \\
\text { Produção }\end{array}$ & $\begin{array}{c}\text { Tipo de } \\
\text { Transação * }\end{array}$ & No. & Cliente & $\begin{array}{c}\text { Tipo de } \\
\text { Produção }\end{array}$ & \begin{tabular}{c} 
Transação * \\
\hline 1
\end{tabular} \\
\hline 2 & & & & 1 & & & \\
\hline 3 & & & & 2 & & & \\
\hline 4 & & & & 3 & & & \\
\hline 5 & & & & 4 & & & \\
\hline
\end{tabular}

* Tipos de Transação:

1 - Mercado spot ( Cada vez é uma vez, transações sem reciprocidade e repetitividade )

2 - Alianças de curto prazo ( Empresas se compõem para um projeto ou venda únicos )

3 - Parcerias de longo prazo ( As empresas tendem a cooperar entre si repetidamente )

4 - Relações hierárquicas ( As transações ocorrem dentro de firmas verticalmente integradas)

5 - Relações baseadas na família

6 - Relações baseadas em etnia

2.3 Principais fornecedores

\begin{tabular}{|c|c|c|c|c|c|c|c|}
\hline \multicolumn{4}{|c|}{ Nacionais } & \multicolumn{4}{|c|}{ Importação } \\
\hline No & Fornecedor & $\%$ & $\begin{array}{c}\text { Tipo de } \\
\text { Transação * }\end{array}$ & No. & Fornecedor & $\%$ & $\begin{array}{c}\text { Tipo de } \\
\text { Transação * }\end{array}$ \\
\hline \multicolumn{8}{|c|}{ De matérias primas } \\
\hline 1 & & & & 1 & & & \\
\hline 2 & & & & 2 & & & \\
\hline 3 & & & & 3 & & & \\
\hline \multicolumn{8}{|c|}{ De equipamentos } \\
\hline 1 & & & & 1 & & & \\
\hline 2 & & & & 2 & & & \\
\hline 3 & & & & 3 & & & \\
\hline \multicolumn{8}{|c|}{ De Tecnologia/ conhecimento } \\
\hline 1 & & & & 1 & & & \\
\hline 2 & & & & 2 & & & \\
\hline 3 & & & & 3 & & & \\
\hline
\end{tabular}

* Tipos de Transação: Utilize a mesma tipologia do item VIII.1

2.4 Principais Concorrentes

\begin{tabular}{|c|c|c|c|c|c|c|l|}
\hline \multicolumn{3}{|c|}{ Mercado Nacional } & \multicolumn{4}{c|}{ Mercado Exterior } \\
\hline No & Concorrente & $\begin{array}{l}\text { Nicho de } \\
\text { mercado }\end{array}$ & $\begin{array}{l}\text { Fatia de } \\
\text { mercado }\end{array}$ & No. & Cliente & $\begin{array}{l}\text { Nicho de } \\
\text { mercado }\end{array}$ & $\begin{array}{l}\text { Fatia de } \\
\text { mercado }\end{array}$ \\
\hline 1 & & & & 1 & & & \\
\hline 2 & & & & 2 & & & \\
\hline 3 & & & & 3 & & & \\
\hline
\end{tabular}


A empresa realiza Benchmarking sistematicamente?

Como?

\section{Estratégia competitiva}

3.1 Qual é a principal estratégia competitiva da empresa (assinale uma - marque $\mathrm{x}$ )

Excelência operacional : Produtos padronizados - Otimização da relação qualidade / preço Inovações constantes em produtos

Orientação para o cliente: Conhecimento profundo das necessidades de alguns clientes específicos

\subsection{Presença de Vantagens Competitivas}

Preencha o quadro abaixo utilizando a seguinte tabela:

1 - $\quad$ A empresa TEM ALTA Vantagem Competitiva neste aspecto

2 - $\quad$ A empresa TEM BAIXA Vantagem Competitiva neste aspecto

3 - $\quad$ A empresa NÃO TEM Vantagem Com petitiva neste aspecto

Conhecimento dos mercados

Escala de produção / modernidade equipamentos

Capacidade de gestão interna

Capacidade de design

Marca forte

Capacidade de fornecer "full package" (desenvolvimento e gestão de produtos e processos, fabricação embalagem)

Forma de comercialização

Articulação na cadeia produtiva (fornecimento e comercialização)

Capacidade de criar parcerias

Qualidade da matéria prima

Diversidade da matéria prima

Custo da mão de obra

Qualidade dos equipamentos

Inovação em produtos

Localização de plantas para reduzir custos e obter subsídios

Localização de plantas para otimizar os custos de logística

Outras

$\begin{array}{cc}\text { locais } & \text { globais } \\ (\quad) & (5) \\ () & (1) \\ () & (1) \\ () & (1) \\ () & (1)\end{array}$

:

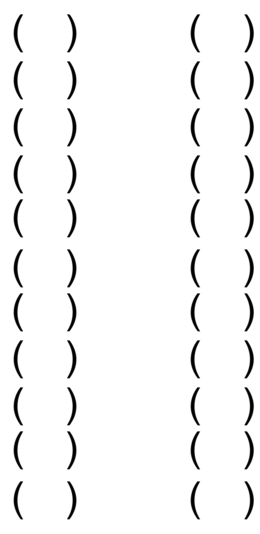

\subsection{Desvantagens competitivas}


Preencha o quadro abaixo utilizando a seguinte tabela:

1 - $\quad$ A empresa TEM ALTA Desvantagem Competitiva neste aspecto

2 - $\quad$ A empresa TEM BAIXA Desvantagem Competitiva neste aspecto

3 - $\quad$ A empresa NÃO TEM Desvantagem Competitiva neste aspecto

Desvantagens Competitivas (Relacionadas ao ambiente onde a empresa

Em relação a opera)

Preço dos insumos

Mecanismos de crédito e financiamento

Custo de capital para investimento

Localização (custos de mão de obra e logística)

Tributação

Qualificação de recursos humanos existentes

Outros

concorrentes...

Como os acordos internacionais influenciam a estratégia competitiva da empresa?

\section{Estrutura e organização}

4.1 Qual é a função crítica de sucesso no negócio da empresa ? (Colocar em ordem de importância)

\section{Função}

Marketing e Vendas

Produção

Desenvolvimento de produtos

Finanças

Recursos Humanos

Outra
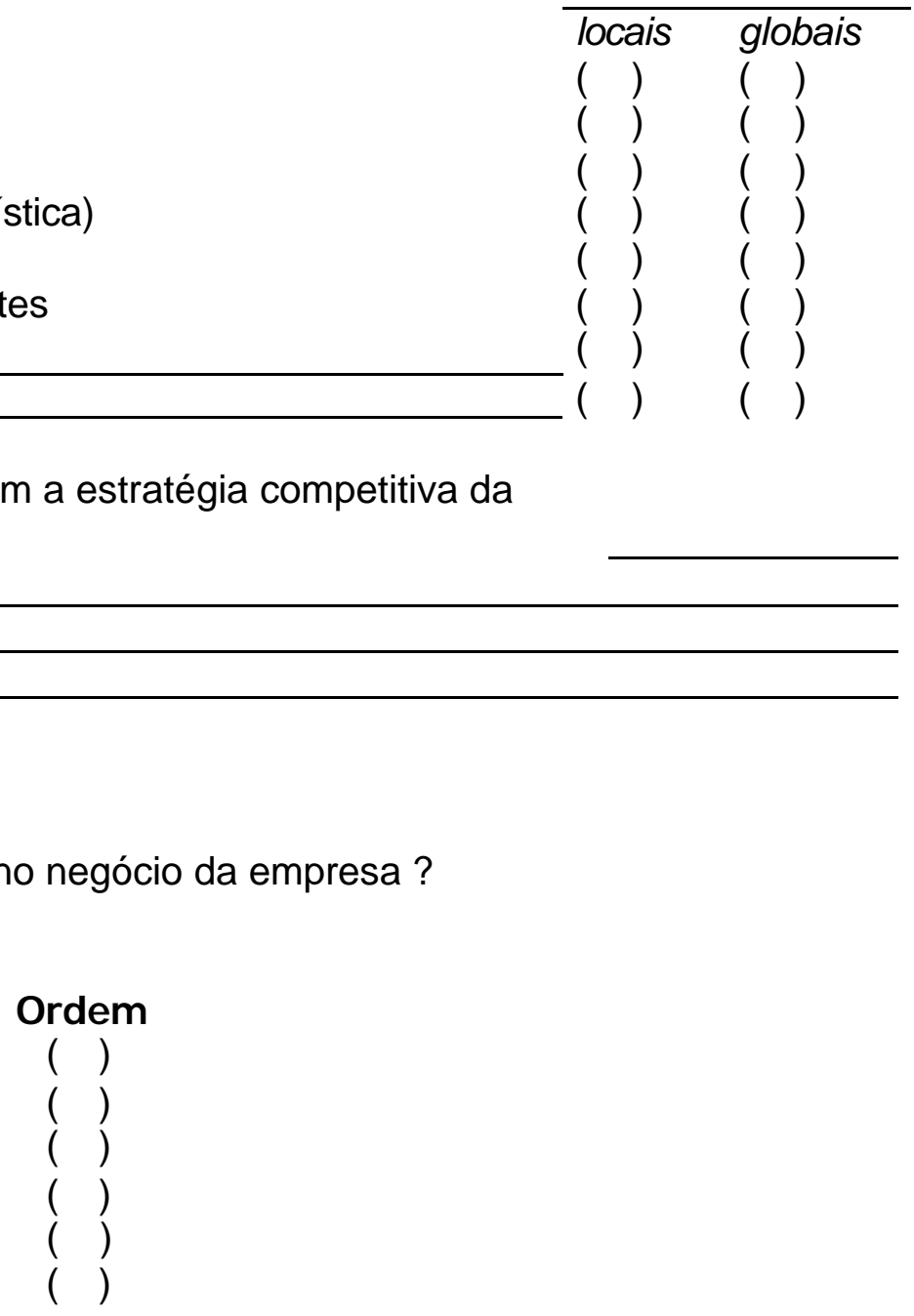

$$
\text { : }
$$




\subsection{Desenvolvimento de produtos}

Como a empresa desenvolve seus produtos?

Assinale a alternativa que melhor descreve a situação

A empresa desenvolve produtos com total independência

A empresa tem parcerias para desenvolver produtos. Que tipo ?

em conjunto com o cliente

Escritórios de design

com fornecedores de matéria prima

O produto já vem especificado pelo cliente

Totalmente, inclusive a matéria prima

Parcialmente, a empresa tem que escolher insumos e processo

Outra configuração

4.3 Investimento em P\&D

Capital investido em pesquisas internas em relação ao faturamento, no último （ ）\% ano

Investimento em licenciamentos em relação ao faturamento, no último ano

Investimento em royalties em relação ao faturamento, no último ano

Participação na receita de produtos lançados nos três últimos anos

4.4 Em relação à inovação tecnológica, como caracteriza o papel da empresa dentro da cadeia produtiva

Geradora de tecnologias (Iniciando e liderando inovações tecnológicas)

Adaptadora de tecnologias (Modificando e adaptando significativamente tecnologias geradas externamente)

Usuária de tecnologias (Utiliza tecnologias externas com pouca modificação)

\section{Gestão da Produção e Logística}

5.1 A empresa é: integrada ( ) ou especializada ( )

Razões da escolha (vantagens e desvantagens):

5.2 A empresa terceiriza operações ou funções do processo produtivo ? Sim ( ) Não ( )

Para quais produtos / estágios do processo de produção?

Razões da escolha (vantagens e desvantagens): 


\subsection{Equipamentos}

A empresa introduziu algum processo tecnologicamente novo ou aperfeiçoado nos últimos três anos?

Estes processos novos demandaram a aquisição de novos equipamentos ( ?

Equipamentos foram adquiridos, em sua maioria, no mercado local ?

Valor gasto na aquisição de novos equipamentos no último ano em relação ao faturamento no último ano

Em quanto foi ampliada a capacidade produtiva do processo para o qual esta máquina/equipamento foi adquirida(o)?

5.4 Qual o maior desafio na gestão da produção e logística?

Marque com um " $X$ " os métodos ou técnicas de gestão que a empresa utiliza. Na Segunda coluna informe se alguma dessas opções foi motivada por sugestão de clientes ou fornecedores

Gestão da qualidade

Gestão de estoques

Quick response

Outros :

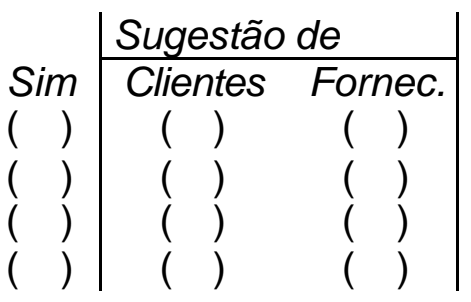

5.5 Adoção de Tecnologias de Informação para

Com clientes

Com fornecedores

ERP - Enterprise Resources Planning

EDI - Electronic Data Interchange

Portais para compra de insumos e/ou venda de produtos

Outros

5.6 Quando se considera a questão dos standards internacionais, quais são adotados pela empresa ? Houve pressão de clientes para a decisão de adotá-los ?

ISO 9.001

ISO 9.002

ISO 14.000

Outras :

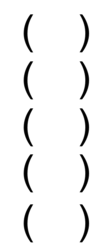

5.7 A empresa utiliza serviços externos para garantir / avalizar a qualidade de seus produtos?

Sim ( ) Não ( ) Quais ? 


\section{Marketing e vendas}

\subsection{A estratégia de mercado é:}

de massa (altos volumes produtos padronizados) ( )

de nichos (pequenos volumes produtos

diferenciados

\subsection{Como é o processo de comercialização ?}

Definido pela empresa

Definido pelo cliente

Utiliza trading company

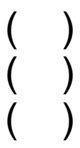

6.3 A empresa participa de eventos de promoção comercial ?

Eventos:

Feiras

Desfiles

Missões econômicas no exterior

Outros
Regionais Nacionais Internacionai

$\mathrm{S}$

()
()
()

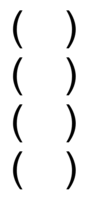

\section{Gestão de recursos humanos}

7.1 Quadro de pessoal: número total de funcionários:

\begin{tabular}{l|l|l|l|l|l}
\hline \multirow{2}{*}{ Pessoas alocadas } & \multirow{2}{*}{ No. } & \multicolumn{5}{l}{ Nível médio de escolaridade (*) } & \\
\cline { 4 - 6 } & & Pós-graduação & Nível Superior & Nível Técnico & Nível Ginasial \\
\hline Direção e gerência & & & & & \\
\hline Desenvolvimento e & & & & & \\
Engenharia & & & & & \\
\hline Marketing e vendas & & & & & \\
\hline Produção e logística & & & & & \\
\hline Finanças & & & & & \\
\hline Recursos Humanos & & & & & \\
\hline Outras & & & & & \\
\hline
\end{tabular}

$\left({ }^{*}\right)$ percentual estimado/ padrão predominante

7.2 A empresa teve alteração no número de funcionários nos últimos anos ?

Não houve alteração

Aumentou

Diminuiu

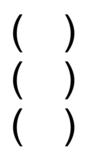

Porque ? quais as categorias mais afetadas?:

\section{Categoria} Motivo 
7.3 O nível educacional exigido para a contratação está mudando ? Para quais cargos ?

\begin{tabular}{|l|l|l|l|}
\hline Cargos & Aumentando & Diminuindo & Como o nível educacional está sendo alterado ? \\
\hline & & & \\
\hline & & & \\
\hline & & & \\
\hline & & & \\
\hline
\end{tabular}

7.4 Qual o investimento anual da empresa para o treinamento de seus funcionários ? Investimento:

$\mathrm{R}$

$\$$

\% Faturamento:

Aumentando ou diminuindo

?:

Número médio de horas /treinamento por pessoa:

7.5 Qual a categoria de funcionários que tem mais recebido treinamento nos últimos anos ? Porque?

\begin{tabular}{l|l} 
Categoria & Motivo
\end{tabular}

7.6 Remuneração

Existem sistemas de remuneração diferenciado por categorias ou grupos de empregados?

\begin{tabular}{l|l} 
Tipo de remuneração & Categorias \\
\hline $\begin{array}{l}\text { Baseado na estrutura de } \\
\text { cargos }\end{array}$ & \\
\hline Remuneração variável & \\
\hline Remuneração por & \\
competência & \\
\hline
\end{tabular}

\section{Relações institucionais}

8.1 de quais associações empresariais/comerciais ou sindicatos sua empresa participa? 
8.2 Qual tem sido o papel das associações empresariais ?

8.3 Como este papel vem sendo desempenhado ?

8.4 Quais são as relações que a empresa mantém com a esfera governamental?

8.5 Como avalia as seguintes políticas públicas ? Industrial

Comércio

Exterior

Tributária

\section{Tendências e perspectivas}

IX.1 Competitividade da indústria têxtil nacional em relação a outros mercados Assinale com um "X" as situações em que você avalia que a indústria têxtil nacional é competitiva

Produtos, segmentos e marcas

Segmentos matéria prima fiação tecelagem acabamento confecção distribuição Comercialização

Produtos Jeans T-Shirts Linha lar Outros: Em relação ao mercado ...

\begin{tabular}{|c|c|c|}
\hline Mercosul & NAFTA & $\begin{array}{c}\text { União } \\
\text { Européia }\end{array}$ \\
\hline ( ) & ( ) & ( ) \\
\hline ( ) & ( ) & ( ) \\
\hline ( ) & ( ) & ( ) \\
\hline ( ) & ( ) & ( ) \\
\hline ( ) & ( ) & ( ) \\
\hline ( ) & ( ) & ( ) \\
\hline ( ) & ( ) & ( ) \\
\hline ( ) & ( ) & ( ) \\
\hline ( ) & ( ) & ( ) \\
\hline & ( ) & ( ) \\
\hline ( ) & ( ) & ( ) \\
\hline
\end{tabular}


9.2 Qual é a perspectiva da empresa considerando os atuais acordos internacionais de comercio, especificamente o Acordo

Multifibras?:

9.32005 e a liberalização dos acordos de comércio

$9.4 \quad$ Mercado nacional

\subsection{Mercosul}

\section{$9.6 \quad \mathrm{ALCA}$}

\subsection{Mercado global}


Apendice A.2 - Questionário aplicado em Honduras

\title{
LA COMPETITIVIDAD DE LA CADENA PRODUTIVA DE LA INDUSTRIA TEXTIL Y DEL VESTIDO HONDURENA ${ }^{62}$
}

\author{
PROYECTO DE INVESTIGACION ACADEMICA
}

\begin{abstract}
El objetivo de este cuestionario es recolectar informaciones para realizar un análisis de la competitividad de la cadena productiva de las industrias textil y del vestido en Honduras y en Brasil de acuerdo al enfoque de Cadenas Productivas Globales, y del Progreso Industrial (Industrial Upgrading) generado por estas industrias. De forma sintética son estas las principales temas de mi tesis de Doctorado en Ingeniería Producción en la Universidad de Sao Paulo, Brasil.

Todas las informaciones serán manejadas en carácter confidencial y no se publicaran los nombres de las empresas y de las personas que respondan el cuestionario.

Las personas y empresas que respondan el cuestionario recibirán una copia magnética del resultado final de la investigación.

Para cualquier información adicional por favor contactar a Juan Ricardo Cruz Moreira: juan.moreira@poli.usp.br
\end{abstract}

\section{Empresa:}

Entrevistado:

Cargo:

Tiempo en la empresa: (años)

\section{Caracterización de la empresa}

I.1 Por favor relate brevemente la historia de la empresa (Fundadores, año de fundación, lugar y principal actividad inicial, numero de empleados, capital inicial, etc.):

\section{I.2 Estructura de capital}

\begin{tabular}{|c|c|c|c|c|}
\hline $100 \%$ Nacional & $>50 \%$ Nacional & $<50 \%$ Nacional & $100 \%$ Internacional & Joint venture \\
\hline & & & & \\
\hline
\end{tabular}

I.3 La gerencia de la empresa es realizada por:

Administradores profesionales contratados

Personas de la familia

I.4 ¿Trabaja la empresa bajo acuerdos de maquila de exportación?: Sí ( ) No ( ) otros ( )

I.5 Tipo de manufactura - posición en la cadena - nivel de integración

\begin{tabular}{|l|l|l|l|l|l|l|l|l|l|}
\hline Fibras & Hilos & $\begin{array}{l}\text { Telas } \\
\text { planas (telar } \\
\text { de calada) }\end{array}$ & $\begin{array}{l}\text { Artículos/ } \\
\text { telas de } \\
\text { punto }\end{array}$ & Corte & Confección & Distribución & Comercialización & $\begin{array}{l}\text { Otros } \\
\text { insumos } \\
\text { productivos }\end{array}$ \\
\cline { 1 - 8 } Alg. & Sint & & & & & & & \\
\hline
\end{tabular}

I.6 Tipo de Nicho de Mercado final al que se destina su producto / servicio:

\begin{tabular}{|l|l|l|l|l|l|l|l|l|l|l|l|}
\hline $\begin{array}{l}\text { Ropa } \\
\text { Fem. }\end{array}$ & $\begin{array}{l}\text { Ropa } \\
\text { Masc }\end{array}$ & $\begin{array}{l}\text { Ropa } \\
\text { Infant }\end{array}$ & $\begin{array}{l}\text { Jeans } \\
\text { wear }\end{array}$ & $\begin{array}{l}\text { Ropas } \\
\text { Deportiv }\end{array}$ & $\begin{array}{l}\text { R. int. } \\
\text { Masc }\end{array}$ & $\begin{array}{l}\text { R. Int. } \\
\text { Fem }\end{array}$ & $\begin{array}{l}\text { Media } \\
\text { Fem. }\end{array}$ & Calcetín & $\begin{array}{l}\text { Productos p/ } \\
\text { Cama y Mesa }\end{array}$ & $\begin{array}{l}\text { Prod. Tela } \\
\text { Toalla }\end{array}$ & \begin{tabular}{l} 
Otros \\
\hline
\end{tabular} \\
\hline
\end{tabular}

\footnotetext{
${ }^{62}$ Juan Ricardo Cruz Moreira , Hondureño ID: 0801-1963-06552
} 
I.7 Evolución de la capacidad productiva instalada y destino de la producción

\begin{tabular}{|c|c|c|c|c|c|c|c|}
\hline \multirow[t]{2}{*}{ Año } & \multirow{2}{*}{$\begin{array}{l}\text { Capacidad instalada } \\
\text { (unidades* /año) }\end{array}$} & \multirow{2}{*}{$\begin{array}{l}\text { No. de } \\
\text { plantas }\end{array}$} & \multirow{2}{*}{$\begin{array}{l}\text { Producción } \\
\text { Efectiva }\end{array}$} & \multicolumn{2}{|c|}{ Localización } & \multicolumn{2}{|c|}{ Destino de la producción (\%) } \\
\hline & & & & $\overline{Z P E}$ & Otro & Nacional & Exportación \\
\hline 1980 & & & & & & & \\
\hline 1989 & & & & & & & \\
\hline 1990 & & & & & & & \\
\hline 1995 & & & & & & & \\
\hline 2000 & & & & & & & \\
\hline
\end{tabular}

* Por favor indique la unidad: Toneladas ( ) metros ( ) yardas ( ) piezas ( ) otra

\section{Mercados y estrategias}

II.1 Tipo de producto:

Ropa Standard ( ) Ropa de fashion-design( )

\section{II.2 Formas de comercialización}

\begin{tabular}{|l|l|l|l|}
\hline \multicolumn{1}{|c|}{ Canales de comercialización } & Mercado nacional & Exportación directa & Exportación indirecta \\
\hline Consumidor final sin marca & & & \\
\hline Consumidor final con marca propia & & & \\
\hline Redes propias de tiendas & & & \\
\hline Reconocidas marcas nacionales & & & \\
\hline Reconocidas marcas extranjeras & & & \\
\hline Redes de distribución nacionales & & & \\
\hline Redes de distribución extranjeras & & & \\
\hline Brokers / Trading Companies & & & \\
\hline Franquicias & & & \\
\hline ¿Otras?, ¿Cuales? & & & \\
\hline
\end{tabular}

II.3 Principales mercados a los que exportó la empresa en los 3 últimos años

\begin{tabular}{|l|l|l|} 
Año & Destino & \% Producción \\
\hline 2001 & & \\
\hline 2000 & & \\
\hline 1999 & & \\
\hline
\end{tabular}

Definido por la empresa ( )

Definido por el cliente ( ) II.4 El Proceso de comercialización es:

\section{II.5 Participa la empresa de eventos de promoción comercial ?}

\begin{tabular}{|l|l|l|l|}
\hline Eventos & Nacionales & Regionales & Internacionales \\
\hline Ferias, exposiciones & & & \\
\hline Misiones económicas al exterior & & & \\
\hline Otros: & & & \\
\hline
\end{tabular}

\section{Estrategia competitiva}

\section{III.1 ¿Cual es la principal estrategia competitiva de la empresa? (señale una)}

Excelencia operacional: Productos estandarizados, optimización da relación calidad / precio Innovaciones constantes en los productos

Orientación hacia el cliente: Conocimiento profundo de las necesidades de clientes específicos 


\section{III.2 Factores de la capacidad competitiva da empresa}

Asigne un valor de la siguiente manera:

\begin{tabular}{|l|l|}
\hline $\mathbf{1}$ - & Muy importante - Crítico \\
\hline $\mathbf{2}$ - & Relativamente importante \\
\hline $\mathbf{3}$ - & Poco importante - Irrelevante \\
\hline
\end{tabular}

\begin{tabular}{|l|l|}
\hline Factor & Importancia del factor \\
\hline Capacidad de coordinar la cadena de suplimentos & \\
\hline Capacidad de crear y coordinar parcerias o alianzas estratégicas & \\
\hline Calidad de la materia prima & \\
\hline Diversidad de la materia prima & \\
\hline Costo de la mano de obra & \\
\hline Calidad del equipo y maquinaria & \\
\hline Innovación en los productos & \\
\hline Innovación en las formas de comercialización & \\
\hline Localización de plantas para reducir costos y obtener subsidios & \\
\hline Localización de plantas para optimizar los costos de logística & \\
\hline Otros: Recursos humanos son la base del conocimiento en esta industria & \\
\hline
\end{tabular}

\section{III.4 Principales Competidores (empresas y países)}

Nacionales

\section{Internacionales \\ Realiza Benchmarking la empresa? Sí ( ) No ( ) \\ Como?}

\section{III.5 Principales suministradores}

\begin{tabular}{|l|l|l|}
\hline Insumo & Nacional & Extranjero (Empresas y países) \\
\hline Materia prima & & \\
\hline Equipo y Máq. & & \\
\hline Tecnología y & & \\
\hline Conocimiento & & \\
\hline
\end{tabular}

\section{Se trabaja con Taiwán para la instilación de un centro de adiestramiento tecnologíco}

\section{6 Cómo se caracterizan las relaciones con las empresas en la cadena productiva?} (marcar $S$ e $N)$

\begin{tabular}{|l|l|l|}
\hline Tipo de relación & Clientes & Suministradores \\
\hline Informales & & \\
\hline Temporales & & \\
\hline Contractuales & & \\
\hline Alianzas Estratégicas & & \\
\hline
\end{tabular}




\section{COMPETITIVIDAD}

\section{IV.1 Presencia de Ventajas Competitivas}

Por favor responda el cuadro abajo utilizando los valores de la siguiente tabla:

\begin{tabular}{|c|l|}
\hline $\mathbf{1}$ & Si la empresa TIENE ALTA Ventaja Competitiva en este aspecto \\
\hline $\mathbf{2}$ & Si la empresa TIENE BAJA Ventaja Competitiva en este aspecto \\
\hline $\mathbf{3}$ & Si la empresa NO TIENE Ventaja Competitiva en este aspecto \\
\hline
\end{tabular}

\begin{tabular}{|c|c|c|c|}
\hline \multirow[t]{2}{*}{ Ventajas Competitivas (Intrínsecamente relacionadas a la empresa) } & \multicolumn{3}{|c|}{$\begin{array}{l}\text { Con relación a los } \\
\text { competidores... }\end{array}$} \\
\hline & Nac. & Región & Globales \\
\hline \multicolumn{4}{|l|}{ Conocimiento de los mercados } \\
\hline \multicolumn{4}{|l|}{ Escala de producción / modernidad del equipo y maquinaria } \\
\hline \multicolumn{4}{|l|}{ Capacidad de gerencia } \\
\hline \multicolumn{4}{|l|}{ Capacidad de design } \\
\hline \multicolumn{4}{|l|}{ Forma de comercialización } \\
\hline \multicolumn{4}{|l|}{ Articulación en la cadena productiva (suministro y comercialización) } \\
\hline \multicolumn{4}{|l|}{ Marca reconocida } \\
\hline \multicolumn{4}{|l|}{ Capacidad de elaborar productos como "paquete completo" (fullpackage) } \\
\hline Otras: & & & \\
\hline
\end{tabular}

\section{IV.2 Desventajas competitivas}

Por favor responda el cuadro abajo utilizando los valores de la siguiente tabla:

\begin{tabular}{|c|l|}
\hline $\mathbf{1}$ & Si la empresa TIENE ALTA Desventaja Competitiva en este aspecto \\
\hline $\mathbf{2}$ & Si la empresa TIENE BAJA Desventaja Competitiva en este aspecto \\
\hline $\mathbf{3}$ & Si la empresa NO TIENE Desventaja Competitiva en este aspecto \\
\hline
\end{tabular}

\begin{tabular}{|l|l|l|}
\hline $\begin{array}{l}\text { Desventajas Competitivas (Relacionadas con el ambiente en que la } \\
\text { empresa opera) }\end{array}$ & \multicolumn{2}{l|}{$\begin{array}{l}\text { Con relación a los } \\
\text { competidores ... }\end{array}$} \\
\hline & Nac. & \multicolumn{1}{c|}{ Globales } \\
\hline Precio de los insumos & & \\
\hline Mecanismos de crédito y financiamiento & & \\
\hline Costo del capital para la inversión & & \\
\hline Calificación de los recursos humanos existentes & & \\
\hline Localización (Con relación a los costos de mano de obra) & \\
\hline Localización (Con relación a los costos de logística) & \\
\hline Tributación & & \\
\hline
\end{tabular}

\section{IV.3 Competitividad de la industria nacional con relación a otros mercados / países competidores}

Responda con una " $X$ " las situaciones en que considere que la industria textil y del vestido nacional es competitiva

\begin{tabular}{|c|c|c|c|c|c|c|c|c|c|}
\hline \multirow{2}{*}{\multicolumn{2}{|c|}{ Productos y segmentos }} & \multicolumn{8}{|c|}{ Con relación al mercado ... } \\
\hline & & $\begin{array}{c}\text { Centro } \\
\text { América }\end{array}$ & México & NAFTA & Caribe & $\begin{array}{c}\text { Sur } \\
\text { América }\end{array}$ & $\begin{array}{c}\text { MERCO } \\
\text { SUR }\end{array}$ & Europa & Asia \\
\hline \multirow[t]{6}{*}{ Segmento } & Fibras & & & & & & & & \\
\hline & Hilos & & & & & & & & \\
\hline & Telas & & & & & & & & \\
\hline & Confección & & & & & & & & \\
\hline & Distribución & & & & & & & & \\
\hline & Comercialización & & & & & & & & \\
\hline \multirow[t]{5}{*}{ Productos } & Jeans & & & & & & & & \\
\hline & T-Shirts & & & & & & & & \\
\hline & Ropa Int. Masc. & & & & & & & & \\
\hline & Ropa Int. Fem. & & & & & & & & \\
\hline & Fem. Fashion & & & & & & & & \\
\hline
\end{tabular}




\begin{tabular}{|l|l|l|l|l|l|l|l|l|}
\hline & Otros & & & & & & & \\
\hline
\end{tabular}

\section{IV.4 Estructura y organización}

¿Cuál es la función crítica para el éxito en el ramo de negocio de su empresa? (Colocar en orden de importancia siendo 1 el mas importante)

\begin{tabular}{|l|l|}
\hline Función & Orden \\
\hline Marketing e Ventas & \\
\hline Producción & \\
\hline Desarrollo / design de productos & \\
\hline Finanzas & \\
\hline Otra: & \\
\hline
\end{tabular}

\section{IV.5 Design / desarrollo de productos}

¿Cómo a empresa crea o desarrolla sus productos? Marque la alternativa que mejor corresponde La empresa desarrolla sus productos con total independencia:

La empresa realiza parcerias / alianzas para desarrollar sus productos. ¿De que tipo?

En conjunto con el cliente

Consultores especializados en design

Con los suministradores de materia prima

Con los suministradores del equipo

El producto ya viene especificado por el cliente

Totalmente, inclusive la materia prima

Parcialmente, la empresa es responsable por la selección de materias primas y proceso

¿Otra configuración? Por favor descríbala a seguir:

\section{IV.6 Inversión en investigación y desarrollo I \& D}

\begin{tabular}{|l|c|}
\hline Capital invertido en investigación interna con relación al facturamiento, en el último año & $\%$ \\
\hline inversión en licencias con relación al facturamiento, en el último año & $\%$ \\
\hline inversión en royalties con relación al facturamiento, en el ultimo año & $\%$ \\
\hline inversión en tecnología de información y comunicación en el ultimo año con relación al fact. & $\%$ \\
\hline Participación en los resultados de la empresa de productos lanzados en los 3 últimos años & $\%$ \\
\hline
\end{tabular}

V. Gerencia de la producción y la logística

V.1 La empresa es: integrada () o especializada ( )

¿En que etapas de la cadena productiva?:

Motivos para la selección de esta estrategia (ventajas y desventajas):

V.2 ¿Subcontrata la empresa, otras compañías para realizar operaciones especificas, procesos productivos, productos o servicios? Sí ( ) No ( )

¿Para que productos / etapas de la producción? 


\section{V.3 Indicadores de actualización tecnológica}

\begin{tabular}{|l|c|}
\hline Equipo y maquinaria & Sí \\
\hline ¿Su empresa introdujo algún proceso tecnológicamente nuevo o lo perfeccionó en los & \\
últimos tres años? & \\
\hline ¿Estos procesos nuevos requirieron adquisición de equipo nuevo ? & \% \\
\hline \% del facturamiento del ultimo año, invertido en la adquisición de equipo nuevo & $\%$ \\
\hline ¿En cuanto fue ampliada la capacidad productiva con esa adquisición /modernización? & \\
\hline
\end{tabular}

¿Cual es la procedencia de la mayoría del equipo? Por favor especifique:

\section{V.4 Instalaciones productivas}

La empresa ha invertido en la construcción / adquisición / alquiler de edificios nuevos o ampliaciones de las instalaciones de manufactura? Si ( ) No ( )

Esta inversión se realizo en los últimos:

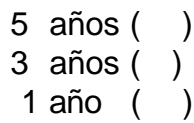

\section{V.5 Gerencia de la producción y logística}

Marque con una " $X$ " los métodos o técnicas de gerencia que la empresa utiliza.

En la segunda columna informe si alguna de esas opciones fue motivada por sugerencia de clientes o suministradores

\begin{tabular}{|c|c|c|c|}
\hline \multirow{2}{*}{$\begin{array}{l}\text { Métodos y técnicas de gerencia de la producción y logística } \\
\text { actualmente en uso en la empresa }\end{array}$} & \multicolumn{2}{|c|}{$\begin{array}{l}\text { Si en uso, de quien fue la } \\
\text { sugerencia }\end{array}$} & \\
\hline & Clientes & Suminist. & \\
\hline \multicolumn{4}{|l|}{ Justa-In-Time (En el Momento Justo) } \\
\hline \multicolumn{4}{|l|}{ CEP - Control Estadístico de Procesos } \\
\hline \multicolumn{4}{|l|}{ Kanban } \\
\hline \multicolumn{4}{|l|}{5 'S' } \\
\hline \multicolumn{4}{|l|}{ Trabajo en Grupo } \\
\hline \multicolumn{4}{|l|}{ Células de Producción semi-autónoma } \\
\hline \multicolumn{4}{|l|}{ Ingeniería Simultanea } \\
\hline \multicolumn{4}{|l|}{ Reducción de niveles jerárquicos } \\
\hline \multicolumn{4}{|l|}{$\begin{array}{l}\text { Tele-trabajo (equipos virtuales, entre plantas o con los clientes/ } \\
\text { suministradores) }\end{array}$} \\
\hline \multicolumn{4}{|l|}{ Home-office (personas trabajando en casa) } \\
\hline \multicolumn{4}{|l|}{ Jornada flexible de trabajo } \\
\hline \multicolumn{4}{|l|}{ Banco de horas } \\
\hline \multicolumn{4}{|l|}{ Jornada de tiempo parcial } \\
\hline \multicolumn{4}{|l|}{ Reducción del número de suministradores } \\
\hline \multicolumn{4}{|l|}{ Contratación de consultores para la mejoría del sistema productivo } \\
\hline \multicolumn{4}{|l|}{ Contratación de consultores para el desarrollo de nuevos productos } \\
\hline \multirow{2}{*}{\multicolumn{2}{|c|}{$\begin{array}{l}\text { Tecnologías de información y comunicación utilizadas para la gerencia de la } \\
\text { producción y logística en la empresa }\end{array}$}} & \multicolumn{2}{|c|}{$\begin{array}{l}\text { Si en uso, quien lo } \\
\text { sugirió }\end{array}$} \\
\hline & & Clientes & Suminist. \\
\hline \multicolumn{4}{|c|}{ Sistema interno de informaciones interpersonales (Intranet) } \\
\hline \multicolumn{4}{|c|}{ Proyectos o alianzas visando la mejoría de infraestructura de telecomunicaciones } \\
\hline \multicolumn{2}{|c|}{$\begin{array}{l}\text { Implantación de páginas de Internet para la comercialización de productos o } \\
\text { servicios } \\
\text { Implantación de página de Internet para divulgación de productos y para la relación } \\
\text { con los clientes } \\
\text { Uso de sistemas para integración de as informaciones de las distintas áreas de la } \\
\text { empresa (Ej.: SAP, MICROSIGA, etc) }\end{array}$} & & \\
\hline \multicolumn{2}{|c|}{ Por favor especifique otras, si pertinente: } & & \\
\hline
\end{tabular}




\begin{tabular}{|c|c|c|c|c|c|}
\hline \multicolumn{4}{|c|}{$\begin{array}{l}\text { Tecnologías de información y comunicación utilizadas para e- } \\
\text { commerce, comercio virtual por medio dela Internet }\end{array}$} & \multicolumn{2}{|c|}{$\begin{array}{l}\text { Si en uso, de quien } \\
\text { fue la sugerencia }\end{array}$} \\
\hline Sisten & a utilizado para: & $\begin{array}{l}\text { Comprar } \\
\text { insumos }\end{array}$ & $\begin{array}{l}\text { Venta de } \\
\text { productos }\end{array}$ & Clientes & Suminist \\
\hline \multicolumn{6}{|c|}{ EDI - Electronic Data Interchange } \\
\hline \multicolumn{6}{|c|}{$\begin{array}{l}\text { Insumos a través de la Internet } \\
\text { (Global Sourcing) }\end{array}$} \\
\hline \multicolumn{6}{|c|}{$\begin{array}{l}\text { E-marketplaces, sites de los suministradores / } \\
\text { clientes o de brokers especializados }\end{array}$} \\
\hline Otros: & & & & & \\
\hline
\end{tabular}

\section{CERTIFICACIONES}

¿La empresa es acreditada con algún tipo de certificación? Marque con una $\mathrm{X}$ en al columna de la derecha.

\begin{tabular}{|l|l|}
\hline ISO 9.001 & \\
\hline ISO 9.002 & \\
\hline ISO 14.000 & \\
\hline Otras: & \\
\hline & \\
\hline
\end{tabular}

¿Utiliza la empresa, servicios externos para garantizar / certificar la calidad de sus productos?

Sí ( ) No ( )

VIII. Gerencia de recursos humanos

VIII.1 Cuadro de empleados: Número total:

\begin{tabular}{|l|l|l|l|l|l|l|}
\hline \multirow{2}{*}{ Departamento / Unidad } & \multirow{2}{*}{ Número } & \multicolumn{5}{|l|}{ Nivel pro medio de escolaridad predominante } \\
\cline { 5 - 7 } & & $\begin{array}{l}\text { Post- } \\
\text { graduación }\end{array}$ & $\begin{array}{l}\text { nivel } \\
\text { Universitario }\end{array}$ & $\begin{array}{l}\text { nivel } \\
\text { Técnico }\end{array}$ & $\begin{array}{l}\text { nivel } \\
\text { Secundario }\end{array}$ & $\begin{array}{l}\text { Educ. } \\
\text { Primaria }\end{array}$ \\
\hline Dirección y gerencia & & & & & & \\
\hline Desarrollo e Ingeniería & & & & & & \\
\hline Marketing y ventas & & & & & & \\
\hline Finanzas & & & & & & \\
\hline Producción y logística & & & & & & \\
\hline Recursos Humanos & & & & & & \\
\hline Otras & & & & & & \\
\hline
\end{tabular}

VIII.2 ¿Hubo alteración del número de empleados en la empresa en los últimos años ?

No hubo alteración

Aumento

Disminuyo

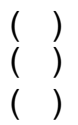

¿Porque? ¿Cuales fueron las categorías más afectadas ?

\begin{tabular}{l|l} 
Categoría & Motivo \\
\hline & \\
\hline &
\end{tabular}

VIII.3 ¿Ha cambiado el nivel educacional exigido para nuevas contrataciones? ¿Para que cargos ? Cargos / Tipo de cargo Aumentando Diminuyendo 
VIII.4 ¿Cual es el monto de la inversión anual destinado por la empresa para el entrenamiento de sus empleados?

inversión:

$\%$ del Facturamento:

Aumentando o disminuyendo ?:

US\$

Promedio de horas /año de entrenamiento por empleado:

VIII.5 Cual es la categoría de empleados que más ha recibido entrenamiento en los últimos años ? Porque?

\begin{tabular}{l|l} 
Categoría & Motivo \\
\hline & \\
\hline & \\
\hline & \\
\hline & \\
\hline
\end{tabular}

\section{VIII.7 Sueldos e salarios}

¿Existen diferentes sistemas de sueldos y salarios por categorías o grupos de empleados?

Tipo de sueldo /salario

Se basa en la estructura tradicional de cargos y salarios

Sueldos variables

Remuneración por competencias

IX. Relaciones institucionales

IX.1 Marque con " $X$ " las instituciones de las cuales su empresa participa

\begin{tabular}{|l|c|}
\hline Asociación Empresarial: & Participa \\
\hline AHMA & \\
\hline Cámara de comercio e Industrias local & \\
\hline AMCHAM & \\
\hline Otras: & \\
\hline & \\
\hline
\end{tabular}

IX.2 ¿Cual ha sido el papel de estas asociaciones empresariales ?

IX.4 Cuales son las relaciones que la empresa tiene con la esfera gubernamental?

IX. ¿Cómo evalúa las siguientes políticas públicas ?

Industrial:

Comercio Exterior:

Tributaria

Salarial : 
X. Tendencias e perspectivas

X.1 ¿Cuales son las perspectivas de la empresa considerando los actuales acuerdos internacionales de comercio, específicamente el Acuerdo Multifibras y el ATC y la liberación del mercado en el 2005?

X.3 ¿Cuales son las perspectivas de la industria para el mercado nacional:

X.4 ¿Con relación al TLC México y al NAFTA por completo?

X.5 ¿Con relación a Centroamérica?

X.6 ¿Con relación a los países de la cuenca del caribe?

X.7 ¿Con relación al ALCA?

X.8 ¿Con relación al mercado global? 
